UNIVERSIDADE DE SÃO PAULO - USP

FACULDADE DE EDUCAÇÃO - FE

LUCIANE SILVA BAIÃO DE ALBUQUERQUE

\title{
A COMUNICAÇÃO ESCRITA DA CIÊNCIA NO ESPAÇO ESCOLAR
}

São Paulo 


\section{A COMUNICAÇÃO ESCRITA DA CIÊNCIA NO ESPAÇO ESCOLAR}

Dissertação apresentada à Faculdade de Educação da Universidade de São Paulo para obtenção do título de Mestre em Educação.

Linha de Pesquisa: Ensino de Ciências e Matemática.

Orientador Prof. Dr. Agnaldo Arroio

São Paulo 
AUTORIZO A REPRODUÇÃO E DIVULGAÇÃO TOTAL OU PARCIAL DESTE TRABALHO, POR QUALQUER MEIO CONVENCIONAL OU ELETRÔNICO, PARA FINS DE ESTUDO E PESQUISA, DESDE QUE CITADA A FONTE.

Catalogação na Publicação

Serviço de Biblioteca e Documentação

Faculdade de Educação da Universidade de São Paulo

375.2 Albuquerque, Luciane Silva Baião de

A345c A comunicação escrita da ciência no espaço escolar / Luciane Silva Baião de Albuquerque; orientação Agnaldo Arroio. São Paulo: s.n., 2010

$225 \mathrm{p} ; \mathrm{CD}-\mathrm{ROM}$.

Dissertação (Mestrado - Programa de Pós-Graduação em

Educação. Área de Concentração: Ensino de Ciências e Matemática) - Faculdade de Educação da Universidade de São Paulo.

1. Comunicação escrita 2. Escrita 3. Linguagem científica 4. Domínio 5. Internalização 6. Ensino médio I. Arroio, Agnaldo, orient. 
Luciane Silva Baião de Albuquerque

\section{A COMUNICAÇÃO ESCRITA DA CIÊNCIA NO ESPAÇO ESCOLAR}

Dissertação apresentada à Faculdade de Educação da Universidade de São Paulo para obtenção do título de Mestre em Educação.

Linha de Pesquisa: Ensino de Ciências e Matemática.

Orientador Prof. Dr. Agnaldo Arroio

Aprovada em:

\section{Banca Examinadora:}

Prof. Dr.:

Instituição: Assinatura:

Prof. Dr.:

Instituição: Assinatura:

Prof. Dr.:

Instituição: Assinatura: 


\section{AGRADECIMENTOS}

Agradeço a todos que contribuíram direta ou indiretamente para a realização deste estudo, em especial:

Ao Prof. Dr. Agnaldo Arroio, que me orientou com toda paciência e atenção durante esses anos de mestrado e incentivou meu trabalho nos momentos mais complicados dessa jornada.

À colega Glades Miquelina, pela inestimável ajuda em meu trabalho, contribuindo com idéias valiosas, e pelo incentivo durante a estruturação do trabalho.

Aos estudantes que participaram do grupo de Pré-Iniciação Científica e foram essenciais à minha investigação.

À Faculdade de Educação da Universidade de São Paulo, pela oportunidade de realização do curso de Mestrado.

À minha família e às minhas amigas, que me incentivaram com palavras de apoio.

Ao meu filho amado Nickolas, que se comportou de modo exemplar durante a elaboração do trabalho, permitindo que eu o terminasse a tempo.

Ao meu marido e companheiro Douglas, que me incentivou e apoiou nessa árdua jornada.

A Deus, que me deu forças para ir adiante durante os momentos mais difíceis dessa caminhada. 


\section{RESUMO}

ALBUQUERQUE, Luciane Silva Baião, A comunicação escrita da ciência no espaço escolar. 2010, 225f. Dissertação (Mestrado) - Faculdade de Educação, Universidade de São Paulo (USP), São Paulo, 2010.

Neste estudo investigamos de que forma os alunos do Ensino Médio, participantes de um grupo de pré-iniciação científica, podem se apropriar das ferramentas necessárias à elaboração de artigos de divulgação científica. Nesse processo, tentamos visualizar como se deu a internalização dos conceitos e a absorção da linguagem científica e entender as possíveis aproximações com a educação científica, especificamente no aspecto da produção escrita de artigos. Para estudar esse processo, desenvolvemos uma seqüência de atividades para que pudessem construir o conhecimento e, ao mesmo tempo, transmiti-lo por meio da escrita de artigos. Também utilizamos questionários para conhecê-los melhor e exibimos um filme para que os estudantes pudessem entender os modos como a divulgação científica aparecia na mídia. Para responder à nossa questão, foram utilizados como dados potenciais os artigos escritos individualmente pelos estudantes no decorrer de um ano. A análise dos dados revelou um tímido domínio das ferramentas culturais, porém sem apropriação das mesmas, já que nossos alunos somente reproduziram o que lhes foi passado.

Palavras-chave: pré-iniciação científica, divulgação científica, escrita, domínio e apropriação, internalização 


\section{ABSTRACT}

ALBUQUERQUE, Luciane Silva Baião, Science writing communication on school environment. 2010, 225f. Dissertation (Mastering) - Faculdade de Educação, Universidade de São Paulo (USP), São Paulo, 2010.

In this study we investigated how high school students, who participated to a group of scientific initiation program, might borrow some tools that are considered relevant to write science communication texts. In this process we tried to comprehend how internalization of concepts and scientific language happened and understand how the approximation to the scientific education was possible in relation to the writing of articles mainly. We developed a series of activities to study this process in a way that they might help to build the knowledge and transmit it simultaneously using articles written by them. Also, we used some questionnaires in order to know better our group and their colleagues' opinions and we showed a movie to them in order to they could recognize the scientific communication on the media. In order to answer our research problem, written articles which were done by our group were used as potential data during the study. The data analysis revealed us a little domain of cultural tools and no borrowing to them. It probably happened due to our students reproduced the instructions received during the study only.

Keywords: scientific initiation, science communication, writing, domain and borrowing, internalization 


\section{LISTA DE SIGLAS}

CSI

DNA

DVD

MP3

PIC

TV
Crime Scene Investigation

ADN (ácido desoxirribonucléico)

Digital Video Disc - Disco de Vídeo Digital

MPEG-1/2 Audio Layer 3

Pré-iniciação científica

Televisão 
LISTA DE TABELAS

Tabela 1

Resumo das atividades realizadas no estudo 


\section{LISTA DE ANEXOS}

Anexo I

Anexo II

Anexo III

Anexo IV

Anexo V

Anexo VI

Anexo VII

Anexo VIII
Perfil dos alunos do grupo de PIC

Questionário aplicado ao grupo de PIC na Faculdade de Educação da USP

$1^{a}$ fase de dados: questionário aplicado em 56 salas (Ensino Fundamental II e Ensino Médio) da Escola Estadual Professora Hadla Feres

$2^{\mathrm{a}}$ fase de dados: questionário sobre o filme "Gattaca - Experiência Genética" com respostas dos alunos envolvidos no projeto

$3^{\mathrm{a}}$ fase de dados: redação de um artigo de divulgação científica tendo como base o tópico "DNA"

$4^{\text {a }}$ fase de dados: redação de um artigo de divulgação científica tendo como base uma entrevista a um profissional da área de genética

$5^{\text {a }}$ fase de dados: redação de um artigo de divulgação científica com temas escolhidos pelos próprios alunos e questionário preenchido por eles para fins de avaliação de domínio e/ou apropriação de ferramenta

$6^{\text {a }}$ fase de dados: domínio das ferramentas necessárias para a elaboração de um artigo e relatório final contendo a avaliação dos alunos sobre seu desempenho no projeto, principalmente em relação ao ato de transferir a ferramenta para outros alunos 


\section{SUMÁRIO}

$\begin{array}{ll}\text { 1. INTRODUÇÃO } & 13\end{array}$

$\begin{array}{lll}1.1 & \text { Justificativa } & 13\end{array}$

$\begin{array}{lll}1.2 & \text { O papel da ciência na escola } & 14\end{array}$

$\begin{array}{lll}1.3 & \text { O uso de textos de divulgação científica no ensino de ciências } & 16\end{array}$

$\begin{array}{lll}1.4 & \text { Textos científicos e formação crítica } & 19\end{array}$

$\begin{array}{lll}1.5 & \text { Pré-iniciação científica } & 22\end{array}$

1.6 Linguagem didática x divulgação científica 23

$\begin{array}{lll}1.7 & \text { Linguagem científica } & 25\end{array}$

$\begin{array}{lr}\text { 2. OBJETIVOS } & 27\end{array}$

3. REFERENCIAL TEÓRICO 28

4. METODOLOGIA DE ENSINO 33

4.1 O programa de Pré-Iniciação Científica 33

$\begin{array}{lll}4.2 & \text { Sujeitos da pesquisa } & 33\end{array}$

$\begin{array}{lll}4.3 & \text { Perfil dos sujeitos da pesquisa } & 34\end{array}$

$\begin{array}{lll}4.4 & \text { A proposta } & 35\end{array}$

$\begin{array}{lll}\text { 4.4.1 } & \text { Fase I } & 35\end{array}$

$\begin{array}{lll}\text { 4.4.2. } & \text { Fase II } & 38\end{array}$

$\begin{array}{lll}4.4 .3 & \text { Fase III } & 40\end{array}$

4.4.4. Fase IV 41

$\begin{array}{lll}4.4 .5 & \text { Fase V }\end{array}$

4.4.6. Fase VI 45

5. METODOLOGIA DE PESQUISA 49

$\begin{array}{lll}5.1 & \text { Dados } & 50\end{array}$

5.2 Aplicação da proposta $\quad 50$

5.3 Coleta dos dados $\quad 52$

6. RESULTADOS E DISCUSSÃO 54

6.1. Fase I 54

6.2 Fase II 56

$\begin{array}{lll}6.3 & \text { Fase III } & 60\end{array}$

6.4 Fase IV 63

$\begin{array}{lll}6.5 & \text { Fase V } & 69\end{array}$ 
$6.6 \quad$ Fase VI

7. CONSIDERAÇÕES FINAIS

8. REFERÊNCIAS BIBLIOGRÁFICAS 


\section{INTRODUÇÃO}

\subsection{Justificativa}

A palavra "comunicar" significa, segundo Holanda (2000), ato ou efeito de emitir, transmitir e receber mensagens por meio de métodos e/ou processos convencionados, quer através da linguagem falada ou escrita, quer de outros sinais, signos ou símbolos. Quando as pessoas se comunicam, elas compartilham informações de todo tipo: emoções, idéias, conceitos, advertências, necessidades, ordens etc. A palavra "comunicar" significa também "fazer saber, participar, propagar-se, transmitirse".

Considerando essa definição denotativa, entendemos que os seres humanos entendem os fatos a seu redor, segundo seu nível de construção de pensamento, porém os comunica de modos diferentes devido ao momento evolutivo em que se encontra. $\mathrm{E}$ isso não é muito diverso quando se trata do processo de aquisição da escrita e da produção de texto. Além disso, partimos do pressuposto que os indivíduos passam por situações de aprendizagem diferentes quando em contato com a escrita, o que sugere uma produção de texto com caráter diferenciado de acordo com seu nível de interação com o objeto de conhecimento que é, em nossa pesquisa, o uso da linguagem escrita.

A escrita de textos informativos como forma de ensinar e aprender ciências é constantemente considerado um desafio pelos professores, principalmente os da área científica. Embora inseridos em um mundo repleto de informações, muitas vezes pode ser notável o distanciamento entre os indivíduos e essas formas de comunicação devido a fatores de diversas naturezas como, por exemplo, a falta de acesso ou de estímulo dessas pessoas ou até mesmo, cabe-nos fazer uma hipótese, de entendimento dos recursos que estão à sua volta.

Dentro dessas limitações, propomo-nos a estudar como se dá essa elaboração de textos escritos, com foco especial e total nos de divulgação científica, para entender como o processo de domínio e de apropriação das ferramentas necessárias a essa tarefa ocorre dentro desse desenvolvimento evolutivo dos seres humanos (no caso, em relação à comunicação científica escrita) e quais suas implicações na aprendizagem.

Em resumo, o presente estudo pretende investigar o uso que faz o sujeito, quando de domínio ou de apropriação do instrumental da escrita, para se expressar, se 
comunicar, empregando esse sistema de simbolização e de que forma esse processo de domínio e de apropriação ocorre, e se ocorre, nesses indivíduos.

\subsection{O papel da ciência na escola}

A ciência é movida por dois mecanismos básicos: a explicação e a justificação. A capacidade da ciência de explicar os fenômenos naturais, bem como os criados pelo homem, é extremamente produtiva, pois gera informações relevantes que melhoram as condições gerais de vida em sociedade. Uma estratégia para tentar cumprir o papel explicativo da ciência é o incentivo à divulgação científica nos diversos meios de comunicação para ter um povo crítico e com opiniões próprias (CABELLO; MORAES, 2005).

A ciência não deve ser feita somente de teoria. Praticá-la e visualizá-la são formas interessantes de divulgar o conhecimento sem fazer com que o aluno sinta-se entediado. Embora nem todos os conceitos se estabeleçam a partir de sua própria representação teórica, a compreensão de conceitos e fenômenos pode ser, em muitos casos, potencializada pelos aspectos atribuídos às imagens e às idéias que estas podem comunicar (SILVA et al., 2006). De acordo com LEMKE (2005), “os objetivos da ciência não podem ser meramente técnicos (...). A educação deve contribuir para a melhora da vida social, ou seja, dar às pessoas uma melhor oportunidade para que tenham uma vida melhor".

Para as crianças, cuja característica peculiar é gostar de colocar "as mãos na massa", uma aprendizagem feita de forma memorística, repetindo o conteúdo do livro didático, sem poder analisar nem questionar e automatizando respostas, torna o processo de aprendizado maçante e tedioso (CABELLO; MORAES, 2005).

A inserção dos alunos em um ambiente em que os meios de comunicação imperam faz com que eles desejem mais de suas aulas, principalmente as de Ciências. Fontes externas são uma forma de fazê-lo entender aquilo que, para ele, pode estar muito além de seu alcance. Porém, não basta somente aplicá-las como ilustração sem um direcionamento do professor; elas devem ser utilizadas com cautela e previamente analisadas pelo educador de modo que o aluno entenda a associação da imagem à teoria e o porquê daquele recurso estar sendo aplicado em determinado conteúdo.

O uso de meios de comunicação faz com que desenvolvam seu espírito crítico e o interesse por disciplinas muitas vezes consideradas maçantes. Filmes, histórias em 
quadrinhos, documentários e até mesmo jornais e revistas são alguns exemplos de materiais que podem ser aplicados em sala de aula para complementar um dado conceito.

O fato é que a educação não mais se restringe à família e à escola - apesar de também ocorrer no interior dessas -, mas se expande a todas as esferas da vida cotidiana, desde os discursos interpessoais até as formas tecnológicas mais complexas da comunicação humana, entre as quais, especificamente, há as imagens técnicas e os audiovisuais em geral. A linguagem escrita é pautada numa lógica linear e num modelo de abstração conceitual, cuja aprendizagem situa a criança como dependente do ensinamento do adulto (PEREIRA, 2002).

A educação de ciências não é apenas trabalhar sob uma base cultural e sim guiar pelos princípios racionais e evidências empíricas e sistemáticas que desafiam o convencional e buscam formas de encontrar alternativas (LEMKE, 2005).

Porém, um dos problemas de uma visualidade calcada na reprodução midiática é que a escola não está preparando os alunos para um mundo repleto de informações externas, já que a própria formação dos professores é deficitária no que se refere a esse conhecimento. Meios de comunicação estão sendo usados dentro da escola, mas nem os professores, tampouco os alunos, possuem oportunidades para trabalharem com o conhecimento que é inerente a este campo (GOMES, 2001).

Mesmo assim, acredita-se que o aproveitamento didático das expressões midiáticas voltadas para o ensino de Ciências possa se dar em três dimensões complementares. A primeira delas refere-se ao trabalho de levar os educandos a reconhecerem as estratégias implementadas na produção textual direcionada para o "grande público", as quais acabam formatando versões peculiares da ciência e dos pesquisadores científicos. Em seguida, é possível favorecer a comparação entre as mensagens de divulgação científica e o teor típico dos livros escolares de Ciências, atividade que permite a constatação de duas formas diferenciadas de se entender a realidade científica e suas implicações no mundo contemporâneo. Finalmente, por meio do uso de ferramentas audiovisuais que possam ser aplicadas nas aulas de Ciências, é possível fomentar a discussão sobre as condicionantes políticas, econômicas e sociais das ciências, prismas que, infelizmente, ainda se apresentam praticamente ausentes na maior parte dos textos escolares que, ao enfatizarem as condições técnicas da ciência, dedicam espaços anêmicos para o questionamento do saber e da prática social deste mesmo saber (FILHO, 2007). 


\subsection{O uso de textos de divulgação científica no ensino de ciências}

Para o estudante, a ciência é muitas vezes interpretada como uma sucessão de equações ou de informações que nada têm em comum com sua vida cotidiana, tornandoa um conhecimento com fim em si próprio. Paralelamente, podemos encontramos pesquisas que apontam para a contribuição prática, principalmente em relação à produção escrita de argumentos. (SOUZA, 2010)

No entanto, podemos apontar um obstáculo nesse entendimento por parte dos alunos como sendo o fato de que a escola pode não garantir o uso eficaz da linguagem, condição para que os alunos possam dar continuidade e progredir nos estudos, o que leva à indagação sobre a qualidade do leitor e do escritor que a escola pretende formar, já que é, entre outras coisas, o uso que ele faz da escrita que o constitui cidadão do mundo (COELHO, 2002)

Essa afirmação encontra apoio nos Parâmetros Curriculares Nacionais (p. 22, 1997), que coloca que "os objetivos de Língua Portuguesa salientam a necessidade dos cidadãos desenvolverem sua capacidade de compreender textos orais e escritos, de assumir a palavra e produzir textos, em situações de participação social”. Dessa forma, podemos entender que a unidade básica de ensino da língua escrita só pode ser o texto (COELHO, 2002).

Almeida (1998) e Silva e Almeida (1998) propõem a utilização de textos diversificados no ensino de ciências, com ênfase em textos de divulgação científica. Dentre as vantagens resultantes da utilização de tais textos está a possibilidade mais efetiva de constituição de um vínculo entre os estudantes e o conhecimento científico trabalhado nestes textos. Também, a divulgação científica aparece como atividade de caráter informativo e formativo, como instância importante de educação científica informal, com o intuito de diminuir o abismo entre os dois mundos (ADINOLFI, 2005).

De acordo com Orlandi (2001, p. 151), “o discurso da divulgação científica parte de um texto que é da ordem do discurso científico e, pela textualização jornalística organiza os sentidos de modo a manter um efeito-ciência, ou seja, encena na ordem do discurso jornalístico, através de uma organização textual, a ordem do discurso científico. Além disso, o discurso da divulgação científica é uma articulação específica com efeitos particulares, que se produzem pelo seu modo de injunção a seu modo de circulação, estipulando trajetos para a convivência social com a ciência”. 
Assim, elaboramos uma proposta para os alunos de Pré-Iniciação Científica (PIC) que pudesse utilizar textos alternativos, como o artigo científico, além do livro didático, para a elaboração de artigos de divulgação científica.

Nossos objetivos englobam, principalmente, o aperfeiçoamento da habilidade de comunicação escrita dos alunos em linguagem científica e a familiarização desses alunos com as atividades de pesquisa científica.

De acordo com Geraldi (1999, p. 36), “a contextualização da escrita não se aprende por exercícios, mas por práticas significativas, pois o domínio de uma língua é o resultado de práticas efetivas, significativas, contextualizadas”. Patterson (2001) corrobora ao dizer que o processo de escrita e reescrita, mediante intervenções do professor e dos colegas, proporciona avanços não só de linguagem como também de conhecimentos específicos de ciências, proporcionando explicações mais completas e mais aprofundadas

O desenvolvimento de habilidades de comunicação oral e escrita em linguagem científica é freqüentemente mencionado na literatura como importante para a formação de estudantes (QUEIROZ, 2001). A recomendação de que haja exposição dos alunos a determinadas situações como, por exemplo, àquelas vivenciadas por cientistas no que tange à escrita ou à apresentação de trabalhos, pode ser encontrada em vários trabalhos (KNABB, 1999; TILSTRA, 2001; HENDERSON; BUISING, 2001).

É amplamente reconhecida a necessidade do oferecimento, durante a vida escolar, de condições que façam com que os alunos se desloquem de uma posição de completa dependência com relação ao livro didático para outra posição que os capacite a procurar informações nas fontes primárias da área e criticá-las (EPLING; FRANCK, 1979). Além disso, é importante não só a diversidade e a seleção adequada dos (diferentes) textos, mas principalmente o uso, pois se pode pensar em usá-los de acordo com os diferentes propósitos para os quais foram elaborados, mas também para enriquecer e acrescentar a leitura da pluralidade (KAUFMAN; RODRÍGUEZ, 1995, p. 49). Esta preocupação é relevante, já que muitas informações contidas nessas fontes são de inestimável valor para a resolução de muitos problemas que terão que enfrentar na carreira profissional a ser escolhida em um futuro próximo.

Sanmartí (1997) salienta ainda que ensinar a ler, falar e escrever textos científicos são uma necessidade das aulas de ciências e não apenas pelas características textuais específicas, mas porque um texto científico somente é válido se aquilo que diz faz sentido a partir da própria ciência. $\mathrm{O}$ ensino das formas de um determinado texto 
não deve ser separado da de seus conteúdos, pois isso poderia impedir a aprendizagem de um ou de outro.

Considerando esses argumentos, Abreu (2009) salienta que as diferentes disciplinas escolares podem e devem contribuir para o desenvolvimento de atividades que lhes possibilite aumento gradativo na capacidade de compreensão dos materiais lidos, também, no gosto pela leitura. Logo, o estabelecimento nos alunos do hábito da leitura - fundamental para que possam participar plenamente do desenvolvimento de qualquer disciplina escolar - não é tarefa exclusiva dos professores da área de linguagem.

No entanto, é relevante que os educadores entendam o potencial didático desses outros textos e os apliquem em atividades que possam estimular a discussão e a participação dos alunos em suas aulas.

De acordo com Terrazan e Gabana (2003), os textos de divulgação científica têm, nas aulas de ciências, um lugar privilegiado em comparação a outros textos possíveis para uso didático, pois o "consumo" de revistas de divulgação científica é relativamente alto entre jovens e adolescentes, sobretudo das classes com maior poder aquisitivo. Abreu (2009, p. 28) concorda que os textos de divulgação científica podem contribuir para a construção de um conhecimento abrangente e contextualizado em sala de aula, porém, salienta que usar esses textos não se limita à sua inserção em situações usuais ou tradicionais de ensino, uma vez que requerem planejamento e reestruturação dessas práticas.

Considerando esses pontos, e mesmo com seus pormenores, Almeida e Ricon (1993) têm uma visão otimista sobre o uso de textos de divulgação científica no contexto escolar. Seu otimismo está associado aos seus efeitos motivacionais, apontando tais textos como possibilitadores de maior envolvimento, interesse e gosto, pois os textos de divulgação científica podem aproximar os alunos da ciência dentro e fora da escola.

Ademais, "o uso de textos de divulgação científica em sala de aula possibilita e auxilia a discussão de fatos/acontecimentos que estão vinculados com o cotidiano dos alunos. E isto contribui principalmente no sentido de apontar a viabilidade de se atingir possíveis mudanças curriculares que levem em conta a presença forte e permanente da Ciência e Tecnologia no mundo contemporâneo" (TERRAZZAN; GABANA, 2003, p. $8)$. 
Em seus estudos, Abreu (2009) verificou que, de modo geral, o uso de textos de divulgação científica no ensino de ciências apresenta como principais objetivos o auxílio ao processo de ensino e aprendizagem de conteúdos específicos das disciplinas, o aperfeiçoamento das habilidades de comunicação oral e/ou escrita dos estudantes e o favorecimento de seu entendimento sobre o processo de construção do conhecimento científico.

Já Nascimento (2005) reconheceu duas origens para os possíveis problemas decorrentes da utilização de textos de divulgação científica, os quais se encontram relacionados às mediações que ocorrem: o processo de produção do texto de divulgação científica e a sua inserção na sala de aula. A primeira mediação é caracterizada pela remodelização do conhecimento científico, que é fundamental, pois, nesse processo, a linguagem utilizada nos textos de divulgação científica pode confundir, complicar e até mesmo veicular de forma errada os conceitos científicos neles apresentados. A segunda mediação, ocorrida já no âmbito do ensino formal, acontece no ato da leitura. Durante a interação entre leitor e texto, estabelecem-se diferentes sentidos, de modo que a compreensão dos conceitos e fenômenos científicos pode estar mais próxima ou mais distante do significado aceito e compartilhado por aqueles que o produziram. É nesse momento que a simplificação da linguagem científica poderá produzir diferentes sentidos e consolidar-se ou não como um obstáculo à aprendizagem do conceito cientificamente correto.

Sem dúvida alguma, a capacidade de escrever bem é extremamente importante para uma carreira de sucesso em ciências e em outras profissões. Assim, essa dificuldade que alguns alunos podem apresentar pode ser limitante para seu futuro (QUEIROZ, 2001). Dessa forma, o uso da linguagem escrita como ferramenta para melhorar a compreensão dos conceitos pelos estudantes e facilitar a comunicação entre alunos e professor, é constante em salas de aulas numerosas, onde se verifica com freqüência o pouco envolvimento dos alunos com a disciplina e, por conseguinte, um desenvolvimento crítico mais lento (QUEIROZ, 2001).

\subsection{Textos científicos e formação crítica}

Em relação à formação crítica do leitor, podemos citar a formação do leitor de ciência. Segundo Silva (2002), a leitura surge como um conceito fundamental na análise das interações entre textos e sujeitos; ela é vista não somente como um meio de 
organizar os conceitos científicos, mas, também, as interações sociais entre professores, seus alunos e a comunidade escolar. Desse modo, atividades de leitura poderiam contribuir para diminuir o distanciamento entre o aluno e o conhecimento científico, o qual, muitas vezes, reflete e reforça uma falta de motivação para seu aprendizado. Já Gama (2005) salienta que ao nos preocuparmos com a formação de leitores de ciência demonstramos interesse em contribuir para a formação de cidadãos que tenham conhecimento suficiente para compreender e questionar a ciência de seu tempo, conscientes da necessidade de relacionar os avanços tecnológicos ao contexto históricosocial em que vivem, entender notícias de teor científico e saber lidar com informações do campo científico.

Martins, Cassab e Rocha (2001) sugerem que estratégias didáticas - que valorizam o contato dos alunos com diferentes tipos de textos científicos e expressam uma variedade de formas de argumentação e pontos de vista - podem trazer certos benefícios. Entre as contribuições geradas por este contato ressaltam-se: acesso a uma maior diversidade, e até divergência, de informações; desenvolvimento de habilidade de leitura e domínio de conceitos, de formas de argumentação e de elementos de terminologia científica. Assim, passar a conhecer uma variedade de tipos de textos científicos, desde reportagens de mídia até originais de cientistas, é condição para tornar-se um participante da cultura científica (ABREU, 2009).

Almeida e Ricon (1993) vêem os textos de divulgação científica e também os literários como uma possibilidade de acesso a ocorrências e controvérsias da ciência e da tecnologia; um meio para obter informações sobre inovações científico-tecnológicas, de desenvolver no estudante o gosto e o interesse pela leitura e pela ciência e, conseqüentemente, sua compreensão, contribuindo para a formação de hábitos e atitudes que permanecerão após o término das atividades estudantis.

Considerando esses argumentos, percebemos o quanto é importante desenvolver o interesse dos alunos por atividades que contribuam para sua formação crítica. Gama (2005) afirma que, além de considerar o contato dos estudantes com a ciência como algo não restrito ao espaço escolar, a escola e a universidade necessitam aceitar a premissa que os estudantes são produtores de sentidos, dentro e fora das salas de aula, e que a circulação desses sentidos é simultânea.

Ademais, alguns estudos apontam o interesse da comunidade de pesquisadores em educação em ciências no funcionamento de textos de divulgação científica no 
ambiente escolar a partir de uma variedade de perspectivas e pontos de vista (ABREU, 2009).

Essa afirmação tem respaldo nas atuais recomendações curriculares que procuram estimular o uso de diferentes textos nas aulas de ciências e salientam as vantagens provenientes dessa leitura em relação a vocabulário e entendimento conceitual:

Além do livro didático, outras fontes oferecem textos informativos: enciclopédias, livros paradidáticos, artigos de jornais e revistas, folhetos de campanhas de saúde, de museus, textos da mídia informatizada etc. É importante que o aluno possa ter acesso a uma diversidade de textos informativos, pois cada um deles tem estrutura e finalidade próprias. Trazem informações diferentes, e muitas vezes divergentes, sobre um mesmo assunto, além de requererem domínio de diferentes habilidades e conceitos para sua leitura (BRASIL, 1997, p. 124).

Martins, Cassab e Rocha (2001) explicitam que "o discurso científico engloba uma série de formações discursivas (o ensino de ciências na escola, a divulgação nos meios de comunicação, a disseminação de resultados de pesquisa na comunidade de pares), cada uma delas relacionadas a um conjunto particular de textos com estruturas genéricas distintas (livros didáticos, reportagens, artigos científicos)”. Assim, podemos entender que a aplicação didática de outros tipos de textos pode fornecer experiências variadas de aprendizagem para os alunos. Contudo, esses autores não acham que a apropriação didática seja de forma automática: "um entendimento do seu funcionamento em cada contexto, das suas condições de produção e de seus efeitos sobre suas audiências, da natureza das reelaborações discursivas envolvidas nas recontextualizações dos mesmos, em particular da natureza das adaptações de textos científicos para sua utilização em contextos educacionais" (MARTINS; CASSAB; ROCHA, 2001). Por esse motivo, entende-se que seja necessária a ajuda do professor para ler esses textos de forma crítica, uma vez que não tenham sido elaborados para fins didáticos.

Também, a familiarização dos estudantes com as atividades de pesquisa científica é apontada por vários pesquisadores como de primordial importância para a formação de alunos (QUEIROZ; ALMEIDA, 2004; BALL et al., 2004; HUTCHINSON; ATWOOD, 2002). Essa familiarização, que pode acontecer com a leitura de artigos de divulgação científica, também pode ocorrer com a participação dos alunos em atividades como as de pré-iniciação científica. Contudo, considerado que 
essa não seja uma prática adotada em muitas universidades e acessível a todos os estudantes, a utilização do artigo científico é sugerida por alguns autores como uma alternativa para o estabelecimento de uma ponte entre as atividades realizadas em sala de aula e as atividades de pesquisa científica (SANTOS, 2006).

\subsection{Pré-iniciação científica}

Um aspecto que vem sendo discutido e colocado em prática no Brasil é a realização da Iniciação Científica (IC) não somente na graduação, mas também no nível médio (MASSI, 2008). Alguns autores (WITTER, 2000; CHICARELLE, 2001; BARIANI, 1998) defendem que a IC deveria ter início juntamente com a escolarização. Segundo Bariani (1998), a pesquisa antes do ingresso na universidade colabora positivamente para o desempenho dos estudantes, oferecendo formas de aprofundamento do conhecimento de diferentes áreas, integrando-os. Chicarelle (2001) chama a atenção para o fato da preocupação com a formação científica parecer ser quase inexistente em graus anteriores à graduação, fazendo com que o aluno chegue à graduação sem 'atitudes científicas' diante do conhecimento.

O Programa de Vocação Científica (Provoc), da Fundação Oswaldo Cruz (Fiocruz), criado em 1986, foi o primeiro programa brasileiro a se preocupar com a implementação da IC no Ensino Médio. O Provoc insere o estudante de Ensino Médio no ambiente de pesquisa de forma planejada, sistemática e com acompanhamento permanente (NEVES, 2001; FERREIRA, 2003). Esse programa merece destaque pelos bons resultados alcançados e por ter inspirado o surgimento de outros programas: em 1995 foi criado o Programa de Iniciação Científica Júnior (PIC Jr.), que até hoje é realizado de maneira similar do Provoc/Fiocruz (MARTINS, 2003). Em 1996, o modelo Provoc foi implantado em outras instituições de ciência e tecnologia, tais como o Centro Brasileiro de Pesquisas Físicas (CBPF), o Centro de Pesquisas e Desenvolvimento Leopoldo Miguez de Mello (CENPES), da Petrobrás, e a Pontifícia Universidade Católica (PUC) do Rio de Janeiro. O modelo também foi implantado em unidades da Fiocruz fora do Rio de Janeiro: o Centro de Pesquisas Aggeu Magalhães, em Pernambuco; o Centro de Pesquisas René Rachou, em Minas Gerais; e o Centro de Pesquisas Gonçalo Muniz, na Bahia. O Provoc também serviu de base para a criação, em 1999, do Projeto Jovens Talentos para a Ciência (PJT) (AMÂNCIO, 2004). 
Em 2007, a Universidade de São Paulo (USP), instituiu o Programa PréIniciação Científica, voltado para alunos da rede pública de ensino, cursando o Ensino Médio, que durante o período de um ano desenvolveram projetos de pesquisa supervisionados por docentes da USP e professores supervisores do Ensino Médio. As atividades foram desenvolvidas no interior da universidade e exigiram do estudante uma dedicação mínima de oito horas semanais durante o período letivo e 16 horas semanais durante o recesso escolar.

Em 2003, o Conselho Nacional de Desenvolvimento Científico e Tecnológico (CNPq) criou o programa denominado Bolsa de Iniciação Científica Júnior (BIC Júnior), resultando em significativa proliferação da IC no Ensino Médio. Esse programa funciona por meio de convênios com fundações estaduais de apoio à pesquisa e, recentemente, passou a incluir também estudantes de $6^{\circ}$ a $9^{\circ}$ anos do Ensino Fundamental II (BRASIL, 2006).

\subsection{Linguagem didática $\mathrm{x}$ divulgação científica}

A utilização do artigo científico também é proposta quando o objetivo é a aproximação dos alunos com a linguagem específica de uma determinada área do conhecimento (SANTOS, 2006). Além disso, o artigo pode mostrar o processo através do qual os cientistas conseguiram produzir seus conhecimentos. Isso é importante no ensino de ciências, pois se acredita que o conhecimento sobre a forma como os cientistas trabalham e alcançam as suas descobertas pode tornar os indivíduos mais críticos e engajados na discussão de questões que trazem em seu bojo julgamentos sobre a ciência. Nesse sentido, alguns autores têm visto o artigo científico como um instrumento capaz de fomentar discussões a respeito do processo de construção da ciência (CAMPANARIO, 2004; SANTOS; QUEIROZ, 2005).

Apesar dos avanços tecnológicos e da enorme variedade de materiais curriculares, atualmente disponíveis no mercado, o livro didático continua sendo o recurso mais utilizado no ensino de Ciências. Essa centralidade lhe confere status e funções privilegiadas na medida em que é através dele que o professor organiza, desenvolve e avalia seu trabalho pedagógico de sala de aula. Para o aluno, o livro é um dos elementos determinantes da sua relação com a disciplina. A lembrança que grande parte das pessoas tem de disciplinas cursadas está relacionada a livros didáticos. Essa peculiaridade também condicionará suas avaliações, expectativas e interesses por essas 
áreas do conhecimento. Não é raro encontrar pessoas que, devido a "fracassos" em algumas disciplinas durante o período de escolarização, passem a se considerar incapazes de compreender seus conhecimentos, chegando a mitificar e supervalorizar aqueles que compreendem os conceitos científicos. Portanto, é indubitável a marca que o livro didático deixa na vida dos alunos (CARNEIRO; MÓL, 2005).

SALZANO (2004), tendo como base Piaget, considera que o ser humano tem autonomia para aprender, já que possui estruturas lógicas e cognitivas ligadas às próprias operações de aprendizagem. Sendo assim, é importante que o aluno se torne o sujeito de sua própria aprendizagem, desde que o professor forneça meios para isso, uma vez que a verdadeira aprendizagem deve partir de experiências já vivenciadas pelo educando e levar em conta seus interesses e motivações.

É nesse contexto que a divulgação científica pode ter um papel importante, pois pode acrescentar ao aluno o conhecimento necessário para que a aprendizagem seja intensificada.

Os diversos meios de divulgação científica podem servir como complemento ao livro didático, uma vez que a presença desse recurso em sala de aula é imprescindível. Aliar artigos científicos ao livro seria uma forma de atualização e concretização da Ciência para o aluno, já que teria em mãos não apenas uma teoria, mas sim sua aplicação no dia-a-dia.

Conteúdos como biologia celular, ecologia, genética poderiam ser encarados de forma diferente pelos alunos, pois são assuntos tratados em revistas e jornais quase de modo corriqueiro.

Outro fator que pode favorecer o uso de meios alternativos em sala de aula é a linguagem cotidiana usada, principalmente, em veículos de mídia impressa. De forma direta, a disciplina de Ciências é decifrada pelo uso de termos e palavras usados de forma a atingir o leitor, ou seja, são usados vocábulos mais simples e de fácil entendimento, o que nem sempre acontece nos livros didáticos.

Segundo Jorge e Puig (2000), para aprender ciência é necessário aprender a falar, escrever e ler ciência de maneira significativa. Isso implica também em aprender a reconhecer as diversas maneiras de expressar um mesmo significado, as diferenças entre a linguagem cotidiana e a linguagem científica e as principais características de cada tipo de discurso (SÁ; QUEIROZ, 2007) 
Assim, temos duas ferramentas importantes na construção do saber científico de um estudante: o livro didático, que nos enriquece com toda sua teoria, e a divulgação científica, que pode complementar a teoria com aplicações práticas no cotidiano.

\subsection{Linguagem científica}

É fato que vivenciar um determinado ambiente faz com que incorporemos novos vocábulos, tornando-nos aptos a compreender textos que até então considerávamos difíceis de entender. O desenvolvimento dessa habilidade pode vir tanto da leitura quanto da escrita.

O conhecimento científico é, de fato, o resultado de um complexo processo de transposição do conhecimento científico, incorporado em manuais universitários, para o contexto do ensino médio e fundamental de Ciências. Neste sentido, não há uma exata correspondência entre o conhecimento produzido pelos cientistas e o conhecimento científico que é ensinado em nossas escolas (VILLANI; NASCIMENTO, 2003).

Alguns autores se referem ao processo de ensino e aprendizagem de ciências como "enculturação", ou seja, a educação é vista como um processo de apropriação da cultura científica. Para outros, como LEMKE (1990), aprender ciências significa se apropriar do discurso científico, isto é, aprender como determinados termos se relacionam entre eles e com o contexto em que são utilizados para produzir significados específicos. Essas duas novas perspectivas convergem quanto à necessidade de ampliar o conceito de educação em ciências e estendem esse conceito à necessidade de considerar o papel da linguagem na ciência para o processo de ensino e aprendizagem de Ciências (VILLANI; NASCIMENTO, 2003).

O conhecimento científico é composto por elementos, tais como leis, teorias, conceitos e princípios científicos, na forma de uma grande estrutura. Assim, a ciência não requer apenas palavras com significados específicos, mas sim uma linguagem própria capaz de tornar possível o seu aprendizado e principalmente seu desenvolvimento. A linguagem científica é, portanto, mais que o registro do pensamento científico. Ela possui uma estrutura particular e características específicas, indissociáveis do próprio conhecimento científico, estruturando e dando mobilidade ao próprio pensamento científico. O domínio da linguagem científica é uma competência essencial tanto para a prática da ciência quanto para seu aprendizado (VILLANI; NASCIMENTO, 2003). 
Dessa forma, cabe à escola priorizar gêneros que caracterizem usos públicos da linguagem, como por exemplo, dentre os escritos, a notícia, o editorial, o artigo de divulgação científica, o literário e, dentre os orais, o debate, a entrevista, o seminário. Simulando situações em que esses textos são realizados na esfera social, criam-se condições para que o aluno reflita criticamente, exercite formas de pensamento mais elaboradas e abstratas e, também, contemple a estética dos usos artísticos da linguagem (GRILLO; OLÍMPIO, 2006).

A discussão de idéias é importante para gerar, clarificar, compartilhar e distribuir idéias entre o grupo, enquanto o uso da escrita como instrumento de aprendizagem realça a construção pessoal do conhecimento. Uma estratégia instrucional cercada de discussão de idéias e escrita devia aumentar a aprendizagem mais do que usando qualquer uma destas duas modalidades sozinha. O emprego dessas duas atividades de linguagem na construção do conhecimento científico é fundamental para a solidarização e consolidação do conhecimento (RIVARD; STRAW, 2000).

A escrita, como instrumento cognitivo, tende a ser uma ferramenta discursiva importante por organizar e consolidar idéias rudimentares em conhecimento mais coerente e bem estruturado. Essas capacidades dizem respeito àqueles conhecimentos necessários que o aluno lança mão no momento da produção de um texto: a sua adaptação às características do contexto e do referente, o uso de modelos discursivos e a dominação das unidades lingüísticas e operações psicolingüísticas. Estas capacidades de linguagem são necessárias ao aprendiz em uma produção de um gênero numa situação de interação determinada. Os aspectos tipológicos dos textos estão relacionados com as capacidades de linguagem dominantes apresentadas pelo autor/locutor ao construir o texto. Cada uma dessas capacidades está diretamente ligada a um gênero discursivo e neste as capacidades de linguagem não aparecem de forma estanque e única - pode haver dentro de um mesmo texto várias capacidades de linguagem interagindo, pois o que determina sua categorização dentro de um gênero é a capacidade de linguagem que prevalece e a sua intenção comunicativa (OLIVEIRA; CARVALHO, 2005). 


\section{OBJETIVOS}

As habilidades de escrita e leitura em linguagem científica são extremamente importantes, embora seja pequena a atenção dispensada ao desenvolvimento de tais habilidades (WHELAN; ZARE, 2003). Sendo assim, pode ser notável a dificuldade apresentada pela maioria dos estudantes quando se depara com textos (ou até mesmo situações) que contêm uma linguagem relacionada à comunicação científica, pois eles, muitas vezes, não podem identificar conceitos aprendidos em sala de aula. Com base nesses fatos, é possível encontrar na literatura alguns pesquisadores que usam textos de divulgação científica para ajudar os estudantes tanto na leitura quanto na escrita de textos que possuam uma linha científica, porém compreensível para os indivíduos.

Este estudo parte do pressuposto que o desenvolvimento de habilidades relacionadas à elaboração de artigos de divulgação científica pode ajudar os estudantes a adquirir uma linguagem mais apurada em relação à ciência, auxiliá-los quanto à escrita, seja ela no âmbito científico (que é nosso propósito) ou não e possibilitar a manifestação de opiniões e interesses dos alunos pela ciência, favorecendo-lhes, também, uma formação mais crítica.

Neste estudo objetivamos descrever uma proposta de ensino baseada na apropriação e no domínio de ferramentas necessárias para a elaboração de textos de divulgação científica e discutir o seu potencial no desenvolvimento da habilidade de escrita desse tipo de texto nos estudantes.

A proposta foi aplicada em alunos de Ensino Médio que participaram de um projeto de pré-iniciação científica na Universidade de São Paulo durante o período de um ano.

Os dados coletados durante a aplicação da proposta foram analisados tendo como referencial a Teoria da Ação Mediada de Wertsch, o processo de internalização de Vygotsky e a absorção da linguagem científica abordada por Lemke.

As análises feitas foram de extrema importância para a compreensão de nosso problema de pesquisa - de que forma a comunicação científica escrita pode ajudá-los no ambiente escolar e como se dá o desenvolvimento da escrita desses textos a partir de atividades que possam propiciar a apropriação e o domínio de ferramentas e a aquisição de uma linguagem necessária para isso? - e, acreditamos, poderão ser extremamente úteis para outros estudos relacionados ao assunto na área de educação em ciências. 


\section{REFERENCIAL TEÓRICO}

Para realizar o estudo, apoiamo-nos em quatro pontos:

- os estudantes precisaram de alguém e/ou algo para que o estímulo acontecesse. Se não houvesse um mediador, não haveria a apropriação das ferramentas e dos conceitos, tampouco o interesse por aprender algo novo e diferente daquilo ao qual estavam acostumados;

- com a superação desse primeiro obstáculo, há o processo de internalização de conceitos, fazendo com que o estudo evolua;

- a linguagem construída durante todo o processo; e, por fim,

- o discurso obtido ao final do estudo.

O modelo de aprendizagem nesse estudo tem como base a Teoria da Ação Mediada de Wertsch. Em seu livro, Mind as action, Wertsch foca a ação humana ao reconhecer a importância e o papel dos meios de mediação em determinadas ações. Em relação à Teoria da Ação Mediada (TAM), tratou da ação como podendo ser tanto externa quanto interna e realizada por grupos ou indivíduos. Também propõe que sejam considerados conceitos de domínio e apropriação das ferramentas que vão mediar a ação envolvendo o sujeito e o objeto de conhecimento.

Buscando integrar aspectos diversos da ação humana, a ação mediada articula cultura e ação (do sujeito) por meio da categoria de "ferramentas culturais". Ação mediada, portanto, é uma ação que faz uso das ferramentas culturais presentes nas diversas esferas e contextos da vida humana (COLINVAUX, 2003). Também, Wertsch define que a ação mediada envolve uma dialética entre o agente (quem) e a agência (meios ou instrumentos). Sob essa perspectiva, para saber quem executa a ação ou quem fala em um diálogo, por exemplo, é preciso considerar não apenas o sujeito isolado, mas também a ferramenta cultural que ele emprega para agir ou falar (MOREIRA; PINHEIRO; FILHO, 2009). Por ferramentas culturais entende-se não apenas a linguagem, escrita e oral, com seus sistemas de significados, como também outros meios simbólicos, tais como a própria ciência que descreve e explica o mundo, e ainda todo tipo de instrumento, como uma máquina de escrever ou um computador (COLINVAUX, 2003).

A investigação da ação mediada, ao analisar os contextos que embasam a ação, estabelece que a unidade de análise é a própria interação entre sujeito e contexto, o que implica considerar simultaneamente tanto as características do indivíduo como 
ferramentas e contextos. A noção de ação mediada indica um "pensar com ferramentas culturais", configurando, assim, sistemas cognitivos distribuídos que integram o sujeito que pensa aos contextos específicos de sua ação. Assim, pensar é saber usar as ferramentas culturais de modo apropriado nos diversos contextos socioculturais da ação humana, isto é, adquirir a capacidade de usar as muitas ferramentas existentes ao nosso redor (WERTSCH, 1999).

$\mathrm{Na}$ visão de Wertsch, toda ação humana geralmente envolve o uso de meios mediacionais para se atingir um determinado fim e são esses que essencialmente dão forma à ação. Como conseqüência, o foco de análise proposto é o "indivíduo-agindocom-os-meios-mediacionais", ao invés de simplesmente o "indivíduo" (WERTSCH, 1997).

Transpondo esses conceitos para nosso estudo, identificamos a divulgação científica, em sua forma escrita, como um instrumento de mediação, uma ferramenta cultural que pode ser apropriada pelos alunos a fim de se atingir um determinado objetivo - no caso, aprender mais sobre certo tipo de conceito (DNA) - a ponto de conseguir transmiti-lo para outros indivíduos. A pergunta que surge dessa afirmação é a seguinte: quais as ferramentas culturais relacionadas à divulgação? Uma das respostas seria a cultura científica, que poderia abranger as dimensões conceituais, o saber-fazer da atividade científica entre outros. A definição segundo a qual a ciência envolve um conjunto pouco articulado de práticas intelectuais e materiais diversos pode constituir um ponto de partida útil para uma análise aberta das ferramentas científicas (JENKINS, 1999). O uso constante de uma ferramenta pode levar o aluno a desenvolver uma habilidade, por exemplo, o ato de escrever artigos de divulgação científica com mais facilidade. No entanto, não podemos ter certeza absoluta de que seja uma apropriação quem sabe um domínio das ações, que ocorre em um plano mais externo (DINIZ, 2005).

Ao atingir determinada meta, no caso o domínio de conceitos e a apropriação das ferramentas, chegamos a um novo ponto na pesquisa: a internalização. Desde o trabalho desenvolvido em Voices of mind, o autor aproxima a teoria de Vygotsky (internalização) da teoria de Bakhtin (dialogismo e gêneros do discurso), estendendo as pesquisas de Vygotsky sobre a mediação humana através de, pelo e com signos. Dessa forma, o processo internalização passa a ser considerado como domínio e apropriação.

Partindo desse pressuposto, se a introdução de ferramentas psicológicas ou meios mediacionais na ação pode alterar ou redefinir essa ação e a estrutura das funções mentais e considerando que a linguagem hipertextual altera a forma de leitura e de 
construção de conhecimento, podemos admitir que os mecanismos psicológicos superiores como percepção, memória, atenção voluntária, podem ser alterados, pois são conformados pela ação interativa com a ferramenta cultural e com outro agente, constituindo o que Vygotsky denominou de processo de internalização. Esse processo de reconstrução interna de fundamental importância para o desenvolvimento das funções psicológicas superiores se caracteriza por duas transformações: a) uma operação inicial representada por uma atividade externa é reconstruída e começa a ocorrer internamente; e b) um processo interpessoal é transformado num processo intrapessoal. O funcionamento interno é resultante de uma apropriação das formas de ação que estão intimamente interligadas a estratégias e conhecimentos dominados pelo sujeito como, também, a ocorrências no contexto interativo (VYGOTSKY, 1998).

Em síntese, internalização é o processo pelo qual certos aspectos da estrutura da atividade, que se realizam num plano externo, passam a fazer parte do plano interno. Desse modo, toda função psicológica superior atravessa uma fase externa em seu desenvolvimento, uma vez que inicialmente foi uma função social. Para Vygotsky (1998), a internalização é um processo implicado na transformação dos fenômenos sociais em fenômenos psicológicos. A internalização transforma o processo em si, mudando sua estrutura e função. Desse modo, a internalização é sempre uma reconstrução. Já para WERTSCH (1999), a internalização é o processo de controle sobre as formas de signos externos. Assim, adquirir controle voluntário sobre um signo no plano intrapsicológico é, portanto, um processo de internalização.

Em nosso estudo, o processo de internalização pode ser avaliado no seu decorrer, onde, por meio da linguagem e discurso, é possível avaliar se o aluno apropriou-se ou não das ferramentas culturais. Dependendo do nível de domínio e apropriação que o aluno desempenha sobre o conceito, este irá exercer uma influência maior ou menor em seu trabalho produzido. Para isso, utilizamos como proposta metodológica a elaboração e escrita de artigos de divulgação científica. Essas atividades foram planejadas com o objetivo de fornecer aos alunos um suporte de conteúdo e informações necessários à escrita desses trabalhos. Assim, eles teriam as ferramentas relevantes ao desenvolvimento desses artigos e estariam, ao mesmo tempo, se apropriando, e até mesmo internalizando, esse determinado conteúdo, uma vez que teriam contato com fontes externas que, provavelmente, seriam uma forma de reconstrução de conhecimentos, considerando que os possuíssem previamente. 
A formação de conceitos, segundo VYGOTSKY (2001), resulta de generalizações em níveis diferentes de conceitos, ou seja, consiste em organizá-los em um sistema, tendo como critério o grau de generalização. Esse entendimento faz com que o ensino de Ciências e as atividades usadas no processo de aprendizagem - a divulgação científica, por exemplo - se voltem para um processo de apropriação cultural específico e de internalização, ajudando na formação de um modo particular de pensar, de ver a realidade e até de escrever, tendo como base o desenvolvimento de conceitos científicos como ferramentas desse pensamento. É preciso salientar que o desenvolvimento de conceitos é, ao mesmo tempo, uma mudança na forma de lidar prática e empiricamente com o objeto e na forma de pensar teoricamente (CAVALCANTI, 2005).

Esse processo de internalização adquirido pela prática da escrita levaria, finalmente, à transposição desse conhecimento por meio da linguagem e do discurso.

$\mathrm{Na}$ internalização, a linguagem desempenha papel decisivo, pois ela é um instrumento regulador da ação e do pensamento. Por meio dela, pode-se influenciar a ação e o pensamento das pessoas, bem como nossos próprios pensamentos e ações (FITTIPALDI, 2006). Vygotsky (1987) atribui importância à linguagem, pois além da função comunicativa, ela é essencial no processo de transição do interpessoal em intramental, na formação do pensamento e da consciência, na organização e planejamento da ação, na regulação do comportamento e em todas as demais funções psíquicas superiores do sujeito, como vontade, memória e atenção. Além disso, a linguagem é entendida como um sistema simbólico (mediador semiótico), que tem como funções o intercâmbio social, ou seja, a comunicação entre os indivíduos, o que permite a transmissão, preservação e assimilação de informações e experiências acumuladas pelo homem (VERGNAUD, 1993).

A importância da linguagem escrita no desenvolvimento do indivíduo parte do entendimento de Vygotsky (1998) de que esta não deve ser entendida como uma habilidade que se executa com as mãos, mas sim como uma forma de linguagem nova e complexa, com o foco voltado à operação do pensamento com signos. Para o autor, a linguagem escrita demandaria, em relação à linguagem oral, um trabalho intelectual mais elaborado, principalmente pela necessidade de uma dupla abstração, evidenciada na falta do elemento sonoro e do interlocutor. $\mathrm{O}$ uso da linguagem escrita exige maior independência, voluntariedade e liberdade por parte do indivíduo; dessa forma, a sua importância na relação indivíduo - conhecimento não pode ser apenas entendida como 
uma possibilidade mecânica de registro de informações para as gerações futuras - a mais antiga e ainda mais utilizada -, mas como um importante trabalho intelectual de operação com signos, símbolos culturais, no qual se insere o respeito à semântica e às regras ortográficas de sua exteriorização. Assim a escrita, além de servir como instrumento de mediação entre os agentes, também aparece como poderosa atividade intelectual para que o indivíduo trabalhe o conhecimento de uma forma mais rigorosa e sistematizada, tanto em nível interpsíquico como intrapsíquico (WELLS, 2001).

De acordo com Lemke (1998a), a linguagem em si é o sistema mais notável dos recursos semióticos. Toda palavra é rica em significados, os quais se acumulam quando encontrados em diferentes contextos. Toda palavra é uma intersecção de muitas declarações e discursos que fazem uso dela. Toda palavra em um contexto é parte de uma possível troca de significados entre diferentes membros de uma comunidade. Em relação às ciências, o objetivo da educação científica deve ser capacitar os estudantes para que utilizem todas essas linguagens de modo significativo e apropriado e, acima de tudo, integrem-nas funcionalmente no desempenho da atividade científica.

As linguagens são abstrações analíticas provenientes de práticas sociais incorporadas. Tanto o discurso quanto a escrita utiliza recursos semióticos, assim como a linguagem, e estão relacionados à construção de significados, seja qual for o recurso semiótico utilizado (LEMKE, 1998b).

Já Bakthin (1928) concebe a linguagem prática e cotidiana como um processo de geração do acontecimento. Quando inserida na divulgação científica, os enunciados da divulgação dialogam com o discurso científico. Portanto, a divulgação científica particulariza-se pela exteriorização da ciência e da tecnologia para outras esferas da atividade humana, nas quais perdem sua finalidade de avanço do estado de conhecimentos de uma área do saber para visar à criação de uma cultura científica no destinatário (GRILLO, 2008).

A escrita de artigos de divulgação científica é uma prática que desenvolve a busca e reconstrução do conhecimento, o espírito crítico do aluno e a linguagem (aquisição de vocabulário, principalmente). Assim, ao elaborarmos este estudo, procuramos salientar a apropriação das ferramentas culturais, a internalização dos conceitos e o desenvolvimento de uma linguagem inerente à cultura científica. 


\section{METODOLOGIA DE ENSINO}

\subsection{O programa de Pré-Iniciação Científica}

O programa de Pré-Iniciação Científica da Universidade de São Paulo foi lançado em setembro de 2008 e é uma iniciativa da Secretaria Estadual de Educação em São Paulo, com o apoio da Pró-Reitoria de Pesquisa da Universidade e o patrocínio do Banco Santander. Sua proposta é oferecer a alunos de escolas da rede estadual do Ensino Médio, com idade entre 15 e 18 anos, a oportunidade de entrar em contato e conviver, nos laboratórios e junto a grupos de pesquisa da USP, com procedimentos e metodologias adotados em estudos científicos de diversas áreas do conhecimento.

Ao todo, 380 alunos de 55 escolas públicas foram selecionados pela Secretaria de Educação, que teve como critério o desempenho escolar de cada inscrito. Esses alunos participaram de 160 projetos de pesquisa de 35 unidades da USP nos municípios de São Paulo, Lorena, Bauru, Piracicaba, Pirassununga, Ribeirão Preto e São Carlos. Os trabalhos foram supervisionados por 266 pesquisadores da Universidade e 63 professores de suas escolas de origem. Os estudantes e educadores receberam uma ajuda de custo (bolsa de estudo destinada às eventuais despesas como transporte) e dedicaram oito horas semanais, durante o ano letivo, para o desenvolvimento de atividades científicas. Durante as férias, essa carga horária subiu para 16 horas semanais. A seleção desses alunos foi realizada pela Secretaria Estadual de Educação e teve como critério o desempenho escolar de cada inscrito.

O primeiro ciclo do programa foi encerrado em 29 de outubro de 2009, em uma cerimônia oficial, e os dois melhores trabalhos foram premiados. Todos os alunos participantes do programa receberam um certificado da Universidade. (REVISTA FAPESP)

\subsection{Sujeitos da pesquisa}

A inserção de estudantes de Ensino Médio em ambientes de pesquisa é uma das formas de operacionalizar os programas de pré-iniciação científica (PIC) que vêm se institucionalizando nos laboratórios das universidades e centros de pesquisa brasileiros. Apesar de sua diversificação no processo de seleção e acompanhamento, esses programas são balizados pela crença de que a relação pesquisador - orientando 
contribui para o desenvolvimento pessoal e profissional do jovem (FILIPECKI; BARROS; ELIA, 2006).

Levando isso em consideração, elaboramos um estudo em que seis alunos, integrantes do programa de pré-iniciação científica na Universidade de São Paulo e estudantes da Escola Estadual Profa. Hadla Feres, região de Carapicuíba, participassem e desenvolvessem suas habilidades em relação à escrita de artigos destinados à divulgação científica.

O trabalho teve duração de um ano, de acordo com o programa de pré-iniciação científica da Universidade.

O grupo foi composto por quatro alunos do $2^{\circ}$ ano e dois do $3^{\circ}$ ano do ensino médio. Os encontros eram quinzenais, geralmente às quintas-feiras (devido à distância entre suas moradias e a universidade) e vespertinos, e ocorreram nas dependências da Faculdade de Educação da USP.

Antes das atividades práticas serem iniciadas, os seis estudantes responderam a um questionário (ANEXO I), no qual constavam questões pessoais e sobre a divulgação científica, para avaliar qual o nível de conhecimento em relação à investigação proposta. Esse questionário foi aplicado pelo orientador do projeto.

Com base em suas respostas, a metodologia de coleta de dados começou a ser organizada e dividida em seis fases.

\subsection{Perfil dos sujeitos da pesquisa}

Nosso grupo de pesquisa foi composto por seis alunos (um menino e cinco meninas) com idades de 16 e 17 anos. Os estudantes moravam na periferia de Carapicuíba, município de São Paulo. Todos eles tinham acesso à Internet, embora alguns a possuíssem na forma discada. De acordo com o questionário, possuíam hábitos de leitura regulares e liam desde gibis até jornais. O rapaz trabalhou durante dois meses no decorrer desse estudo, enquanto o resto do grupo dedicava-se apenas aos estudos. Em relação a seus hábitos de estudo, todos eles mantinham uma disciplina de estudo diária que variava de uma a cinco horas por dia. O grupo foi escolhido pelo seu desempenho curricular de acordo com os critérios de avaliação aplicados no Edital, considerado ótimo na época do estudo. 


\subsection{A proposta}

A organização da proposta foi estruturada para visar ao desenvolvimento desses alunos quanto à escrita de artigos científicos. No entanto, para que isso pudesse ser alcançado, foi necessário delinear um estudo para que esses alunos entendessem o modo como gostaríamos que eles realizassem suas tarefas para que pudéssemos analisá-las da forma mais adequada possível.

Assim, a pesquisa previu uma série de tarefas, que mostrassem seu desenvolvimento ao longo do estudo. No entanto, essas tarefas foram definidas levando em conta a fase anterior pela qual eles passavam, ou seja, se uma das fases não atendesse às nossas necessidades, ela poderia ser repetida com uma nova abordagem; caso contrário, uma nova etapa de "crescimento" era estabelecida e o processo teria continuidade.

Assim, nosso estudo foi dividido em fases que serão descritas a seguir.

\subsubsection{Fase I}

Antes de iniciarmos o estudo propriamente dito, levamos em consideração o fato que não conhecíamos os alunos com quem iríamos trabalhar tampouco como eram seus conhecimentos em relação ao conteúdo curricular e extracurricular.

Com isso em mente, resolvemos que seria necessária uma triagem desses conhecimentos para que pudéssemos colocar nossa proposta em andamento.

A melhor forma encontrada para ter acesso a essas informações foi a aplicação de um questionário - primeiramente, em nossos alunos e, depois, nos alunos da escola em que estudavam. Dessa forma, teríamos uma noção geral de como era o nível de conhecimento deles.

Assim, o primeiro passo foi os seis alunos responderem a um questionário em que constavam perguntas pessoais sobre alguns detalhes de sua vida (ANEXO I).

Em seguida, elaboramos outro questionário em que constavam perguntas como, por exemplo, qual era o conhecimento deles em relação à divulgação científica (ANEXO II). Essa etapa foi importante, pois nos mostrou como deveria ser nossa abordagem quanto à comunicação escrita, que era nosso foco de trabalho. Também nos deu direcionamento para o que fazer no que se referia ao reconhecimento de nosso grupo.

Com os questionários em mãos, foi possível analisar o quanto esses alunos sabiam sobre o que seria a comunicação escrita. Foi, então, que uma nova idéia surgiu: 
se eles pensam assim, como pensariam seus colegas? Qual seria o nível de conhecimento desses estudantes sobre certos assuntos divulgados na mídia?

Levando em conta o momento da pesquisa (final de 2008), resolvemos abordar alguns temas muito questionados e, até mesmo, considerados polêmicos em todos os meios de comunicação. Um deles, e para nós de grande valia, foi o DNA (a escolha desse tópico é explicada mais abaixo).

Os questionários também tiveram a finalidade de nos ajudar na escolha do tema que seria proposto a esses alunos para uso em seus artigos. $\mathrm{O}$ objetivo era escolher algo que fosse de muito interesse do grupo, o que estimularia a pesquisa e o aprofundamento que deveriam ser postos em prática por meio da escrita. Já que a televisão e a Internet são meios de comunicação comuns para a maioria dos jovens, o ideal é que aproveitássemos esses veículos o máximo possível para entender como eles absorviam o que viam ou liam - eis o porquê do teor das perguntas nos questionários.

Com isso esboçado, fizemos uma reunião com o grupo de PIC para, em conjunto, elaboramos um questionário (ANEXO III) que contivesse esses tipos de questionamentos e que pudesse ser aplicado em seus colegas na escola. Esse instrumento foi dividido em três partes principais:

- informações gerais sobre o aluno, em que constariam questões com nome, idade, religião, lazer etc.;

- 16 perguntas gerais sobre ciências;

- 17 perguntas sobre temas específicos como DNA, aquecimento global, transgenia etc.

O questionário foi levado à escola desses alunos e aplicado nas salas de aula, com o consentimento da diretoria e o apoio do professor de língua portuguesa em exercício nessa instituição (que se prontificou a ajudar em todos os âmbitos possíveis da pesquisa). Como as salas de aula continham mais de 30 alunos cada, decidimos na reunião com os alunos de PIC que dois alunos de cada uma das 56 salas deveriam ser aleatoriamente selecionados para respondê-lo. Acreditamos que dois alunos de cada sala seriam suficientes para uma amostra do que precisávamos saber, ou seja, qual era o nível desses alunos em relação a certos assuntos. Ademais, a escolha aleatória deveu-se ao fato de não haver uma influência nas respostas caso fossem escolhidos apenas alunos com um desempenho favorável, aumentando, assim, as chances de se obter respostas e pontos de vista diferentes. Ao final, os resultados foram compilados pelos alunos do PIC, que as tabularam do modo ao qual estavam acostumados, e o tema foi escolhido 
após considerarmos as questões levantadas pelos alunos de PIC (em uma reunião feita para entrega dos resultados obtidos), o nível de curiosidade desses alunos e a falta de informações sobre os temas propostos no questionário (nesse caso, de modo geral).

\subsubsection{A escolha do tema}

O final de 2008, época em que começamos nossa pesquisa, foi marcado por alguns fatos que acabaram nos auxiliando na escolha do tema. Foi nessa época em que casos policiais eram constantemente abordados por ter, como pano de fundo, o uso de técnicas que ajudavam a "desvendar" o DNA do criminoso. Um desses casos foi o dos Nardoni, que assassinaram a filha Isabella em meados de 2008.

A mídia abordou $\mathrm{o}$ assunto de forma incessante, principalmente a sensacionalista. Todos os canais da TV aberta destacaram o caso em seus telejornais durante meses, sempre encontrando formas de "prender" os telespectadores e fazendo com que estes construíssem opiniões sobre o caso.

No decorrer incansável desse fato, algo foi motivo de atenção no que tange à sua investigação: o uso de técnicas modernas para tentar descobrir possíveis manchas de sangue e, nestas, vestígios de DNA. Isso repercutiu de modo intenso, já que muitas pessoas no país assistiam a seriados considerados verdadeiras manias que abordavam esse tipo de tecnologia. Entre esses está o CSI.

O CSI tornou-se uma verdadeira "febre" no Brasil quando passou a ser exibido na TV aberta. Até então, era conhecido apenas por aqueles que assinavam a TV a cabo ou que compravam DVDs de seriados.

A série CSI: Crime Scene Investigation foi lançada em 2000 nos Estados Unidos e passou a ser exibida aqui em 2001 em um canal de TV a cabo. É um dos grandes sucessos da televisão mundial desde então. Ela destacou-se por mostrar como funciona a perícia criminal, até então desconhecida da população.

O programa trata de um grupo de cientistas forenses que, aliando inteligência a recursos de alta tecnologia, resolve os crimes mais assombrosos da cidade de Las Vegas. A competente equipe de perito é comandada por um entomologista, cujas citações enigmáticas e imenso conhecimento sobre os mais diversos assuntos já se tornaram célebres. O drama é inovador na abordagem dos acontecimentos, assim como nos efeitos visuais, o que, aliados à alta qualidade técnica da produção, roteiros e atuações excelentes, atraem e seguram o telespectador em busca da resolução dos casos 
desde o ano de 2000, quando a série estreou. Mesmo depois de tantos anos, permanece com enorme audiência e surpreende o público a cada episódio (CSI BRASIL).

A partir desse seriado, duas produções independentes da original foram geradas, “CSI: Miami” e “CSI: New York”, além de livros, jogos e produtos em geral.

Também, novos seriados começaram a aparecer, sempre tendo como foco a perícia criminal, embora com abordagens diferentes sobre esse mesmo assunto.

O seriado teve grande impacto entre os jovens e até mesmo em suas aulas de Ciências, em que professores citavam os métodos utilizados pelos peritos nas séries para explicar tópicos relacionados à genética. A televisão destacou fortemente o uso da substância "Luminol", que revela traços de sangue com uma reação química geradora de luz entre diversas substâncias químicas e a hemoglobina, e que aparece constantemente nesses tipos de séries. Várias revistas explicaram o que vinha a ser essa substância e outros equipamentos visualizados anteriormente somente em filmes de ficção, sempre fazendo uma relação com o real e a ficção.

Mas, voltando ao nosso estudo, após a compilação de nossos questionários, percebemos que, em uma das reuniões com nossos alunos de PIC, que eles também tinham muita curiosidade sobre o assunto e que eram fãs incondicionais de seriados desse tipo. Uma das meninas, Andressa, dizia assistir a todos eles e mostrou muito entusiasmo em relação ao assunto.

Assim, considerando os pontos levantados, o tópico "DNA" foi escolhido devido à sua aplicação no cotidiano e à freqüente aparição na mídia. No entanto, os alunos de PIC não souberam de nossa escolha final até a fase seguinte.

\subsubsection{Fase II}

Após a escolha do tema, fizemos uma reunião para explicar o que seria feito a partir de então.

Ainda com base nos questionários, decidimos que, para a realização do projeto de pesquisa escolhido, seria necessário que os alunos tivessem contato com o foco do estudo, ou seja, com os meios de divulgação científica. Nosso objetivo nesse momento era tentar fazer com que eles reconhecessem o modo como a divulgação científica poderia aparecer na mídia. A dúvida era: como fazer isso?

Durante as reuniões, percebemos que os alunos gostavam muito de TV e de filmes, entre outras coisas. Achamos que uma forma de abordagem que poderia ser 
direta e que os estimularia quanto ao nosso estudo seria utilizar, a princípio, um meio de comunicação visual que trouxesse consigo uma carga de informações que nos pudesse ser útil na pesquisa.

Então, ao procurar um filme que pudesse ter essas características, chegamos ao filme "Gattaca - Experiência Genética"1, que apresenta o DNA como tema principal. Nosso foco, ao exibir o filme, era tentar entender se eles eram capazes de separar o real da ficção, se absorviam as informações científicas reais apresentadas e se poderiam relacioná-las com a vida real.

O filme "Gattaca" é uma interessante reflexão sobre os caminhos a que a engenharia genética pode levar e os impactos que esta tecnologia - e a ciência de um modo geral - pode ter na sociedade. Passado em um tempo futuro, Gattaca mostra uma sociedade em que as corporações tornaram-se mais poderosas que o Estado e em que a manipulação genética criou uma nova espécie de preconceito e hierarquia racial, legitimada pela ciência (COMCIÊNCIA, 2009).

Essa obra cinematográfica foi selecionada por apresentar questões, verídicas ou não, sobre o código genético e o modo como ele poderia ser usado em um futuro próximo. O vídeo foi utilizado para mostrar de que forma os conceitos científicos podem aparecer na mídia, levantar questões sobre o DNA e fomentar um debate sobre o assunto, tendo-se o cuidado de explicitar que não poderia ser usado como uma ferramenta teórica, mas apenas como forma de ilustração de uma possível aplicação do contexto em pauta.

O filme foi apresentado em um dos encontros quinzenais, no mês de fevereiro, e exibido nas dependências da faculdade (laboratório de química da Faculdade de Educação). Após sua exibição, iniciamos um debate sobre as questões apresentadas na obra e o modo como podem ser entendidas, caso o filme fosse apresentado em uma sala de aula para exemplificar uma aula com esse conteúdo.

As questões que mais incomodaram os alunos foram "Como é possível saber a seqüência genética?", "É possível que isso possa acontecer em um futuro próximo”?, "O DNA pode ser copiado?", "Seria bom selecionarmos os seres humanos por suas características?". Tentando fazer com que instigassem a curiosidade, conduzíamos a

\footnotetext{
${ }^{1}$ Gattaca é um filme de ficção científica nos EUA em 1997. O filme baseia-se em preocupações sobre as tecnologias reprodutivas que facilitam a eugenia e as possíveis consequências de tais desenvolvimentos tecnológicos para a sociedade. Elenco: Ethan Hawke, Judy Law, Uma Thurman, Xander Berkeley, Gore Vidal, entre outros. Direção de Andrew Niccol. Columbia Pictures.
} 
reunião de modo que não perdessem o foco, fazendo questionamentos que os levassem a pensar sobre o assunto como, por exemplo, "Como vocês acham que o DNA funciona em nosso corpo?", "Ele pode influenciar nossas ações ou é apenas um artifício usando no cinema?", "Em que lugar vocês acham que essas informações foram obtidas"? "Tudo é verdade mesmo ou existe um pouco de imaginação?" etc.

Após a exibição do filme, um questionário breve sobre o entendimento do filme e sua relação com a divulgação científica foi aplicado a esses alunos para que pudéssemos avaliar o quanto eles se apropriaram ou dominaram esse conhecimento nesse espaço de tempo (ANEXO IV).

\subsubsection{Fase III}

A partir desta fase, os encontros foram estruturados para abordar os seguintes aspectos:

- debater e entender as ferramentas usadas para elaborar um artigo de divulgação científica;

- planejar os artigos a serem escritos;

- selecionar o material de apoio a ser utilizado na escrita desses artigos.

Nessa reunião, os alunos foram informados que as atividades a serem executadas daquele momento em diante envolveriam a leitura, a pesquisa, a discussão do tema escolhido e, principalmente, a elaboração de artigos de divulgação científica. Esclarecemos o que era a divulgação científica e qual sua relevância para a aprendizagem, principalmente em sala de aula. Além disso, um pouco sobre a história da divulgação foi passado (o texto foi tirado do site do Núcleo José Reis) para que pudessem ter noção do que estavam aprendendo. Assim, foram instruídos que deveriam dedicar algumas horas semanais para pesquisar mais sobre o tema para entender sua real importância. Orientamos-lhes de forma que fizessem todo o processo de pesquisa, porém sem revelar o objetivo do estudo.

A partir de então, em todas as reuniões quinzenais, e também por correio eletrônico, os alunos receberam as diretrizes relevantes para a elaboração de seus artigos. Foram mostradas as diferenças entre artigo científico e artigo de divulgação científica (em que usamos como exemplo artigos científicos tirados de importantes 
revistas científicas como, por exemplo, a Nature ${ }^{2}$ e textos de divulgação científica como os apresentados na revista Super Interessante) e as ferramentas que poderiam ser utilizadas para se obter um artigo de divulgação científica com conteúdo idôneo como, por exemplo, sites que contivessem artigos científicos provenientes de fontes confiáveis (universidades, centros de pesquisa etc.). A bibliografia foi uma parte muito ressaltada por nós, pois queríamos que pesquisassem artigos com bases confiáveis para que obtivessem o máximo possível de conhecimento científico aplicado no dia-a-dia.

Sempre tendo o tema DNA como base para suas redações, os estudantes foram instruídos a escrever, de forma individual, um artigo de divulgação para que pudéssemos avaliar o quanto dominaram ou se apropriaram das ferramentas e das instruções fornecidas. Também tínhamos como objetivo entender o modo de seleção daquilo que encontrariam pela frente e observar as fontes selecionadas para o desempenho da tarefa, e, principalmente, como se apropriariam dos termos científicos de modo que os usassem em seus escritos. O processo demorou em torno de dois meses (quatro reuniões), pois os alunos se encontravam em avaliações mensais e bimestrais escolares no período tendo pouco tempo dedicado à tarefa. Durante a fase de elaboração, também trocamos mensagens por e-mail com o intuito de sanar as dúvidas que apareciam conforme executavam o trabalho. Questões como "Ele deve ser fictício ou concreto com base em pesquisas?" (Pedro), "Não existe um modelo a ser seguido?" (Mônica) apareceram nesse contexto. Tentamos guiá-los, sem fazer muitos esclarecimentos, pois o objetivo era saber como desempenhariam a tarefa tendo o mínimo de orientação necessária, de modo que fizessem o trabalho com algum êxito, fazendo com que trilhassem nossos interesses. Ao final dessa fase, seis artigos foram entregues dentro do prazo estipulado (ANEXO V).

\subsubsection{Fase IV}

O objetivo dessa nova fase foi avaliar o quanto eles se apropriaram das ferramentas para elaboração de artigos de divulgação científica e como as transporiam para o papel usando os conhecimentos já obtidos anteriormente mais um novo tipo de fonte externa e sem base escrita. Essa foi a forma encontrada para investigar como

Nature é uma das mais antigas revistas científicas mais antigas do mundo: sua primeira edição é de 4 de novembro de 1869. Entre as inúmeras descobertas científicas publicadas na Nature estão a dos raios X, da estrutura em dupla hélice do DNA e o buraco na camada de ozônio (NATURE). 
ordenariam suas idéias sobre um determinado assunto e descrevê-las-iam, da melhor maneira possível, no formato de um artigo.

Assim, foram por nós instruídos a escrever um novo artigo de divulgação científica sobre o tema DNA, porém tendo como base uma entrevista feita com um pesquisador da área.

Antes do início do processo prático, uma nova reunião foi feita para que recebessem todas as orientações possíveis - desde dicas básicas como ferramentas de busca na Internet até possíveis locais e profissionais que poderiam ser entrevistados. Também, receberam seus trabalhos anteriores devidamente corrigidos para que pudessem evitar os mesmos erros nos trabalhos vindouros.

Uma pequena discussão sobre o que seria feito em relação à entrevista foi iniciada (em que foram levantadas questões como "Com quem falaremos?", "Tem que ser sobre DNA ou pode ser sobre outra coisa?", "Como faremos isso?”, entre outras) e algumas diretrizes foram lhes passadas tais como onde poderiam encontrar pessoas envolvidas na questão do DNA, como deveriam se comunicar com essas pessoas etc. Também, pedimos a eles que escrevessem seus artigos de modo livre, porém com propriedade, e aplicassem as ferramentas aprendidas até o momento.

No decorrer do processo (cerca de dois meses), o grupo selecionou uma lista de pesquisadores, de diversas instituições, e entrou em contato com cada um deles, por email ou telefone, de forma a conseguir tal material. Muitos não responderam às solicitações e outros disseram não ter disponibilidade para uma entrevista, mesmo que feita virtualmente.

Após algumas trocas de mensagens por e-mail (a principal solicitação era que nós interviéssemos na escolha de um profissional e os ajudássemos a realizar a entrevista) e alguns impedimentos (falta de resposta a seus e-mails/telefonemas pelos profissionais, conforme descrito anteriormente, e falta de disponibilidade para chegar até o pesquisador escolhido), decidiram que a entrevista seria feita por computador, via e-mail, pois facilitaria tanto para eles quanto para a pesquisadora selecionada. 
Conseguiram um contato com a professora Maria Denise Fernandes Carvalho ${ }^{3}$, docente e pesquisadora da Universidade Mackenzie, que respondeu a um questionário com 16 perguntas sobre o tema "células-tronco" (tópico escolhido pelo grupo dentro do tema principal).

Dessa forma, e levando em consideração seus conhecimentos previamente adquiridos, redigiram seus artigos. Os artigos foram entregues ao final do prazo marcado e posteriormente corrigidos (ANEXO VI).

\subsubsection{O porquê do tema da entrevista}

As pesquisas com células-tronco estão na mídia leiga há alguns anos por conta de vários experimentos com animais. Já existem trabalhos publicados envolvendo doença de Parkinson, diabetes tipo I, distúrbios circulatórios e doenças neuromusculares; seus resultados, porém, ainda carecem de melhores bases científicas para a utilização rotineira e prática do método (TAKEUCHI; TANNURI, 2006).

Em 2005, o Congresso brasileiro aprovou a Lei Federal $11.105^{4}$ de Biossegurança que regulamentou as pesquisas nessa área e permite o uso de célulatronco embrionária para pesquisa e terapia. Essas células devem ser obtidas de embriões humanos produzidos por fertilização in vitro, não utilizados no procedimento, inviáveis e que tenham sido congelados há mais de três anos. Vale ressaltar que a comercialização de material biológico e a clonagem humana foram proibidas pela mesma lei (TAKEUCHI; TANNURI, 2006). Porém, no mesmo ano, a Procuradoria Geral da República entrou com uma ação de inconstitucionalidade contra a lei. Desde então, os estudos com células-tronco embrionários estavam suspensos no Brasil. A proibição foi baseada no argumento de que dois princípios constitucionais são violados nessa circunstância: o direito à vida e à dignidade dos embriões.

\footnotetext{
${ }^{3}$ Possui graduação em Medicina pela Universidade Federal do Ceará (2001) e mestrado em Ciências Fisiológicas pela Universidade Estadual do Ceará (2004). Doutorado em Genética pela Universidade de São Paulo - USP (2009). Tem experiência na área de Medicina, com ênfase em Genética Médica, atuando principalmente nos seguintes temas: genética clínica, genética, biologia molecular, fibrose cística e sindrome de Down (LATTES).

${ }^{4}$ LEI N ${ }^{\circ} 11.105$, DE 24 DE MARÇO DE 2005 - Regulamenta os incisos II, IV e V do $§ 1^{\circ}$ do art. 225 da Constituição Federal, estabelece normas de segurança e mecanismos de fiscalização de atividades que envolvam organismos geneticamente modificados - OGM e seus derivados, cria o Conselho Nacional de Biossegurança - CNBS, reestrutura a Comissão Técnica Nacional de Biossegurança - CTNBio, dispõe sobre a Política Nacional de Biossegurança - PNB, revoga a Lei no 8.974, de 5 de janeiro de 1995, e a Medida Provisória no 2.191-9, de 23 de agosto de 2001, e os arts. $5^{\circ}, 6^{\circ}, 7^{\circ}, 8^{\circ}, 9^{\circ}, 10$ e 16 da Lei $n^{\circ}$ 10.814, de 15 de dezembro de 2003, e dá outras providências (CASA CIVIL).
} 
Em meados de 2008, a polêmica foi retomada. Alguns cientistas e organizações estavam tentando suspender a proibição do uso de células-tronco para estudos com fins terapêuticos. A mídia explorou toda essa repercussão durante meses e o debate ainda se estendeu durante quase um ano, quando então houve a liberação parcial desses estudos.

\subsubsection{Fase $\mathrm{V}$}

Nessa fase do projeto, já com alguns resultados em mãos, percebemos que o grupo tinha dominado alguns conceitos relativos à divulgação científica. Contudo, ainda apresentavam certas lacunas em relação a eles como, por exemplo, a ordenação sintética de idéias.

Em um novo encontro, debateu-se esse problema e o porquê de ser tão difícil redigir algo considerado, nesse momento, acessível a eles. Com base nessas questões levantadas durante a discussão, resolvemos que seria interessante escrever mais um artigo para que pudessem colocar em prática tudo que tinham aprendido até então.

Dessa forma, após muitos argumentos e discussões ocorridos em duas reuniões, decidimos que o melhor seria fazer uma nova tentativa com um novo tema. Cada um deles escolheu um novo tópico para que redigisse seu artigo. O processo de elaboração seria o mesmo para que não houvesse uma desqualificação do projeto de pesquisa. A diferença deste para os outros artigos esteve no fato de que todo o cronograma foi montado pelo grupo sem qualquer ajuda ou orientação externa, ou seja, mantivemo-nos como observadores nesse momento do estudo. Com isso, embasados em artigos científicos e livros didáticos que eram considerados adequados por eles, os trabalhos foram realizados sem qualquer ajuda por parte de seus orientadores. Todo o processo de escolha, levantamento de dados, escrita e revisão foram feitos exclusivamente pelos alunos do grupo, de forma que pudéssemos avaliar o quanto eles dominavam as ferramentas para a elaboração de artigos de divulgação científica. Os temas escolhidos eram atuais como, por exemplo, a questão da gripe suína ou da Amazônia.

Todo esse processo durou cerca de um mês e meio (desde a reunião até a elaboração final dos artigos) e os artigos foram entregues pessoalmente no prazo estipulado.

Nesse encontro marcado para a entrega, o grupo respondeu a um pequeno questionário com dez questões sobre a escrita do artigo e seu entendimento sobre o assunto da pesquisa em andamento. $\mathrm{O}$ objetivo do questionário foi avaliar suas respostas 
para sabermos se houve ou não apropriação das ferramentas utilizadas para a comunicação escrita. Também, visamos compreender como foi o desempenho deles ao longo do projeto, até essa fase, e como era seu posicionamento em relação a ele (ANEXO VII).

\subsubsection{Temas $x$ momento}

A escolha livre dos temas pelos alunos também foi decorrente do momento em que vivíamos em meados de 2009. A Amazônia era notícia constante por causa do desmatamento cada vez mais intenso na região. A preocupação com o meio ambiente, principalmente em relação ao aquecimento global, era cada vez maior. Outros fatores também foram destacados como a pirataria de animais e a descoberta de novas espécies de plantas que poderiam ser utilizadas no combate a certas doenças.

Outro assunto muito em pauta na época foi a pandemia da gripe suína (Influenza A H1N1). A doença, detectada inicialmente no México no final de março de 2009, espalhou-se por diversos países e causou certo pânico nas populações. As aulas foram suspensas durante certo período por medo de transmissão, já que não havia medicamentos específicos para a doença. Idosos, crianças e gestantes foram aconselhados a se protegerem com mais afinco, pois eram o principal alvo do vírus. Tudo isso repercutiu de forma estrondosa em todos os meios de comunicação e foi abordada durante meses, mesmo após a descoberta de uma vacina que protegeria a população (aplicada no Brasil de abril a junho de 2010).

A riqueza de informações sobre a doença e a constante abordagem da mídia estimularam dois alunos de PIC a escreverem artigos sobre o tema da gripe suína, o que realmente mostra que a TV e alguns outros meios de comunicação influenciam os jovens de todas as formas possíveis.

\subsubsection{Fase VI}

Para melhor verificar o processo de domínio e de apropriação das ferramentas, elaboramos um pequeno projeto em que haveria um processo de transferência de conhecimento entre os alunos do grupo de pré-iniciação científica e os alunos de sua escola. Essa decisão foi tomada após um dos encontros, em que questões como "será que a gente consegue usar isso no dia-a-dia e sem a orientação de outra pessoa?" e 
“acho que o estudo será útil na faculdade, mas como vou saber se entendi tudo?” eram feitas com certa insegurança por parte dos estudantes.

Considerando essas perguntas, chegamos à conclusão que os alunos do grupo sentiam necessidade de colocar em prática todo seu conhecimento e ver se realmente tinham aprendido o necessário, se eram capazes de escrever algo sem que alguém os dissesse como.

Assim, para avaliarmos o quanto eles absorveram de todo o processo, decidimos que seria interessante que usassem o conhecimento aprendido até o momento com outras pessoas, tentando lhes transmitir tudo que foi recebido por nós de modo que seus “pupilos” também conhecessem e, talvez, se apropriassem das ferramentas necessárias à elaboração de artigos de divulgação científica.

Uma nova reunião foi marcada na faculdade e novos direcionamentos, com base nesses objetivos, foram transmitidos a eles. Um cronograma foi definido para esse fim de forma que eles soubessem quais atitudes tomar para desempenhar a tarefa.

O primeiro passo foi conversar com a diretoria da escola, porque as reuniões entre os alunos participantes do projeto deveriam acontecer após o horário escolar. Para isso, elaboraram um Termo de Consentimento que seria enviado para os pais dos alunos escolhidos de modo que ficassem cientes do projeto e da possibilidade de haver gravações ou o uso de imagens na escola. $\mathrm{O}$ consentimento da diretoria foi dado e o projeto foi aplicado na escola de imediato.

Em seguida, cada integrante do grupo deveria escolher um aluno de sua turma ou de outra sala qualquer para participar do projeto. Mais uma vez, a seleção foi feita de modo aleatório, ou seja, o projeto foi explicado nas salas de aulas escolhidas e aqueles que por ele se interessaram participaram de um sorteio, de modo a não haver influência nos resultados.

Com o grupo de seis alunos já organizado, tiveram início as reuniões, que foram registradas em um caderno do grupo (chamado de "Diário de Bordo"). Nesse caderno foram feitas algumas anotações consideradas por eles relevantes como um calendário em que constavam o início e o final do projeto, os nomes dos alunos que fariam parte do grupo, toda a descrição do que aconteceu nos encontros, bem como os termos de consentimento assinados pelos estudantes.

Nas reuniões, os conceitos sobre a divulgação científica e as ferramentas necessárias para a elaboração de artigos foram passados, da mesma forma que o grupoorientador os recebeu. Além disso, o grupo de PIC elaborou um passo a passo (chamado 
de "Cartilha para elaboração de artigo de divulgação científica") contendo conceitos sobre a divulgação científica, como escrever um artigo e alguns artigos escritos por eles durante o estudo.

Depois de receberem as instruções básicas sobre o assunto, os novos participantes tiveram que mostrar o que entenderam elaborando um artigo de divulgação científica de acordo com as especificações dadas, ou seja, dentro do padrão determinado pelo grupo (o mesmo aprendido por eles). O tema escolhido também foi "célulatronco". A justificativa para a escolha desse tópico foi o fato de que o grupo-orientador já tinha pleno domínio do assunto e poderia avaliar de forma mais precisa os artigos recebidos de seus pupilos.

Alguns encontros foram gravados pelos próprios alunos. Com a ajuda de um MP3, as gravações foram feitas em sala de aula e entregues na forma de arquivo digital (o qual não constará deste trabalho). O objetivo disso foi analisar os debates para ver se o que tinham transmitido ao grupo estava de acordo com o que tinham aprendido nas primeiras reuniões.

Os alunos tiveram seus trabalhos corrigidos pelo grupo-orientador, que discutiu junto com eles o tema em questão, assim como a relevância da divulgação científica na escola.

Após a entrega dos trabalhos pelos alunos, o grupo-orientador elaborou um relatório final e o entregou juntamente com os artigos e o diário. Esse relatório foi um breve relato do que significou todo o projeto para eles e como foi transferir um conhecimento adquirido por meio da prática. Todo esse processo durou cerca de dois meses e foi o trabalho final desse grupo de PIC, pois a vigência da PIC terminou em outubro de 2009 (ANEXO VIII).

Dessa forma, com esse material em mãos, poderíamos analisar o desenvolvimento desses alunos em um determinado ambiente e a apropriação das ferramentas necessárias para a elaboração de textos escritos nesse projeto de pesquisa.

Para resumir todo o processo de trabalho, elaboramos uma tabela que abrange todas as etapas. 
Tabela 1. Resumo das atividades realizadas no estudo

\begin{tabular}{|c|c|c|}
\hline Fase & Descrição & Período \\
\hline I & $\begin{array}{l}\text { Questionário com perguntas pessoais aplicado ao grupo de PIC } \\
\text { (ANEXO I) } \\
\text { Questionário com perguntas sobre divulgação científica aplicado } \\
\text { ao grupo de PIC (ANEXO II) } \\
\text { Questionário com perguntas pessoais e sobre ciências (16 com } \\
\text { abordagem geral e } 17 \text { com temas específicos), aplicado aos alunos } \\
\text { da escola estadual em que o grupo de PIC estudava (ANEXO III) } \\
\text { Análise dos dados do questionário aplicado na escola pelos alunos } \\
\text { de PIC }\end{array}$ & $\begin{array}{c}\text { novembro de } 2008 \text { a } \\
\text { janeiro de } 2009\end{array}$ \\
\hline II & $\begin{array}{l}\text { Apresentação do filme "Gattaca - Experiência Genética" e } \\
\text { aplicação de questionário sobre entendimento do filme e } \\
\text { divulgação científica em geral (ANEXO IV) }\end{array}$ & fevereiro de 2009 \\
\hline III & $\begin{array}{l}\text { Elaboração de um artigo de divulgação científica sobre o tema } \\
\text { DNA sem conhecimentos prévios das ferramentas necessárias à } \\
\text { elaboração de um texto desse gênero (ANEXO V) }\end{array}$ & março e abril de 2009 \\
\hline IV & $\begin{array}{l}\text { Elaboração de um artigo de divulgação científica tendo como } \\
\text { base dois pontos principais: } \\
\text { - DNA; } \\
\text { - entrevista com um profissional da área (ou seja, um cientista que } \\
\text { trabalhasse com o tema escolhido). } \\
\text { Nesse momento, os alunos já haviam recebido as instruções } \\
\text { necessárias para a elaboração do artigo de divulgação científica } \\
\text { (ANEXO VI) }\end{array}$ & maio e junho de 2009 \\
\hline $\mathrm{V}$ & $\begin{array}{l}\text { Elaboração de um artigo de divulgação científica, sem } \\
\text { intervenção do orientador, e com escolha livre de tema (ANEXO } \\
\text { VII) }\end{array}$ & julho de 2009 \\
\hline VI & $\begin{array}{l}\text { Mini-projeto em que os alunos de PIC deveriam escolher um } \\
\text { grupo de alunos na escola em que estudavam para transferir seus } \\
\text { conhecimentos sobre a elaboração de artigos de divulgação } \\
\text { científica. O grupo escolhido deveria entregar artigos de } \\
\text { divulgação científica ao grupo de PIC e este deveria analisá-los e } \\
\text { elaborar um relatório final sobre todo o processo pelo qual } \\
\text { passaram durante a pré-iniciação científica (ANEXO VIII) }\end{array}$ & $\begin{array}{l}\text { agosto e setembro de } \\
\qquad 2009\end{array}$ \\
\hline
\end{tabular}




\section{METODOLOGIA DE PESQUISA}

A metodologia de pesquisa adotada é de perfil qualitativo. A abordagem qualitativa surgiu como um contraponto às pesquisas quantitativas que se preocupavam em dividir a realidade em unidades passíveis de mensuração, estudando-as isoladamente (ANDRÉ, 1995). Na perspectiva qualitativa procura-se alcançar uma "visão holística" dos fenômenos, no qual a preocupação com o processo é muito maior do que com o produto, o ambiente natural é a fonte direta dos dados e o pesquisador é o principal instrumento de coleta (LUDKE; ANDRÉ, 1986).

"A observação é chamada de participante porque parte do princípio de que o pesquisador tem sempre um grau de interação com a situação estudada, afetando-a e por ela sendo afetado" (ANDRÉ, 1995, p. 28).

A interação constante entre o pesquisador e o objeto pesquisado é uma forte marca desse tipo de pesquisa na qual "os dados são mediados pelo instrumento humano, o pesquisador” (ANDRÉ, 1995). No entanto, são possíveis vários graus de participação do pesquisador na situação de pesquisa. Junker (1971) define um leque de possibilidades em que a escolha vai desde uma imersão total na realidade até um completo distanciamento. Na participação total o pesquisador se integra ao grupo sem revelar seus propósitos ou sua identidade. Quando o pesquisador participa como observador ele revela apenas parte do que pretende para não alterar o comportamento do grupo observado. Na modalidade observador como participante o pesquisador tem sua identidade e seus objetivos revelados, o que permite acesso a várias informações. E na observação total o pesquisador observa, sem ser visto, como nas câmeras de vigilância, por exemplo. Para manter a clareza da coleta de dados e promover uma análise dos documentos, optamos pelo grau de participação classificado como observador como participante.

Em nosso estudo, seis alunos de uma escola estadual da região de Carapicuíba e integrantes do programa de Pré-Iniciação Científica na Universidade de São Paulo foram acompanhados durante o período de um ano para que pudéssemos observá-los quanto à produção de artigos de divulgação científica.

A escolha da metodologia está relacionada ao contato direto do pesquisador com a situação estudada e com a necessidade de entender o processo de domínio e de apropriação da linguagem da divulgação científica em textos escritos. 


\subsection{Dados}

Consideramos, em primeiro lugar, o nível de conhecimento desses alunos quanto à comunicação/divulgação científica.

Para isso, houve a elaboração de questionários (disponíveis nos Anexos), que continham tanto perguntas gerais quanto relacionadas às Ciências. No total, foram três questionários aplicados, sendo que dois foram respondidos somente pelos alunos de PIC e o outro pelos alunos que estudavam na mesma escola deles.

A segunda fonte de dados considerada foi um questionário avaliador relacionado à exibição do filme "Gattaca".

A terceira, quarta e quinta fontes de dados foram os artigos de divulgação científica elaborados pelos alunos de PIC, que percorreram todo um processo para escrevê-los: o primeiro foi sem uma base total do que era realmente a divulgação científica, o segundo, já com conhecimentos sobre o assunto, foi elaborado com base em uma entrevista e o terceiro foi redigido sem qualquer intervenção e com livre escolha do tema.

A última fonte de dados foi a transposição dos conhecimentos adquiridos durante o estudo para colegas que estudavam na mesma escola e a elaboração de artigos por esses alunos, acompanhados por um relatório feito pelos alunos de PIC.

\subsection{Aplicação da proposta}

Para que a proposta de ensino funcionasse, tentamos elaborar um cronograma em que os alunos desenvolveriam determinadas tarefas. No entanto, por desconhecimento do nosso grupo de pesquisa, uma vez que foram selecionados por meio de um Edital, essas tarefas foram sendo adaptadas de acordo com o desenvolvimento do estudo.

Com a aplicação dos questionários, pudemos conhecê-los melhor, quanto ao conhecimento escolar e cultural, e definimos que grande parte de nosso estudo se relacionaria a artigos escritos de divulgação científica. Assim, definimos como deveriam proceder quanto à elaboração desses textos.

Antes da aplicação da redação de artigos, selecionamos um filme que apresentasse um conteúdo compatível com os conhecimentos dos alunos e que pudesse nos ajudar em nossa proposta de comunicação científica. Também, um questionário relacionado ao filme, do qual poderíamos obter alguns dados pertinentes ao nosso 
trabalho, foi aplicado e serviu para nos nortear quanto ao estabelecimento dos procedimentos que seriam aplicados desse momento em diante.

Na primeira reunião relacionada à tarefa, que seria a elaboração de um artigo de divulgação científica sobre DNA, os alunos foram informados que suas atividades envolveriam a pesquisa, a leitura e a elaboração de um artigo de divulgação científica. $O$ trabalho seria individual e deveria ser entregue dentro de um prazo estipulado. Foram passadas algumas noções do que seria a divulgação, incluindo um site sobre o assunto, porém sem muito aprofundamento. Eles não receberam informações adicionais sobre como deveriam proceder nessa tarefa, ou seja, deveriam descobrir por si só o que era um texto de divulgação e a forma de fazê-lo. Todo o processo durou quase dois meses.

Para a segunda tarefa, os alunos receberam orientações para a realização do trabalho (um artigo de divulgação científica, também sobre o tema DNA, porém baseado em uma entrevista feita com um profissional da área). Além disso, também receberam informações mais aprofundadas sobre o que seriam os artigos de divulgação científica, como poderiam ser feitos, fontes que poderiam ser pesquisadas, profissionais que poderiam ser abordados, bem como as instituições que poderiam conter esse tipo de profissional, de modo que tivessem subsídios para redigi-los do modo mais adequado possível. Também, foram instruídos a montar um pequeno questionário antes da entrevista, para que pudesse norteá-los durante o encontro com o cientista (cabe ressaltar que a escolha do tema da entrevista e as perguntas foram escolhidas somente pelos alunos). Essa fase durou cerca de dois meses.

A terceira tarefa consistiu da redação de um novo artigo de divulgação científica, contudo, sem intervenção quanto aos procedimentos de elaboração e ao tema escolhido (dessa vez, os alunos puderam escolher sobre o que gostariam de escrever). Essa atividade visou avaliar o modo como esses alunos desenvolviam sua metodologia para elaborar um texto, sem a necessidade de um orientador, usando as ferramentas necessárias para esse fim. Ao final, eles responderam a um questionário que, para nós, avaliou, de certa forma, o nível de aprendizado desses alunos. O processo durou um mês, pois estavam em período de férias.

$\mathrm{Na}$ quarta e última tarefa, os alunos do grupo deveriam tentar transpor seus conhecimentos para colegas da escola em que estudavam. Decidimos que o ideal seria que cada um deles tivesse apenas um colega sob orientação, devido ao prazo curto que possuíam. Assim, sortearam seis alunos na escola (que se inscreveram para esse miniprojeto) para o estudo. Nosso grupo foi orientado a seguir as diretrizes aprendidas no 
decorrer do estudo para que pudessem passá-las aos colegas da forma mais adequada possível. Eles deveriam fazer com que seus "alunos" redigissem artigos de divulgação científica individuais, da mesma forma como o fizeram, e avaliar, na forma de um relatório, como foi esse processo de transposição de conhecimento. Dedicaram-se a esse pequeno projeto durante dois meses e, ao final, todo o material foi entregue aos orientadores.

\subsection{Coleta dos dados}

A coleta de dados ocorreu de outubro de 2008 a outubro de 2009, totalizando doze (12) meses, que foi o período estipulado para o projeto de PIC. A conveniência em fazer um acompanhamento dos estudantes em um intervalo de tempo razoavelmente longo residiu no fato de que o grande número de eventos foi por nós presenciado e orientado, o que facilitou nosso entendimento sobre o domínio e a apropriação das ferramentas necessárias para elaboração de artigos de divulgação científica por esses alunos. Também, foi possível averiguar os alunos na produção de textos científicos de natureza diversificada, o que seria impossível em um tempo menor.

Os ambientes de registro ocorreram nas salas de aula e no laboratório de Química da Faculdade de Educação em encontros quinzenais devido à questão de mobilidade dos alunos, uma vez que a distância era grande e o horário restrito. Somente a última fase ocorreu nas dependências da escola em que estudavam, com o consentimento da diretoria da escola.

A metodologia escolhida partiu do fato de que o contato direto do pesquisador com a situação estudada permite reconstruir os processos e as relações que configuram a realidade estudada (ANDRÉ, 1995). A observação participante, segundo André, torna possível "documentar o não-documentado", objetivo de nosso estudo: entender o processo de domínio e de apropriação das ferramentas necessárias para construir textos de comunicação científica pelos participantes do processo.

Para estruturar nossa metodologia de pesquisa, levamos em consideração a forma mais adequada de registro de modo a ser possível a análise e o estudo dos meios de apropriação e transcrição de conhecimentos. Assim, a escolha do registro por meio de redações de artigos de divulgação científica foi a que mais se adequou às nossas necessidades, uma vez que observaríamos o desenvolvimento desses alunos, que adquiriram certos conhecimentos, principalmente o da linguagem científica, por meio da 
escrita. Ademais, isso nos propicia uma forma de aprofundar o olhar em relação a diversos aspectos que possam ser identificados em uma coleta de dados.

Todos os artigos foram entregues tanto na forma virtual quanto impressos, o que facilitou seu manuseio na avaliação.

Todas as atividades do projeto foram programadas de acordo com as necessidades do projeto, definidas após cada reunião, nas quais dúvidas eram abordadas, e dos alunos em relação ao seu crescimento científico. De acordo com Lemke (1998a), a estrutura de uma atividade é tão importante quanto o diálogo que se estabelece em uma sala de aula, pois a partir dela pode-se identificar a forma como se ensina e como se aprende o conteúdo de Ciências. Com isso, tornou-se extremamente importante planejar todas as atividades, pois a linguagem científica envolve uma maior dificuldade, já que os alunos não estão familiarizados com muitos dos termos encontrados em textos diferentes dos didáticos.

Em relação à análise dos dados, alguns pontos foram levados em consideração como fatores lingüísticos, estrutura e, principalmente, o nível de domínio e de apropriação das ferramentas relevantes à redação de um artigo de divulgação científica. O propósito da análise é organizar os dados, extraídos de material bruto a partir das categorias que têm significado específico e estritamente ligado à natureza das informações que se quer obter (PACCA; VILLANI, 1990).

Levando em conta o objetivo do trabalho, consideramos o quanto esses alunos se apropriaram das ferramentas, analisando seus artigos e discorrendo se a divulgação é uma forma de aprendizagem que realmente faz a diferença no desenvolvimento cultural e científico do aluno.

Todos os dados coletados foram analisados, de alguma forma (algumas das respostas dadas aos questionários, escolhidas de acordo com nossa necessidade, foram analisadas para nos dar subsídios quanto a seu aprimoramento), porém os textos escritos foram o foco de nosso estudo tendo por objetivo responder à pergunta de nossa pesquisa. 


\section{RESULTADOS E DISCUSSÃO}

Para apresentação dos dados, organizamo-los de acordo com as fases dentro do estudo. Conforme afirmado anteriormente, nem todos os dados obtidos durante o estudo foram analisados. Focamos especialmente os artigos escritos para identificarmos o processo de internalização, de domínio e de apropriação do conceito da ferramenta. Também consideramos as respostas dos alunos nos questionários aplicados durante o estudo para definirmos algumas linhas de pesquisa dentro da metodologia. Com esses dados em mãos, pudemos investigar o caminho percorrido por eles, desde o momento das reuniões até a entrega dos textos.

\subsection{Fase I}

Conforme descrita anteriormente, a Fase I consistiu da aplicação de três questionários: um questionário com perguntas pessoais para conhecer o grupo de PIC, outro com perguntas gerais sobre a divulgação científica, também respondido pelo grupo de PIC, e um no qual constavam perguntas gerais e específicas sobre o tema Ciências e que foi aplicado na escola em que estudavam.

O objetivo dessa fase foi saber qual o nível de conhecimento científico, tanto dos alunos de PIC quanto dos alunos pertencentes ao seu ambiente, e qual sua postura em relação ao assunto. Ademais, interessava-nos conhecer um pouco sobre os alunos com os quais trabalharíamos para reconhecer, principalmente, quais eram seus conhecimentos prévios sobre assuntos atuais como, por exemplo, o aquecimento global.

A necessidade de escolha de um tema que deveria ser desenvolvido por quase todo o estudo era de extrema relevância. O intuito era acompanhar todo o processo de internalização das ferramentas necessárias à construção de textos de divulgação, desde a sua pesquisa até a escrita do texto, tendo como base o tema escolhido.

Para chegarmos à escolha deste, optamos por utilizar alguns critérios que nos ajudaria a defini-lo, ou seja, a seleção de algumas questões respondidas pelos alunos da escola em que o grupo de PIC estudava. Como o estudo utiliza a linguagem de divulgação científica, escolhemos algumas perguntas que poderiam influenciar a obtenção de conhecimento e outras que estivessem mais relacionadas às ciências, principalmente aquelas que chamaram a atenção quanto às respostas. Abaixo estão as perguntas e algumas considerações. 


\section{- Tem acesso à Internet? O que costuma acessar?}

Selecionamos essas questões para saber, principalmente, qual era o tipo de interesse desses alunos. Ao analisarmos os questionários, verificamos que $99 \%$ dos alunos tinham acesso a esse meio e que navegavam, em média, de duas a cinco horas por dia. Os principais sites acessados eram os de relacionamento, como Orkut, e o MSN, entre outros. Os sites de pesquisa foram os menos citados. Com essas respostas, podemos inferir que a grande maioria tem acesso a esse meio de comunicação, o qual pode fornecer informações de grande valia sobre o assunto "ciências". No entanto, é fato que ele é usado para diversão em grande parte do tempo, sendo usada para fins de pesquisa somente quando necessário (ou seja, em caso de trabalhos escolares).

\section{- Costuma ler? O que costuma ler? Freqüenta a biblioteca}

Outras questões que nos ofereceram uma idéia do hábito da leitura desses alunos: $60 \%$ têm o hábito da leitura, porém, quando indagados sobre o que lêem, a maioria indica revistas e gibis. Os livros são citados, porém com menos freqüência (cerca de 40\%). Em relação à biblioteca, somente 12,5\% freqüentam-na. Quando perguntados sobre o porquê de não a freqüentar, uma grande maioria responde que é por falta de interesse ou de tempo.

Encontramos mais um ponto de desinteresse no que se refere ao acúmulo de informações, o que pode dificultar a aprendizagem desses alunos tanto em âmbito cultural quanto escolar. Infelizmente, hoje em dia, a leitura é pouco estimulada pelos pais e até mesmo pelos professores, podendo causar um déficit considerável no nível de conhecimento e, posteriormente, prejudicando na formação de vocabulário, na compreensão de textos, na apropriação de conceitos e no desenvolvimento da escrita por parte dos alunos.

\section{- Você se interessa pelo tema "ciências"?}

Essa foi uma pergunta que nos ajudou a perceber o quanto as ciências podem influenciar suas vidas. $53 \%$ dizem se interessar pelo tema, embora a maioria das respostas indique uma idéia vaga do por que, pois responderam "que gostavam porque era interessante". Quando indagados sobre onde se informavam pelo tema, a maioria citou a Internet (aproximadamente 80\%).

- Tem diferença entre as ciências aprendidas na escola e fora da escola?

Essa foi uma questão interessante, pois $56 \%$ acham que há diferença entre elas e, dentro desse total, uma grande parte dos alunos associa a ciência fora da escola à 
tecnologia. Ademais, quando perguntados sobre o que as ciências significam para eles, a maioria dos entrevistados cita o estudo do corpo humano e do meio ambiente como principal assunto associado a elas. Isso nos mostra que a ciência, para esses alunos, se limita àquela aprendida nos livros didáticos, isto é, está relacionada ao conteúdo estudado na disciplina de ciências.

\section{- Onde você mais ouve falar sobre ciências?}

Quase todos responderam escola e televisão (aproximadamente 90\%), embora alguns achem que essas fontes de informação sejam insuficientes. Cabe ressaltar que uma parte dos alunos acredita que a televisão transmita somente verdades (ou fatos mais aprofundados) sobre as ciências. Pouquíssimos responderam que buscam informações em jornais ou livros, corroborando com a afirmação acima de que há certo desinteresse em relação ao assunto. Uma coisa interessante é que, quando perguntados se gostavam do tema ou das aulas de ciências, a maioria dos entrevistados disse que sim. Isso nos leva a pensar: qual o motivo de desinteresse desses alunos?

Cabe esclarecermos que o questionário foi considerado de relevância parcial em nossa pesquisa. Selecionamos apenas algumas questões que poderiam servir de apoio a nosso estudo e somente nessa fase do projeto.

Ao analisar esses dados, tivemos a iniciativa de empregar uma metodologia em

que o aluno tivesse que se dedicar à leitura, se apropriar de certo conhecimento e transpô-lo de modo a fazer com que outras pessoas o entendessem, criando assim uma cadeia de informações. Assim, concluímos que a elaboração de artigos de divulgação científica seria uma forma de abranger todas essas ferramentas, além de introduzi-los no mundo das ciências.

\subsection{Fase II}

Nessa fase, a escolha do tema já estava definida: DNA. Assim, escolhemos o filme "Gattaca - Experiência Genética", que fala principalmente sobre o código genético (DNA) e suas aplicações em um mundo futuro. O filme foi exibido para o grupo de PIC e, ao seu término, um questionário foi aplicado para que pudéssemos saber o quanto eles tinham absorvido do filme e se tinham entendido a sua relação com a divulgação científica. No questionário com dez perguntas, destacamos quatro, cujas respostas nos direcionaram para a tomada de decisões quanto ao passo seguinte do 
projeto. Enfatizamos que o questionário não continha o nome dos alunos e, por isso, os nomearemos como ALUNO ${ }^{\circ} \#$.

“Você acha que é possível entender o que é DNA apenas assistindo ao filme? Por quê?"

(ALUNO 1): "Talvez não, pois apesar de demonstrar como seria, ou melhor, como é, é algo vago que não mostra realmente como é o DNA".

(ALUNO 2): “Não, com o filme se pode ter uma noção sobre o que é, mas não muita coisa, pois no filme mostra um certo avanço tecnológico que não é a nossa realidade de hoje, mas sim do futuro”.

(ALUNO 3): "O básico eu acredito que sim, porque no filme, apesar de mostrar do que o DNA é capaz, mostra algumas coisas que ainda não reais”.

(ALUNO 4): "Um pouco, pois no filme fica bem claro que o DNA é único/intransferivel e que guarda todas suas informações genéticas, porém é somente isso que ele mostra”.

(ALUNO 5): "Dá para se ter uma pequena noção, como entender que o DNA é o material genético da pessoa, que possui todas suas características, além do mais é algo único. Porque é um filme fictício e nem tudo o que foi apresentado é verídico”.

(ALUNO 6): “Entender tudo, não. Há coisas no filme que são duvidosas, porém dá pra entender que o DNA é único de pessoa para pessoa e que ele contém informações importantes para elas (informações que nem sempre são 100\%)”.

As opiniões foram muito parecidas e vagas em relação ao assunto. Cinco deles acharam que o filme dá alguma noção sobre o assunto enquanto apenas um achou que não, embora a justificativa não tenha sido muito precisa. Vale salientar que, ao ler as respostas, fica claro o fato de que há um conhecimento prévio sobre o tópico do filme, embora muito limitado. Também, há o fato de que quatro desses alunos ainda não haviam tido a matéria “Genética” em seu currículo escolar, pois eram do $2^{\circ}$ ano.

“Qual material você pesquisaria para saber mais sobre o código genético?”

(ALUNO 1): “Artigos, pesquisas, trabalhos realizados antes e atuais para saber o que ele realmente é".

(ALUNO 2): "Usaria a Internet, um livro no qual falasse sobre a genética, pediria ajuda e informações aos professores do ramo e usaria revistas sobre o assunto".

(ALUNO 3): “A Internet, livros, revistas, professores". 
(ALUNO 4): "Livros, Internet e revistas relacionadas ao assunto. Como no exemplo de uma revista que vem dentro do jornal, o Estado de São Paulo, que traz informações/curiosidades, e uma delas foi o DNA".

(ALUNO 5): "Livros didáticos de ciências, Internet e pesquisas feitas por cientistas".

(ALUNO 6): "Livros sobre DNA, alguns documentários e filmes e professores e pessoas que entendem do assunto".

As fontes citadas foram várias, mas a Internet esteve em quase todas. Embora tenham citado livros e artigos científicos, nota-se claramente, pelas respostas do questionário como um todo, que isso não acontece usualmente. Na verdade, o que se percebe nas respostas é o pouco conhecimento das ferramentas que podem ser utilizadas para realizar uma tarefa desse nível.

"Que fontes você acha que foram usadas para o tema em questão?” (ALUNO 1): "Fontes como a reduplicação do DNA, clonagem, etc.".

(ALUNO 2): "Muitas pesquisas sobre genética e tecnologia”.

(ALUNO 3): “Acredito que com base em algumas pesquisas, cientistas, revistas, Internet, entre outros".

(ALUNO 4): "Pesquisa em livros, Internet e revista e muita imaginação, pois acaba demonstrando um futuro em que está distante de nós, coisas que estão muito longe para acontecer".

(ALUNO 5): "Estudos baseados em experiências feitas. Como, por exemplo, a fertilização artificial e os estudos e pesquisas feitos sobre DNA”.

(ALUNO 6): "Documentários, professores e pessoas que estudaram sobre o tema, artigos e livros".

Alguns citaram livros, artigos etc. enquanto outros disseram profissionais da área. Duas respostas apontaram falta de conhecimento sobre quais fontes poderiam ser buscadas para tal intento. No geral, eles têm alguma noção das fontes que poderiam ser pesquisadas, porém sem levar em consideração o que poderia ser ou não mais confiável.

“Em sua opinião, o filme é uma forma de divulgação científica ou apenas um instrumento de entretenimento? Ajudaria em uma aula de Biologia? Justifique.”

(ALUNO 1): "É uma forma de divulgação científica, com certeza ajudaria, porque além de acrescentar conhecimento, pode até mesmo despertar o interesse dos alunos para o determinado tema”. 
(ALUNO 2): "É uma forma de divulgação, pois ele transmite muitas informações importantes. Ajudaria um pouco, pelo menos assistindo ao filme se pode ter uma base sobre genética, e isso é bom”.

(ALUNO 3): "O filme pode sim ser uma forma de divulgação científica, até porque a partir do filme pode-se despertar na pessoa o interesse pelo assunto abordado. Acredito que ajudaria em aulas de biologia, mostra mais o básico, mas dá para se ter uma noção".

(ALUNO 4): "Os dois, um pouco, pois apesar de mostrar um pouco de DNA (o básico) no plano de fundo da história há um enredo que envolve amor, superação..."

(ALUNO 5): "Ele é ao mesmo tempo uma forma de divulgação cientifica por falar do DNA e oferece entretenimento por causa da história de amor e superação. Ajudaria a ter uma noção do que é o DNA e o que ele representa, como ter nossas características nele”.

(ALUNO 6): "Pode ser uma divulgação científica. Ajudaria em aulas de biologia pois os fatos desse filme serão baseados em informações pesquisadas para deixar o filme o mais real possível. Mas tem que tomar cuidado com os fatos se são verídicos ou não".

Todos afirmaram que o filme era uma forma de divulgação científica e que poderia ajudar a ilustrar uma aula, pois continha informações básicas sobre o assunto. $\mathrm{O}$ que se percebe aqui é que eles não têm um embasamento para afirmar o que seria uma divulgação científica. Somente o ALUNO 2 se aproximou do que seria uma definição sobre divulgação científica.

Cabe ressaltar que até esse momento eles ainda não tinham recebido informações sobre o que seria a divulgação científica tampouco como seria o projeto. Portanto, os conceitos por eles apresentados foram adquiridos previamente. Isso nos leva a considerar que é necessário trabalhar informações atualizadas sobre ciência e tecnologia e esclarecê-las em relação ao meio em que aparecem para elucidar possíveis dúvidas e viabilizar a formação do aluno enquanto indivíduo crítico e reflexivo. Assim, consideramos que o contato com textos alternativos, sejam eles de jornais ou revistas, desde que com abordagens contextualizadas, pode ajudar a despertar o interesse por parte dos alunos em conhecer e até mesmo produzir contextos de aprendizagem. De acordo com Rego (1995), o uso de mediadores externos (ferramentas), como um instrumento ou uma figura, e também internos, como signos (objeto, forma, gesto, figura ou som), aumenta a capacidade de trabalhar as funções mentais (ou cognitivas) 
superiores. Para haver um desenvolvimento do ser humano, é necessária a internalização do conhecimento, ou seja, deve haver uma transformação dos processos externos realizados socialmente, criando e formando processos internos individuais (REGO, 1995). Logo, a comunicação, seja ela oral ou escrita, envolve diversos aspectos como linguagem, ação, gestos e relações pessoais (MACHADO, 1999).

Outro ponto de destaque, que realmente nos interessa, é o fato do pouco uso de uma linguagem científica. Os termos usados por eles são comuns e não denotam qualquer contato com uma linguagem mais específica. Com isso, entendemos que nossos alunos precisariam de um embasamento muito bem aplicado para que pudessem desenvolver uma atividade escrita que atendesse, pelo menos, à parte de nossas expectativas.

\subsection{Fase III}

Esta fase consistiu da elaboração de um artigo de divulgação científica tendo como tema o DNA. Nas reuniões que ocorreram no período, solicitamos ao grupo que produzissem um texto, baseado no tema escolhido, e considerassem o modo como esse texto seria abordado na mídia, isto é, que apresentasse os fundamentos, os objetivos e a relevância da pesquisa nele descrita e fosse direcionado a um leitor que não soubesse coisa alguma sobre o assunto abordado. Contudo, antes de fazer isso, deveriam pesquisar o que seria a divulgação científica e como era seu padrão, de que forma escrevê-la, as bases para sua elaboração. Algumas instruções e sites foram passados a eles, como, por exemplo, o do Núcleo de Divulgação Científica José Reis, porém com pouco aprofundamento, instigando-os na busca pelo desconhecido. Além disso, permitimos que os estudantes se posicionassem quanto ao assunto de forma livre. Essa condição foi baseada no trabalho de Oliveira (2001), que verificou que essa liberdade aumentou o interesse de alguns alunos pela escrita, levando-os a expor os conteúdos estudados com mais facilidade. O principal objetivo era saber se eles tinham absorvido algo de nossas conversas, se seguiriam as diretrizes passadas a eles, mesmo que em pouco número, e se conseguiriam se apropriar ou não dos conceitos que deveriam aprender por meio de pesquisas para tal tarefa. Também buscamos identificar os possíveis elementos que relacionassem a escrita com a interpretação desses conceitos obtidos por meio de pesquisas. É importante salientar aqui que a intervenção foi mínima: limitou-se ao tema escolhido anteriormente, à indicação de alguns sites sobre 
divulgação científica e a instruções relacionadas à comparação entre um artigo científico e um de divulgação científica.

Quase todos os artigos foram entregues no prazo estipulado e posteriormente corrigidos. A correção teve como ponto principal o emprego de uma linguagem científica específica do assunto, além do gênero usado e a organização das idéias. Itens como coerência, ortografia, conteúdo, estrutura e fontes pesquisadas também foram considerados na análise, porém em menor proporção.

O artigo do aluno Pedro teve que ser descartado, pois foi entregue bem depois do prazo, ou seja, poderia influenciar no estudo, já que o aluno o fez depois da reunião em que houve certos esclarecimentos sobre o estudo.

Um fato interessante sobre a estrutura dos textos é que todos eles eram semelhantes a um artigo científico, ou seja, apresentavam um item ou mais pertencente ao artigo científico como, por exemplo, resumo, introdução etc. O título foi algo que também chamou a atenção: quatro deles tinham "DNA" como nome do trabalho, o que nos remete a pensar que não se preocuparam em entender, até esse momento, como funciona a questão da "chamada científica" para esse tipo de artigo.

"Valorizar os adeptos descobrimento da ciência, tais como o desenvolvimento da genética, encontramos um ser ainda muito desconhecido, um tanto antigo e muito discutido suas relações hoje, o DNA”. [...]

“[...] Segundo o laboratório Diagenix, o exame de paternidade é um dos recursos mais utilizados pela Justiça hoje, a partir de técnicas que empregam o exame do DNA." [...]

Esses trechos extraídos de dois dos seis textos têm um ponto em comum: são muito parecidos com trabalhos escolares em que o "copiar e colar" de livros, ou mesmo de Internet, foi utilizado sem pensar em suas implicações. Além disso, é visível o uso de alguns termos relacionados à linguagem científica, porém sem propriedade alguma apenas uma cópia sem significado.

De acordo com Vygotsky, para que o processo de internalização ocorra, dois aspectos devem ser considerados: o percurso da internalização das formas culturais pelo indivíduo e a criação da consciência pela internalização, salientando que esse processo não é o de uma cópia dos conteúdos da realidade objetiva para o interior da consciência. Assim, a formação da consciência se dá quando ele usa as ferramentas de mediação para a construção de um conhecimento - o que definitivamente não acontece quando os alunos usam de "artifícios" para esse processo. 
Todos os textos apresentaram muitos erros ortográficos e gramaticais, principalmente relacionados à concordância e à coerência.

"O mais importante é que foi constatadas uma associação direta entre diferenças epigenéticas notáveis e a idade dos gêmeos univitelinos". [...]

"Há alguns anos atrás começou a estudar uma molécula ainda no entanto desconhecida..."

Não sabemos se essa deficiência está relacionada à introdução de novas palavras, uma vez que o contato com textos científicos ainda é primitivo, ou à falta de conhecimento da língua materna, porém, como essa questão não é foco de nosso trabalho, não a abordaremos adiante.

Em relação ao conteúdo, é fato que não houve um aprofundamento do assunto, ou seja, os textos abordavam o básico sobre o DNA. Isso atesta que a pesquisa não foi fundamentada em artigos científicos, portanto, prejudicando também a apropriação de termos científicos.

Outra questão foram as fontes pesquisadas: todas eram da Internet, mas nenhum artigo científico constou da lista, tampouco locais confiáveis como universidades, organizações governamentais etc. Sua organização também foi deficiente, o que demonstra nenhum contato com esse tipo de construção.

O que se percebe ao ler os textos é que, além da falta de conhecimento sobre o assunto escolhido e sobre o modo como a divulgação científica ocorre na mídia, especialmente em sua forma escrita, a leitura e a prática de pesquisa não fazem parte do cotidiano desses alunos. $\mathrm{O}$ artigo que mais se aproximou de nosso objetivo foi o do Pedro, que apresentou uma linguagem mais adequada ao tipo de trabalho proposto. No entanto, o trabalho não pode ser considerado, já que foi entregue posteriormente à data prevista.

Em um de seus trabalhos, Sacanore (1983) mostrou como o conhecimento adquirido através de experiências em leitura e escrita dos aprendizes era compartilhado e contribuía para o desenvolvimento de conteúdos específicos. Segundo o autor, ao encorajar os estudantes a identificar e escrever vários tipos de textos, os professores estariam ajudando-os a entender o processo de construção de sentidos. $\mathrm{O}$ ensino, nesse sentido, foi com isso compreendido como uma atividade de gerar, organizar e revisar idéias trazidas pelo texto de diferentes origens, e somado às experiências dos leitores e escritores (ROTTAVA, 1999) 
Analisando essas correções e considerando as ações dos alunos em relação ao contexto em que ocorrem, ficou evidente que até esse momento a apropriação de conceitos e ferramentas ainda não tinha ocorrido, ou seja, não conseguiram agir por conta própria sem a ajuda de um intermediário, no caso, seu professor ou seu orientador. Com base nessas observações, podemos concordar com Tilstra (2001) em relação à necessidade dos estudantes passarem por um processo de ensino, onde inicialmente aprendem a construir as várias partes de um texto, ou seja, devem dominar a forma composicional dos gêneros do discurso.

Entendemos também que ocorreu certa dificuldade na interpretação do material que deveria ser utilizado como base para a tarefa, ou seja, fontes de divulgação científica. A partir da ação mediada descrita por Wertsch, que se define pelo uso de ferramentas culturais ao mesmo tempo em que delineia uma visão de cognição enquanto "pensar-com-ferramentas" culturais, ficou evidente que não houve uma interação entre o indivíduo e a ferramenta, o que proporciona essa lacuna no momento de produzir o artigo de divulgação científica.

Apesar de todos esses indicadores, podemos observar que, de modo geral, tivemos um saldo positivo nessa fase: embora tenham expressado uma relação superficial com o objeto de estudo e quase nenhuma apropriação ou domínio das ferramentas, e se considerarmos que não tiveram uma orientação aprofundada anteriormente ou mesmo a sistematização do processo pelo qual deveriam passar, ainda assim conseguiram redigir um texto, o que pode demonstrar que a capacidade desses alunos de se comunicarem por escrito pode ser desenvolvida.

Logo, é evidente a necessidade desses alunos de seguirem um processo de aprendizagem para que possam construir seus textos parte a parte e aplicar os vários gêneros de discurso de modo a deixá-los adequados à leitura de uma pessoa leiga.

\subsection{Fase IV}

Após a correção do primeiro artigo, uma nova reunião foi marcada com o intuito de esclarecer os erros cometidos e de passar um embasamento mais histórico e teórico sobre o que seria a divulgação científica e como elaborar artigos com essas características. Assim, depois de sanar suas dúvidas quanto ao assunto, passamos para a próxima fase do trabalho: a elaboração de um novo artigo de divulgação baseado em uma entrevista com um profissional da área. 
O objetivo dessa fase era que os alunos entrassem em contato com profissionais da área para entender melhor o tema com o qual estavam trabalhando e conhecer um pouco mais sobre ele, reconstruindo seus conceitos científicos para que se tornassem mais críticos. Também, com base na entrevista e na conversa com um pesquisador da área, talvez fosse possível que assimilassem as ferramentas necessárias para a construção de um artigo que apresentasse características científicas, principalmente em relação à linguagem.

Para a entrevista, solicitamos a eles que estudassem mais sobre o tema DNA de modo que pudessem elaborar questões fundamentadas em teorias aceitas até então. Pedimos que pesquisassem sobre o assunto e consultassem, inclusive, artigos científicos de revistas e jornais bem conceituados no mercado. O ideal é que se interassem do conteúdo o máximo possível para que pudessem colocá-lo no papel com mais propriedade e mostrassem se a linguagem científica faria parte desse novo vocabulário.

Nessa fase, nossa intervenção foi mais marcante. Direcionamo-los quanto ao que deveriam estudar e sobre quem deveriam procurar, além de reforçar os pontos que deveriam ser destacados em seus artigos como, por exemplo, a estrutura e as fontes de pesquisa.

Sem qualquer orientação em relação às perguntas, os alunos montaram o questionário direcionado ao profissional e esse foi um instrumento que nos mostrou se estavam desenvolvendo suas capacidades de interpretação e escrita.

A entrevista foi feita por e-mail e, baseados nas respostas da pesquisadora, mais o que haviam adquirido de conhecimento sobre o assunto, por meio de livros, artigos, entre outros, escreveram seus artigos. Dessa vez, dentro do tema estipulado, selecionaram o tópico sobre "células-tronco" para trabalhar, o que tornaria o estudo mais aprofundado.

Todo esse processo nos revelou que o desenvolvimento desses alunos, embora muito lento, era crescente. As perguntas foram bem elaboradas e algumas delas apresentavam caráter argumentativo, o que nos leva a perceber que o processo de internalização e o conceito ferramenta-indivíduo pareceu estar em fase de apropriação por parte de alguns desses alunos. No entanto, ao analisar os textos, percebemos que somente três desses estudantes estavam respondendo de modo positivo até o momento.

Nessa verificação, constatamos que as alunas Simone, Soraia e Carla ainda estavam presas às questões didáticas e, embora utilizassem uma linguagem um pouco mais próxima da de textos científicos, continuaram a usar estruturas com gênero 
didático, ou seja, uma estrutura parecida com a de um trabalho escolar como, por exemplo, a descrição de conceitos. Também é perceptível a semelhança entre eles. Para ilustrar essa constatação, transcrevemos alguns trechos de seus textos (na ordem citada acima):

\section{Trecho 1}

“As células-tronco são classificadas de acordo com a sua potencialidade, ou seja, significa dizer que nem todo tipo de células-tronco tem a mesma capacidade de diferenciação. Elas são classificadas da seguinte maneira:

- $\quad$ Totipotentes: São células que tem a capacidade de dar origem a qualquer tecido do corpo, sem exceção.

- Pluripotentes: São as células capazes de dar origem a todos os tipos celulares de um embrião, com exceção da placenta e anexos.

- $\quad$ Multipotentes: São capazes de produzir diversificados tecidos.

- $\quad$ Oligopotentes: Células com uma capacidade reduzida de originar outros tecidos, mas ainda assim os originam, mesmo que pouco.

- Unipotentes: Células capazes de originar um único tecido do corpo."

\section{Trecho 2}

“Células-tronco embrionárias são encontradas no embrião, já as células adultas são encontradas em tecidos que já se desenvolveram, tais como placenta, polpa de dente, gordura de lipoaspiração, entre outros. Elas são classificadas em 5 tipos que são: Totipotentes: são células-tronco que conseguem se diferenciar em todos os 216 tecidos que formam o corpo humano, inclusive placenta e anexos embrionários. É o caso de Zigoto (óvulo fertilizado); Pluripotentes: são as que conseguem se diferenciar nos tecidos provenientes dos três folhetos embrionários (ectoderme, endoderme e mesoderme). Ex. Células da Massa Interna de um Embrião de 5-6 dias; Multipotentes: capazes de originar diversos tecidos; Oligopotentes: capazes de originar poucos tecidos; Onipotentes: capazes de se diferenciar em um único tecido."

\section{Trecho 3}

“Todas essas células possuem suas funções especificas como exemplo ás células tronco adultas tem como finalidade repara qualquer lesão ou dano causado ao tecido de origem,No entanto realçamos que alguns tecidos possuem poucas células tronco 
adultas, e precisam recrutar de outras fontes, isso ocorre o processo da lesão o que aconteça é que essas células não correspondem prontamente ao dano deste tecido;Uma outra característica especial das células tronco é a sua auto - renovação,ou seja elas podem criar copias de si mesmas, garantindo uma reserva ás células com capacidade de reparo devido á essa característica muitas dessas células são utilizadas na aplicação terapêutica.

Além das células tronco serem dividas entre células tronco embrionárias e células tronco tronco adultas são dividas em um outro subgrupo,classificadas com base no seu potencial de diferenciação ou origem,sendo elas:

1. Totipotentes: são células-tronco que conseguem se diferenciar em todos os 216 tecidos que formam o corpo humano, inclusive placenta e anexos embrionários. É o caso de Zigoto (óvulo fertilizado);

2. Pluripotentes: são as que conseguem se diferenciar nos tecidos provenientes dos 3 folhetos embrionários (ectoderme, endoderme e mesoderme). Ex. Células da Massa Interna de um Embrião de 5-6 dias;

3. Multipotentes: capazes de originar diversos tecidos;

4. Oligopotentes: capazes de originar poucos tecidos;

5. Unipotentes: capazes de se diferenciar em um único tecido."

Um detalhe deve ser observado: o trecho 3, que pertence à aluna Carla, apresenta, além das características didáticas, indícios de ter sido "copiado e colado" de algum site da Internet. Isso fica evidente pelos erros que aparecem no texto, o que demonstra que a aluna não o leu ou, se o fez, não soube como estruturá-lo de modo adequado.

Já os alunos Pedro, Andressa e Mônica assumiram uma postura mais argumentativa e objetiva, utilizando termos mais comuns em textos de caráter científico, mas que possam ser entendidos pelo leitor do texto. Abaixo estão exemplos que confirmam isso:

\section{Trecho 1}

“Células-tronco. Ao tocar neste assunto se desencadeiam várias discussões, dentre elas críticas, manifestações positivas e negativas. Vários setores da sociedade são a favor e outros são contra. Porém, o maior problema não é a discussão entre os que são contra ou a favor, mas sim, é quando esse tema é discutido sem um mínimo de informação. 
Por isso é importante que antes de criarmos uma opinião devemos antes pesquisar sobre o que é, de onde vem, por que são tão importantes e etc.. Mas pesquisar de verdade! Em fontes confiáveis e não somente em uma, para saber compreender as diversas formas com que o tema [células-tronco] é apresentado, entender a opinião dos demais grupos sociais e criar uma própria opinião que seja fortemente fundamentada."

\section{Trecho 2}

“As pesquisas com células-tronco, ou seja, células capazes de dar origem aos mais diversos tecidos com osso, cartilagem, nervos, músculos, dentre outros, tiveram um grande avanço nesses últimos anos, porém ainda tem quem ache que é uma afronta a vida do modo que ela é. Muitas das pessoas que são contra o uso de células-tronco são ligadas a entidades religiosas ou não têm informações suficientes para entender o assunto em toda sua extensão."

“Enfim, as pesquisas com células-tronco, sejam elas quais forem, estão a todo vapor, apesar de alguns empecilhos creio que quando estiverem concluídas será apenas mais um passo para ciência que avança mais e mais todos os dias, porém para a sociedade será uma evolução inigualável."

\section{Trecho 3}

"Atualmente é de demasiada importância manter a sociedade informada sobre o que ocorre no campo da ciência. Esta informação precisa chegar de uma forma correta, separando o mito da realidade. Um dos temas mais debatidos mundialmente, inclusive no Brasil, são as pesquisas com células-tronco."

“Em muitos países as pesquisas com este tipo de célula já foram autorizadas, é o caso da China, Israel, Reino Unido e Cingapura. No Brasil é autorizada a manipulação dos embriões descartados, permitido por a Lei 11.105 de Biossegurança em 2005.

Os E.U. A é um dos líderes de pesquisas com células-tronco, entretanto proíbe a pesquisa direta.Na Itália, todo tipo de pesquisa está proibida.

Para que seja formada uma opinião correta a respeito deste tema, é necessário informações concisas e certas, para que a população entenda e faça um correto julgamento; sabendo discernir o certo do errado, pois na mídia há diversas informações que podem estar distorcidas." 
Assim, nessa fase, temos dois níveis de desenvolvimento, pois é evidente que alguns alunos internalizaram as ferramentas mais rápido do que outros - embora isso não prove que eles se apropriaram delas.

Apenas para fins de citação, os problemas ortográficos continuaram ocorrendo, o que acentua a deficiência em se expressar na língua materna.

De acordo com Souza e Arroio (2007), quando escrevemos é fundamental a apropriação consciente da estrutura sonora expressa por cada palavra, e devemos dissecá-la e reproduzi-la em símbolos alfabéticos, os quais exigem estudos anteriores e memorização. Dessa forma, a prática levará ao aprimoramento da escrita e acreditamos que essa questão melhore com o decorrer do estudo.

Em relação às fontes, nenhum deles as citou, o que nos leva a crer que o texto foi escrito com base somente no que disse a pesquisadora. Isso dificulta o processo de aprendizagem e, particularmente, a aquisição da linguagem e apropriação das ferramentas.

Segundo Vygotsky, a formação da consciência, das funções psicológicas superiores, ocorre, então a partir da atividade do sujeito, com a ajuda de instrumentos socioculturais, que são os conteúdos externos, da realidade objetiva (CAVALCANTI, 2005).

Portanto, mesmo tendo feito uma pesquisa básica e utilizando a entrevista da pesquisadora, os alunos começam a aplicar vocábulos relacionados à linguagem científica e parecem lentamente dar início ao processo de internalização dos conceitos.

A estrutura ficou mais parecida com a de artigos de divulgação científica, pois os textos eram corridos, um pouco mais coerentes e curtos. Os títulos deixaram de ser didáticos e passaram a ter um valor mais chamativo, como se para atrair a atenção dos leitores.

Ficou claro para nós que os alunos encontraram muitos problemas para interpretar suas fontes e, conseqüentemente, aplicar as diversas linguagens para obter uma maior extensão em suas informações na construção da comunicação em ciência. No entanto, ficou evidente o progresso dos alunos em relação ao primeiro artigo. Meio que timidamente nota-se um pequeno domínio das ferramentas por esses alunos em relação à comunicação escrita, porém sua apropriação ainda é um fator distante. 


\subsection{Fase V}

Tendo como base o real desenvolvimento do grupo de PIC, resolvemos que seria interessante deixá-los à vontade para escolher seu próprio tema de trabalho e observar como fariam esse processo sem qualquer interferência do orientador. Nessa fase, nossa postura foi de observadores, sem fazer qualquer intervenção em seu trabalho.

Com o prazo de um mês e meio, quase dois, e com tempo disponível (ocorreu no período de férias escolares), eles tiveram de pesquisar um tema e elaborar um novo artigo de divulgação científica.

Os temas escolhidos foram a gripe suína (três alunas o escolheram), aquecimento global, alimentos transgênicos, obesidade infantil e Amazônia.

A aluna Simone redigiu dois artigos (um de gripe suína e o outro de transgenia).

"Hoje em dia, o aumento da obesidade infantil é causado por vários fatores. As principais causas da obesidade infantil são certamente, o fato de as crianças comerem excessivamente e, ou não realizarem exercício físico regular ou terem, geralmente, hábitos sedentários".

Esse trecho foi retirado do artigo sobre obesidade infantil redigido pela Soraia. Percebemos que a aluna ainda apresenta problemas quanto à expressão de argumentos e, principalmente, no modo de escrever, pois, ao lê-lo, tivemos a impressão de que se parecia com um texto didático.

"Para começar a se ter uma idéia do que sejam os alimentos transgênicos, é importante ter primeiro uma idéia do que são os chamados OGM's (organismos geneticamente modificados)”.

“A gripe suína, ao contrário do que muitos pensam, não transmitida através do consumo de carne suína e sim pelo contato com pessoas que foram infectadas pelo vírus da doença, e por vias aéreas, assim como a gripe comum”.

Os dois trechos foram retirados dos artigos escritos pela Simone. Ao compararmos esses artigos com o anterior, percebemos quase de imediato uma melhora significativa no modo de escrita do artigo. Há uma fluidez em relação à leitura do texto, tornando-o agradável de ler. Também, é possível perceber que foi ela realmente quem os escreveu, diferentemente do trecho abaixo, redigido pela colega Carla:

“Os estudos epidemiológicos e experimentais realizados têm comprovado, de maneira consistente, que a poluição do ar aumenta o risco de doenças e de mortalidade por doenças cardiovasculares, respiratórias e por câncer de pulmão ${ }^{1-2, " .}$ 
Embora o texto pareça bem redigido e apresente uma linguagem um pouco aprimorada, um detalhe no texto denota que ele não foi escrito pela aluna, e sim copiado de algum site: o uso de chamadas para explicações de rodapé (numerais sobrescritos). Havia mais uma dessas marcações no texto; no entanto, não havia as explicações. Portanto, ficou claro que essa aluna não escreveu o texto por si só; provavelmente, usou outras ferramentas, diferentes das aceitas para a elaboração de um artigo, para redigir seu artigo.

Segundo Orlandi (2000), no contexto escolar, esse tipo de ação ocorre quando o aluno repete o que o professor transmite, sem buscar o seu entendimento. Aplicando essa teoria em nosso trabalho, podemos supor que a aluna ainda não havia entendido a sistemática do trabalho e, por isso, valeu-se da cópia para elaborar seu texto.

Também acreditamos que o processo de internalização não tenha ocorrido de forma profunda nessa aluna: quando comparamos seus artigos, vimos que não houve uma melhora significativa no modo de escrever nem na forma de aplicar as ferramentas necessárias para a redação. Todos eles mantêm características similares, o que indica que não houve um domínio, e muito menos a apropriação das ferramentas, pela aluna.

Nesses casos, podemos considerar que ocorre o apagamento da real função dos textos de divulgação científica, ou seja, os alunos os tratam como aos livros didáticos, em que o importante é saber o material didático e não saber como utilizá-lo (ABREU, 2009; ORLANDI, 1996). Esse tipo de reprodução demonstra o receio do aluno em assumir seu próprio discurso, conseqüência da imagem que o aluno faz da imagem que o professor faz do próprio aluno (SANTOS, 2006).

"O contágio se dá através do contato com porcos infectados ou ambientes onde os porcos poderiam está presentes. Contudo, alguns casos humanos não envolviam este contato, mostrando a transmissão direta entre seres humanos".

O texto está bem redigido e apresenta coerência em seu conteúdo, o que denota que a aluna tenha internalizado algumas das ferramentas propostas nas reuniões.

"Muito parecida com a gripe comum, porém prima próxima de várias outras gripes que já assombraram tanto esse mundo, tais como a gripe espanhola, a gripe russa e tantas outras, a gripe suína ou no seu nome científico influenza A (H1N1) após ter seus primeiros casos no mês de março no México, virou pandemia no dia 25 de Abril de 2009".

O texto dessa aluna, a Mônica, foi bem escrito, embora fosse um texto curto, e continha informações relevantes sobre o tópico por ela escolhido. Ficou claro que ela 
estudou o tema e o transpôs para o papel de uma forma mais "jornalística”, ou seja, houve uma internalização de conceitos por ela - prova disso foi o modo como ela explicitou as informações em seu artigo: objetivas e diretas, porém com embasamento científico. A linguagem ficou evidente em sua forma de escrita, o que comprova nossa hipótese.

"Você já deve ter ouvido alguma vez, seja em revista, jornal, Internet, televisão, enfim nos vários meios de comunicação, falarem alguma coisa relacionada a Amazônia, não? Seja sobre desmatamento, pela preservação, pela diversidade de fauna e flora da região, mais e mais vem se falando na sociedade sobre a Amazônia. Mas, por quê? O que a Amazônia tem a nos oferecer?"

O aluno Pedro começa seu texto dessa forma - chamando a atenção do leitor para o que vem a seguir. O que é mais marcante é o modo como ele escreve o texto: fluido, bem estruturado e com conteúdo suficiente para que uma pessoa leiga entenda o que se passa em relação à Amazônia. Desde o começo do estudo, o aluno Pedro mostra certo domínio em relação às ferramentas, já que seus textos apresentam algumas das características procuradas por nós como, por exemplo, a linguagem científica e o modo de redação do texto.

De modo geral, nesta fase percebe-se que alguns alunos dão um "salto" enorme em relação aos outros dois artigos. A redação havia melhorado muito e a apresentação estrutural também. Embora não tivessem citado as fontes consultadas (somente um dos alunos a citou e todas com teor confiável), ficou visível que quase todos haviam pesquisado sobre o assunto, pois os textos foram redigidos com mais propriedade (exceto os que têm aparência de copiados literalmente da Internet). Também é possível visualizar uma linguagem mais científica, mais elaborada. Isso mostra que os vocábulos científicos começam a fazer parte da vida desses alunos.

Em se tratando de uma aprendizagem que seja significativa e crítica, MOREIRA (2000) estabelece algumas condições necessárias para viabilizá-la. Nesse processo, a conscientização de que a atribuição de significados é individual vincula-se ao fato de que cada aluno percebe e representa o mundo de acordo com a sua ideologia. Essa percepção por parte do aluno é importante no sentido de que o mesmo deixa de acreditar que existem respostas necessariamente certas ou erradas. Outra condição destacada pelo autor vincula-se à percepção de que a linguagem não é neutra, mas expressa e reflete o pensamento. Nesse contexto, aprender os conteúdos científicos de forma significativa 
implica em aprender a sua linguagem, o que decorre em aprender a falar e pensar de modo diferente acerca do mundo.

No entanto, para que ocorra a facilitação da aprendizagem significativa crítica, também são relevantes outros dois aspectos: que o material de aprendizagem seja "potencialmente significativo", ou seja, relacione-se com a estrutura cognitiva do aprendiz de maneira não arbitrária e substantiva (não literal) e que o aprendiz manifeste disposição em aprender, ou seja, em "relacionar de maneira substantiva e não arbitrária o novo material, potencialmente significativo, a sua estrutura cognitiva" (MOREIRA, 1995).

É exatamente o que temos aqui em nosso estudo: nossos alunos mostraram uma grande vontade em aprender, mesmo aqueles que cometeram deslizes, e pouco a pouco aprenderam a relacionar as ferramentas culturais apropriadas ao conhecimento adquirido no decorrer do estudo e, principalmente, internalizaram esse conjunto, o qual deverá ser transmitido na próxima etapa para averiguar sua consistência.

Além dos artigos, entregaram também um questionário de dez perguntas para que pudéssemos avaliar o quanto tinham se apropriado das ferramentas. As respostas revelam que a generalização dos conceitos comunicação escrita x divulgação científica é percebida por alguns deles, bem como seu processo evolutivo. Indicam também a importância da aprendizagem por meio de materiais alternativos e sua significação nesse espaço social.

O questionário proporcionou a liberdade de expressão desses alunos, que puderam discorrer sobre o que achavam de seu aprendizado e como a escrita contribuiria em suas vidas acadêmicas, o que facilita a comunicação entre aluno e professor.

Percebemos também, por suas respostas, que houve certa insegurança no início do estudo por parte deles, pois eles pouco sabiam sobre a divulgação e sobre o tema com o qual iriam trabalhar. Com o passar do tempo, isso se modificou. Mesmo aqueles que "copiaram" textos de outros locais, fizeram-no com mais propriedade e souberam escolher o que copiar. Isso mostra certo domínio dos conceitos, configurando um processo de internalização, mesmo que bem primitivo em alguns deles, e a confirmação de que a escrita é parte integrante do aprendizado em Ciências.

Contudo, quando questionados sobre o domínio das ferramentas, tivemos algumas respostas assim: 
“Na realidade não acredito ter dominado totalmente, mas aprendi muita coisa como a montagem do texto, tipo de linguagem a ser utilizada e ECT. Procurou incorporar esses requisitos lendo outros artigos de divulgação de diversos temas”.

"Acredito que sim. Em todo o processo de construção do artigo nós incorporamos essas ferramentas desde as pesquisas iniciais até a hora em que começamos a redigir o artigo”.

"Dominar... eu não dominei... mais aprendi bastante ao ponto de conseguir montar um artigo e em breve dominar essas ferramentas!"

Ficou evidente que, embora se sentissem mais seguros para redigir um artigo, não acreditavam ter dominado $100 \%$ todas as ferramentas para isso, embora soubessem as vias para chegar a esse objetivo. Além disso, nem todos entenderam a questão das ferramentas culturais, o que possivelmente atrapalhou no desenvolvimento desses alunos durante o estudo.

Na pergunta sobre como diferenciar um artigo científico de um de divulgação científica, uma aluna ainda apresentava dúvidas (sua resposta confirma isso): “... $a$ linguagem do artigo científico é bem diferente de um artigo de divulgação, nele é onde há citações do assunto, o autor visa fazer com que o tema seja mais concentrado em palavras do tipo formação do DNA e assim por diante”. Embora ela tenha feito um bom trabalho, principalmente no último artigo, é notável que ainda apresente lacunas em relação ao processo do qual participou, pois não está clara para ela a diferença entre os dois tipos de artigo.

Para a pergunta sobre o que é divulgação científica, uma delas ofereceu uma resposta que também denotava deficiência no processo de aprendizagem: "Uma divulgação de algo onde é usado termos técnicos e complexos, especialmente feita para cientistas elou profissionais da área”. Essa definição mostra que, apesar dele ter absorvido algumas ferramentas, fato mostrado em seu artigo, a estudante se confunde ao que vem a ser a divulgação científica.

Apesar desses obstáculos, os alunos reconheceram a função da escrita como sendo específica da linguagem (VYGOTSKY, 2001), com seu elevado grau de abstração, citando a necessidade da organização das idéias, da coesão e coerência do texto, da audiência, da relação com as aulas de língua portuguesa e da evolução do vocabulário, principalmente o científico.

Vygotsky (1993) aponta que o principal problema no processo de formação de um conceito é aquele que se refere aos meios pelo qual tal operação é concretizada, ou 
seja, isso significa considerar os instrumentos utilizados e a mobilização dos meios adequados e necessários para realizá-lo. A sua interpretação para o fenômeno da escrita é de que esta é uma função lingüística distinta e apresenta uma qualidade abstrata, que é o obstáculo mais importante a ser superado. A escrita exige abstração, intelectualização, está distante das necessidades imediatas, exigindo que a situação sofra um processo de recriação, de representação interna, uma ação de análise deliberada, distanciando-se desta forma das situações reais.

Talvez essas questões apontadas por Vygotsky tenham realmente se manifestado em alguns desses alunos, principalmente quando percebemos a dificuldade em transpor o conhecimento adquirido e internalizado para o papel.

Todas essas dúvidas foram explicitadas em uma reunião em uma tentativa de resolver e elucidar essas questões de modo a não terem mais dúvidas quanto ao estudo em questão. Cabe ressaltar aqui que, nessa reunião, frisamos a questão dos direitos autorais, de modo a fazer com que a aluna que utilizou o artifício "colar - copiar" pudesse analisar sua posição em relação aos textos até então entregues por ela.

\subsection{Fase VI}

Nesta fase final do estudo, o objetivo era analisar se tinham realmente se apropriado das ferramentas que lhes foi passada. Assim, o grupo deveria escolher seis alunos de sua escola e fazer com eles o mesmo processo pelo qual passaram.

A escolha dos alunos foi aleatória e apoiada pela escola e pelos pais dos alunos, que assinaram um termo de consentimento para uso de imagens ou sons, caso fossem necessários.

Para iniciar o processo, montaram um cronograma e anotaram tudo em um diário. Explicaram aos colegas o que deveriam fazer e orientaram-nos da mesma forma como o foram. Por fim, seus colegas deveriam escrever um artigo científico tendo como tema as células-tronco, uma vez que era o assunto teoricamente já dominado por eles.

Ao final de todo o processo, artigos e anotações foram entregues, bem como um relatório sobre a execução dessa fase.

a) cartilha para elaboração de artigo de divulgação científica

Os alunos do grupo de PIC elaboraram uma espécie de manual para entregar aos seus aprendizes. Nesse pequeno manual escreveram o que era é divulgação científica, o que era um artigo de divulgação científica e como era feita sua construção. Também 
incluíram alguns artigos elaborados no decorrer do estudo para que seus pupilos pudessem entender como fariam.

Verificando a apostila, pudemos constatar os mesmos problemas de sempre em relação à língua portuguesa e à citação das referências bibliográficas que, mais uma vez, foram omitidas. O que realmente nos chamou a atenção foi a inclusão dos artigos redigidos por eles, pois as cópias inseridas não eram aquelas corrigidas anteriormente. Para VYGOTSKY (1993), a palavra é o signo que serve tanto para indicar o objeto como para representá-lo como conceito, sendo nesse caso um instrumento do pensamento. Daí nossa preocupação, pois isso poderia gerar um problema "em cadeia" caso se fundamentassem totalmente nesses textos.

b) "diário de bordo"

Antes de iniciar a tarefa, os alunos criaram um caderno no qual montaram um cronograma para as atividades e anotaram todos os encontros, incluindo o que foi discutido. Essa iniciativa foi interessante porque, como a idéia foi deles, mostrou que, nesse momento do estudo, estavam realmente engajados na pesquisa e ansiosos por colocar em prática algo que aprenderam.

c) artigos dos alunos

Cinco artigos foram entregues ao final do estudo. O tema escolhido foi "célulastronco", pois era o assunto dominado por eles.

Analisando os artigos, constatamos que todos tinham uma estrutura adequada ao tipo de artigo. Um deles (“Células-tronco, crie a sua concepção”) apresentou muitos problemas de escrita, o que demonstra que houve pouca preocupação em relação à língua materna. Três deles ("Solução social ou debate ético?", "Células-tronco" $e$ "Células-tronco: a terapia curadora e a questão antiética") pareciam ter sido apenas copiados de sites de Internet - inclusive foram encontradas orações iguais em dois deles. O último deles (“Célula-tronco embrionárias: uma esperança polêmica”) era o que mais se parecia com um artigo de divulgação: sua redação era fluida e bem elaborada.

Enfim, pudemos observar que os artigos, embora iniciantes, estavam no caminho certo, uma vez que tinham estrutura adequada e informações relevantes para parecerem artigos de divulgação propriamente ditos.

d) relatório final

Um relatório final foi entregue no qual constam uma introdução, a descrição das atividades, os resultados e a conclusão. 
Em relação aos resultados, destacamos alguns trechos:

"O texto do aluno (...), esta muito bem elaborado. [...] $O$ aluno não citou fontes bibliográficas. Mas em sua totalidade é um texto muito bom”.

"O texto redigido por ela é claro no que diz respeito ao tema (...). Suas principais duvidas foram em relação a estrutura do artigo e a concordância em relação aos parágrafos iniciais".

"Lendo esse artigo dá para entender muito bem o que é células-tronco, porem ficou muito vago o principal assunto para a divulgação: religião x Ciências".

"Utilização excessiva da primeira pessoa (...). Informação incorreta: o embrião só começa a desenvolver o sistema nervoso a partir de 14 dias da fecundação (...). Sem apontar fontes de consulta (...). Acho que isso é divulgação científica: passar a informação de forma que as pessoas gostem de ciências”.

"O artigo redigido pela aluna ficou excelente, abordando vários assuntos relacionados a células-tronco (...). A aluna usou alguns termos na qual deveria ter explicado melhor, pois esses podem acabar dificultando o entendimento do leitor na hora da leitura (...)”.

“(...) percebe-se a grande quantidade de pesquisas e a falta de distinguir o certo do errado (...). Devido, não saber as fontes utilizadas pela aluna, não posso afirmar que tudo esta certo ou errado, porem acredito ter passado os conhecimentos adquiridos para a aluna”.

Analisando os trechos acima, percebemos que nossos alunos entenderam as ferramentas usadas para a elaboração dos artigos científicos. Contudo, nem todos souberam aplicá-las em seus próprios artigos, principalmente no que se refere à questão lingüística e às referências bibliográficas. Isso mostra que a internalização dos conceitos aconteceu, mas sua externalização ainda é deficiente, principalmente em relação à linguagem e à montagem do discurso, que têm como base conceitos prévios da língua materna inclusive.

Um fato positivo nessa fase foi a inovação do modo como as informações deveriam ser transmitidas. Ao elaborar a cartilha e o diário de bordo, nossos alunos tentaram mudar essa forma de externalização, oferecendo aos colegas alternativas que eles mesmos tiveram que descobrir. No entanto, acabaram por reproduzir somente o que vivenciaram, ou seja, não desenvolveram métodos diferentes daqueles presenciados para os amigos, que receberam apenas instruções. 
VYGOTSKY (1993) destaca no processo de apropriação cultural o papel mediador da linguagem. Com efeito, a linguagem tem um papel importante em relação à formação da consciência. A idéia de formação da consciência e do desenvolvimento intelectual se dá de fora para dentro, num processo de internalização, e não implicam em um entendimento de passividade do sujeito do conhecimento. Em outras palavras, alguns de nossos alunos atingiram esse nível de formação, e até dominaram as ferramentas, mas não se apropriaram delas.

Na conclusão, nossos alunos afirmaram que a divulgação científica é realmente importante para a sociedade e facilita o acesso às informações, principalmente aquelas consideradas inatingíveis para muitas pessoas da sociedade. Também citaram sua insegurança, mesmo que entrelinhas, e gratificação em aprender e transmitir algo novo. Ainda esclarecem que houve bastante dificuldade em passar seus conhecimentos para o papel, ou seja, utilizar a linguagem científica.

No geral, ficou claro que houve domínio das ferramentas culturais necessárias à criação de um artigo de divulgação por alguns deles, assim como a absorção e a aprendizagem de um conhecimento até então desconhecido para eles. Isso foi provado ao conseguirem transmitir o que aprenderam para outros e obter certo sucesso nessa empreitada (fundamentado pelos artigos entregues), expandindo ainda mais seus atributos intelectuais. No entanto, não houve a apropriação dessas ferramentas e nossos alunos não transcenderam, pois apenas reproduziram o que lhes foi passado no decorrer do estudo, além de ficar evidente que lhes faltam o aprofundamento desse conhecimento e seu aperfeiçoamento, por meio de práticas e pesquisas, para evitar os erros que foram consistentes durante todo o estudo. 


\section{CONSIDERAÇÕES FINAIS}

O uso de textos de divulgação científica em ambientes escolares vem sendo discutido nos últimos anos (ALMEIDA, 1998; MARTINS; CASSAB; ROCHA, 2001; TERRAZAN; GABANA, 2003; NASCIMENTO; SOUZA, 2007), no entanto, pesquisas baseadas em experiências reais com textos de divulgação científica são escassas (ABREU, 2009).

Com base nessa afirmação, elaboramos um estudo baseado na escrita de artigos de divulgação científica para avaliar o desenvolvimento dos alunos em relação ao domínio e a apropriação de conceitos relacionados à elaboração de artigos desse gênero.

Nossa análise mostrou características positivas quanto ao uso de métodos que viabilizaram a construção do conhecimento desses alunos. Embora o grupo tivesse poucos conhecimentos prévios sobre o que seria a divulgação científica e seu papel na sociedade, aos poucos alguns deles começaram a dominar as ferramentas necessárias à redação de artigos, aperfeiçoando timidamente sua interpretação dos textos didáticos e de artigos científicos, empregando novas formas de linguagem, especialmente aquela relacionada à área científica e intensificando o processo de aprendizagem dos temas referentes à disciplina de Ciências.

Vygotsky (2001) nos ensina que a assimilação dos conceitos científicos pressupõe um tecido conceitual já amplamente elaborado e desenvolvido por meio da atividade espontânea do pensamento ou, em outras palavras, é necessária uma base de sustentação encontrada na atividade espontânea. Essa atividade espontânea está vinculada à estrutura formada até o momento em que se iniciam os trabalhos de desenvolvimento dos conceitos científicos com o estudante e complementa ao afirmar que a assimilação do sistema de conhecimentos científicos também não é possível, senão pela relação mediada com o mundo dos objetos, por outros conceitos anteriormente elaborados.

Além disso, as opiniões expressas pelo grupo em relação ao estudo salientam a importância desse tipo de atividade, pois consideram que as tarefas desempenhadas contribuíram para o desenvolvimento de habilidades necessárias à formação acadêmica, ao aperfeiçoamento da comunicação oral e escrita e ao entendimento do processo de construção do conhecimento científico.

No entanto, é fato que, apesar de alguns deles dominarem as ferramentas necessárias à elaboração de artigos de divulgação científica, não se apropriaram delas, 
pois conseguem apenas reproduzi-las, da mesma forma que as receberam, sem, contudo, saber desenvolvê-las ou até mesmo entendê-las de modo aprofundado.

Salientamos que nosso estudo apresenta apenas um pequeno exemplo de como a linguagem escrita pode ser aplicada no ambiente escolar. Também serve para ilustrar alguns benefícios como a estreita relação entre linguagem e pensamento. Queiroz (2001, p. 146) ressalta que "o pensamento e a linguagem encontram-se imbricados - quando um deles é aprimorado, o outro quase sempre melhora. Assim, quando se solicita ao aluno que escreva algo, impinge-se a ele a tarefa de "pensar" sobre este assunto, pois o ato de escrever envolve muito mais do que simplesmente expor idéias armazenadas na cabeça. Para tanto, faz-se necessário que as idéias sejam repensadas e organizadas para finalmente serem expostas".

Considerando os esforços aplicados na resolução do problema proposto neste estudo, acreditamos que, apesar dos alunos não terem atingido a apropriação das ferramentas, a proposta teve uma boa receptividade e atingiu o objetivo de estimular o interesse pela comunicação escrita como um todo, além de proporcionar o desenvolvimento de outras habilidades, de caráter formativo, como a linguagem científica (mesmo que reduzida), o trabalho em grupo e o senso crítico. 


\section{REFERÊNCIAS BIBLIOGRÁFICAS}

ABREU, L.N.. Textos de divulgação científica no ensino superior de química: funcionamento e produção de sentidos. 2009. 207 f. Dissertação (Mestrado em Ciências - Química Analítica) - Instituto de Química de São Carlos, Universidade de São Paulo, São Carlos, 2009.

ADINOLFI, V.T.S. Ética e mídia: os periódicos de divulgação científica brasileiros e seus discursos sobre ética na ciência. 2005, 157 f. Dissertação (Mestrado em Educação) - Faculdade de Educação, Universidade Estadual de Campinas, Campinas, 2005.

ALMEIDA, M.J.P.M. O texto escrito na educação em física: enfoque na divulgação científica. In: ALMEIDA, M.J.P.M.; SILVA, H.C. (Org.). Linguagens, leituras e ensino da ciência. Campinas: Mercado de Letras, p. 53-68, 1998.

ALMEIDA, M.J.P.M.; RICON, A.E. Divulgação científica e texto literário: uma perspectiva cultural em aulas de física. Caderno Catarinense de Ensino de Física, vol. 10, n. 1, p. 7-13, 1993.

ALMEIDA, M.J.P.M.; SILVA, H.C. Condições de produção da leitura em aulas de física no ensino médio: um estudo de caso. In: ALMEIDA, M.J.P.M.; SILVA, H.C. (Org.). Linguagens, leituras e ensino da ciência. Campinas: Mercado de Letras, p. 131-162, 1998.

AMÂNCIO, A.M. Inserção e atuação de jovens estudantes no ambiente científico: interação entre ensino e pesquisa. 2004. 172 f. Tese (Doutorado em Saúde Pública) Escola Nacional de Saúde Pública Sérgio Arouca, Fundação Oswaldo Cruz, Rio de Janeiro, 2004.

ANDRÉ, M.E.D.A. Etnografia da prática escolar. 9a. Ed. Campinas: Papirus, 1995.

BAKTHIN, M. El método formal de los estúdios literários: introducción crítica a uma poética sociológica. Madrid: Alianza Editorial, 1928.

BALL, D.B.; WOOD, M.; LINDSLAY, C.; MOLLARD, P.; BUZARD, D.J.; VIVIAN, R.; MAHONEY, M.; TAFT, B.R. Research, teaching and professional development at a comprehensive university. Journal of Chemical Education, vol. 81, n. 12, p. 17961800, 2004.

BARIANI, I.C.D. Estilos cognitivos de universitários e iniciação científica. 1998. 145 f. Tese (Doutorado em Educação) - Faculdade de Educação, Universidade Estadual de Campinas, Campinas, 1998.

BRASIL. Secretária de Educação Fundamental. Parâmetros Curriculares Nacionais: Ciências Naturais. Brasília, MEC/SEF, 1997. Disponível em: <http://portal.mec.gov.br/seb/arquivos/pdf/livro04.pdf>. Acesso em 18/11/2010. 
BRASIL, Ministério da Ciência e Tecnologia. Conselho Nacional de Desenvolvimento Científico e Tecnológico. Anexo V da RN 017/2006- Bolsas por Quota no País. Iniciação Científica Júnior - ICJ - Norma Específica. 2006. Disponível em: <http://www.cnpq.br/norms/rn_06_017_anexo5.htm>. Acesso em 18/11/2010.

CABELLO, K.; MORAES, M. Educação e divulgação científica de hanseníase: histórias em quadrinhos para o ensino da doença. Associação Brasileira de Pesquisa em Educação de Ciências, Atas do V ENPEC, n. 5, 2005.

CAMPANARIO, J.M. Algunas posibilidades del artículo de investigación como recurso didáctico orientado a cuestionar ideas inadecuadas sobre la ciência. Enseñanza de las Ciencias, vol. 22. n. 3, p. 365-378, 2004.

CARNEIRO, M.H.S.; MÓL, W.L.S. Livro didático inovador e professores: uma tensão a ser vencida. Ensaio - Pesquisa em Educação e Ciências. Brasília, DF, vol. 7, n. 2, 2005.

CASA CIVIL. Disponível em: <http://www.planalto.gov.br/ccivil_03/_Ato20042006/2005/lei/L11105.htm>. Acesso em 01/12/2010.

CAVALCANTI, L.S. Cotidiano, mediação pedagógica e formação de conceitos: uma contribuição de Vygotsky ao ensino de Geografia. Caderno Cedes, Campinas, SP, vol. 25, n. 66, p. 185-207, 2005.

CHICARELLE, R.J. Formação inicial científica no curso de pedagogia. 2001. 98 f. Dissertação (Mestrado em Psicologia da Educação) - Pontifícia Universidade Católica de São Paulo, São Paulo, 2001.

COELHO, M.A.. A produção de textos escritos e suas relações com processos cognitivos. 2002. 218 f. Tese (Doutorado em Educação) - Faculdade de Educação, Universidade Estadual de Campinas, Campinas, 2002.

COLINVAUX, D. Museus de ciências e psicologia: interatividade, experimentação e contexto. História, Ciências, Saúde - Manguinhos, Rio de Janeiro, RJ, vol. 12 (suplemento), p. 79-91, 2003.

COMCIÊNCIA - $\quad$ Labjor. Disponível em: <http://www.comciencia.com.br/resenhas/gattaca.htm>. Acesso em 07/12/2009.

CSI BRASIL. Disponível em: <http://www.csibrasil.net/>. Acesso em 08/11/2010.

DINIZ, M.L. Domínio e apropriação de ferramentas culturais na aula de Ciências: o debate como ação mediada. 132 f. Dissertação (Mestrado em Ensino de Ciências). Programa de Pós-graduação Interunidades da Universidade de São Paulo, São Paulo, 2005.

EPLING, G.A.; FRANCK, R.W. Developing familiarity with the primary literature of chemistry. A student exercise. Journal of Chemical Education, vol. 56, n. 6, p. 388389, 1979. 
FERREIRA, C.A. Concepções da iniciação científica no ensino médio: uma proposta de pesquisa. Trabalho, educação e saúde, vol. 1, n. 1, p. 115-130, 2003.

FILHO, C. A divulgação científica na mídia impressa: as Ciências Biológicas em foco. Ciência \& Educação, vol. 13, n. 3, p. 351-368, 2007.

FILIPECKI, A.; BARROS, S.S.; ELIA, M.F. A visão dos pesquisadores-orientadores de um programa de vocação científica sobre a iniciação científica de estudantes de ensino médio. Ciência \& Educação, vol. 12, n. 2, p. 199-217, 2006.

FITTIPALDI, C.B. Conceitos centrais de Vygotsky: implicações pedagógicas. Revista Educação, Guarulhos, SP, vol. I, n. 2, 2006.

GAMA, L.C. Divulgação científica: leituras em classes de ensino médio. 2005, 216 f. Dissertação (Mestrado em Educação) - Faculdade de Educação, Universidade Estadual de Campinas, Campinas, 2005.

GERALDI, J.W. O texto na sala de aula. 3ª Ed. São Paulo: Ática, p. 136, 1999.

GOMES, P. Mídia, imaginário de consume e educação. Educação \& Sociedade, ano XXII, n. 74, 2001.

GRILLO, S.V.C.; OLÍMPIO, A.M. Gêneros do discurso e ensino. Filologia e lingüística portuguesa - Humanitas FFLCH/USP, São Paulo, n. 8, p. 379-390, 2006.

GRILLO, S.V.C. Gêneros primários e gêneros secundários no círculo de Bakthin: implicações para a divulgação científica. Alfa, São Paulo, vol. 52, n. 1, p. 52-79, 2008.

HENDERSON, L.; BUISING, C. A research-based molecular biology laboratory. Turning novice researchers into practicing scientists. Journal of College Science Teaching, vol. 30, n. 5, p. 322-327, 2001.

HUTCHINSON, A.; ATWOOD, D.A. Research with first and second year undergraduates: a new model for undergraduate inquiry at research universities. Journal of Chemical Education, vol. 79, n. 1, p. 125-126, 2002.

JENKINS, E.W. Practical work in science education: some questions to be answered. In: LEACH, J.; PAULSEN, A. Practical work in science education: recent research studies. Frederiksberg (Dinamarca) - Dordrecht (Holanda), Roskilde University Press Kluwer Academic Publishers, p. 19-32, 1999.

JORGE, A.S.; PUIG, N.S. Enseñanza de las Ciencias, vol. 18, n. 405, 2000.

JUNKER, B.H. A importância do trabalho em campo: introdução às ciências sociais. Rio de Janeiro: Lidador, 1971.

KAUFMAN, A.M.; RODRÍGUEZ, M.E. Escola, leitura e produção de textos. Porto Alegre: Artes Médicas, 1995. 
KNABB, M. Creating a research environment in an introductory cell physiology course. A West Chester University class molds students into "scientists-in-training". Journal of College Science Teaching, vol. 27, n. 3, p. 205-209, 1977.

LATTES, Currículo - Maria Denise Fernandes Carvalho. Disponível em: <http:// http://lattes.cnpq.br/1093806094902957>. Acesso em 01/12/2010.

LEMKE, J. Talking science. language, learning and values. Norwood, New Jersey: Ablex Publishing Corporation, 1990.

LEMKE, J. Analysing verbal data: principles, methods and problems. In: Tobin, K.; Fraser, B., International Handbook of Science Education, Dordrecht-Kluwer, 1998a.

LEMKE, J. Multiplying meaning: visual and verbal semiotics in scientific text. In: Martin, J.; Veel, R. Reading Science, Routledge, 1998b.

LEMKE, J. Research for the future of Science Education: new ways of learning, new ways of living. VII International Congress on Research in Science Teaching, Spain, 2005. Disponível em: <http:// wwwpersonal.umich.edu/ jaylemke/papers/Granada\%20Future\%20Science\%20Education.ht m>. Acesso em 10/03/2010.

LÜDKE, M.; ANDRÉ, M.E.D.A. Pesquisa em educação: abordagens qualitativas. São Paulo: Editora Pedagógica e Universidade de São Paulo, 1986.

MACHADO, A.H. Aula de Química: discurso e conhecimento. Ijuí, RS: UNIJUÍ, 1999.

MARTINS, G.M.M. Formação científica e ensino médio. 2003. 192 f. Dissertação (Mestrado em Tecnologia Educacional para as Ciências da Saúde) - Núcleo de Tecnologia Educacional para a Saúde, Universidade Federal do Rio de Janeiro, Rio de Janeiro, 2003.

MARTINS, I.; CASSAB, M.; ROCHA, M.B. Análise do processo de re-elaboração discursiva de um texto de divulgação científica para um texto didático. In: ENCONTRO NACIONAL DE PESQUISA EM EDUCAÇÃ̃ EM CIÊNCIAS, III, 2001, Atibaia. Atas... Atibaia: Associação Brasileira de Pesquisa em Educação em Ciências, 2001.

MASSI, L.. Contribuições da iniciação científica na apropriação da linguagem científica por alunos de graduação em Química. 2008. 227 f. Dissertação (Mestrado em Ciências - Química Analítica) - Instituto de Química de São Carlos, Universidade de São Paulo, São Carlos, 2008.

MOREIRA, A.P.C.; PINHEIRO, P.C.; FILHO, J.A.C. Analisando a proposta pedagógica de ensino de física do professor Pachecão. XVIII Simpósio Nacional de Ensino de Física, Vitória, ES, 2009.

NASCIMENTO, T.G. Contribuições da análise do discurso e da epistemologia de Fleck para a compreensão da divulgação científica e sua introdução em aulas de ciências. Ensaio, vol. 7, n. 2, p. 1-18, 2005. 
NASCIMENTO, T.G.; SOUZA, S.C. A produção sobre divulgação científica em eventos de ensino de ciências: vislumbrando tendências. In: ENCONTRO NACIONAL DE PESQUISA EM EDUCAÇÃO EM CIÊNCIAS, V, 2005, Bauru. Atas... Bauru: Associação Brasileira de Pesquisa em Educação em Ciências, 2005.

NATURE. Disponível em: <http://www.nature.com>. Acesso em 01/12/2010.

NEVES, R.M.C. Lições da iniciação científica ou a pedagogia do laboratório. História, ciências e saúde, vol. 8, n. 1, p. 71, 2001.

OLIVEIRA, C.M.; CARVALHO, A.M.P. Escrevendo em aulas de ciências. Enseñanza de Las Ciencias, número extra, 2005.

ORLANDI, E.P. A linguagem e seu funcionamento: as formas do discurso. Campinas: Pontes, 1996.

ORLANDI, E.P. Discurso e leitura. São Paulo: Cortez, 2000.

ORLANDI, E.P. Discurso e texto: formulação e circulação de sentidos. Campinas: Pontes, 2001.

PACCA, J.L.A.; VILLANI, A. Categorias de análise nas pesquisas sobre conceitos alternativos. Revista de Ensino de Física, vol. 12, p. 123-138, 1990.

PARÂMETROS CURRICULARES NACIONAIS: introdução aos parâmetros curriculares nacionais - Secretaria de Educação Fundamental. Brasília: MEC/SEF, p. 22, 1997.

PATTERSON, E.W. Structuring the composition process in scientific writing. International Journal of Science Education, vol. 23, p. 1-16, 2001.

PEREIRA, R. Infância, televisão e publicidade: uma metodologia de pesquisa em construção. Cadernos de Pesquisa, n. 115, p. 235-264, 2002.

QUEIROZ, S.L. A linguagem escrita nos cursos de graduação em química. Química Nova, vol. 24, n. 1, p. 143-146, 2001.

QUEIROZ, S.L.; ALMEIDA, M.J.P.M. Do fazer ao compreender ciências: reflexões sobre o aprendizado de alunos de iniciação científica em química. Ciência \& Educação, vol. 10, n. 1, p. 41-53, 2004.

REGO, T.C. Vygotsky: uma perspectiva histórico-cultural da educação. Petrópolis, RJ: Editora Vozes, 1995

REVISTA

FAPESP.

Disponível

em: <http://www.agencia.fapesp.br/materia/9490/noticias/usp-lanca-programa-de-preiniciacao-cientifica.htm>. Acesso em 10/10/2010. 
RIVARD, L.P.; STRAW, S.B. The effect of talk and writing on learning science, an exploratory study. Science Education, n. 84(5), p. 566-593, 2000.

SÁ, L.P.; QUEIROZ, S.L. Promovendo a argumentação no ensino superior de Química. Química Nova, vol. 30, n. 8, p. 2035-2042, 2007.

SALZANO, J. Análise de um livro didático em língua portuguesa. Integração. São Paulo, SP, n. 42, p. 285-293, 2004.

SANTOS, G.R.. O artigo científico no ensino superior de química: desenvolvendo habilidades de leitura e interpretação. 2006. 132 f. Dissertação (Mestrado em Ciências - Química Analítica) - Instituto de Química de São Carlos, Universidade de São Paulo, São Carlos, 2006.

SANTOS, G.R.; QUEIROZ, S.L. O papel da leitura e discussão de artigos científicos no favorecimento da compreensão dos alunos sobre a natureza da ciência: um estudo preliminar. In: ENCONTRO NACIONAL DE PESQUISA EM EDUCAÇÃO EM CIÊNCIAS V, 2005, Bauru. Anais... Bauru: Associação Brasileira de Pesquisa em Educação em Ciências, 2005.

SILVA, H.C. Discursos escolares sobre gravitação newtoniana: textos e imagens na física do ensino médio. 2002, 233 f. Tese (Doutorado em Educação) - Faculdade de Educação, Universidade Estadual de Campinas, Campinas, 2002.

SILVA, H. et al. Cautela ao usar imagens em aulas de ciências. Ciência e Educação, vol. 12, n. 2, p. 219-233, 2006.

SOUZA, D.D.D.. Sobre a mediação de um material instrucional na aprendizagem de estudantes em aulas de química - gêneros do discurso e argumento. 2010. $140 \mathrm{f}$. Dissertação (Mestrado em Educação - Ensino de Ciências e Matemática) - Faculdade de Educação, Universidade de São Paulo, São Paulo, 2010.

SOUZA, D.D.D.; ARROIO, A. Produção de textos de comunicação em ciências nas aulas de química em uma escola de ensino médio. VI ENPEC - Encontro Nacional de Pesquisas em Educação em Ciências, Florianópolis, SC, 2007.

TAKEUCHI, C. A.; TANNURI, U. A polêmica da utilização de células-tronco embrionárias com fins terapêuticos. Revista da Associação Médica Brasileira [online], vol. 52, n. 2, p. 63, 2006.

TERRAZZAN, E.A.; GABANA, M. Um estudo sobre o uso de atividade didática com texto de divulgação científica em aulas de física. In: ENCONTRO NACIONAL DE PESQUISA EM EDUCAÇÃO EM CIÊNCIAS, IV, 2003, Bauru. Atas... Bauru: Associação Brasileira de Pesquisa em Educação em Ciências, 2003.

TILSTRA, L. Using journal articles to teach writing skills for laboratory reports in general chemistry. Journal of Chemical Education, vol. 78, n. 6, p. 762-764, 2001. 
VILLANI, C.E.P.; NASCIMENTO, S.S. A argumentação e o ensino de Ciências: uma atividade experimental no laboratório didático de física do ensino médio. Investigações em Ensino de Ciências, vol. 8, n. 3, p. 187-209, 2003.

VERGNAUD, G. Piaget e Vygotsky: convergências e controvérsias. Revista Geempa, Porto Alegre, RS, n. 2, p. 76-83, 1993.

VYGOTSKY, L.S. Pensamento e linguagem. São Paulo: Martins Fontes, 1987.

VYGOTSKY, L.S. A formação social da mente: o desenvolvimento dos processos psicológicos superiores. Org. Michael Cole et al., 6ª Ed., São Paulo: Martins Fontes, 1998.

VYGOTSKY, L.S. A construção do pensamento e da linguagem. São Paulo: Martins Fontes, 2001.

WELLS, G. Indagación dialógica. Espanha: Paidós, 2001.

WERTSCH, J.V. Voices of the mind: a sociocultural approach to mediated action, 4a. Ed., Cambridge: Harvard University Press, 1997.

WERTSCH, J.V. Mediated action. In: Bechtel, W.; Graham, G. A companion to cognitive science. Oxford, Blackwell, p. 518-525, 1999.

WHELAN, R.J.; ZARE, R.N. Teaching effective communication in a writing-intensive analytical chemistry course. Journal of Chemical Education, vol. 80, n. 8, p. 904-906, 2003.

WITTER, G.P. Possíveis interações entre ciência e educação. Jornal da Iniciação Científica, vol. 2, n. 3, p. 7, 2000. 
ANEXOS 


\section{ANEXO I}

\section{Perfil dos alunos do grupo de PIC}

1. Nome:

2. Idade:

3. Série:

4. Bairro em que moram:

5. Tem acesso à Internet?

6. Tem computador em casa?

7. Você trabalha?

8. Como são seus hábitos de leitura?

9. Quantas horas de dedica ao estudo por semana? 


\section{ANEXO II}

\section{Questionário aplicado ao grupo de PIC na Faculdade de Educação da USP}

1. O que é divulgação científica?

2. Qual a finalidade da divulgação científica?

3. Quem faz divulgação?

4. Quais são suas fontes de informações sobre Ciências?

5. É possível aprender Ciências em revistas? Televisão? Jornal? Cinema? Rádio?

6. Por que você assiste à televisão?

7. Qual a finalidade?

8. Quando você vai ao cinema, qual a finalidade?

9. É possível aprender Ciências no cinema? [filme]

10. Quando você assiste a um filme em que aparece algo sobre Ciências, você acredita nessa informação? É correta ou errada?

11. Você conhece algum filme que fala sobre Ciências? Qual filme? O que falava sobre Ciências nesse filme? 


\section{$\mathbf{1}^{\mathrm{a}}$ fase de dados}

$\underline{\text { (realizada de novembro de } 2008 \text { a fevereiro de 2009) }}$

Questionário aplicado em 56 salas (Ensino Fundamental II e Ensino Médio) da Escola Estadual Professora Hadla Feres

$\underline{\text { Pesquisa - Tema: Ciências }}$

\begin{tabular}{|c|}
\hline Sexo: F( ) M( ) \\
\hline Grau de escolaridade: \\
\hline Trabalha: SIM ( ) $\quad$ Não ( ) $\quad$ Período: \\
\hline Tem acesso à Internet? SIM ( ) NÃO ( ) Quantas horas acessa? \\
\hline O que costuma acessar? \\
\hline Tem televisão? SIM ( ) NÃO ( ) Quantas horas assiste? \\
\hline O que costuma assistir? \\
\hline Costuma ler? \\
\hline O que costuma ler? \\
\hline Freqüenta a biblioteca? SIM ( ) NÃO ( ) \\
\hline Por quê? \\
\hline Freqüenta o cinema? SIM ( ) NÃO ( ) \\
\hline Por quê: \\
\hline Religião: \\
\hline Tem irmãos? SIM ( ) \\
\hline Costuma conversar sobre Ciências com seus pais? SIM ( ) \\
\hline O que costuma conversar? \\
\hline Gosta das aulas de ciências? SIM ( ) \\
\hline Gosta do(a) professor(a)? Por quê? \\
\hline
\end{tabular}




\section{$\underline{\text { Gerais }}$}

1. O que vem em sua cabeça quando escuta a palavra "ciências"?

2. Que meio utiliza para obter conhecimento e informações sobre ciências?

3. Para você o que é ciências?

4. Você se interessa pelo tema "ciências"?

5. Qual a importância dos conhecimentos científicos?

6. Tem diferença entre as ciências aprendidas na escola e fora da escola?

7. As ciências interferem diretamente ou indiretamente na sua vida? De que maneira?

8. Onde você mais ouve falar sobre ciências? Você acha suficiente?

9. Quem faz ciências?

10. Você acha que as pessoas na sociedade sabem o que é ciências?

11. É importante que elas saibam?

12. As ciências na televisão é a mesma da escola? Por quê?

13. Você acha que a sua opinião a cerca de alguns assuntos relacionados às ciências é influenciado pelo que sua religião impõe? De que forma?

14. Você escolheria alguma profissão ligada às ciências? Qual?

15. O que vem em sua cabeça quando escuta a palavra cientista?

16. O que faz um cientista?

\section{Específicas}

1. Na sua opinião, qual é a origem da vida?

2. O que você entende por DNA?

3. O que são células-tronco? Onde podemos encontrar?

4. Você sabe por que certos grupos ligados às ciências, religião e política são contra o uso de células-tronco embrionárias? Por quê?

5. O que é aquecimento global?

6. O que são mudanças climáticas?

7. O aquecimento global e mudanças climáticas são a mesma coisa?

8. A ciência que você vê nos filmes é correta? Como você chega a essa conclusão?

9. Já adquiriu algum conhecimento de ciências em filmes? Dê um exemplo.

10. Que tipo de problema as ciências causam em nossas vidas?

11. A ciência possui um limite? Pode resolver qualquer problema?

12. Ciências e religião podem andar juntas?

13. O que você aprendeu sobre ciências na escola que já usou no seu dia-a-dia? 
14. Existe diferença entre alimentos transgênicos e alimentos geneticamente modificados?

15. Você já consumiu alimentos transgênicos? É a favor ou contra? Por quê?

16. Você é a favor ou contra o petróleo e o biocombustível? Por quê?

17. Você gostaria de saber mais sobre ciências? Por quê?

\section{Alguns dados considerados relevantes sobre os alunos para fins de consulta:}

Total de participantes: 112

Idade: 10 a 18 anos

Sexo: 64 meninas e 48 meninos

Grau de escolaridade: do $6^{\circ}$ ano do Ensino Fundamental II ao $3^{\circ}$ ano do Ensino Médio 


\section{ANEXO IV}

$2^{a}$ fase de dados

\section{Questionário sobre o filme "Gattaca - Experiência Genética" com respostas dos alunos envolvidos no projeto (fevereiro de 2009)}

\section{(O questionário foi aplicado após a exibição do filme e aqui reproduzido de forma integral.)}

1. O que mais chamou sua atenção na história?

"A forma como o personagem, que não me recordo conseguiu se passar pelo outro".

"O que mais me chamou a atenção foi aquela "mudança de identidade", o uso do sangue do outro, mudança de aparência etc.”

"Apesar de saber que se trata de algo ainda muito distante da realidade, o que mais me chamou a atenção foi o fato de pelo DNA poder descobrir se a pessoa tinha probabilidade a diversas doenças etc.”.

"O fato das crianças já nascerem com o seu destino traçado. A mutação genética que há nas crianças que nascem "perfeitas", sem a probabilidade de nada ruim".

"O fato que pelo DNA, conseguia ver todas as características da pessoa, inclusive coisas como, as probabilidades para doenças, capacidade intelectual, e que, por isso mesmo, a pessoa era escolhida para trabalhar de acordo com o que o DNA dizia de você".

"O fato de se fazer passar por outra pessoa através do DNA, usando o DNA de outra pessoa por causa da discriminação de pessoas consideradas "incapazes"”.

2. Você acha que é possível entender o que é DNA apenas assistindo ao filme? Por quê?

“Talvez não, pois apesar de demonstrar como seria, ou melhor como é, é algo vago que não mostra realmente como é o DNA”.

"Não, com o filme se pode ter uma noção sobre o que é mas não muita coisa. Pois no filme mostra um certo avanço tecnológico que não é a nossa realidade de hoje, mais sim do futuro”.

"O básico eu acredito que sim, porque no filme apesar de mostrar do que o DNA é capaz, mostra algumas coisas que ainda não são reais”.

"Um pouco, pois no filme fica bem claro que o DNA é único/intransferível e que guarda todas suas informações genéticas, porém é somente isso que ele mostra”. 
"Dá para se ter uma pequena noção, como entender que o DNA é o material genético da pessoa, que possui todas suas características, além do mais é algo único. Porque é um filme fictício e nem tudo o que foi apresentado é verídico”.

“Entender tudo não. Há coisas no filme que são duvidosas, porém dá pra entender que o DNA é único de pessoa para pessoa e que ele contem informações importantes para elas (informações que nem sempre são 100\%)".

3. Qual material você pesquisaria para saber mais sobre o código genético?

"Artigos, pesquisas, trabalhos realizados antes e atuais para saber o que ele realmente é”.

"Usaria a internet, um livro na qual falasse sobre genética, pediria ajuda e informações aos professores do ramo e usaria revistas sobre o assunto”.

“A Internet, livros, revistas, professores".

"Livros, internet e revistas relacionadas ao assunto. Como no exemplo de uma revista que vem dentro do jornal o Estado de São Paulo, que traz informações/curiosidades e uma delas foi o DNA".

"Livros didáticos de ciências, internet e pesquisas feitas por cientistas".

"Livros sobre DNA, alguns documentários e filmes e professores e pessoas que entendem do assunto".

4. Com base em seus conhecimentos sobre DNA, de que forma você acha que a fertilização artificial contribuiria para a humanidade? Justifique sua resposta.

"Contribuiria de uma forma vantajosa, para as mulheres que não têm filhos, a prevenção de doenças, etc.”.

"Na minha opinião de uma certa forma seria bom, pois eles poderiam manipular os "fetos” para que não houvessem doenças".

"Talvez sim. A pessoa seria quase perfeita geneticamente, porém por mais que tudo isso acontecesse ainda assim faltaria alguma coisa. No filme, os pais têm o poder de escolher as características de seu filho, porém por mais perfeito que fosse ainda faltaria algo".

"Dependo em qual situação a humanidade se encontra no momento, pois nessa fertilização pode escolher o sexo da criança e se tivesse mais mulheres que homens, poderia altera e só nascer homens. Vice-versa (outros casos também)”. 
“Teria seus pontos positivos como evitar possíveis doenças que a pessoa poderia ter, mas há coisas como escolher as características de uma pessoa como escolher a cor dos olhos, que não tem a mínima necessidade. Mas, no caso de evitar doenças ajudaria muito".

"Só ajudar casais a terem filhos. Nem todos métodos artificiais por mais que tecnológicos, etc. são melhores que os naturais”.

5. Você acha que a manipulação genética é eficiente?

"Sim, desde que seja usada para o bem".

"Sim, pois ela pode ajudar em relação a doenças. E também acho que não pois essa manipulação pode modificar os sentimentos, as emoções das pessoas”.

"Talvez sim."

"No caso do filme não, pois as pessoas perdem as emoções e os sentimentos. São secas e não se divertem. Não também pois pode haver erros".

"Nem sempre, pois está sujeito a erros, como é característica própria do ser humano".

"Pode ser que sim e pode ser que não. Da mesma forma que pode ser eficiente está sujeita a acontecerem erros. Por ser uma coisa manipulada, podem acontecer mais erros que do modo natural, no qual acontecem anomalias, porém rara. Manipulação genética é feita pelo ser humano que pode fazer um erro de cálculo, cometer uma distração e etc. E como pode ser usada para o bem pode ser usada para o mal”.

6. Depois de assistir o filme, você acha que uma sociedade baseada na manipulação genética é mais viável?

"Não, pois muitas pessoas viviam-se incapazes de realizar certas atividades".

"Não, a sociedade é mais seca, não demonstram sentimento algum, elas acabam se tornando pessoas muito parecidas em relação ao modo de ser e agir”.

"Não. Acredito que tentar criar seres humanos perfeitos não daria certo, até porque acredito que seja quase impossível”.

"Não, pois apesar de ter uma probabilidade menor a violência, depressão etc., estas pessoas (perfeitas) não tem sentimentos e emoções".

"Não, porque embora formem pessoas com um "potencial melhor" e qualidade de vida melhor, com poucas probabilidades de doença não haveria lugar para o "sentimento"”, 
"Não. Pois limitaria os seres humanos que são capazes sim de superarem seus próprios limites e o governo e etc "fariam" as pessoas segundo o que é bom para eles".

7. É possível uma pessoa trocar de DNA com uma outra? Justifique.

"Não, o que é possível é que as informações, que contenham no DNA possam ser copiados, e não trocados, pois cada pessoa têm um DNA diferente”.

"Não, pois o DNA é como um código de cada um, não tem como trocar, é como códigos de barra "cada um tem o seu"”.

“Não. O DNA é uma característica própria de cada pessoa é impossível mudar”.

"Não, o DNA é único e intransferível, cada um tem o seu e ponto final”.

"Em minha opinião não, pois o DNA é algo que só você possui, não há outro igual”.

"Não. O DNA é único de cada um. Ele é feito no nosso corpo, com o nosso corpo. Só o João faz o DNA do João".

8. Que fontes você acha que foram usadas para o tema em questão?

"Fontes sobre a reduplicação do DNA, clonagem etc.".

"Muitas pesquisas sobre genética e tecnologia”.

"Acredito que com base em algumas pesquisas, cientistas, revistas, Internet entre outros".

"Pesquisa em livros, internet e revista e muita imaginação, pois acaba demonstrando um futuro em que esta distante de nós, coisas que estão muito longe para acontecer”.

"Estudos baseados em experiências feitas. Como, por exemplo, a fertilização artificial e os estudos e pesquisas feitos sobre DNA”.

"Documentários, professores e pessoas que estudaram sobre o tema, artigos e livros".

9. Em sua opinião, qualquer tema científico pode ser abordado em um filme?

"Sim, desde que seja bem explicado e não seja ficção”.

"Sim, basta ter um bom material em mãos, saber sobre o tema abordado e usar e abusar da criatividade”.

"Acredito que quase todos".

"Dependendo do autor, pois para abordar um tema científico tem que ter muita capacidade e ofilme deve demonstrar um pouco de concordância (no mínimo)".

"Sim, porque nem sempre o que vemos em um filme é real e verdadeiro, podendo ser acrescentado algo que foge da realidade. E, nem, sempre o que é abordado é correto”. 
"Sim, depende a forma que o tema e abordado de forma as pessoas se interessarem, entenderem e não "florear" muito e fazer elas quererem pesquisar".

10. Em sua opinião, o filme é uma forma de divulgação científica ou apenas um instrumento de entretenimento? Ajudaria em uma aula de Biologia? Justifique.

"É uma forma de divulgação científica, concerteza ajudaria, por que além de acrescentar conhecimento, pode até mesmo despertar o interesse dos alunos para o determinado tema".

"É uma forma de divulgação, pois ele transmite muitas informações importantes. Ajudaria um pouco, pelo menos assistindo ao filme se pode ter uma boa base sobre Genética, e isso é bom".

"O filme pode sim ser uma forma de divulgação científica, até porque a partir do filme pode-se despertar na pessoa o interesse pelo assunto abordado. Acredito que ajudaria em aulas de Biologia, mostra mais o básico, mas dá para se ter uma noção”.

"Os dois, um pouco, pois apesar de mostrar um pouco de DNA (o básico) no plano de fundo da história há um enredo que envolve amor, superação..."

"Ele é ao mesmo tempo uma forma de divulgação cientifica por falar do DNA e oferece entretenimento por causa da história de amor e superação. Ajudaria a ter uma noção do que é o DNA e o que ele representa, como ter nossas características nele”.

"Pode ser uma divulgação científica. Ajudaria em aulas de biologia pois os fatos desse filme são baseados em informações pesquisadas para deixar o filme o mais real possível. Mas tem que tomar cuidado com os fatos se são verídicos ou não”. 


\title{
ANEXO V
}

$3^{\text {a }}$ fase de dados

Redação de um artigo de divulgação científica tendo como base o tópico "DNA" (março e abril de 2009)

(Os artigos foram reproduzidos de forma integral e os nomes dos alunos foram trocados para preservar sua identidade.)

\begin{abstract}
ARTIGO 1

\section{Manipulação genética: a ética da igreja}

por Pedro

O Papa João Paulo II pediu ontem o reconhecimento jurídico do embrião humano, em 'particular seu direito fundamental à vida', durante o ângelus na Praça São Pedro. Ele lembrou que todo ser humano deve 'ter garantido seu direito de se desenvolver segundo seu próprio potencial e assegurada a inviolabilidade da concepção até a morte natural'. - Ninguém, destacou o Papa, é dono da vida, ninguém tem direito de manipular, oprimir ou tirar a vida, seja a do próximo ou a sua própria, e ainda menos fazê-lo em nome de Deus - acrescentou. O novo chamado do Papa em favor da vida condena o aborto, a eutanásia, a manipulação genética, a fecundação artificial e 'quem mata em nome de Deus'.
\end{abstract}

Retirado de:

http://comrainhadapaz.br.tripod.com/comunidaderainhadapaz/id11.html no dia 21/04/2009 às $12 h 37$

É de conhecimento público a posição da Igreja Católica com relação a todo e qualquer tipo de manipulação genética, de fato, a Igreja Católica se mostra contra, e isso gera uma enorme polêmica dentre a população. Tanto para a Igreja Católica quanto para a Ciência a manipulação genética é um assunto que deve ser bem discutido. Deve-se analisar os vários os ponto-de-vistas de cada um no âmbito de se chegar a uma conclusão concreta antes de dizer preconceituosamente "que a Igreja quer controlar à tudo e à todos" ou "a ciência é ateia". Mas, você já se perguntou quais são os argumento que a Igreja apresenta por ser contra a manipulação genética? Esses argumentos são satisfatórios? Por que muitos cientistas discordam de tais argumentos? Este artigo responderá à algumas dessas perguntas.

\section{A posição da Igreja}


Segundo a doutrina da Igreja Católica, (e de outras igrejas também) Deus é o criador de tudo e de todos e somente ele pode dar, "modificar" (processo evolutivo natural) ou tirar a vida, "A ninguém é lícito destruir diretamente um ser humano inocente, sendo isso gravemente contrário à dignidade da pessoa e à santidade do Criador" (Compêndio do Catecismo da Igreja Católica, nº66 da página 144).

\section{O embrião, ser humano?}

Para a Igreja manipular um ser em sua formação, um embrião, modificando sua estrutura e negando a esse ser o direito de se desenvolver livremente é algo imoral, pois ninguém tem direito sobre a vida de ninguém. É claro que o embrião não é algo intocável, a Igreja concorda que se façam experiências científicas com seres humanos quando essas experiências não lhes comportem riscos desproporcionados, ou quando visa a saúde ou melhorias das condições de saúde e sobrevivência desse ser. Sempre respeitando sua vida e seu direito de desenvolver-se, de forma a não causar sua morte ou "usá-lo" para os mais variados fins como de clonagem e inseminação artificial, que são formas de se "criar" seres humanos com características pré-determinadas, o que vai contra os princípios não só da Igreja Católica mas também vai contra todos os princípios éticos cristãos, e da maioria ou até mesmo de todas as religiões.

\section{A visão dos cientistas}

Para muitos cientistas, o embrião só é considerado ser humano depois de 14 dias de sua concepção, antes desse período ele é chamado de pré-embrião. Uma grande fonte células-tronco totipotentes (ou embrionárias), que são aquelas que podem se desenvolver em qualquer tecido do nosso corpo, diferente das células-tronco adultas encontradas em várias partes corpo, que tem menor capacidade de originar outros tecidos, pois as célula-tronco adultas já tem uma "programação" para se desenvolverem em tecidos específicos conforme onde são encontradas. Acredita-se que as células-troco poderão ajudar no desenvolvimento da cura de doenças como Leucemia, Mal de Alzheimer, Mal de Parkinson e até diabete, dentre muitas outras doenças généticas.

\section{A polêmica}

Porém, quando se faz uso de células-troco embrionárias para pesquisas e etc se acaba tendo que descartar o embrião. Aí é que está a polêmica, pois diversos setores da sociedade, principlamente os religiosos fazem fortes objeções às experiências com células-tronco embrionárias pois consideram o embrião como ser humano, desde o momento de sua concepção, ou seja, desde o momento em que o espermatozóide fecunda o óvulo formando um embrião em fase unicelular, um ser humano no início de 
seu desenvolvimento.

\section{Por que condenar a inseminação artificial?}

O problema surge também, segundo Dom João Bosco Oliver de Faria, Bispo de Patos de Minas, em Engenharia Genética e sociedade, quando as experiências deixam de visar o bem de um embrião para atender ao comodismo e bem-estar dos pais, que querem um filho perfeito segundo seus critérios e não um filho com suas características próprias, decididas pelas seleção natural dos genes do pai e da mãe. Agindo assim, os pais tiram a liberdade do filho de ter um "eu" próprio, para ter um "eu" já determinado por seu pais.

Os cientistas afirmam que a inseminação artificial, é para ajudar casais que não conseguem por meios naturais a terem filhos. Tal prática não é aceita pela Igreja pois não segue os meios naturais que representam a construção da família através dos laços do matrimônio que é consagrado por Deus. Daí muitos contestam afirmando o direito que casais têm de contituir uma família, porém a Igreja não vê um filho como direito mas, como dom de Deus, dom esse que nem sempre é dado aos casais. "O que se condena não é o uso da técnica, mas a separação e um dualismo entre a dimensão biológica fecundativa e a dimensão espiritual do 'EU' esponsal”, diz Dom João Bosco Oliver de Faria, Bispo de Patos de Minas em Engenharia Genética e sociedade. É válido também quando os métodos usados pelos cientistas visam ajudar o casal no ato conjugal, pois a presença do ato conjugal como condição para a procriação digna da pessoa humana se faz necessária para o contexto propriamente matrimonial, mas sempre respeitando o direito a vida e o direito de se desenvolver do embrião.

\section{Clonagem reprodutiva ou terapêutica, qual delas é moral?}

Para cada grupo na sociedade, as respostas à essa pergunta irão variar muito. Porém, a Igreja se mantem firme na sua posição contra todo e qualquer ato que venha a modificar a genética de um ser humano(um embrião), ou desperdiçá-lo.

“A obtenção de embriões humanos por clonagem, tanto com fins de reprodução como de terapia e investigação, implicaría na destruição de grande parte deles. Por exemplo, para a ovelha 'Dolly', foi necessário 'desperdiçar' centenas de embriões. Mais ainda, o elevado risco de transmissão de doenças ou malformações que implicaria essa técnica nos leva à novas razões para sua proibição ética. Isto vale especialmente pelo que se entende de clonagem 'terapêutica"', diz o Cardeal Alfonso López Trujillo, presidente do Conselho Pontificio para a Família.

Já o sanitarista e bioeticista Fermin Roland Schramm, em seu artigo A Moralidade da 
Clonagem (julho de 2002), alega que seja a clonagem reprodutiva lícita ou não, estará extremamente ligada ao aumento da infertilidade, "Deste ponto de vista pode ser considerada um bem pois evita sofrimentos evitáveis. Este tipo de clonagem pode, por exemplo, ajudar casais que queiram ter um filho sem recorrer à reprodução assistida através de um doador externo (chamada heteróloga) ou que queiram selecionar o sexo de sua cria para evitar doenças genéticas ligadas ao sexo." diz ele. Fermin Roland Schramm acredita também que não há nenhum problema moral com a clonagem terapêutica, já que visa a terapia contra doenças de origem genética. “ Portanto, a clonagem terapêutica é moralmente legítima porque permite o desenvolvimento de terapias úteis a um grande número de pessoas, evitando seu sofrimento e melhorando em princípio sua qualidade de vida" alega ele.

Surge então, a discussão de salvar vidas destruindo ou manipulando outras (os embriões). Como já foi dito antes para a Igreja, somente Deus pode dar, "modificar" ou tirar a vida. Entramos também numa já discutido neste artigo: a inseminação artificiale manipulação de embriões, sendo eles considerados seres humanos ou não.

\section{Uma polêmica entre os cientistas}

Entre os muitos cientistas e bioeticistas, se encontra uma grande polêmica quando é discutido que a manipulação genética pode gerar a problemática de muitos a usarem para melhorar a linhagem, ou seja, criar seres humanos perfeitos, saudáveis física e até mesmo psicologicamente, o que geraria um preconceito maior que todos os preconceitos já vistos. Maior que o preconceito por etnia, sexo, idade, orientação sexual e até por classes sociais: o preconceito pelo DNA, que não discriminaria negros e brancos, homens e mulheres, jovens ou idosos, homossexuais e heterossexuais, ricos e pobres, mas sim, discriminaria as pessoas, pela sua genética.

Quando se fala em discriminar as pessoas por sua genética, se quer, por exemplo, dizer que as pessoas com à alguma doença seriam inferiores ou menos capazes que as mais saudáveis. De certa forma, tal discussão é exemplificada no filme Gattaca - Experiência Genética, direção de Andrew Niccol, 1997.

\section{Conclusão}

Este artigo de divulgação cientifíca não visa dizer quem está certo, se a Igreja (de um modo geral todas a religiões), ou a Ciência. Mas propõe ao leitor que analise os conceitos de ambos e crie sua própria posição.

Tanto a Igreja, quanto a Ciência, possuem uma posição diferente sobre manipulação 
genética e outros vários assuntos, muitas vezes, tal posição é precipitada por parte da população, e acaba discriminando uma da outra logo aos primeiros acontecimentos mais polêmicos dentre a sociedade que envolvem a ética da Ciência e a ética da Igreja.

Por isso, este artigo explica de forma bem resumida, a visão da Igreja Católica, principal opositora da Ciência no assunto de manipulação genética, e que por isso é, de fato, a mais atacada por diversos órgãos (que não necessariamente a Ciência).

Deve se escarecer que ela se põe contra à assuntos que considera ser contra sua doutrina, mas que tem um fundamento que deve ser, junto com os fundamentos cientificos, analisado e contraposto para que de acordo com as próprias conclusões, ao tomar uma posição, que seja uma posição fundamentada, que tenha analisado os dois lados e chegado a uma conclusão concreta, segundo o que cada um acredita.

\section{Referências:}

Academia Pontificia para la Vida. Notas históricas. Retirado de: http://www.aciprensa.com/clonacion/documento.htm em 21/04/2009 às 10h58;

Cardeal Alfonso López Trujillo, Presidente do Conselho Pontifício para a Família. Objeciones técnicas, éticas y antropológicas a la clonación humana. Retirado de: http://www.aciprensa.com/clonacion/lopez-trujillo2.htm em 21/04/2009 às 10h30;

Compêndio do Catecismo da Igreja Católica, Conferência Nacional dos Bispos do Brasil. n466 da página 144. 2005;

Faria, João Bosco Oliver de, Bispo de Patos de Minas. ENGENHARIA GENÉTICA E SOCIEDADE. Retirado de: http://www.ghente.org/temas/clonagem/engenharia.htm em 21/04/2009 às 09h38;

Kessler,

Cynara

C.;DNA

e

RNA.

Retirado de:

http://www.algosobre.com.br/biologia/dna-e-rna.htmlem 17/04/2009 às 02:10;

Machado, Maria Cristina. Sobral, Paula Roque. Barbosa, Maria Cristina. MANIPULAÇÃO GENÉTICA, NORMA JURÍDICAS OU ÉTICAS?. SOCIOLOGIA - PROBLEMAS E PRÁTICAS Nº101991,PP.115-126;

Notícia: Papa condena manipulação genética e fecundação artificial (16:30 _ $\underline{04 / 02 / 2002) .}$ Retirado de:

http://comrainhadapaz.br.tripod.com/comunidaderainhadapaz/id11.html em 21/04/2009 às $12 \mathrm{~h} 37$;

Paiva, Lília Rodrigues. Células-tronco. Benefícios do avanço da ciência genética. $\underline{\text { Retirado de: http://www.racionalismo-cristao.org.br/gazeta/razao/celulas-tronco.html }}$ 
em 12/06/2009 às 11 h57;

Schramm, Fermin Roland. PhD. Bioeticista, Pesquisador Associado da Escola Nacional de Saúde Pública da Fundação Oswaldo Cruz, ENSP/FIOCRUZ, e Consultor em bioética do Instituto Nacional do Câncer, INCA.; A MORALIDADE DA CLONAGEM, Artigo publicado no jornal arte \& política, ano V, número XV, de 26 de julho de 2002, pp. 4-5., retirado de: http://www.ghente.org/temas/clonagem/moralidade.htm em 21/04/2009 às 11h09;

Senador Leomar Quintanjlha. Parecer do projeto de lei do senado $\mathrm{n}^{\circ}$ 285, de 1999. Retirado de: http://www.ghente.org/doc_juridicos/parecer285.htm em 21/04/2009 às $10 \mathrm{~h} 36$.

\section{Nota:}

Carta Encíclica Evangelium vitae, do Papa João Paulo II, sobre o Valor e a Inviolabilidade

da Vida Humana 25 de março de 1995. 


\section{ARTIGO 2}

\section{$\underline{\text { Artigo ciêntifico sobre ácido desoxirribonucléico - DNA }}$}

Ácido desoxirribonucléico - DNA

por Andressa

O Ácido Desoxirribonucléico ou DNA tem esse nome esse nome porque o açúcar que o forma é a desoxirribose.

Para se ter uma idéia ou uma imagem do DNA, basta pensar em duas fitas paralelas em forma de serpentina, ou helicoidais (de dupla hélice). Essas fitas são formadas de filamentos, já que as moléculas do DNA têm a forma filamentosa. São filamentos paralelos devido à ponte, chamada ponte de hidrogênio, que liga uma cadeia de filamentos à outra.

As bases nitrogenadas do DNA são: a Adenina, a Guanina, a Citosina e a Timina.

Se tentarmos localizar o DNA, veremos, como diz Richard Dawkins, que nosso DNA mora dentro de nosso corpo, e não se concentra em uma parte específica do corpo, mas é distribuído entre as células. Curiosamente, existem, diz Dawkins, cerca de um milhão de bilhões de células constituindo um corpo humano médio e, com algumas exceções, cada uma dessas células contém uma cópia completa do DNA daquele corpo.

O DNA é, dos ácidos nucléicos, o que instiga mais a curiosidade, pelas suas características e pelas suas várias funções.

Na molécula de DNA, as quantidades de adenina e timina, bem como as de guanina e citosina, são iguais.

A longa molécula do DNA armazena grande quantidade de informações. Ao comandar a produção de proteínas, controla a estrutura e o funcionamento das células. Pode duplicar-se, gerando copias perfeitas de si mesma; no entanto, sua seqüência de nucleotídeos sofre alterações (mutações) que podem modificar a síntese de proteínas.

Nas células eucarióticas, a maior parte do DNA concentra-se no núcleo, associada a proteínas, como constituinte dos cromossomos. No citoplasma, o DNA também pode ser encontrado em mitocôndrias, cloroplastos e associados aos centríolos.

Durante a duplicação, as duas cadeias separam-se pelo rompimento das pontes de hidrogênio entre as bases nitrogenadas, por ação da enzima DNA-polimerase, que por sua vez utiliza a seqüência de bases de cada cadeia como molde para a montagem de 
uma cadeia nova: em frente a uma adenina, a enzima coloca um nucleotídeo timina; em frente a uma citosina, a enzima coloca um nucleotídeo guanina.

Complementando o processo, cada uma das novas moléculas de DNA tem uma cadeia recém-formada e uma que é remanescente da molécula inicial; por isso, a replicação do DNA é considerada semiconservativa.

A partir das pesquisas sobre o DNA e suas funções, os cientistas podem hoje manipular os genes diretamente, sob formas cada vez mais sofisticadas. É possível, por exemplo, extrair o DNA de uma célula, fragmentar esse DNA, separar as partes contendo alguns genes específicos e introduzir esses genes em outro organismo vivo, segundo Amabis. É o que faz a Engenharia Genética, identificando um gene, isolando-o e multiplicando-o a partir de diversos organismos vivos.

A identificação genética de um animal, por exemplo, pode ser feita hoje a partir de um simples segmento de DNA encontrado em um osso. Esse segmento, de acordo com o relato de Amabis, pode ser mil vezes multiplicado até se produzir uma quantidade de DNA que seja suficiente para a identificação.

Por outro lado, uma espécie pode receber genes de um ser vivo de outra espécie - isso vem sendo feito há muito tempo com plantas - e, assim, essa espécie é instruída a produzir substâncias novas, a partir do gene recebido.

Os estudos do DNA já levaram a Engenharia Genética à técnica da clonagem, inclusive em bactérias e vírus.

Modernamente, o que mais vem chamado a atenção do mundo é o Projeto Genoma. Este é um projeto internacional, em que cientistas de várias partes do mundo juntaram esforços e intercambiaram pesquisas com o objetivo de traçar o 'mapa' do organismo humano. O esperado é que se possa detectar, através da decrifração dos códigos do DNA, todas as possíveis doenças que o homem possa ter e como mudar a orientação daquele organismo, eliminando-as.

Outro uso do DNA, amplamente difundido, é em várias questões da Medicina Legal. Segundo o laboratório Diagenix, o exame de paternidade é um dos recursos mais utilizados pela Justiça hoje, a partir de técnicas que empregam o exame do DNA. Isso pode ser feito em situações tais como:

- bebê ainda está dentro do útero (retira-se um pouco do líquido amniótico para teste).

- O bebê já nascido, do qual se pode tirar uma amostra da placenta ou uma amostra de sangue se o exame for realizado tempos depois do parto. 
- O pai é vivo (em ambos os casos acima) - nesse caso, retira-se uma amostra de sangue e faz-se a comparação do resultado com resultado obtido do bebê.

- O pai é falecido - nesse caso, pode-se extrair uma amostra do DNA a partir da medula de um osso longo, como o fêmur, ou um fio de cabelo, fazendo-se também a comparação.

Para se confirmar a inocência ou a culpa de um acusado de crime ou de violência sexual, desde que tendo meios de comparação entre o material encontrado na vítima e o material encontrado em um suspeito, exames de DNA também são realizados com margem de acerto de $100 \%$.

O conhecimento da seqüência de genes completa do DNA de um organismo permite que se faça uma abordagem sistematizada para definir os seus componentes genéticos.

A seqüência de genes permite o acesso às estruturas completas de todos os genes, incluindo aquelas sem função conhecida. Além disso, a sequiência é uma fonte de informação extremamente rica para o desenvolvimento de estudos biológicos adicionais do organismo e para o estudo da evolução das espécies.

O poder desta abordagem foi amplamente demonstrado pela determinação das seqüências de genes em vários organismos microbianos. O próximo passo é obter a sucessão completa de todo o genoma humano.

Pesquisadores de vários países, trabalhando em conjunto, conseguiram pela primeira vez clonar uma seqüência de genes em um cromossomo humano, o de número 22 , o segundo menor dos cromossomos.

Utilizando uma técnica de clonagem, os cientistas geraram a maior seqüência conhecida até o momento do DNA humano. A análise desta seqüência antevê as informações que serão reveladas dos cromossomos seguintes.

Um estudo realizado com gêmeos univitelinos comprovou que há diferenças genéticas entre eles. Essas diferenças aparecem com o decorrer dos anos, e o estudo mostra que as mudanças não ocorrem no código genético, mas são mudanças químicas ocorridas depois do nascimento alteram a forma como os genes se manifestam - o processo é chamado de epigenia.

Coma a ajuda dessa pesquisa pode-se ajudar a explicar como o meio ambiente e os genes interagem para produzir doenças e diferenças entre as pessoas.

O mais importante é que foi constatadas uma associação direta entre diferenças epigenéticas notáveis e a idade dos gêmeos univitelinos: os pares mais jovens eram 
epigeneticamente similares, enquanto os pares mais velhos apresentavam diferenças claras.

Gêmeos idênticos ocorrem a cada 250 nascimentos. E, apesar de o código genético deles ser igual, há diferenças claras que são facilmente observáveis por quem convive com os dois.

Um exemplo: doenças psiquiátricas como a esquizofrenia e o transtorno bipolar não acontecem de forma uniforme nos gêmeos univitelinos.

Há várias explicações possíveis para essas observações. Mas uma delas é a existência de diferenças epigenéticas. $\mathrm{O}$ estudo dá embasamento a teorias segundo as quais fatores ambientais, como o fumo, a dieta e a prática de exercícios físicos, afetam diretamente o DNA. 


\section{ARTIGO 3}

\section{$\underline{\text { Projeto DNA }}$}

por Carla

\section{Resumo}

Valorizar os adeptos descobrimento da ciência, tais como o desenvolvimento da genética, encontramos um ser a inda muito desconhecido, um tanto antigo e muito discutido suas relações hoje, o DNA. Entender o complexo desse imenso universo é mergulhar em uma série de informações e experimentos ainda realizados no passado para podermos compreender melhor o imenso mistério que o cerca DNA.

Compreender esse mundo talvez não seja uma tarefa fácil para todos os seres. Essa herança biológica se baseia na transmissão de informações hereditárias - os genes, passados de geração para geração, que possibilita reflexões da continuidade da vida e sobre a natureza entre os seres vivos ao longo dos anos.

Compreender seus princípios teóricos que venham a desvendar a hereditariedade e suas variações em manifestações genéticas sequer utilizar conhecimentos para poder - se entender situações reais; Como exemplo a aplicação dos estudos e experimentos nos casos de genes letais (provadores de doenças), características genéticas humanas de interesses médicos, venham atuar de forma positiva na prevenção e no tratamento de certas doenças que ocorrem de incompatibilidade genética. Aplicar esses conhecimentos não foi tarefa fácil para os estudiosos do passado, assim como não é atualmente.

A visão da ciência em utilizar seus experimentos e pesquisas como ponto positivo incomoda a muitas áreas da nossa sociedade, em aspectos éticos, morais, políticos e religiosos. As diferentes visões destas pesquisas implicam no desenvolvimento da ciência. Fazendo com que haja um atraso no conhecimento científico. Seu foco é poder utilizar o DNA como algo positivo para esta sociedade, porém ao analisarmos a verdadeira face da sociedade veremos o porquê te tanta preocupação com o desenvolvimento da genética, especificadamente o DNA.

A seguir você terá um visão melhor sobre DNA suas principais discursões relacionadas aos parágrafos acima.

\section{DNA - Um mistério para a ciência}

Há alguns anos atrás começou a estudar uma molécula ainda no entanto desconhecida, conhecida como ácido desoxirribonucléico (DNA). Segundo James Watson e Crick essa não era um a molécula, pois na realidade guardava o segredo da existência da vida, a 
chave da natureza das coisas vivas que armazenavam e transmitiam informações hereditárias que passam de geração pra geração mas como entender esse inacreditável mundo da célula? Isso só seria possíveis ao longo dos anos onde foram se desenvolvendo grandes experimentos.

Em um dos estudos foi se revelado as moléculas de DNA consistiam em múltiplas coisas de uma única unidade conhecida como, nucleotídeo, que ocorre em quatro formas: adenina (A), timina (T), guanina (G) e citosina (C). Mais como elas se encaixavam? No Estudo de J. Wele chegou a seguinte conclusão que as duas estavam unidades pelo pares formados entre elas, porém só confirmou sua teoria após a resposta de Crick, que até o presente momento fazia jus a idéia de J.W de pares implicava com a estrutura de uma dupla-hélice, com duas cadeias moleculares em direções opostas. Tudo o que eles sabem sobre DNA e suas propriedades complementavam suas teorias. Chegando assim a organização da molécula, apesar de sua descoberta ainda falta-se responder umas das perguntas mais antigas feitas pela Biologia: como informações hereditárias as armazenadas e como sua reduplicação?

Com a descoberta Crick e Watson colocou um fim da discursão mais antiga da Ciência: será eu é vida possui essência mística ou mágica? Ou é uma ação química realizada em laboratórios, sendo produto de processos químicos, físicos? Exista algo mais divino dentro do amplo da célula capaz de lhe dar vida? Sua descoberta "pos "um" não" definitivo nesta questão. A teoria da evolução, segundo Darwin, mostrou que todas as formas de vida estão inter-relacionadas umas com as outras, isso explica que o mundo do DNA vai além do físico e químico. Como exemplo moscas que põem ovos, a idéia de geração espontânea está totalmente excluída. Com relação a esses processos aplicamos o vitalismo (a crença de que mecanismos físico-químicos não saberiam explicar a vida e seus processos), porém essa crença fez com que muitos biólogos ainda acreditassem na seleção natural aplicando força espiritual para justificar a vida. Os físicos, julgavam desnorteante essa desalinhada complexibilidade que viessem a explicar os processos das células, os que reguem os fundamentos da vida, muitos, talvez explicar isso fosse além das Leis da química e física.

A dupla-hélice foi importante trazer de volta os pensamento iluminista há célula. Com o pensamento intelectual de Copérnico retiramos os seres humanos do centro do universo e prosseguindo com Darwin que os seres humanos são macacos a única diferença é que são modificados, finalmente chegaríamos a essência da vida. Não muita diferença, nada 
em especial a dupla-hélice era simples, sucinta com uma mensagem prosaica que provou que a vida é uma questão química.

Apesar de entenderem o intelectual de seu descobrimento, não podiam prever qual o impacto disto na ciência e na sociedade. A chave da biologia molecular, tinha uma nova cara científica que após cinqüenta anos seus avanços foram espantosos. Gerando assim uma nova concepção de processos biológicas, mais também traz ao mundo de hoje que o DNA não é somente algo que vem impactando a medicina, agricultura e direito. $\mathrm{O}$ DNA hoje não fica apenas atrás de aventais brancos em obscuros do laboratórios de universidades; ele afeta a todos nós.

\section{DNA, dinheiro e indústria}

Quando dizemos que o DNA não interressa mais somente aos "aventais brancos" estamos falando de uma verdade pura, pois hoje ele faz parte de todos nós.

O DNA hoje gera milhões de reais, dólares, euros; Visto que a partir do momento em que se foi permitido o desenvolvimento das pesquisas houvesse maior entre os cientistas e a relação estabelecida por governos e a indústria.

Com a aprovação do Projeto Genoma Humano pelo presidente norte-americano Bill Clinton, permitiu com que a ciência genética (DNA) torna-se uma ciência "adulta" com orçamentos e resultados de gente grande, despertando assim o interresse de milhões de empresários, farmacêuticos, ect.

Ao longo dos anos, apesar das pesquisas terem um grande efeito até o presente momento positivo, o investimento do governo em tecnologia de equipamentos e maquinas que ajudassem aos médicos, biólogos, pesquisadores, ect em suas pesquisas fez com que eles se "maravilhassem" em poder saber que suas pesquisas estariam alcançando um nível maio, podendo assim descobrir realmente como funcionava o DNA, trouxe além uma determinada repreensão por parte dos médicos, biólogos, geneticistas, ect.

Com o desenvolvimento tecnologia os cientistas sentiram-se reprimidos pelo fato de terem virem que o DNA não era apenas um material que transmitia informações genéticas, mas também que as mensagens genéticas dos genes podiam ser copiadas, formado assim um outro ser. Além do mais tinha-se as células embrionárias que poderiam se transformar em qualquer célula ou tecido do corpo humano, ajudando assim pessoas que sofreram acidentes e ficaram paraplégicas, que sofriam de alguma doença genética, ect. Com o descobrimento os cientistas viram que apesar de ser positivo pra eles teriam um impacto violento no governo e na indústria. Quando se foi 
anunciado a descoberta percebeu-se que o desenvolvimento das pesquisas em busca de cura, teriam em retardamento. Seria como se os milhões de medicamentos produzidos e o dinheiro que o governo ganhava com a compra e venda desses medicamentos fossem jogados na lata do lixo. Conclui-se que apesar do grande avanço das pesquisas científicas governo e indústria opõem em lados que implicam no seu desenvolvimento, isto tudo porque há dinheiro, poder, riqueza e uma serie de outros fatores envolvidos, enquanto eles discutem-á uma imensidão de pessoas ansiosas em receber a cura, mas não podem por causa desta discursão.

\section{Células embrionárias e as ações práticas da ciência}

Como todos nós sabemos a ciência e suas evoluções têm sido algo de muita crítica pela sua ação prática, clonagem embriões, mutações, ect. A principal discursão atual que predomina congressos e conversas é a utilização das células embrionárias para ajudar pessoas na prevenção de doenças, na cura, mas há vida nesta célula ou não? Por não ter os sistemas "normais" não têm vida? Não pode ser alguém? Isso é a principal fonte de discursão: A VIDA.

Células embrionárias são células resultantes de uma relação sexual sem prevenção, onde o espermatozóide é fecundado no óvulo, formando assim a célula embrionária que para a religião já há vida, por causa da consumação do ato (célula já formada), porém segundo a ciência não há vida por não ter sistemas. É algo que causa polêmica, a ciência e suas consumações, neste caso a igreja poderá estar ultrapassando seus limites, enquanto isso poderá salvar vidas? Até que ponto a ciência pode ir para salvar vidas? Até onde a religião pode interferir naquilo que a ciência faz? São perguntas difíceis de serem respondidas por todos nós...

A religião acusa que a ciência pode agir, desde que não se aflija seus princípios éticos e religiosos (bíblicos), o que para a ciência é desnecessário, por que se muitos ligassem realmente para aquilo que a religião diz não farão nada, assim aconteceu quando com as teorias sobre DNA, CRIAÇÃO DO UNIVERSO, ECT, muitos viram-se “obrigados" a desacreditar nas teorias religiosas ou qualquer coisa que ligasse á elas. Concluísse, pois que apesar das grandes discursões de suas ações a ciência nos ajuda em muito, através daquilo que tem feito, mas precisamos analisar seus parâmetros e impactos para que não venhamos julgar errado aquilo que ela tem faz. A necessidade de analisar e não julgar precipitadamente é também não deixar somente a igreja intervir, mas nós também colocando aquilo que pensamos, a fim de que as filas de pessoas que esperam por 
órgãos sejam diminuídas, que pessoas com diversas doenças possam ser curadas, e acima de tudo a ciência seja usada para o bem.

\section{Referências}

DNA: the secret of life

Watson, James D., 1928 DNA - O Segredo da vida com Andrew Berry. Tradução

Carlos Afonso Malferrari - São Paulo: Campainha das Letras, 2005.

Bibliografia.

ISBN: 978-359-0716-2

EDITORA: Schwarcz $3^{\text {a }}$ reimpressão

Revista Plenitude,

Diretor-Geral: Sidney Costa

No. 165 Novembro de 2008 Ano 29

Editora: Unipro

Publicação Universal Produções

ISSN: 1414-0485

Artigo das páginas 12 e 13 - Vida Criada em Laboratório

Cientistas estão brincando de Deus

Revista Graça - A revista da fé cristã

Diretor-executivo: R. R. Soares

Show da Fé Ano: 6 No. 81

Graça Editorial

Publicação mensal da Graça Artes Gráfica e Editora Ltda.

ISSN: $1516-8611$

Artigo: Darwin 1 e Darwin 2

Pagina 28

Biologia das Populações - Componente curricular: Biologia - Livro do Professor

José Mariano Amabis - Doutor em Biologia/Genética pelo Instituto de Biociências da Universidade de São Paulo

Gilberto Rodrigues Martho - Licenciado em Ciências Biológicas pelo Instituto de Biociências da Universidade de São Paulo 
Volume: $32^{\text {a }}$ Edição São Paulo 2004

Editora: Moderna

Capítulos 1. A Origem da Genética

1.2. As primeiras idéias sobre herança biológica

Páginas 2-3-4

Quatro de Consultas. Marcos da Genética no século XX

Páginas $11-12-13-14$

Capítulo 2. A lei da segregação genética

Páginas $18-19$

*Dedução da lei da segregação dos fatores

Paginas 24-25-26-29-30

Capítulo 7. Do genótipo ao fenótipo. Como se expressam os genes

Páginas 132-133-134-135-136-137

*Código Genético

Páginas 143-144

*Leitura - Um conceito em apuros

Páginas 148-149

Capítulo 8. Aplicações do conhecimento genético

Páginas 156-161-162-163-166-167-168-169-170-173-174-175-176

*Leitura - Desdobramentos do Projeto Genoma Humano

Páginas 177-178

Biologia - Livro do Professor

J. Laurence Bacharel em Ciências pela Universidade São Judas Tadeu

Volume Único

Editora: Nova Geração

Capítulo 35. Genética - primeira lei de Mendel

Página 595

Capítulo 38. Genética pós-Mendel

Páginas 628-629-630-631-632-633

*Leitura - Genoma: desafios filosóficos para nossa geração

Página 641

Capítulo 39. Biologia Molecular do gene: síntese protéica e engenharia genética

Páginas 646-647-648-649 
*Mutações no material genéticoa

Páginas 651-652-653-654

Unidade 6 Capítulo 41. Teoria da evolução, especiação e genética de populações

*Sugestões de atividades complementares

Paginas 110-111 


\section{ARTIGO 4}

\section{DNA}

por Simone

\section{Introdução}

Pertencente ao grupo dos ácidos nucléicos o DNA (ácido desoxirribonucléico) é formado por nucleotídeos, sendo portanto polinucleotídeos.

Esses nucleotídeos são formados por três partes: um fosfato, um açúcar e uma base nitrogenada.

O DNA encontra-se localizado no núcleo das células eucarióticas e é o material genético responsável por todas as informações do nosso organismo.

A cada dia, o DNA passa a ser alvo de novas pesquisas e descobertas, que geram conflitos e mais questionamentos a cerca desse assunto.

O DNA nos possibilita o acesso à várias informações. A partir dele pode-se descobrir inúmeras características genéticas de um indivíduo, sendo que com excessão dos gêmeos monozigóticos (univitelinos), o DNA nunca é igual, ou seja difere de pessoa para pessoa.

Com isso, o DNA torna-se, cada vez mais, um grande gerador de polêmicas, pois aborda assuntos que diante da sociedade não são compreensíveis, como no caso dos alimentos transgênicos, da clonagem, e até mesmo em algo que se torna cada vez mais comum, como o teste de paternidade.

O artigo a seguir têm como objetivo esclarecer algumas dúvidas a cerca do DNA, tratando de forma clara e objetiva algo que a partir de agora mais simples e fácil de se compreender.

\section{DNA}

DNA é o material genético responsável pela determinação das características de um organismo. O DNA (ácido desoxirribonucléico) pertence ao grupo dos ácidos nucléicos, possui esse nome justamente por ser encontrado no núcleo das células e por apresentar característica ácida.

O DNA é formado por nucleotídeo, sendo assim é um polinucleotídeo.

Cada nucleotídeo é constituído por três unidades: um radical fosfato, uma pentose e uma base nitrogenada. 
A pentose no DNA é chamada sempre de desoxirribose. Quanto ao fosfato é originado do ácido fosfórico, por perda de átomos de hidrogênio.

As bases nitrogenadas são separadas em duas partes: púricas e pirimídicas.

Púricas: Adenina (A) e Guanina (G).

Pirímidicas: Citosina (C) e Timina (T).

Os nucleotídeos do DNA terão sempre a desoxirribose, o fosfato e uma das quatro bases nitrogenadas $\mathrm{A}, \mathrm{G}, \mathrm{C}$ ou $\mathrm{T}$.

No DNA o número de bases púricas e o número de bases pirimídicas são sempre iguais, segundo as análises de E. Chargaff. Significa dizer que a soma de adeninas com guaninas é igual à soma de citosinas com timinas.

Estas bases são ligadas entre si por meio de bases de hidrogênio, sendo que a adenina se liga a timina por meio de duas pontes de hidrogênio, enquanto que a guanina se liga a citosina por meio de três pontes de hidrogênio.

Um estudo realizado por M.M.F. Wilkins e R. Franklin, sobre a difração de raios X, indicou que o DNA é uma estrutura ordenada, como se estivesse enrolada em torno de um eixo imaginário.

Com base nesse estudo, James Watson e Francis Crick, propuseram que a molécula de DNA existe como uma dupla hélice, onde as cadeias polinucleotídicas estão entrelaçadas umas nas outras na forma de um espiral.

Segundo Watson e Crick essas cadeias polinucleotídicas formam uma estrutura semelhante a uma escada em espiral, onde cada corrimão da escada é formado pela desoxirribose e o fosfato e os degraus uma dupla de bases nitrogenadas, sendo uma de cada cadeia, ligadas por meio de pontes de hidrogênio.

O DNA tem a capacidade de se duplicar, onde de uma única molécula de DNA podem ser obtidas duas novas moléculas iguais as que a originou. $\mathrm{O}$ processo de duplicação ou replicação do DNA é do tipo semiconservativo, pois ao serem formadas as novas moléculas-filhas parte da molécula que a originou é conservada.

\section{Tipagem genética}

A tipagem genética, entre outras coisas, é utilizada em situações em que se envolve a justiça. Dessa forma é possível a partir do DNA, poder associar a cena do crime ao real criminoso e até mesmo em casos de estabelecimento de vínculos genéticos, como é o caso dos testes de paternidade, por exemplo.

Assim, para que tais situações sejam resolvidas da melhor maneira possível e com a maior clareza necessária, o DNA é a principal base científica para a tipagem genética. 
Em caso de crimes, por exemplo, fatores externos como o contato do material genético com a luz solar, fungos, bactérias, etc., podem fazer com que esse material sofra alguns danos. Entretanto, tecnologias avançadas podem minimizar os erros em relação a alguns resultados.

Assim como o DNA, a hereditariedade e as regiões hipervariáveis da molécula de DNA também são fatores que auxiliam nas respostas da tipagem genética.

Os métodos utilizados para o estabelecimento de tipagem genética são bastante precisos, portanto por mais que haja poucas moléculas de DNA disponíveis, ainda assim é possível chegar a uma conclusão precisa.

No Brasil, o sistema de fiscalização dos resultados de exames, ainda é falho. Muitas vezes a também falta de informação de alguns profissionais da área, que pensam que os testes são infalíveis, acaba por interferir em alguns julgamentos, portanto é de extrema importância ressaltar que por mais que tudo leve a crer que o resultado é plenamente real e verdadeiro, nunca poderá se afirma com $100 \%$ de certeza.

\section{Doenças genéticas e diagnóstico pré-natal}

As doenças genéticas são, em geral, incuráveis podendo apenas ter algum tipo de tratamento.

O tratamento mais eficaz para esses tipos de doenças é a terapia gênica, que provoca uma alteração no DNA do portador da doença, através de um vetor, que pode ser um retrovírus, por exemplo. Porém, essa técnica pode ter alguns problemas como por exemplo a dificuldade de atingir o tecido alvo e seu potencial oncogênico.

Entretanto, em 1990 por meio da terapia genética foi possível a cura de uma criança cujo sistema imunológico era prejudicado pela falta de uma enzima.

A cada dia que passa, aumenta-se as esperanças de novas descobertas de genes associados a tais doenças. Supõe-se que aproximadamente 200 genes do corpo humano estejam associados a pelo menos 20 das doenças mais comuns entre a população.

Com os avanços tecnológicos, hoje em dia, é possível logo no início da gestação descobrir se o feto é portador de alguma doença hereditária.

O diagnóstico pré-natal é apresentado a partir do teste de células fetais, onde a partir do fluido amniótico é possível detectar anormalidades já no início da gestação.

Um aconselhamento genético é feito aos pais, que poderão decidir se irão ou não seguir a diante com a gestação.

\section{Bibliografia}


- Biologia: Volume único: ensino médio / Augusto Adolfo, Marcos Crozeta e Samuel Lago / Editora Lago / Coleção Vitória-Régia.

- Biologia: Volume único / José Arnaldo Favaretto, Clarinda Mercadante / Editora Moderna.

- www.ortigonal.com/direito-artigos/o-dna-vai-ao-tribunal-o-impacto-das-tipagensgeneticas-380007.html

- http://adam.sertaoggi.com.br/encyclopedia/ency/article/002053.htm

- www.ufrgs.br/bioetica/biogenet.htm

- http://www.geocities.com/ esabio/genoma/doencasgeneticas.htm

- http://www.portalmedico.org.br/revista/bio2u5/odnacomounica.htm 


\section{ARTIGO 5}

\section{DNA}

por Mônica

\section{Introdução}

DNA, ácido desoxirribonucleico presente no núcleo de todas as células eucarióticas num espaço denominado carioteca.

Alvo, de décadas de estudos e descobertas revolucionárias, que fizeram seus maiores marcos na humanidade.

Material genético, que contém todas as nossas características, visíveis e invisíveis.

Gera polêmica, com assuntos relacionados como clonagem, alimentos transgênicos, etc., pode ser usado em descobertas de curas para doenças, identificação pessoal e muito mais.

O conhecimento é gerado por meio do questionamento, gerado pela dúvida, e muitas vezes na ciência a verdade é relativa, o que mostra a importância de sempre buscar dados corretos e atuais em qualquer assunto, inclusive DNA.

\section{Ácido desoxirribonucleico (DNA)}

O DNA é encontrado no núcleo de todas as células eucarióticas. Há também os cromossomos que são formados por duas "fitas" de moléculas, nele está contida muitas informações inclusive a de hereditariedade. $\mathrm{O}$ ser humano possui 46 cromossomos.

Segundo o modelo de Watson e Crick a molécula do DNA trata-se de uma "duplahélice", formada por duas cadeias de nucleotídios seriam uma espécie de sub-unidades do DNA.

É importante saber, que um nucleotídio é formado por um fosfato, uma pentose (açúcar) e uma base nitrogenada.

A pentose também é responsável pela formação de RNA, o que diferencia é que no DNA a pentose $\left(\mathrm{C}_{5} \mathrm{H}_{12} \mathrm{O}_{5}\right)$ é a desoxirribose e no RNA a ribose.

As bases nitrogenadas são quatro: adenina, guanina, citosina e timina, que por sua vez, dividem-se em bases púricas e bases primídicas.

Segundo estudos realizados por Erwin Chargaff, nota-se que as bases nitrogenadas do DNA $50 \%$ são púricas e $50 \%$ prímidicas, ou seja, a soma de adeninas com guaninas é igual a soma de citosina com timina.

Além disso, Chargaff chegou a conclusão que a adenina é igual a Timina e a Citosina é igual a Guanina. 
Watson e Crick, também confirmaram que cada "hélice" do DNA é formada por uma cadeia que sucedem de forma alternadamente, a desoxirribose de um nucleotídio e o grupo de fosfato do seguinte.

Cada "ponte" de uma hélice a outra é formada por um par de bases nitrogenadas, ligadas por hidrogênio, sempre uma adenina e uma timina, ou uma guanina e uma citosina.

\section{Funcionamento do DNA}

A fita dupla que forma o DNA divide-se em vários segmentos. Estes grupos de elementos são chamados de genes. Cada gene produz proteínas que são os componentes que fazem o nosso corpo por dentro e por fora.

Temos genes responsáveis pelos anticorpos, que se encarregam da função de defesa do organismo, a partir da identificação de moléculas, partículas ou micro-organismos estranhos no corpo, denominado antígenos.

Também há a melanina, que é um pigmento produzido por uma célula de nosso corpo chamada melanócito (determina a cor da pele) e insulina, o responsável pela redução da taxa de glicose no sangue, é essencial no consumo de carboidratos, na síntese de proteínas e no armazenamento de lipídios (gorduras).

Segundo o monge e cientista austríaco Gregor Mendel, através de estudos realizados com ervilhas, deduziu:

- As características hereditárias são determinadas por fatores herdados do pai e da mãe na mesma proporção;

- Tais fatores se separam na formação dos gametas;

- Indivíduos de linhagens puras possuem todos seus gametas iguais, ao passo que híbridos produzirão dois tipos distintos, também na mesma proporção.

Não existem pessoas que possuem o mesmo material genético, só no caso de gêmeos univitelinos, ou idênticos. Isso só acontece em cada 1/3 no caso de gêmeos. Formam-se quando um único óvulo, fecundado por um só espermatozóide, sofre posteriormente uma divisão. Logo, eles têm a mesma carga genética (DNA) e mesmo sexo.

Apenas $10 \%$ a $15 \%$ dos gêmeos idênticos possuí placetas separadas. Nos demais casos, há somente uma placeta.

Não existe explicações concretas.

\section{Clonagem}

Clonagem se trata de cópias fiéis, seres que compartilham o mesmo material genético (DNA) sendo originado da divisão do óvulo fecundado. 
O primeiro mamífero clonado, foi a ovelha Dolly, nos anos de 1995 e 1996. Porém, só foi publicado em 1997.

A clonagem de seres humanos gera muitas controvérsias.

Segundo o americano Woff, que trabalha em pesquisas de clonagem no Centro de Primatas do Oregon, é ridículo pensar que não é possível clonar seres humanos.

Em 1992, Jerry Hall e Robert Stillman, da Universidade de George Washington, clonaram 48 embriões humanos, entretanto lhe deram apenas seis dias de vida.

Atualmente, o governo americano quer considerar ilegal a clonagem de humanos; Segundo Clinton (Presidente da Comissão Nacional de Bioética dos Estados Unidos) não é imoral usar a clonagem em benéfico da humanidade, porém é inconcebível cogitar o nascimento de crianças clonadas.

A Igreja, se posiciona contra a clonagem, defende a ideia da existência da vida desde a fecundação, como algo divino. A clonagem, em seu ponto de vista, seria interferir nas fontes naturais da vida humana.

Embora haja todas essas polêmicas, um fato é certo: a clonagem pode trazer algumas vantagens, como a preservação de animais em extinção; o desenvolvimento de animais imunes a algumas doenças que são contagiosas; clonagem de células humanas para tratamento de doenças como: pâncreas para diabéticos e de células do sangue para os leucêmicos.

\section{Engenharia genética}

A engenharia genética, é um conjunto de tecnologias baseadas em conhecimentos sobre as características hereditárias, utilizadas para resolver problemas diversos na medicina, agricultura, pecuária e outras áreas. Trabalha na manipulação dos genes.

Vem fazendo avanços em estudos referentes ao DNA e outros assuntos, trazendo grande desenvolvimento em várias áreas.

Com este avanço, surgiram os alimentos transgênicos, clonagem, e muito mais; como, a inseminação artificial e a fertilização in vitro.

A inseminação artificial, que é um recurso utilizado para realizar a fecundação; para que isso ocorra há uma deposição artificial do sêmen no trato reprodutivo feminino. A inseminação pode ser feita no cérvix (inseminação cervical) ou no útero (inseminação intrauterina).

A fertilização in vitro, é a tentativa de reproduzir em laboratório, as condições necessárias para que ocorra a fecundação e as primeiras etapas do desenvolvimento embrionário. 
Ambas são alternativas para problemas de fertilização; e são possíveis graças a estudos realizados com DNA.

Atualmente, a utilidade do DNA é enorme, vemos no caso de identificação de pessoa, considerado um dos maiores avanços do século na área da genética. Pode ser usado em casos de confirmação de paternidade, casos criminais envolvendo estupro e rapto, identificação de genes envolvidos em doenças como câncer, desenvolvimento de medicamentos, etc.

A engenharia genética, possui grande poder, mas suas ações precisam respeitar a bioética, ética aplicada chamada também de ética prática, "que visa" "dar contar" dos conflitos e controvérsias morais implicada pelas práticas no âmbito das ciências.

A engenharia genética, gera polêmicas. Segundo o jornalista científico Marcelo Leite, "a engenharia genética tem, sim meios de produzir efeitos espantosos sobre seres vivos, mas nem por isso se encontra na posição de ditar-lhes metabolismos e comportamento absolutamente previsíveis e controlados".

A Igreja também possui sua posição, sempre com caráter religioso.

Em suma, a engenharia genética está aí, cada vez mais fazendo novas descobertas e revolucionando o campo da genética, em busca do conhecimento sobre a maquinaria mais perfeita e complexa que existe: o ser humano.

\section{Fontes pesquisadas}

http://www.artigonal.com/direito-artigos/o-dna-vai-ao-tribunal-o-impacto-das-tipagensgeneticas

http://www.clonagemigreja.blogspot.com

http://pt/wikipedia.org/wiki/Engenharia-gen/C3\%Agtica

http://ww1.folha.uol.com.br/folha/pubifolha/ult100037u351823.shtmail.

http://ich.unito.com.br/materia/view/214

http://drauziovarella.ig.com.br/entrevista/genes4.asp

http://www.brasilescola.com/biologia/anticorpos.htm

http://www.apele.com.br/materiais/read.asp?38

Livro: Biologia IBEP cap. 2 pág. 68 e 69 
ARTIGO 6

\section{Projeto Genoma Humano e seu impacto na sociedade}

por Soraia

\section{Resumo}

Este artigo apresenta um pouco sobre o projeto genoma humano e o impacto que ele causa na sociedade, mostrando os benefícios e malefícios. Ilustra também ponto de vista ético e científico em relação à escolha de sexo, prevenção de doenças e até mesmo a mudança de comportamento.

Incluindo as preocupações que podem vir com a conclusão desse projeto.

\section{Abstract}

This article presents a little bit about the human genome project and the impact that it causes in society, showing the benefits and harm. Also illustrates ethical point of view and scientific with the choice of sex, disease prevention, and even a change of behavior. Including concerns that may come to the conclusion this project.

\section{Introdução}

O projeto genoma tem como objetivo identificar todos os genes responsáveis por nossas características. E os resultados adquiridos mudaram muitas coisas no ramo da medicina, pois ajudara na prevenção de muitas doenças. Os remédios serão receitados de acordo com o perfil genético de cada um, assim evitara os tais "efeitos colaterais".

Mas todos esses avanços já vêm causando muitas discussões e questionamentos éticos na sociedade e muitos outros irão surgi com o tempo.

É possível dizer que um dos benefícios esperado do Projeto seria a diminuição do sofrimento humano pela idéia que possibilita diagnosticar curas e doenças, mas, também existe a o malefício um dos seria a mudança de comportamento a sociedade acabaria se transformando em "robôs", pois seriam "programados" para certas atividades.

\section{Algumas informações sobre o Projeto Genoma Humano}

Em 1990, cientistas do instituto Sanger, Na Inglaterra deram inicio ao Projeto Genoma Humano, com o objetivo de identificar as seqüências de genes e de DNA que compõem as características da humanidade.

As vantagens desse trabalho estão ligadas principalmente na área de prevenção, pois será possível saber se a pessoa terá certas doenças como diabete, câncer, Alzheimer, hipertensão, e tratá-las antes mesmo que se possa aparecer os sintomas. 
As desvantagens no sentido ético e moral, o uso indevido do Projeto pode fazer com que as pessoas percam sua individualidade, por exemplo, se num exame ver que ele poderá ter câncer no futuro isso era dificultar que ele consiga um emprego. A grande importância do PGH é sua busca pela melhora na condição de vida humana e a tentativa de tratar, prevenir ou até mesmo curar doenças genéticas com outras causas de doença.

\section{Declaração Universal do genoma humano e dos direitos humanos}

O Comitê de Especialistas Governamentais, convocado em Julho de 1997 para a conclusão de um projeto de declaração sobre o genoma humano, examinou os esboços preliminares revisto, redigidos pelo Comitê Internacional de Bioética. Ao término de suas deliberações, em 25 de julho de 1997, o Comitê de Especialistas Governamentais, no qual mais de 80 Estados estiveram representados, adotou por consenso o Projeto de uma Declaração Universal do Genoma Humano e dos Direitos Humanos, que foi apresentado para adoção na 29a sessão da Conferência Geral da Unesco (de 21 de outubro a 12 de novembro de 1997).

\section{A Dignidade Humana e o Genoma Humano}

Artigo 1 - O genoma humano subjaz à unidade fundamental de todos os membros da família humana e também ao reconhecimento de sua dignidade e diversidade inerentes. Num sentido simbólico, é a herança da humanidade.

\section{Artigo 2}

a) todos têm o direito por sua dignidade e seus direitos humanos, independentemente de suas características genéticas.

b) Essa dignidade faz com que seja imperativo não reduzir os indivíduos a suas características genéticas e respeitar sua singularidade e diversidade.

Artigo 3 - O genoma humano, que evolui por sua própria natureza, é sujeito a mutações. Ele contém potencialidades que são expressas de maneira diferente segundo o ambiente natural e social de cada indivíduo, incluindo o estado de saúde do indivíduo, suas condições de vida, nutrição e educação.

Artigo 4 - O genoma humano em seu estado natural não deve lugar a ganhos financeiros.

\section{Direitos das Pessoas Envolvidas}

Artigo 5 - (a) Pesquisas, tratamentos ou diagnóstico que afetem o genoma de um indivíduo devem ser empreendidas somente após a rigorosa avaliação prévia dos potenciais riscos e benefícios a serem incorridos, e em conformidade com quaisquer outras exigências da legislação nacional. 
b) Em todos os casos é obrigatório o consentimento prévio, livre e informado da pessoa envolvida. Se esta não se encontrar em condições de consentir, a autorização deve ser obtida na maneira prevista pela lei, orientada pelo melhor interesse da pessoa.

c) Será respeitado o direito de cada indivíduo de decidir se será ou não informado dos resultados de seus exames genéticos e das conseqüências resultantes.

d) No caso de pesquisas, os protocolos serão, além disso, submetidos a uma revisão prévia em conformidade com padrões ou diretrizes nacionais e internacionais relevantes relativos às pesquisas.

e) Se, de acordo com a lei, uma pessoa não tiver a capacidade de consentir, as pesquisas relativas ao seu genoma só poderão ser empreendidas com vistas a beneficiar diretamente sua própria saúde, sujeita à autorização e às condições protetoras descritas pela lei. As pesquisas que não previrem um benefício direto à saúde, somente poderão ser empreendidas a título de exceção, com restrições máximas, expondo a pessoa apenas a riscos e ônus mínimos e se as pesquisas visarem contribuir para o benefício da saúde de outras pessoas que se enquadram na mesma categoria de idade ou que tenham as mesmas condições genéticas, sujeitas às condições previstas em lei, e desde que tais pesquisas sejam compatíveis com a proteção dos direitos humanos do indivíduo.

Artigo 6 - Ninguém será sujeito a discriminação baseada em características genéticas que vise infringir ou exerça o efeito de infringir os direitos humanos, as liberdades fundamentais ou a dignidade humana.

Artigo 7 - Quaisquer dados genéticos associados a uma pessoa identificável e armazenados ou processados para fins de pesquisa ou para qualquer outra finalidade devem ser mantidos em sigilo, nas condições previstas em lei.

Artigo 8 - Todo indivíduo terá o direito, segundo a lei internacional e nacional, à justa reparação por danos sofridos em conseqüência direta e determinante de uma intervenção que tenha afetado seu genoma.

Artigo 9 - Com o objetivo de proteger os direitos humanos e as liberdades fundamentais, as limitações aos princípios do consentimento e do sigilo só poderão ser prescritas por lei, por razões de força maior, dentro dos limites da legislação pública internacional e da lei internacional dos direitos humanos.

\section{Pesquisas com Genoma Humano}

Artigo 10 - Nenhuma pesquisa ou aplicação de pesquisa relativa ao genoma humano, em especial nos campos da biologia, genética e medicina, deve prevalecer sobre o 
respeito aos direitos humanos, às liberdades fundamentais e à dignidade humana dos indivíduos ou, quando for o caso, de grupos de pessoas.

Artigo 11 - Não serão permitidas práticas contrárias à dignidade humana, tais como a clonagem reprodutiva de seres humanos. Os Estados e as organizações internacionais competentes são convidados a cooperar na identificação de tais práticas e a determinar, nos níveis nacional ou internacional, as medidas apropriadas a serem tomadas para assegurar o respeito pelos princípios expostos nesta Declaração.

\section{Artigo 12}

a) Os benefícios decorrentes dos avanços em biologia, genética e medicina, relativos ao genoma humano, deverão ser colocados à disposição de todos, com a devida atenção para a dignidade e os direitos humanos de cada indivíduo.

b) A liberdade de pesquisa, que é necessária para o processo do conhecimento, faz parte da liberdade de pensamento. As aplicações das pesquisas com o genoma humano, incluindo aquelas em biologia, genética e medicina, buscarão aliviar o sofrimento e melhorar a saúde dos indivíduos e da humanidade como um todo.

\section{Condições para o Exercício da Atividade Científica}

Artigo 13 - As responsabilidades inerentes às atividades dos pesquisadores, incluindo o cuidado, a cautela, a honestidade intelectual e a integridade na realização de suas pesquisas e também na paresentação e na utilização de suas descobertas, devem ser objeto de atenção especial no quadro das pesquisas com o genoma humano, devido a suas implicações éticas e sociais.

Os responsáveis pelas políticas científicas, em âmbito público e privado, também incorrem em responsabilidades especiais a esse respeito.

Artigo 14 - Os Estados devem tomar medidas apropriadas para fomentar as condições intelectuais e materiais favoráveis à liberdade na realização de pesquisas sobre o genoma humano e para levar em conta as implicações éticas, legais, sociais e econômicas de tais pesquisas, com base nos princípios expostos nesta Declaração.

Artigo 15 - Os Estados devem tomar as medidas necessárias para prover estruturas para o livre exercício das pesquisas com o genoma humano, levando devidamente em conta os princípios expostos nesta Declaração, para salvaguardar o respeito aos direitos humanos, às liberdades fundamentais e à dignidade humana e para proteger a saúde pública.

Eles devem buscar assegurar que os resultados das pesquisas não sejam utilizados para fins não-pacíficos. 
Artigo 16 - Os Estados devem reconhecer a importância de promover, nos diversos níveis apropriados, a criação de comitês de ética independentes, multidisciplinares e pluralistas, para avaliar as questões éticas, legais e sociais levantadas pelas pesquisas com o genoma humano e as aplicações das mesmas.

\section{A Genética}

Hoje em dia ainda existem confusões a assuntos relacionados à genética, muitos confundem Clonagem com o Projeto Genoma, por mais que eles sejam ligados, pois ambos tratam de engenharia genética, o clone é a cópia de um ser vivo a partir do núcleo de uma célula, e toda a seqüência de DNA da copia é idêntico ao do doador da célula, inclusive seus defeitos, O Projeto genoma procura ver a sequiência dos genes e verificar se entre essa seqüência existe um gene defeituoso para então poder substituir.

O genoma, por sua vez, poderá fornecer um “diagnostico pré-natal” de varias doenças e também de características físicas como cor dos olhos e dos cabelos, além de alguns distúrbios como psicose.

Assim o homem teria a possibilidade de escolher quais características ele colocaria ou tiraria de seu filho, ou seja, sua criação.

Esse método não seria apenas para problemas de saúde, seria também usada para aperfeiçoar as funções do corpo. É nesse meio que se percebe o motivo de varias discussões sobre a ética, dessa maneira o limite da criação humana se torna delicada "é o homem brincando de ser DEUS".

Dessa forma os genes que poderiam transmitir características indesejadas ou doenças seriam substituídos.

Naturalmente tudo isso é apenas especulação e ainda estão em fase de experimentação.

No entanto, os pesquisadores que defendem o projeto genoma usam disso como trunfo, que é a substituição de partes do código genético que poderia causar doenças. O filme GATTACA, faz uma abordagem ética e filosófica sobre uma sociedade que vive sob a engenharia genética e questiona se a chave do sucesso está realmente na seqüência do genoma de um cidadão.

Zatz (2000), fala sobre esses assuntos com mais detalhes ao analisar os genes de comportamento, escolha do sexo, doenças genéticas, identificando os mais variados pontos de vista de alguns assuntos e a dificuldade de tomar decisões vendo o bem das pessoas envolvidas e estimular a discussão ética desse assunto na sociedade.

\section{A ética e o genoma}


A informação que vem do Projeto genoma deve servir para melhorar e proteger saúde, curar ou prevenir doenças.

Além de todos esses benefícios, que por sinal são ótimos, a sociedade fica preocupada com algumas das consequiências que poderam vir acontecer.

Uma dessas preocupações é o fato que os donos das empresas possam passar a pedir teste de DNA dos trabalhadores, fazendo com que os desprivilegiados sejam excluídos da sociedade por ter a chance, que não é certeza de ter alguma doença, isso fará com que se crie um outro grupo de desempregados. Ao mesmo tempo essa divisão da sociedade, formara uma nova classe, a dos geneticamente superiores.

Dessa maneira será necessário impor limites para que não haja descriminação. Profissionais da área da saúde estão preocupados pelo fato de que milhões de pessoas possam ser rotuladas pela vida inteira como doentes, por poder apresentar no futuro alguma doença. O debate ético e social das implicações da pesquisa genética e biotecnologica tem seu ponto de tensão nos projetos de intervenção sobre a reprodução humana. Os bebês de proveta abriram o caminho para a clonagem de embriões e outras pesquisas genéticas como as que visam células-tronco totipotenciais. $\mathrm{O}$ desenho de "prever" os seres humanos com vida longa, perfeição física, ou qualquer outra característica passa a ser cogitado. Com relação à prevenção de doenças, os testes prénatais representam os testes genéticos mais antigos e mais comum. Não havendo terapia que modifique o genoma, a seleção de traços genéticos é hoje sinônimo de eliminação, não dos traços, mas de seus portadores - os embriões. As implicações bioéticas desse fato traduzem-se, também, por conflitos na esfera das decisões reprodutivas dos futuros pais. Da seleção de um gene de doença se passa a um traço, como sexo; da prevenção, ao melhoramento. $\mathrm{O}$ cenário futuro desenhado é aquele no qual capacidades físicas (estatura, força muscular), inteligência, beleza e longevidade poderiam vir a ser manipulado pela terapia/engenharia genética.

O combate às doenças e desvantagens se dá em um campo no qual a genética pode voltar-se, também, para o aperfeiçoamento e melhoramento das capacidades humanas ser mais feliz, viver mais tempo, ser mais inteligente. Essa questão implica a discussão do conceito de saúde.

\section{Escolha de sexo: menino ou menina?}

Uma outra questão que é também cauda de um certo impacto na sociedade é o fato da escolha do sexo de um futuro bebê. 
Sandra Brasil destaca duas formas de se escolher o sexo do bebê, uma é a seleção de sêmen que requer inseminação artificial tendo $70 \%$ de chance de sucesso, e a outra é através do projeto genoma é mais agressiva e exige a fertilização in-vitro, porém o índice de sucesso é de $100 \%$.

Por outro lado, a possibilidade de se determina o sexo de embriões antes de sua implantação (diagnostica pré-implantação na fertilização "in-vitro") para casais com risco de doenças genéticas que só afetam o sexo masculino (como a hemofilia ou a distrofia de Duchenne) evitaria o diagnostico pré-natal e o sofrimento de ter de interromper uma gestação no caso de fetos portadores da doença.

A base da nova técnica já é uma descoberta antiga: Que é a do cromossomo Y (sexo masculino) tem uma carga menor que a do cromossomo feminino X. A partir dessas informações um grupo de cientistas de uma clínica Americana na qual a especialização era a fertilização in-vitro, fizeram dessa forma, coloriram um esperma produzido de uma ejaculação com um corante fluorescente, depois passaram um a um espermatozóides por uma maquina que detectava a carga genética, passaram um dia inteiro fazendo este trabalho, depois de separado em dois grupos só bastava o casal escolher se queria menino ou menina.

\section{Conclusão}

Em relação ao Projeto Genoma Humano, cheguei a conclusão de que ele é um excelente avanço medicinal, pois através dele poderão prevenir e encontrar cura de muitas doenças. E no caso da mudança de comportamento, na qual usaram da medicina para deixar a pessoa mais ágil essas coisas, e também a mudança das características genéticas, a cor dos olhos, cabelo, pele entre outros. Tudo isso causaria muita descriminação, pois as pessoas acabariam deixando de lado aquelas que são "menos privilegiadas" por ter a possível chance de desenvolver uma doença no futuro, sendo que nem é certeza. Essas mudanças vêm chegando com mais rapidez, nos deixando perto de um futuro não tão distante. E realmente as pessoas estão mesmo "brincando de ser Deus".

\section{Referências}

CENTRO DE ESTUDOS GENOMA HUMANO, http://genoma.ib.usp.br/

FAPESP, $\quad$ www.agencia.fapesp.br/divulga/8552/divulgação-cientifica/dna-de$\underline{\text { montar.htm }}$

GHENTE, http://www.ghente.org/doc juridicos/dechumana.htm 
INTERPRENSA， http://www.portaldafamilia.org.br/artigos/artigo103.shtml Acessado em 16/05/2009 as 15:45

SELIVER, http://seliver.110mb.com/escola/files/biologia/Genoma_humano.pdf

TODA BIOLOGIA, http://www.Todabiologia.com/genetica/genoma.htm

UOL, http://cienciahoje.uol.com.br/1060

VEJA, http://veja.abril.com.br/160998/p_072.html

VEJA， http://genoma.ib.usp.br/noticias/noticias_vejaonline080529.php Acessado em $16 / 05 / 2009$ as $15: 52$

WIKIPÉDIA, http://pt.wikipedia.org/wiki/Projeto_Genoma_Humano

ZATZ, M, Projeto Genoma Humano e ética 


\section{ANEXO VI}

$4^{\mathrm{a}}$ fase de dados

Redação de um artigo de divulgação científica tendo como base uma entrevista a um profissional da área de genética (o assunto abordado continua sendo "DNA")

(maio e junho de 2009)

(Os artigos foram reproduzidos de forma integral, assim como a entrevista, e os nomes dos alunos foram trocados para preservar sua identidade.)

\section{ARTIGO 1}

\section{Células-tronco: Afinal, quem tem a razão?}

por Simone

Desde o ano 2005, quando foi aprovada a lei que permite as pesquisas com célulastronco embrionárias retiradas de embriões que tenham no mínimo três anos de congelamento, e mesmo antes da aprovação da lei, o assunto células-tronco é o que mais gera polêmicas e causa divergências no mundo científico.

Há aqueles que são a favor das pesquisas, outros são contra, há também aqueles que se encontram divididos e há aqueles cuja informação lhes falta. Vemos o assunto ser debatido na televisão, no rádio, estampados nos jornais e revistas e ainda assim, alguns ainda sofrem com a falta de informação, fazendo com que estes não tenha uma opinião formada em relação ao assunto e que, por esse motivo, acabam se deixando influenciar pelo lado mais comodo da situação.

Células- tronco, são células que tem a capacidade de dar origem a qualquer tecido do corpo, de acordo com a sua potencialidade.

As células- tronco podem ser tanto embrionárias quanto adultas. As células-tronco embrionárias são encontradas nos embriões, enquanto que as células - tronco adultas são encontradas em tecidos como a medula óssea, a placenta, o cordão umbilical, polpa do dente, resumindo em qualquer tecido do corpo que esteja completamente desenvolvido. As células-tronco são classificadas de acordo com a sua potencialidade, ou seja, significa dizer que nem todo tipo de células-tronco tem a mesma capacidade de diferenciação. Elas são classificadas da seguinte maneira: 
- Totipotentes: São células que tem a capacidade de dar origem a qualquer tecido do corpo, sem exceção.

- Pluripotentes: São as células capazes de dar origem a todos os tipos celulares de um embrião, com exceção da placenta e anexos.

- Multipotentes: São capazes de produzir diversificados tecidos.

- Oligopotentes: Células com uma capacidade reduzida de originar outros tecidos, mas ainda assim os originam, mesmo que pouco.

- Unipotentes: Células capazes de originar um único tecido do corpo.

O que diferencia as células-tronco de qualquer outro célula é justamente a sua capacidade de originar outros tecidos. Entretanto, há diferenças entre as células-tronco embrionárias e as células-tronco adultas, uma vez que as células-tronco adultas, tem um poder de diferenciação menor do que as células-tronco embrionárias.

As células-tronco originadas de embriões tem uma capacidade imensa de diferenciação, sendo assim é possível dizer que essas células são totipotentes, o que chama ainda mais a atenção dos cientistas para pesquisas com esse tipo de célula.

Mediante a uma enorme polêmica acerca da lei, vem em nossas cabeças à questão que não quer calar: Afinal, quem tem a razão a razão?

Difícil responder a uma questão desse gênero uma vez que somos "bombardeados" por argumentos vindos de todos os lados.

É a Igreja Católica que abomina a prática de tais pesquisas, são os cientistas que alegam querer defender a vida daqueles que realmente existem e que merecem ter uma chance de recuperação.

Com tantas explicações fica difícil tomar partido de algum lado, pois o que talvez nunca saibamos é quem realmente tem a razão.

A grande polêmica e que gera conflitos não apenas entre Igreja e cientistas, mas sim até mesmo entre os próprios cientistas, é o fato de não se saber ao certo quando se dá início à vida.

Segundo a Igreja, desde o momento da concepção o embrião já tem vida, o que pra alguns cientistas é um absurdo poder afirmar com certeza, uma vez que não está provado cientificamente onde começa a vida.

Para a ciência o período ideal para a retirada dessas células-tronco totipotentes (encontradas apenas nos embriões), seria até o período do blastocisto, que é onde o 
embrião atinge uma quantidade de 32 a 64 células e a partir daí passará a formar alguns tecidos.

A partir dessas informações dá para se ter uma idéia da quantidade de opiniões que se dividem. No entanto, sabemos que essa é apenas uma das tantas explicações para tais conflitos entre ciência e religião.

O importante de tudo isso é se informar sempre sobre o assunto, e a partir de então poder tirar as nossas próprias conclusões sobre a grande polêmica que é gerada em torno das células-tronco e a partir de então quem sabe um dia podermos ter as respostas, para tantas perguntas. 


\section{ARTIGO 2}

\section{Mais um passo na ciência, uma evolução na sociedade.}

por Andressa

As pesquisas com células-tronco, ou seja, células capazes de dar origem aos mais diversos tecidos com osso, cartilagem, nervos, músculos, dentre outros, tiveram um grande avanço nesses últimos anos, porém ainda tem quem ache que é uma afronta a vida do modo que ela é. Muitas das pessoas que são contra o uso de células-tronco são ligadas a entidades religiosas ou não têm informações suficientes para entender o assunto em toda sua extensão.

Há dois tipos de células-tronco que podem ser pesquisadas:

-As adultas: que podem ser encontradas em tecidos que já se desenvolveram, tais como a placenta, a polpa do dente, o cordão umbilical, a medula óssea, a gordura da lipoaspiração, dentre tantos outros. Essas células são capazes de reparar qualquer lesão ou dano no seu tecido de origem.

-As embrionárias: que são encontradas em embriões. Essas células são Totipotentes, ou seja, são capazes de se diferenciar em todos os 216 tecidos que formam o corpo humano, inclusive placenta e anexos embrionários.

Todos os debates ligados ao uso de células-tronco estão relacionados ao uso de célulastronco embrionárias, pois acreditam que a partir do momento da concepção (ato onde há a união do espermatozóide ao óvulo) já haja vida e sendo assim, o uso de células-tronco embrionárias seria um assassinato ou coisa do tipo.

No Brasil o uso de células-tronco embrionárias, a partir do ano de 2005, com base na lei 11.105 de Biossegurança é permitido se os embriões estejam congelados há mais de três anos ou inviáveis, com consentimento dos genitores.

Enfim, as pesquisas com células-tronco, sejam elas quais forem, estão a todo vapor, apesar de alguns empecilhos creio que quando estiverem concluídas será apenas mais um passo para ciência que avança mais e mais todos os dias, porém para a sociedade será uma evolução inigualável. 


\section{ARTIGO 3}

\section{Células-Tronco: $\mathbf{E}$ ai a favor ou contra?}

por Soraia

Muitas pessoas ainda não têm conhecimento sobre a tal "células-tronco"

E dessa forma não podem chegar a conclusão alguma, apesar de toda repercussão do assunto, mal sabem o que é.Mas,para que possam chegar a uma decisão, segue abaixo algumas informações sobre as células -tronco:

As células-tronco são definidas como células capazes de dar origem aos mais diversos tecidos do organismo, como ossos, cartilagens, nervos, músculos, entre outros.

Células-tronco embrionárias são encontradas no embrião, já as células adultas são encontradas em tecidos que já se desenvolveram, tais como placenta, polpa de dente, gordura de lipoaspiração, entre outros. Elas são classificadas em 5 tipos que são: Totipotentes: são células-tronco que conseguem se diferenciar em todos os 216 tecidos que formam o corpo humano, inclusive placenta e anexos embrionários. É o caso de Zigoto (óvulo fertilizado); Pluripotentes: são as que conseguem se diferenciar nos tecidos provenientes dos três folhetos embrionários (ectoderme, endoderme $\mathrm{e}$ mesoderme). Ex. Células da Massa Interna de um Embrião de 5-6 dias; Multipotentes: capazes de originar diversos tecidos; Oligopotentes: capazes de originar poucos tecidos; Onipotentes: capazes de se diferenciar em um único tecido.

As células-tronco embrionárias são as únicas capazes de originar tecidos proveniente dos 3 folhetos embrionários(é uma camada de células (ou tecido primitivo) que aparece no embrião animal logo após a gastrulação. Na organogênese esses tecidos primitivos vão diferenciar-se em órgãos componentes do animal).Em relação ao processo de extração,elas podem ser obtidas da massa interna de um embrião de 5 a 6 dias de fertilização.

Um dos maiores sonhos da pesquisa biomedica é aproveitar toda a potencialidade das celulas-tronco embrionarias para a cura de lesões como as de medula,e de doenças como as cardiacas,o mal de parkinson e diabetes.

Existem muitas pessoas contra o uso de células-tronco,por exemplo a igreja católica e diversos grupos religiosos,pois para eles o ser humano passa a existir a partir do momento em que o óvulo é fecundado pelo espermatozóide .E pela lei abortos são proibidos,fora algumas exceções .Os críticos das pesquisas com células-tronco baseiam- 
se também em outros 2 argumentos :na qual é possível pesquisar outros dois tipos de células-tronco que estão ,no sangue do cordão umbilical dos bebês ,e as adultas que sobrevivem organismo fundamentalmente na medula óssea no decorrer de toda a vida do individuo. Dessa forma os críticos se perguntam por que os pesquisadores não se concentram nessas linhas de pesquisas que não agridam a lei e nem os religiosos?

Além disso, os críticos dizem que as pesquisas com células-tronco embrionárias ainda esta no começo e não há garantia de que trará os benefícios prometidos. A representante da Conferência Nacional dos Bispos do Brasil, Zilda Arns disse que:

"A esperança de pessoas doentes serem curadas não vai ocorrer com células-tronco ainda por muitos anos.com certeza estão iludindo essas pessoas".

Em uma entrevista feita com uma Pesquisadora de células-tronco Maria Denise Fernandes Carvalho, foi perguntado a ela algumas coisas em relação a polemica que as células-tronco causa, e ela respondeu que " a principal polemica gerada vem as falta de informação. A parti do momento em que a população busca esclarecimento a polemica desaparece."Perguntamos a ela sobre o uso de células-tronco embrionárias e a ética com relação a ciências e ela respondeu :

"A ciência feita de maneira correta e pelo profissional sério visa sempre o bem-estar. Jamais a ciência poderá considerar antiético aquilo pode melhorar a qualidade de vida de um cidadão.’Perguntamos também a respeito da posição da igreja em relação ao uso de células-tronco,ela respondeu que as principais discordâncias originam-se da igreja. E o que pode ser feito para que isso mude, ela nos deu um exemplo do que ela faz: "eu sou cientista e católica e procuro participar na minha igreja esclarecendo informações com experiências de dentro do laboratório. Assim cada um deve fazer sua parte levando às informações corretas aos leigos".

Agora cabe a você e a sociedade decidir o que é melhor. $\underline{\mathbf{E} \text { ai a favor ou contra? }}$ 


\section{ARTIGO 4}

\section{Células- tronco: Uma agressão a vida ou um trabalho a favor dela?}

por Mônica

Atualmente é de demasiada importância manter a sociedade informada sobre o que ocorre no campo da ciência. Esta informação precisa chegar de uma forma correta, separando o mito da realidade. Um dos temas mais debatidos mundialmente, inclusive no Brasil, são as pesquisas com células-tronco.

Células-tronco são células que tem a capacidade de se transformar nos diversos tecidos do corpo humano. Sua utilização pode auxiliar no tratamento de diversas doenças como, mal de Parkinson, transplantes de Medula Óssea, mal de Alzheimer, doenças cardiovasculares, acidentes vasculares cerebrais, diabete do tipo 1 e doenças hematológicas.

Há células-tronco adultas e células - tronco embrionárias.

As Células- tronco adultas, são encontradas em diversos tecidos como o sangue, a medula óssea, o fígado, o cordão umbilical, a placenta entre outros. São capazes apenas de se transformar em alguns tecidos do corpo e ultimamente vêm sido usadas para tratar de doenças do sangue.

As Células-tronco embrionárias, por sua vez, possuem uma versatilidade bem maior, sendo capazes de se transformas em 216 tipos de células do organismo humano.

Esse tipo de células são retiradas de embriões humanos. Elas ainda não são especializadas em nenhuma função, por isso possuem este potencial pluripotente, capaz de se transforma em qualquer outro tecido do corpo humano. Pesquisas realizadas com esse tipo de células-tronco é alvo de diversas polêmicas.

Para que seja realizada a pesquisa, utilizam a fertilização in-vitro. E para obter a célulatronco embrionária há a destruição do feto. O que é visto por algumas instituições religiosas (incluindo a Igreja Católica) e políticas, como aborto ou assassinato de uma vida, já que o embrião, segundo seu ponto de vista é considerado uma.

Além do mais, argumentam que há a possibilidade de realizar pesquisas com célulastronco que não exijam a manipulação de embriões.

Por sua vez, cientistas, médicos e associações civis ligadas a estudos, defendem o uso dessas células. Argumentam que seria um grande avanço medicinal e auxiliaria no tratamento de diversas doenças. Essas pesquisas se tratariam não de uma agressão a 
vida, mas sim o trabalho a favor dela ( posição que é contrária da Igreja), já que são usados embriões que são velhos demais e não dariam origem a um ser humano.

As pesquisas com células-tronco embrionárias encontram-se no início e ainda não foram testadas em seres humanos. A cura de doenças promovidas por esse tipo de células ainda são uma promessa sem data prevista.

Em muitos países as pesquisas com este tipo de célula já foram autorizadas, é o caso da China, Israel, Reino Unido e Cingapura. No Brasil é autorizada a manipulação dos embriões descartados, permitido por a Lei 11.105 de Biossegurança em 2005.

Os E.U. A é um dos líderes de pesquisas com células-tronco, entretanto proíbe a pesquisa direta.Na Itália, todo tipo de pesquisa está proibida.

Para que seja formada uma opinião correta a respeito deste tema, é necessário informações concisas e certas, para que a população entenda e faça um correto julgamento; sabendo discernir o certo do errado, pois na mídia há diversas informações que podem estar distorcidas.
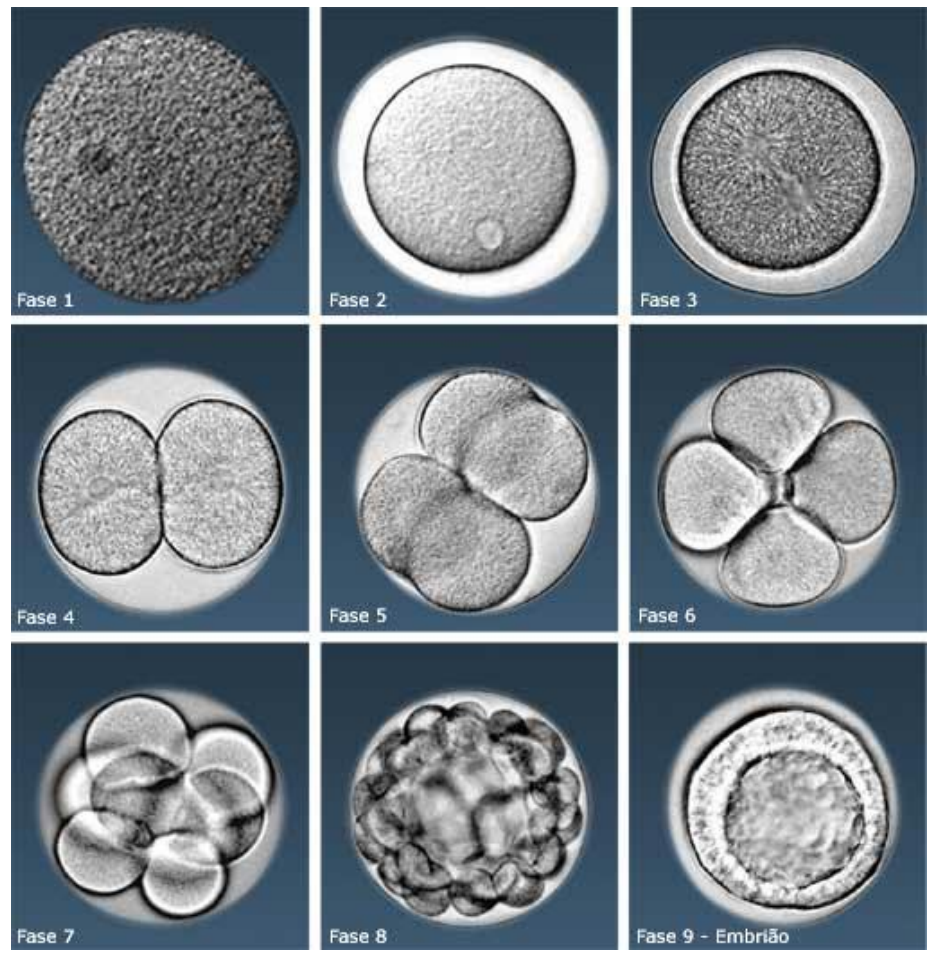

Evolução do óvulo fertilizado até a origem do embrião. 


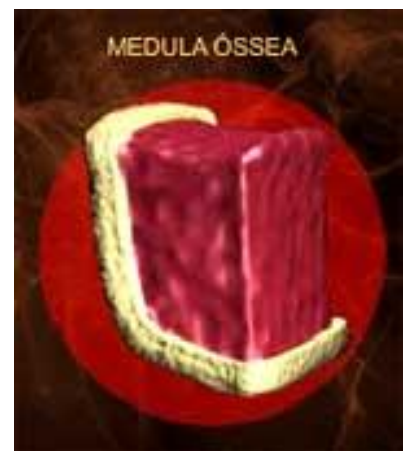

Exemplo da Medula Óssea, onde as células -tronco adultas podem ser encontradas. 


\section{ARTIGO 5}

\section{Células Tronco-Informações á população.}

por Carla

Células tronco é um assunto, bastante abordado pelas diversas mídias,sendo essas informações muitas corretas e outras não,gerando assim uma falta de informação correta por parte de todos que ouvem ou vêem aquele determinado assunto.No caso das células tronco ocorre o mesmo,a má divulgação das noticias,pesquisas, diversas dados acabam fazendo com a população não saiba distinguir o que realmente são.

Em entrevista, com a Prof ${ }^{a}$ Denise Carvalho, da Universidade Mackenzie procuramos relacionar essa falta de informação com perguntas simples que possam ajudar a todos a compreender melhor esse mundo.

Primeiro esclarecer que a definição de células-tronco é que são células imaturas,ou indiferenciadas capazes de dar origem aos mais diversos tecidos como exemplo,osso,cartilagem,nervos,etc.As células tronco são dividas entre dois grupos entre células tronco embrionárias originadas do embrião e células tronco adulta,originadas em tecidos já desenvolvidos como placenta,cordão umbilical,polpa do dente, dentre outras.

Todas essas células possuem suas funções especificas como exemplo ás células tronco adultas tem como finalidade repara qualquer lesão ou dano causado ao tecido de origem,No entanto realçamos que alguns tecidos possuem poucas células tronco adultas,e precisam recrutar de outras fontes ,isso ocorre o processo da lesão o que aconteça é que essas células não correspondem prontamente ao dano deste tecido;Uma outra característica especial das células tronco é a sua auto - renovação,ou seja elas podem criar copias de si mesmas,garantindo uma reserva ás células com capacidade de reparo devido á essa característica muitas dessas células são utilizadas na aplicação terapêutica..

Além das células tronco serem dividas entre células tronco embrionárias e células tronco tronco adultas são dividas em um outro subgrupo,classificadas com base no seu potencial de diferenciação ou origem,sendo elas:

1. Totipotentes: são células-tronco que conseguem se diferenciar em todos os 216 tecidos que formam o corpo humano, inclusive placenta e anexos embrionários. É o caso de Zigoto (óvulo fertilizado); 
2. Pluripotentes: são as que conseguem se diferenciar nos tecidos provenientes dos 3 folhetos embrionários (ectoderme, endoderme e mesoderme). Ex. Células da Massa Interna de um Embrião de 5-6 dias;

3. Multipotentes: capazes de originar diversos tecidos;

4. Oligopotentes: capazes de originar poucos tecidos;

5. Unipotentes: capazes de se diferenciar em um único tecido.

Temos um grande mito quando se fala se existe alguma diferença entre células tronco e outra células ,como já citado a única diferença está na capacidade de elas se auto clonarem,como falei anteriormente, devido propriedades especiais das células-tronco como auto-renovação, ou seja, elas podem gerar cópias de si mesmas garantindo uma reserva de células com capacidade de reparo. Devido a essas características, as célulastronco são importantes principalmente na aplicação terapêutica de inúmeras doenças.

Em segundo lugar lugar, procuramos destacar a polemica que esse tipo de assunto traz,segundo a Prof ${ }^{a}$ Denise acredita que a ciência feita de maneira correta e pelo profissional serio visa sempre o bem estar e jamais a ciência poderá ser considerada antiética aquilo que procura o melhor para o cidadão.então,temos que a polemica é com relação aquilo que a ciência irá produzir,desenvolver se afetará questões sócias, éticas e principalmente $\mathrm{r}$ religiosa que é por onde a maior parte das pessoas buscam informação.Sendo assim, é importante ver que a religião é somente um meio de se obter informações e que ficar somente nela é um erro grave,devemos procurar maiores informações á fim de criar um conceito somente nosso.

Enfim,como você pode ter percebido células tronco não é tão complicado assim,como diz o titulo "Células Tronco-Informações á população",que você ter adquirido não somente informações,mas conhecimento e busque sempre mais.

Nota

1. Entrevista com a Professora Maria Denise Fernandes Carvalho,atualmente faz parte do corpo de docentes da faculdade Mackenzie,do Estado de São Paulo,na área de Ciências Biológicas e Saúde. 


\section{ARTIGO 6}

\section{O que você precisa saber sobre células-tronco}

por Pedro

Células-tronco. Ao tocar neste assunto se desencadeiam várias discussões, dentre elas críticas, manifestações positivas e negativas. Vários setores da sociedade são a favor e outros são contra. Porém, o maior problema não é a discussão entre os que são contra ou a favor, mas sim, é quando esse tema é discutido sem um mínimo de informação.

Por isso é importante que antes de criarmos uma opinião devemos antes pesquisar sobre o que é, de onde vem, por que são tão importantes e etc.. Mas pesquisar de verdade! Em fontes confiáveis e não somente em uma, para saber compreender as diversas formas com que o tema [células-tronco] é apresentado, entender a opinião dos demais grupos sociais e criar uma própria opinião que seja fortemente fundamentada.

\section{Pra começo de conversa...}

A pergunta que não quer calar: "o que são células-tronco?"

São células capazes de se transformarem em um ou todos os tecidos do corpo humano. Já que outras células só podem se transformar em tecidos específicos. Além de serem capazes de se auto-replicarem, ou seja, criar cópias idênticas de si mesmas

Por isso, elas são importantes no tratamento de doenças neurogenerativas como Alzheimer ou Parkinson ou causadas por deficiências celulares como leucemia e diabetes, pois elas fazem um "reparo" em células deficientes ou danificadas.

Segundo a Prof ${ }^{a}$. Dr. Maria Denise Fernandes Carvalho as células-tronco são divididas de acordo com a sua capacidade de originar outros tecidos:

“Totipotentes: são células-tronco que conseguem se diferenciar em todos os 216 tecidos que formam o corpo humano, inclusive placenta e anexos embrionários. É o caso do Zigoto (óvulo fertilizado);

Pluripotentes: são as que conseguem se diferenciar nos tecidos provenientes dos 3 folhetos embrionários (ectoderme, endoderme e mesoderme). Ex. Células da Massa Interna de um Embrião de 5-6 dias;

Multipotentes: capazes de originar diversos tecidos;

Oligopotentes: capazes de originar poucos tecidos;

Unipotentes: capazes de se diferenciar em um único tecido."

\section{Células-tronco embrionárias e células-tronco adultas}


Células -tronco embrionárias são o melhor exemplo de células-tronco totipotentes, pois são aquelas capazes de originar todo e qualquer tipo de tecido do corpo humano, sendo o embrião um ser humano no início de sua formação, não tendo ainda nenhum tecido específico, mas preparando-se para gerar os células que irão gerar os vários tecidos do corpo, as células-tronco adultasque já tem uma "programação" e por isso só podem se originarem tecidos específicos.

"As células-tronco embrionárias podem ser obtidas da massa interna de um embrião na fase de blastocisto (5-6 dias após a fertilização)", segundo a Prof ${ }^{a}$. Dr. M. D. F. Carvalho, sendo neste estágio quando o embrião tem por volta de 150 células.

Há três tipos de células-tronco adultas:

As hematopoiéticas ou células-tronco do sangue que formam o tecido sanguíneo; As células-troco endoteliais que formam o tecido vascular(artérias e veias; e

As células-troco mesenquimais: osso, cartilagem, músculo, gordura e fibroblastos.

\section{A grande polêmica}

Segundo a Prof ${ }^{\text {a }}$. Dr.M. D. F. Carvalho a polêmica gerada pelo assunto de células-tronco é uma consequência da falta de informação das pessoas. Pois quando as pessoas buscam informações concretas afim de ter um bom esclarecimento sobre o tem a polêmica desaparece.

"Infelizmente, muitas pessoas emitem opiniões aleatórias baseadas na falta de informação científica adequada”, diz ela.

Como por exemplo, as pessoas deconhecem da Lei 11.105 de Biossegurança que foi aprovada em 2005 que permite pesquisas com células-tronco embrionárias de embriões congelados há mais de 3 anos ou inviáveis, com o consentimento de seus genitores.

Outro motivo de polêmica também é desaprovação do uso de células-tronco embrionárias por diversos setores da sociedade, principalmente os religiosos, que alegam ser antiético o uso de células-tronco quando este destrói o embrião (lembrando que para esses diversos orgãos o embrião é um ser humano) ou o priva do direito de se desenvolver livremente.

Em vista dessa polêmica a Prof ${ }^{a}$. Dr.M. D. F. Carvalho alega que a polêmica ou até mesmoa aprovação do uso de células-tronco estará no objetivo e nas consequências do mesmo. "Acredito que qualquer coisa pode ser usada para o bem ou para o mal. Então, a partir daí qualquer tipo de interesse pode estar por trás da aprovação ou desaprovação do uso de células-tronco.” diz ela. 


\section{Ética e células-tronco embrionárias}

Como citado anteriomente pela Profa . Dr.M. D. F. Carvalho "qualquer coisa pode ser usada para o bem ou para o mal", para ela a ciência não pode ser considera antiética se visa o bem-estar do ser humano ou se visa melhorar a qualidade de vida de um cidadão.

\section{O que fazer para acabar com a polêmica?}

Como já dito antes, a polêmica é consequência da falta de informação. Que faz a maioria das pessoas levarem o assunto pelo lado mais fácil, que na maioria das vezes acaba sendo o religioso que se opõe a várias características do uso de células-tronco embrionárias, porém sem nenhuma informação. Isso pode e deve mudar! Como? Se cada um fizer a sua parte, pesquisando e transmitindo a informação correta à população, para que eles criem uma opinião com fundamentos concretos, até mesmo no meio religioso. A Prof ${ }^{a}$. Dr.M. D. F. Carvalho como cientista dá como exemplo a sua própria situação: "eu sou cientista e católica e procuro participar na minha igreja esclarecendo informações com experiências de dentro do laborátorio. Assim cada um deve fazer a sua parte levando as informações corretas aos leigos".

\section{As piores mentiras sobre células-tronco e que podem confundir as pessoas}

“células-tronco humanas oriundas de embriões congelados, quando se diferenciam para substituir as células lesadas num tecido degenerado, elas começam a expressar as proteínas responsáveis pela rejeição";

"total descontrole das células embrionárias surgindo diferenciações em tecidos distintos nas placas de cultura";

“300 à 400 mil embriões seriam sacrificados com o uso das células embrionárias";

“'feeder layers' seriam camadas de tecidos retiradas de fetos vivos";

"célula adulta age como embrionária".

\section{Mas será mentira mesmo?}

Realmente, só tem um jeito de saber!

Buscando, pesquisando a informação correta, só assim é que se pode acabar com a polêmica causada pela falta de informação e, com tantas opiniões equivocadas que são lançadas à população que infelizmente se acomoda e não corre atrás da verdadeira informação. 
Nota:

Este artigo foi escrito com base em entrevista feita com a Prof ${ }^{\text {a }}$. Dr. Maria Denise Fernandes de Carvalho, professora na Universidade Mackenzie, formada pela UFC (Universidade Federal do Ceará.

Entrevista realizada pelos alunos do Pré-Iniciação Cientifica da USP, Amanda Macedo Balduino, Edileusa Ferreira Pires, Haline Fernanda Abramo, José Teixeira dos Santos Filho, Sabrina Martins Caldas e Tatiane Andrade da Silva, FACULDADE DE EDUCAÇÃO. 


\section{ENTREVISTA}

\section{O que são células-tronco?}

2. Onde podem ser encontradas

3. Qual a sua importância?

Células-tronco são definidas como células imaturas ou indiferenciadas capazes de dar origem aos mais diversos tecidos do organismo como osso, cartilagem, nervos, músculos, etc. As Células-tronco embrionárias: são encontradas no embrião As Célulastronco adultas: são encontradas em tecidos que já se desenvolveram, como placenta, polpa de dente, cordão umbilical, medula óssea, gordura de lipoaspiração, dentre outros. Teoricamente as células-tronco adultas podem ser encontradas em qualquer tecido já desenvolvido, tanto adulto como fetal. A finalidade destas células seria de reparar qualquer lesão ou dano causado no tecido de origem. Assim, temos células-tronco adultas desde o fio de cabelo até a ponta do dedão do pé. No entanto, alguns tecidos possuem poucas células-tronco adultas e precisam recrutar de outras fontes quando ocorre um processo de lesão ou em outros casos alguns tecidos podem conter célulastronco adultas pouco ativas, como o caso do cérebro, as quais não respondem prontamente a uma lesão ou dano neste tecido.

Outra propriedade especial das células-tronco é a auto-renovação, ou seja, elas podem gerar cópias de si mesmas garantindo uma reserva de células com capacidade de reparo. Devido a essas características, as células-tronco são importantes principalmente na aplicação terapêutica.

\section{Só existe um tipo de células tronco?}

5. O que são células totipontentes?

6. Como se faz para obter uma célula totipotente?

As células-tronco podem ser classificadas com base no seu potencial de diferenciação ou na sua fonte de origem. Com base no seu potencial de diferenciação, temos:

1. Totipotentes: são células-tronco que conseguem se diferenciar em todos os 216 tecidos que formam o corpo humano, inclusive placenta e anexos embrionários. É o caso de Zigoto (óvulo fertilizado);

2. Pluripotentes: são as que conseguem se diferenciar nos tecidos provenientes dos 3 folhetos embrionários (ectoderme, endoderme e mesoderme). Ex. Células da Massa Interna de um Embrião de 5-6 dias; 
3. Multipotentes: capazes de originar diversos tecidos;

4. Oligopotentes: capazes de originar poucos tecidos;

5. Unipotentes: capazes de se diferenciar em um único tecido.

\section{Qual a diferença entre as células-tronco embrionárias e outra célula?}

As células-tronco embrionárias são as únicas capazes de originar tecidos provenientes dos 3 folhetos embrionários. Já as células-tronco adultas possuem um potencial de diferenciação mais limitado. Até hoje ainda não está claro na literatura se as célulastronco adultas são ou podem ser realmente pluripotentes e poucos estudos mostraram sua capacidade de diferenciação neurogênica. Assim as células-tronco embrionárias seriam as únicas capazes de tratar as doenças neurodegenerativas como a doença de Parkinson, Alzheimer alem de lesões na medula espinhal.

Em relação ao processo de extração, as células embrionárias podem ser obtidas da massa interna de um embrião na fase de blastocisto (5-6 dias após a fertilização). Neste estágio o embrião possui em torno de 150 células. Mais recentemente, células com propriedades semelhantes às células-tronco embrionárias foram obtidas a partir de células da pele de um indivíduo adulto. Essas células receberam o nome de iPS (induced pluripotent stem cell). No entanto, apesar de compartilharem muitas propriedades similares às células-tronco embrionárias, estas não são idênticas.

Em relação às células-tronco adultas existem diferentes tipos como as hematopoiéticas ou células-tronco do sangue, as células-tronco endoteliais e as células-tronco mesenquimais. Já é bem definido e estudado que as células-tronco hematopoiéticas formam o tecido sanguíneo, as endoteliais o sistema vascular (artérias e veias) e as mesenquimais: osso, cartilagem, músculo, gordura e fibroblastos.

\section{Por que há muita polêmica quando se trata de células- tronco?}

Acredito que a principal polêmica gerada vem da falta de informação. A partir do momento que a população busca esclarecimento a polêmica desaparece. A Lei 11.105 de Biossegurança que foi aprovada em 2005 Permite pesquisas com células-tronco embrionárias de embriões congelados há mais de 3 anos ou inviáveis, com consentimento dos genitores. Muita gente não sabe disso. 
9. Você acha que os indivíduos que se opõem a esse tipo de pesquisa em nome de uma pretensa defesa da integridade da vida, na verdade estão agindo contra o uso dessas pesquisas, impedindo assim que outras pessoas possam ser curadas?

Infelizmente, muitas pessoas emitem opiniões aleatórias baseadas na falta de informação científica adequada.

10. O que move as forças contra esse tipo de trabalho?São interesses políticos, religiosos ou que outro tipo?

11. A igreja é o único órgão que mostra ser contra ás ações práticas da ciência, com relação ao uso das células-tronco embrionárias?

Acredito que qualquer coisa pode ser usada para o bem ou para o mal. Então, a partir daí qualquer tipo de interesse pode estar por trás da aprovação ou desaprovação do uso das células tronco.

12. Apesar da grande discussão, qual será o beneficio das células-tronco para a população?

Como falei anteriormente, devido propriedades especiais das células-tronco como autorenovação, ou seja, elas podem gerar cópias de si mesmas garantindo uma reserva de células com capacidade de reparo. Devido a essas características, as células-tronco são importantes principalmente na aplicação terapêutica de inúmeras doenças, como já descrevemos.

13. O uso das células-tronco embrionárias é considerado ético para a ciência?Por que?

A ciência feita de maneira correta e pelo profissional sério visa sempre o bem-estar. Jamais a ciência poderá considerar antiético aquilo pode melhorar a qualidade de vida de um cidadão. Sempre foi assim na história da ciência correta.

14. Há alguma questão ética que não esteja ligada a igreja, sobre o uso de célulastronco embrionárias?

Acredito que as principais discordâncias originam-se da igreja.

15.Percebemos que na sociedade, muitas pessoas ouvem falar nesse assunto, mas não compreendem bem.Por esse motivo, acabam deixando levar pelo lado mais fácil, que 
muitas vezes é o lado religioso.O que a Senhora pensa sobre isso?Faltam informações?Há algum desinteresse por parte da população?Como isso pode mudar? Como já falei anteriormente a falta de informação gera muita confusão. Isso pode mudar se cada um fizer sua parte. Por exemplo, eu sou cientista e católica e procuro participar na minha igreja esclarecendo informações com experiências de dentro do laboratório. Assim cada um deve fazer sua parte levando às informações corretas aos leigos.

16.Quais as piores mentiras sobre células tronco que você já ouviu e que poderiam confundir as pessoas?

“células-tronco humanas oriundas de embriões congelados, quando se diferenciam para substituir as células lesadas num tecido degenerado, elas começam a expressar as proteínas responsáveis pela rejeição"

" total descontrole das células embrionárias surgindo diferenciações em tecidos distintos nas placas de cultura"

“ 300 a 400 mil embriões seriam sacrificados com o uso das células embrionárias" "feeder layers" seriam camadas de tecidos retiradas de fetos vivos"

" célula adulta age como embrionária" 


\section{ANEXO VII}

$5^{\mathrm{a}}$ fase de dados

Redação de um artigo de divulgação científica com temas escolhidos pelos próprios alunos* e questionário preenchido por eles para fins de avaliação de domínio e/ou apropriação de ferramenta

(julho de 2009)

(Os artigos foram reproduzidos de forma integral e os nomes dos alunos foram trocados para preservar sua identidade.)

*uma das alunas redigiu dois artigos

\section{ARTIGO 1}

\section{Nutrição: Obesidade Infantil}

por Soraia

Hoje em dia, o aumento da obesidade infantil é causado por vários fatores. As principais causas da obesidade infantil são certamente, o fato de as crianças comerem excessivamente e, ou não realizarem exercício físico regular ou terem, geralmente, hábitos sedentários.

Uma das principais causas da obesidade infantil são as calorias extras que não são queimadas através de exercícios ou de atividades físicas e que se transformam-se em gordura e quando esta gordura se torna excessiva, e isso cada vez mais, então a criança torna-se obesa.

Esta diferença causa obesidade infantil e será diferente de uma criança para outra, visto que pode ser suscitada por alguns fatores tais como os genes, questões de saúde e o sedentarismo, assim como as questões psicológicas que também contribuem para o aumento de peso e podem ser uma das causas da obesidade infantil.

Ainda que as principais causas da obesidade infantil sejam os transtornos subjacentes, o excesso de peso também está estreitamente relacionado com os estilos de vida. 


\section{Causas:}

\section{Hábitos alimentares e escolhas de alimentos deficientes:}

hoje em dia, a forma como preparamos os alimentos, e a falta de tempo diária, é totalmente diferente quando comparada com os nossos antepassados. com a ajuda de equipamentos modernos, o tempo e o esforço para a preparação dos alimentos simplificaram-se e tornou-se mais rápida. Esta é uma das razões pelas quais a restauração rápida domina as nossas dietas alimentares.

Ao estudar de que forma as crianças comem hoje em dia, descobrirá qual as principais causas da obesidade infantil. Pequenas mudanças na sua dieta diária poderá ajudá-lo(a) amplamente a prevenir o excesso de peso. As escolhas mais saudáveis em termos de alimentos incluem os vegetais e a fruta em detrimento dos "snacks" açucarados. As opções mais populares incluem cenouras e bananas, aipo, maçãs e até saladas que incluem uma grande variedade de vegetais.

Ajudar as crianças a perceberem e a fazerem as melhores escolhas alimentares durante a infância garantirá, seguramente, que façam as escolhas corretas na idade adulta. Um mau comportamento também é uma das causas da obesidade infantil.Este grupo de crianças come alimentos com baixo valor nutritivo e alto teor de gordura.

Também têm o hábito de comer em excesso e, muitas vezes, os alimentos que consomem têm muito poucas calorias,ou seja, os alimentos que consomem não são suficientemente nutritivos para as suas necessidades.

\section{Falta de exercício físico}

A falta de exercício físico é também uma das causas da obesidade infantil. As crianças que passam muito tempo a ver televisão terão mais chance de se tornarem crianças obesas do que as crianças que brincam ao ar livre ou que fazem exercícios físicos.

Os exercícios físicos que as crianças gostam de praticar hoje em dia inclui ver televisão, jogar no computador, surfar na Internet, conversar em salas de "Chat" e qualquer jogo que escolham exercita somente a sua mente, a sua cabeça e as mãos. Se combinar as péssimas escolhas alimentares com a falta de exercício físico, deparar-se-á com uma elevada possibilidade de causar a obesidade infantil. 


\section{Fator genético}

verificou-se que a genética e o ADN são fatores que contribuem para as causas da obesidade infantil. Infelizmente, algumas crianças estão naturalmente predispostas à obesidade. Estas crianças nasceram com genes que fazem com que engordem mais rapidamente do que as outras crianças.

Se assim for, pode facilmente ser um problema genético. As estatísticas mostram que, se um dos seus pais tinha excesso de peso ou era obeso, são cerca de 3 vezes a probabilidade de estar na mesma situação.

\section{Stress e questões psicológicas:}

Algumas crianças têm dificuldades em lidar com o stress pelo que recorrem à comida como forma de sentirem algum reconforto quando se sentem stressadas, e muitas crianças têm tendência a comer para responder a emoções negativas, como estar aborrecido(a), sentir-se ansioso(a) ou estar zangado(a).

Todas as crianças têm de lidar com diversos fatores nas suas vidas. As causas da obesidade também podem ser vistas como uma fragilidade, uma falta de vontade ou uma escolha de um determinado estilo de vida quanto ao comer em excesso e não praticar exercício suficiente.

\section{Um dos métodos para se classificar uma criança em sobrepeso e obesa}

Existem vários métodos para diagnosticar e classificar a criança em obesa ou com sobrepeso. Em geral, utiliza-se o Índice de Massa Corporal (IMC). Este é calculado pela seguinte fórmula:

$$
I M C=\frac{\operatorname{peso}(K g)}{\operatorname{altura}(m)^{2}}
$$

O resultado obtido deve ser comparado com valores de referência específicos para idade e sexo. Os valores do IMC acima dos quais a criança e o adolescente podem ser considerados com sobrepeso ou obesidade estão na tabela a seguir:

\begin{tabular}{|c|c|c|c|c|}
\hline \multicolumn{5}{|c|}{ Diagnóstico da obesidade em crianças acima de 10 anos pelo IMC } \\
\hline Idade/anos & \multicolumn{2}{|c|}{ sobrepeso } & \multicolumn{2}{c|}{ obesidade } \\
\hline & masculino & feminino & masculino & feminino \\
\hline & & & & \\
\hline 10 & 20 & 20 & 23 & 23 \\
\hline 11 & 20 & 21 & 24 & 23 \\
\hline 12 & 21 & 22 & 25 & 26 \\
\hline
\end{tabular}




\begin{tabular}{|l|l|l|l|l|}
\hline 13 & 22 & 23 & 26 & 27 \\
\hline 14 & 23 & 24 & 27 & 28 \\
\hline 15 & 24 & 24 & 28 & 29 \\
\hline 16 & 24 & 25 & 29 & 29 \\
\hline 17 & 25 & 25 & 29 & 30 \\
\hline 18 & 26 & 26 & 30 & 30 \\
\hline
\end{tabular}

A orientação dietética é fundamental para determinar a perda de peso controlada ou a manutenção do mesmo, para não prejudicar o crescimento. Em resumo, as modificações de comportamento devem ser adotadas por toda a família e as seguintes dicas são importantes:

- Estimular aleitamento materno e limitar a introdução de alimentos sólidos precocemente;

- Estabelecer horários para as refeições e lanches: intervalo mínimo de uma hora e meia e máximo de três horas;

- Encorajar a autonomia das crianças e adolescentes no controle da sua ingestão alimentar;

- Diminuir o tamanho das porções e não insistir que a criança raspe o prato.

- Evitar a sobremesa;

- Não saciar a sede com chás, sucos ou refrigerantes, estimular beber água;

- Não ter em casa alimentos que façam a criança sair do manejo;

- Não usar adoçantes de forma indiscriminada;

- Mudar o hábito familiar de comemorar situações comendo;

- $\quad$ Não comer assistindo televisão;

- Limitar o tempo de assistir televisão por 2 horas por dia;

- Estimular rotineiramente as atividades físicas, incluindo jogos não-estruturados em casa, na escola e na comunidade;

- Pais devem participar e dar exemplo.

A obesidade infanto-juvenil é um sério agravo para a saúde e prevenir significa diminuir, de uma forma racional, a incidência de doenças crônico-degenerativas na vida futura. 


\section{ARTIGO 2}

\section{Gripe Suína: As verdades e os mitos da doença}

por Simone

A gripe suína ( Influenza A H1 N1) é a doença mais temida do momento. Ela se destaca não pela sua "capacidade" de morte entre as pessoas, mas sim pelo seu fácil contágio.

A cada dia vemos na TV, novos casos de pessoas que foram infectadas pela doença, o que gera pânico entre a população, que tem medo de serem as próximas vítimas da doença.

No entanto, é importante conhecer bem os aspectos dessa nova doença, para não correr o risco de se contaminar e para evitar um pânico maior entre as pessoas.

A gripe suína, ao contrário do que muitos pensam, não transmitida através do consumo de carne suína e sim pelo contato com pessoas que foram infectadas pelo vírus da doença, e por vias aéreas, assim como a gripe comum.

Os primeiros casos da doença começaram a surgir em abril de 2009, tendo Estados Unidos, Argentina e México como países em que mais há registros de pessoas contaminadas e mais casos de morte pela doença. Em todo o mundo há um total de quase 100 mil infectados e quase 500 mortes, segundo dados da Organização Mundial de Saúde.

Desde que começaram a surgir os primeiros casos da doença, esta não parou mais de crescer.

No Brasil o primeiro caso da doença foi detectado em maio de 2009, no estado do Rio de Janeiro e seu primeiro caso de morte foi no final de junho, no Rio Grande do Sul. A vítima era um caminhoneiro que havia feito uma viagem de sete dias para a Argentina. Atualmente já são quatro, o número de mortes por gripe suína no nosso país, entre eles um caso espantoso de uma menina de 11 anos de idade, que morava na região de Osasco.O que intriga no caso dessa menina, é o fato de que nem ela, nem ninguém da família viajou para fora do país, o que gera polêmica pois, não se sabe de onde a menina teria contraído o vírus da doença.

Com tudo isso, pesquisadores e cientistas tentam encontrar uma forma de controlar a ação do vírus H1 N1 e até mesmo criar uma vacina que possa prevenir as pessoas de um possível contágio. 
Pesquisadores brasileiros anunciaram no dia 16 de junho de 2009, que haviam conseguido isolar o novo vírus. Segundo eles o vírus é diferente do que havia sido isolado na Califórnia e apresenta uma grande capacidade de mutação.

As chances de se criar uma vacina para o combate da doença, são grandes, mas ainda são necessárias várias pesquisas em torno do vírus.

Como todos nós sabemos, a doença é altamente contagiosa e não há nada melhor do que prevení-la ou no mínino tentar evitá-la (se é que isso é possível).

É importante observar os sintomas da doença que em geral são febre alta e repentina, dores fortes de cabeça, dores musculares, fadiga, tosse entre outros. É perceptível a semelhança desses sintomas com o da gripe comum, entre tanto os médicos observam que o que os diferenciam em partes é a presença da febre muito alta.

Enfim, a gripe suína não pára de crescer, portanto o melhor a se fazer no momento é nos prevenirmos e estarmos atentos aos sintomas, torcendo para que os cientistas descubram o mais rápido possível uma vacina eficaz contra esse vírus tão contagioso. 


\section{ARTIGO 3}

\section{Alimentos transgênicos: Benefícios ou malefícios?}

por Simone

Com certeza, certamente, você já deve ter ouvido falar nos alimentos transgênicos. Alguns são a favor, outros são contra, mas, afinal quem tem a razão?

Essa pergunta se torna difícil uma vez que muito se ouve falar, mas que na prática a população não sabe direito o que realmente eles são.

Para começar a se ter uma idéia do que sejam os alimentos transgênicos, é importante ter primeiro uma idéia do que são os chamados OGM's (organismos geneticamente modificados).

Os organismos geneticamente modificados são organismos que através da engenharia genética recebem genes de outros organismos.

A finalidade de tais organismos modificados geneticamente, é a de transformá-los em organismos de melhor qualidade, ou seja, torná-los melhor do que os que a própria natureza seria capaz de produzir.

No caso dos alimentos transgênicos eles são chamados dessa forma por terem recebido em laboratório, um ou mais genes de diferentes organismos. Com isso, esses alimentos tornam-se, em sua maioria, mais resistentes a pragas e a inseticidas.

A produção de tais alimentos está presente em países como Estados Unidos, Argentina, China Canadá, Portugal, Brasil, Índia entre outros. Só na Europa é permitido o cultivo de mais de 17 espécies de transgênicos.

No Brasil, há o cultivo e comercialização de soja geneticamente modificada.

Para os produtores de alimentos geneticamente modificados, o cultivo de tais alimentos

é favorável, porque seria capaz de diminuir a fome mundial, uma vez que a produtividade de tais alimentos aumentaria. Entretanto, se discute o fato de que não é a falta de alimento que causa a fome, mas sim a distribuição irregular entre as pessoas.

O que também gera discussão é o fato de que alguns acreditam que o cultivo de tais alimentos podem causar sérios danos ao meio ambiente. Entre eles é discutida a chamada polinização cruzada entre os alimentos transgênicos e os alimentos produzidos pela natureza, que podem realmente trazer danos aos chamados alimentos naturais.

Entre outras questões levantadas, há a de que tais alimentos podem causar danos à saúde humana e animal, levando quem os consome a um possível quadro alérgico. 
As pesquisas com esse tipo de alimento não param, entretanto ficam em menos evidência, o que é um erro, pois a sociedade merece saber o que realmente estão consumindo e quais os benefícios ou malefícios estes alimentos podem causar.

É importante ficarmos atentos aos alimentos transgênicos que consumimos. Há uma lei que obriga os produtores a colocarem no rótulo do produto uma indicação de que estes são transgênicos. Portanto é sempre bom ver o que se consome e ver se julgamos como um bem ou um mal a todos. 


\section{ARTIGO 4}

\section{Aquecimento global e repercussões na saúde}

por Carla

Há mais de 50 anos têm sido relatados os efeitos da poluição do ar na saúde. São bastante conhecidos os episódios decorrentes da elevação aguda na concentração de poluentes ocorridos no Vale do Meuse (Bélgica, 1930), em Donora (Pensilvânia, 1948) e em Londres, 1952, responsáveis por milhares de internações e óbitos por doenças respiratórias e cardiovasculares. Estes fatos chamaram a atenção do mundo, estimularam a realização de milhares de estudos e induziram os países a adotarem leis ambientais cada vez mais projetivas, mas ainda insuficientes.

Os estudos epidemiológicos e experimentais realizados têm comprovado, de maneira consistente, que a poluição do ar aumenta o risco de doenças e de mortalidade por doenças cardiovasculares, respiratórias e por câncer de pulmão ${ }^{1-2}$.

Nosso organismo desenvolveu, ao longo de um processo de evolução de milhões de anos, um sofisticado e eficiente mecanismo de defesa contra as doenças infecciosas e outras agressões do meio, possibilitando que chegássemos até quase meados do século passado sem o uso de antibióticos, vacinas e outros medicamentos e procedimentos. É claro, porém, que tal processo deu-se à custa de elevada mortalidade, que foi responsável pela seleção da espécie. Entretanto, não desenvolvemos mecanismos para nos defender dos efeitos gerados a partir da Revolução Industrial (gases, poeiras e radiações), processo recente (250 anos) na evolução da espécie. Nosso organismo reage a estas agressões freqüentemente de maneira parecida a como faz com relação às infecções, muitas vezes levando à lesões em vez da cura.

Ao lado dos efeitos diretos na saúde humana, cientistas têm procurado chamar a atenção para os efeitos dos poluentes no meio ambiente e da degradação ambiental, como a redução das áreas verdes provocada pela atividade humana. Mas as previsões e estudos eram considerados por muitos como catastrofistas, havendo grande resistência por parte dos países mais poluidores a enfrentar o problema apontado.

A recente divulgação do relatório do Painel Intergovernamental sobre Mudança Climática (IPCC) ${ }^{3}$, constituído em 1988 pela Organização Meteorológica Mundial (WMO) e pelo Programa Ambiental das Nações Unidas (UNEP), órgãos vinculados à ONU, conseguiu chamar a atenção de governantes e de grande parte da população para 
as conseqüências danosas da ação do homem ao meio ambiente. Mesmo os Estados Unidos da América do Norte, que vêm se recusando a assinar o Protocolo de Kyoto, não puderam ficar alheios e contestar as conclusões.

O relatório divulgado em Paris demonstrou de maneira consistente que as alterações na atmosfera com o aumento da concentração dos gases de efeito estufa (que sempre existiram e ajudam a manter a temperatura da terra estável e não muito fria, pois absorvem parte da radiação solar) e o aumento da radiação solar (decorrente da redução da camada de ozônio na estratosfera, provocada pela emissão de clorofluorcabonos (CFCs) que, sob ação da luz ultravioleta do sol, libera cloro que reage e elimina o ozônio) são responsáveis pelo ritmo do aquecimento global observado.

As previsões apontam que até o final deste século a temperatura da Terra poderá aumentar em até quatro graus, com repercussões globais como as decorrentes da elevação média do nível do mar em até $60 \mathrm{~cm}$, devido ao derretimento do gelo das calotas polares, caso os níveis de emissão de gases não sejam drasticamente reduzidos. O Relatório apresenta também dados sobre a concentração de gases de efeito estufa nos últimos dez mil anos, demonstrando que seu aumento relevante teve início a partir de 1750, com importante incremento nos últimos 50 anos. A concentração de dióxido de carbono $\left(\mathrm{CO}_{2}\right)$, o mais importante dos gases de efeito estufa gerado pela atividade do homem (outros são o metano, óxidos nitrosos, ozônio) passou de 280 ppm (partes por milhão), na era pré-industrial, para 379 ppm, em 2005, com aumento exponencial nas últimas décadas. A taxa de crescimento de $\mathrm{CO}_{2}$ nos últimos dez anos (1995-2005) foi de 1,9 ppm/ano, contra 1,4 ppm/ano no período de 1960-2005. Elevação semelhante foi observada para os óxidos nitrosos e o metano, todos relacionados à queima de combustíveis fósseis (derivados do petróleo, carvão) e de biomassa (queimadas de canade-açúcar e de florestas).

Os dados comprovam também que com o aumento das concentrações dos gases de efeito estufa (assim chamados por absorverem radiação solar e aumentarem o aquecimento na superfície da Terra - a troposfera), verifica-se um correspondente e concomitante aumento da temperatura, da velocidade de derretimento das geleiras polares e da elevação do nível do mar.

Ao mesmo tempo em que este processo ocorre, a eliminação de áreas verdes e a redução de fito plâncton nos oceanos pela ação da radiação ultravioleta que atinge a superfície da Terra em maior quantidade devido à redução da camada de ozônio, reduzem a 
capacidade de extração de $\mathrm{CO}_{2}$, contribuindo assim para favorecer ainda mais o aquecimento.

Em síntese, a ação do homem tem levado à poluição do ar; destruído a camada de ozônio da estratosfera, que desempenha a função de reduzir a quantidade de radiação solar que atinge a superfície da Terra (troposfera); provocado o aumento das concentrações de gases de efeito estufa $\left(\mathrm{CO}_{2}, \mathrm{O}_{3}\right.$, metano, NOx) na troposfera, absorvendo maior quantidade de radiação solar e retendo calor; e tem reduzido a capacidade de captação de $\mathrm{CO}_{2}$ pela eliminação de áreas verdes e degradação da flora dos oceanos, levando assim às alterações climáticas como o aquecendo global, alterações pluviométricas, secas, aumentado a frequiência de catástrofes, além dos efeitos diretos na saúde. Estimativas ${ }^{4}$ atuais atribuem cerca de 800 mil óbitos à poluição do ar ambiental, 1,6 milhões à poluição do ar no interior dos domicílios e 154 mil óbitos às alterações climáticas; são cerca de 2,5 milhões de mortes evitáveis a cada ano e que, ao se manter os níveis atuais de emissões e destruição da natureza, tendem a aumentar.

O Brasil, embora não esteja entre os principais poluidores e emissores de gases de efeito estufa também precisam tomar medidas drásticas que contribuam para reduzir a degradação do meio ambiente. Ampliar a rede de transportes coletivos, sobretudos nas regiões metropolitanas, desestimulando as emissões veiculares, eliminarem as injustificadas queimadas de cana-de-açúcar e de florestas, fruto da ganância e da busca do lucro fácil, e ampliar o já bem-sucedido esforço no desenvolvimento e uso de fontes não poluentes ou menos poluentes, como o biodiesel e álcool, são medidas possíveis de ser implantado a curto prazo e, assim, contribuir para a preservação da saúde e da vida em nosso Planeta. 


\section{ARTIGO 5}

\section{Gripe Suína: Um desafio?}

por Mônica

O mundo em que vivemos está sempre em constante mudança e transformação. $\mathrm{O}$ tempo passa, as tecnologias avançam, curas e doenças vão surgindo... $\mathrm{O}$ homem precisa está preparado para isso. O que acontece muitas vezes é que essas informações chegam de supetão, assustando qualquer um. É o caso da nova gripe, a gripe suína que tem deixado muita gente de cabelo em pé!

A OMS (Organização Mundial de Saúde) declarou a gripe suína como ameaça de nível 6, o que indica uma pandemia. Numa epidemia o número de casos de uma determinada doença aumenta mais do que aquilo que é considerado habitual. Pandemia é uma epidemia que atinge uma área geográfica muito grande, em geral toda a Terra.

A gripe suína, também conhecida como " gripe Porcina”, trata-se do vírus Influenza A H1N1, sendo que o vírus Influenza A é muito transmissível e mutável, é um subtipo do vírus da gripe comum. "H" refere-se a proteína hemaglutina e "n" a proteína Neuraminidase .Esta doença é adquirida através de uma infecção viral que atinge o sistema respiratório.

O contágio se dá através do contato com porcos infectados ou ambientes onde os porcos poderiam está presentes. Contudo, alguns casos humanos não envolviam este contato, mostrando a transmissão direta entre seres humanos.

Vale ressaltar, que mesmo recebendo o nome de "gripe suína", não há nenhum tipo de transmissão pela carne do porco, até porque antes de ser consumida passa por processos de higienização, como o cozimento a $70{ }^{\circ} \mathrm{C}$.

O primeiro caso de gripe suína surgiu na cidade de La Gloria, estado de Vera Cruz no México, em meados de fevereiro. O México tornou-se o lugar onde a doença estava mais disseminada e focalizada, entretanto começou a se expandir para lugares como E.U. A, Áustria, Canadá, China , Dinamarca, França, Alemanha, Israel, Chile, Holanda Nova Zelândia, Coréia do Sul, Espanha, Suíça, Reino Unido, Brasil, Argentina entre outros.No total somam 73 países.

Como qualquer outra gripe, esta também pode matar, embora a taxa de mortalidade tenha sido bem baixa e as chances remotas, cera de $1,2 \%$,número que tende a cair. Ela possui cura, há remédios antivirais para gripe sazonal (Influenza Sazonal) que se 
mostram eficientes, como o medicamento Oseltamivir. Ainda não há vacina preventiva. Os sintomas não são muito diferentes da gripe comum, basicamente são dores musculares, dor de garganta, coriza, febre alta e tosse sem secreção, algumas pessoas também podem apresentar vômito e disenteria. Ao apresentar esses sintomas é importante ficar em casa de repouso, afastado do trabalho, escola ou qualquer lugar público.Tomar muito líquido e procurar um médico, nunca ingerir medicamentos sem prescrição.

Medidas de prevenção podem e devem ser tomadas, como higienizar as mãos; evitar tocar os olhos, nariz ou boca após contato com superfícies; ao tossir ou espirrar proteger com lenços a boca e o nariz( descartáveis se possível); evitar contato com pessoas infectadas, caso não possa evitar esse contato, é correto usar máscaras cirúrgicas; manter ambientes com boa circulação de ar e cuidar bem da saúde.

Ao viajar também é importante manter essas medidas, e procurar evitar o contato com pessoas que apresentem os sintomas.

O tempo de incubação varia de 24 h a 3 dias. As pessoas que apresentam doenças crônicas ou deficiências imunológicas, sempre estão mais propícias.

No Brasil já foram confirmados mais de 900 casos, sendo que o estado de São Paulo compreende a maioria. $\mathrm{O}$ vírus Influenza A dissemina-se pela Terra, a ciência trabalha para contê-lo e controlá-lo, afinal é um novo desafio para a humanidade.

\section{Para divertir...}



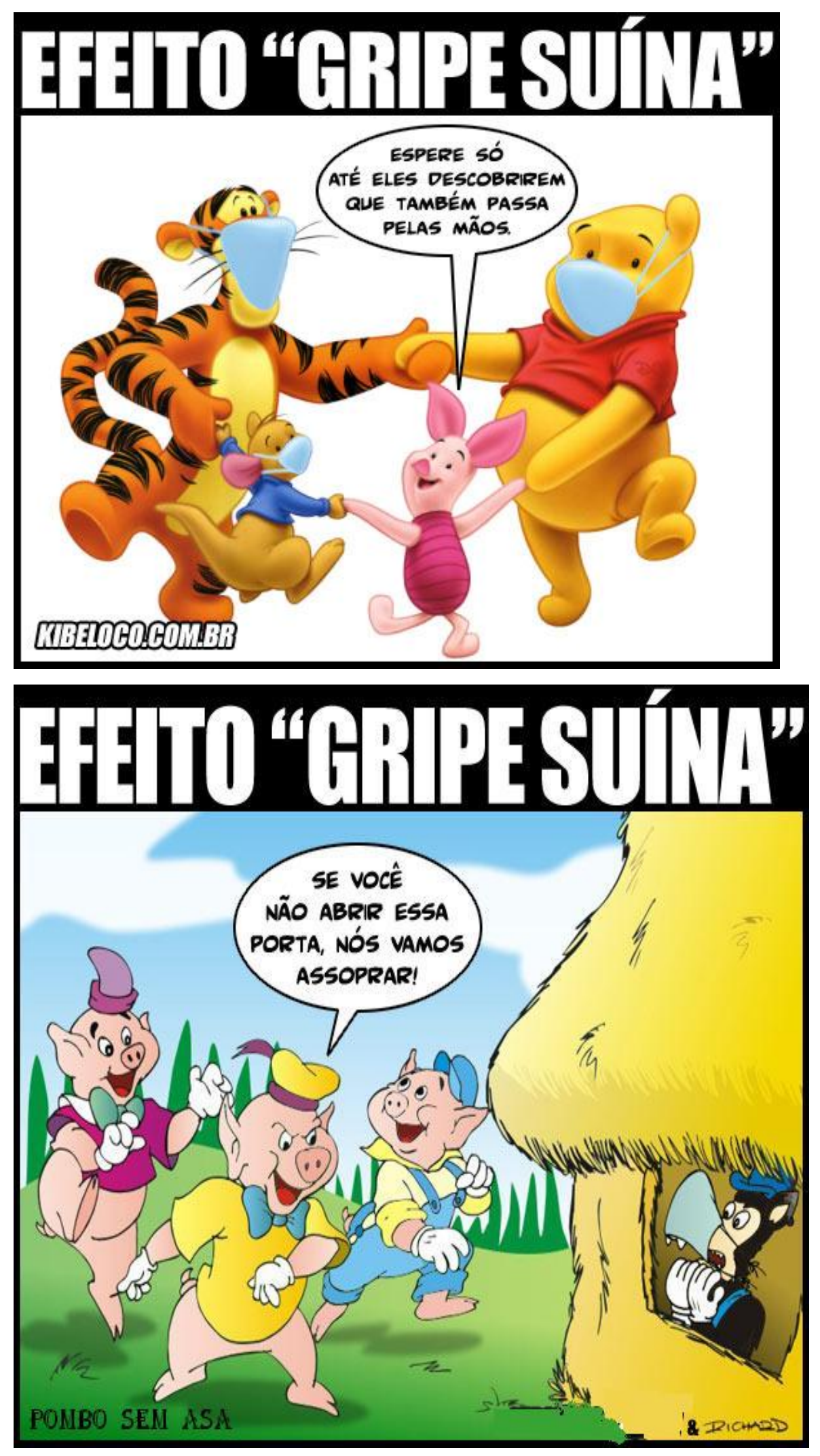


\section{ARTIGO 6}

\section{A $1^{\text {a }}$ pandemia do $3^{\circ}$ milênio}

por Andressa

Muito parecida com a gripe comum, porém prima próxima de varias outras gripes que já assombraram tanto esse mundo, tais como a gripe espanhola, a gripe russa e tantas outras, a gripe suína ou no seu nome cientifico influenza A (H1N1) após ter seus primeiros casos no mês de março no México, virou pandemia no dia 25 de Abril de 2009.

Após o paciente zero, Édgar Hernández de apenas quatro anos, a gripe suína se espalhou rapidamente pelo globo terrestre e já contaminou cerca de 174.159 e já matou pessoas nos quatro cantos do mundo.

A gripe suína passou a se chamar influenza A (H1N1) por vários motivos, um deles era o sacrifício e/ou a despensa de porcos por causa do vírus. Este vírus é uma mutação que uniu a influenza humana, a aviaria e a suína. O nome $\mathrm{H} 1 \mathrm{~N} 1$ refere-se as proteínas existentes no vírus: $\mathrm{H}$ refere-se à proteína hemaglutinina e a letra $\mathrm{N}$ à proteína neuraminidase.

Tanto a mortalidade quanto os sintomas são muito parecidos com o da gripe normal, porém com o aparecimento repentino de febre, $\underline{\text { tosse, }} \underline{\text { dor de cabeça intensa, dores }}$

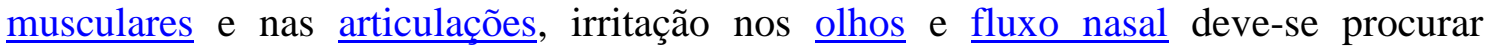
rapidamente um posto médico para a confirmação da gripe.

Enfim, essa nova pandemia tomou conta do mundo todo e não ira parar se alguns cuidados básicos não forem tomados, tais como: Cubra seu nariz e boca com um lenço quando tossir ou espirrar. Jogue no lixo o lenço após o uso; lave suas mãos constantemente com água e sabão, especialmente depois de tossir ou espirrar. Produtos à base de álcool para limpar as mãos também são efetivos; evite tocar seus olhos, nariz ou boca. Os germes se espalham deste modo; evite contato próximo com pessoas doentes; se você ficar doente, fique em casa e limite o contato com outros, para evitar infectá-los. 


\section{ARTIGO 7}

\section{Amazônia, por que ela é importante para nós?}

por Pedro

"Quando a última árvore for cortada, o último pássaro morrer e a última gota de água for bebida, o homem vai descobrir que dinheiro não se come"

Green Peace

Você já deve ter ouvido alguma vez, seja em revista, jornal, internet, televisão, enfim nos vários meios de comunicação, falarem alguma coisa relacionada a Amazônia, não? Seja sobre desmatamento, pela preservação, pela diversidade de fauna e flora da região, mais e mais vem se falando na sociedade sobre a Amazônia. Mas, por quê? O que a Amazônia tem a nos oferecer?

\section{Voltando no tempo...}

Amazônia: A maior região brasileira que possui uma variedade de recursos naturais, uma diversidade de animais e plantas que até hoje é desconhecida entre biológos e botânicos e outros estudiosos. Foi descoberta antes de Cabral avistar o Monte Pascoal, por Vicente Pinzón, navegador espanhol, em 1498. Porém só começou a ser colonizada em 1630 pelos portugueses.

Além da exploração do latex (substância extraída da seringeuira, utilizada na produção de borracha), do desmatamento e vários outros fatores é relevante dizer que a construção de estradas, rodovias como a BR-163, que liga Cuiabá, no Mato Grosso à Santarém, no Pará, construída em 1930 propiciou a vinda de muitas pessoas deslumbradas com a possibilidade de enriquecer com a exploração dos recursos da amazônia, nisso, os vilarejos ao invés se se tornarem centros de preservação ambiental, tornara-se verdadeiras centros de "destruição ambiental", já que as pessoas iam para lá para explorar e não preservar.

\section{Preservação da Amazônia: Será só uma questão ambietalista?}

A Amazônia é rica numa vasta diversidade biológica, nela encontramos a maior bacia hidrográfica, o maior território coberto por floresta, uma grande reserva de carbono, o maior rio, grandes reservas de minérios, pescado e madeira e, maior banco genético e etc. E nisso a importância da Amazônia já engloba vários assuntos como florestas e animais em extinção pela ação do homem, a questão da água que se concentra em grande parte na ragião amazônica, da economia, pois a exploração dos recursos da 
Amazônia gera um grande fluxo de capital, capital esse que vem pricipalmente do desmatamento que é um dos vários fatores que influenciam no efeito estufa, pois as árvores absorvem o gás carbônico da atmosfera, sendo o gás carbônico o pricipal causador do Aquecimento Global.

Porém, a questão da importância da Amazônia não é só uma questão "ambientalista", estudos feitos pelo casal pesquisador Gerard e Margi Moss revelam que a evaporação das águas dos rios, a traspiração das árvores são responsáveis por parte das chuvas em grande parte do país e nos países à leste da região.

As regiões brasileiras e algumas vizinhas ao Brasil como Bolivia, Paraguai e o norte da Argentina estão na mesma faixa de paralelos (linhas horizontais retas que indicam a latitude) que os maiores desertos do mundo, no Chile, na África e na Austrália. E para Gerard esse fato pode ter relação com a circulação do ar, carregado de vapor d'água proveniente da evaporação dos rios e da transpiração das árvores da Amazônia.

A essa descoberta foi dado o termo "rios voadores". As águas dos rios voadores chegam a abrager o Sul, Sudeste e Centro-Oeste brasileiro e os países vizinhos até a Cordilheira dos Andes

Além de ser responsável por parte da chuvas em volta, a Floresta Amazônica ajuda amenizar o aquecimento do ar, já que os raios solares que incidem na região são utlizados na fotossíntese das árvores e na evaporação das águas.

\section{Palavras Finais}

Geraldo Mendes dos Santos, pesquisador do Inpa(Instituto Nacional de Pesquisas da Amazônia), ao ser questionado por um colega cientista sobre a importância da Amazônia para o mundo, fala sobre uma definição de Amazônia, com uma única palavra, com base no que a Amazônia representa para a sociedade:

"Recorro aos conhecimentos adquiridos, dou asas à imaginação, reflito profundamente, apelo para o senso linguístico e estético de que disponho e uma palavra me aparece, que julgo a mais satisfatória para sintetizar a essência amazônica: Poema.

Eis, então, a frase proposta: A Amazônia é um poema. Caso fosse necessário complementar a frase, talvez para atender de modo mais apropriado ao formulador da pergunta, ela ficaria assim formulada:A importância da Amazônia se confunde com a própria importância do mundo em que vivemos; assim, mais que um ecossistema, região ou bioma, mais que a porção mais verdejante do planeta, a Amazônia é um poema, um santuário da vida, uma expressão do ato criativo, a manifestação divina na 
terra."

\section{Referências:}

GUIA DO ESTUDANTE - Atualidades Vestibular + ENEM, $1^{\circ}$ semestre de 2009.

Editora Abril. pp.88-93.

\section{Amazônia viva: prioridade global}

http://www.greenpeace.org/brasil/amazonia/amaz-nia-viva-prioridade-glob

retirado dia 24/08/2009 às $20 \mathrm{~h} 24$

Qual a importância da Amazônia para o mundo?, texto de Geraldo Mendes dos Santos

http://www.jornaldaciencia.org.br/Detalhe.jsp?id=24790

retirado dia 24/08/2009 às $15 \mathrm{~h} 48$

Rios Voadores: projeto avalia a importância da Amazônia para a manutenção da chuva

http://www.amazonia.org.br/noticias/noticia.cfm?id=268119

retirado dia 24/08/2009 às $18 \mathrm{~h} 59$

Rios Voadores revelam importância da Amazônia

http://planetasustentavel.abril.com.br/noticia/ambiente/conteudo_429796.shtml retirado dia 23/09/2009 às $22 \mathrm{~h} 34$

\section{Notas:}

Visite o site:www.riosvoadores.com.br

No ENEM 2008, A PROPOSTA DE REDAÇÃO fazia uma pequena abordagem sobre a influência da Amazônia nas chuvas brasileiras. Vale a pena dar uma conferida: http://gabarito.enem.inep.gov.br/enem2008/PROVA_ENEM_2008_FINAL_AMAREL A.pdf 


\section{Questionário respondido pela Carla}

\section{O que mais atraiu você em relação ao tema escolhido? Por quê?}

Primeiro foi à grande polêmica que o assunto traz em si, por que temos que ter grande preocupação com aquilo que estamos fazendo com o nosso planeta,cuidados simples que muitas das vezes refletem na nossa saúde.

\section{Como você se sente escrevendo um artigo de divulgação?}

Sinto-me honrada, pois tinha outra visão do que era escrever um artigo de divulgação e nunca me vi escrevendo algo desse tipo, mas valeu a experiência.

3. Você acha que dominou as ferramentas para montar artigos de divulgação científica? De que forma as incorporou?

$\mathrm{Na}$ realidade não acredito ter dominado totalmente, mas aprendi muita coisa como a montagem do texto, tipo de linguagem a ser utilizada e ECT. Procurou incorporar esses requisitos lendo outros artigos de divulgação de diversos temas.

\section{Cite os passos básicos que você usou para montar seu artigo.}

Primeira escolha do tema, pesquisa sobre o assunto relacionado,tipo de linguagem a ser escrito,procurar a melhor forma de expressar o tema á fim de que todos entendem, e estrutura.

5. Hoje você saberia mostrar a diferença entre um artigo científico e um artigo de divulgação? Aponte alguns exemplos.

Sim como, por exemplo, a linguagem de artigo cientifico e bem diferente de um artigo de divulgação, nele é onde há citações do assunto,o autor visa fazer com o tema seja mais concentrado em palavras do tipo formação do DNA é essa, e assim por diante.

\section{Para você, então, o que é divulgação científica?}

A divulgação científica é como uma forma de falar e escrever dos assuntos relacionados a ciência de uma forma simples e fácil á fim de que as pessoas que apesar que talvez nunca tenham ouvido falar do assunto ou talvez sabiam pouco possam compreender melhor e realmente saber o que ele é.

\section{Se tivesse que passar o que aprendeu adiante, como você o faria?}

Bem como disse anteriormente procuraria elaborar a melhor forma de mostrar as outras pessoas como tratar de temas da ciência de uma forma simples e fácil e que não é tão chato assim, procuraria passar tudo isso através de textos,fotos,pesquisas e tudo que eu poderei utilizar...

8. Você se acha capaz de comandar um pequeno grupo em um trabalho de divulgação científica? Por quê? 
Talvez sim e não,isto por que primeiro é com que eu domine totalmente o que divulgação cientifica e sim por que existem outros recurso que me ajudam em muita a saber como se faz uma divulgação cientifica.

9. O que mais gostou e o que menos gostou na hora de redigir seu artigo?

O que mais gostei foi a forma de redigir o artigo e não gostei um pouco dos pequenos detalhes que um artigo deve ter por que acabei esquecendo deles.

10. Como você se classificaria hoje depois de redigir alguns artigos? Explique como se sentiu na primeira vez e como se sente hoje.

Classificarei como bom, por que não me aprimorei totalmente na hora de escrever os artigos apesar dos diversos temas. Há primeira vez foi horrível, pensei que era um bicho de sete cabeças, mas pedi ajuda á um professor que também trabalha nessa mesma linha o que me ajudou bastante, hoje eu me sinto totalmente diferente tenho uma outra idéia do que redigir um artigo. 


\section{Questionário respondido pela Simone}

\section{O que mais atraiu você em relação ao tema escolhido? Por quê?}

Pensei em falar sobre alimentos transgênicos porque é um assunto que muitos já ouviram falar, mas que poucos sabem o que realmente é, sendo assim resolvi ir atrás de informações e escrever sobre eles.

\section{Como você se sente escrevendo um artigo de divulgação?}

Sinto-me muito bem. No início confesso que fiquei meio insegura se iria ou não dar certo, se eu conseguiria ou não, mas agora me sinto mais segura para escrevê-los e tenho aprendido muito com tudo isso.

3. Você acha que dominou as ferramentas para montar artigos de divulgação científica? De que forma as incorporou?

Acredito que sim. Em todo o processo de construção do artigo nós incorporamos essas ferramentas desde as pesquisas iniciais até a hora em que começamos a redigir o artigo.

4. Cite os passos básicos que você usou para montar seu artigo.

Fui por etapas. Em primeiro lugar li muito sobre o assunto, pesquisei bastante, entrei em vários sites para saber mais sobre o assunto, e quando me senti segura para começar a escrever fui colocando tudo aquilo que eu julgava importante divulgar, é claro que enquanto escrevo o artigo sempre tem uma informação ou outra que volto a pesquisar para entender melhor e poder colocar no artigo.

5. Hoje você saberia mostrar a diferença entre um artigo científico e um artigo de divulgação? Aponte alguns exemplos.

Acredito que saberia sim. Um exemplo muito claro disso é sem dúvida a linguagem que se utiliza em ambos os artigos. Em um artigo científico a linguagem é muito técnica, dificilmente um cidadão comum conseguiria entender o que está escrito lá. Por outro lado o artigo de divulgação científica utiliza uma linguagem muito mais simples, utiliza termos que permite a quem lê uma fácil compreensão do conteúdo.

\section{Para você, então, o que é divulgação científica?}

Acredito que divulgação científica seja passar todo o nosso conhecimento sobre determinado assunto às outras pessoas. É de extrema importância fazer trabalhos como esses, porque muitas vezes as pessoas já ouviram falar sobre o assunto, sabem algumas poucas coisas sobre ele, ou sabem e a informação que tem muitas vezes é errada, então quanto mais se divulgar melhor a sociedade se torna em questões de conhecimento e para expressar a sua opinião sobre os fatos. 


\section{Se tivesse que passar o que aprendeu adiante, como você o faria?}

Iria por partes. Primeiro iria querer ver até que ponto as pessoas conheciam sobre o assunto e a partir dessa informação começaria a trabalhar, mostrando alguns artigos discutindo sobre eles e etc.

8. Você se acha capaz de comandar um pequeno grupo em um trabalho de divulgação científica? Por quê?

Seria um desafio para mim, mas eu tentaria. Já estamos a quase um ano trabalhando nisso então acredito que agora seria mais fácil, mas é claro que quero e tenho muito a aprender, conhecimento nunca é demais.

9. O que mais gostou e o que menos gostou na hora de redigir seu artigo?

Não é o que menos gostei é o que mais acho cansativo, que é o período das pesquisas, que exige muito tempo e uma concentração muito grande na hora de ler. O que mais gostei foi justamente da hora de começar a escrever, porque é quando começo a perceber o quanto eu aprendi e o quanto eu estou podendo passar pra quem vai ler. É engraçado porque o que mais gosto de fazer depende daquilo que eu mais acho cansativo, entretanto todo esforço é necessário, é realmente muito cansativo pesquisar, mas o esforço que se teve com isso se reflete diretamente no resultado do artigo que se escreve.

10. Como você se classificaria hoje depois de redigir alguns artigos? Explique como se sentiu na primeira vez e como se sente hoje.

Nem sei muito bem como me classificaria, porque acho que tenho muita coisa pra melhorar, mas em relação ao que era antes, já notei algumas mudanças. Confesso que no primeiro artigo que escrevi me senti muito insegura, eu nem fazia idéia do que era um artigo de divulgação científica, fora os problemas técnicos que ocorreram comigo (RS, mas faz parte), resumindo foi horrível. Hoje já me sinto mais segura para escrever, já sei o que fazer para escrever um bom artigo, já sei por onde começar, então fica muito mais fácil. 


\section{Questionário respondido pela Mônica}

\section{O que mais atraiu você em relação ao tema escolhido? Por quê?}

Com certeza foi por ser um tema bem comentado atualmente, e de demasiada importância a população entender o que realmente se passa em relação a Gripe A, e tomar as medidas de precaução necessária. Além do mais a gripe A, é algo novo que despertou minha curiosidade.

2. Como você se sente escrevendo um artigo de divulgação?

Sinto-me bem e realizada, pois para escrever um artigo se passa por todo um processo de pesquisa e estudo. Quando você ver seu artigo finalizado a sensação é muito boa.

3. Você acha que dominou as ferramentas para montar artigos de divulgação científica? De que forma as incorporou?

Acredito que sim, eu as incorporei na prática e também lendo alguns artigos de divulgação científica( o que é bem importante)

\section{Cite os passos básicos que você usou para montar seu artigo.}

*Escolha de um bom tema, que seja importante, atual e principalmente que a população precise ter conhecimento;

*Pesquisas e estudos: Busca em sites, revistas, jornais, livros, etc., tudo o que possa ser útil para a montagem do artigo, para que ele fique conciso e com conteúdo;

*Montar um esboço do que será seu artigo, lembrando que a linguagem utilizada precisa ser de fácil compreensão para que não se torne cansativa para o leitor e que o faça entender;

*Ler e reler seu esboço, observando se não falta nenhuma informação;

*Criar seu artigo de divulgação científica e um título também;

*(Opcional) Colocar alguma figura ou charge;

* Finalmente tem ele pronto!

(Depois do meu artigo pronto geralmente eu entrego ele para alguém ler e ver se ficouy bom.)

5. Hoje você saberia mostrar a diferença entre um artigo científico e um artigo de divulgação? Aponte alguns exemplos.

Sim. O artigo de divulgação científica é direcionado a população em geral, contando que em sua maioria, lida com pessoas leigas sobre o assunto, ele informa, por isso mesmo a linguagem utilizada é de fácil compreensão e podem vir com algum tipo de charge, etc. Um artigo científico é algo mais formal, e usa uma linguagem bem 
científica mesmo e possui algumas etapas a mais que o artigo de divulgação científica não possui.

\section{Para você, então, o que é divulgação científica?}

Divulgação científica é um meio pelo qual a ciência chega a população. Ou seja, a forma como ela é divulgada e levada a todas as pessoas. São muito importantes os meios de Divulgação científica, eles permitem que as pessoas se mantenham atualizadas e informadas de forma correta.

\section{Se tivesse que passar o que aprendeu adiante, como você o faria?}

Explicaria a importância da divulgação científica para a sociedade, propondo debates etc., também mostraria textos de divulgação científica e explicaria a etapa de como construir um artigo com esse aspecto. Proporia a construção de um de uma forma divertida.

8. Você se acha capaz de comandar um pequeno grupo em um trabalho de divulgação científica? Por quê?

É claro que preciso estudar mais e adquirir mais informações, mas com o que sei creio que conseguiria comandar um pequeno grupo, pois o básico eu sei e acho um trabalho bem legal.

9. O que mais gostou e o que menos gostou na hora de redigir seu artigo?

O que mais gostei foi de escrever o esboço, o artigo final e escolher os títulos. As partes das pesquisas eu não gostei muito, entretanto são de muita importância e não se pode pular esta etapa, até porque há dados que não batem e é necessário um pesquisa melhor...Esta é a parte que dá mais trabalho.

10. Como você se classificaria hoje depois de redigir alguns artigos? Explique como se sentiu na primeira vez e como se sente hoje.

Realizada. A primeira vez que o tema foi DNA foi o pior, eu estava "perdida" e não fazia idéia de como fazer, até porque o maior contato que tive com o tema DNA foi o filme GATTACA. Entretanto eu consegui aprende muitas coisas pesquisando, mas não consegui fazer um artigo de divulgação científica correto. $\mathrm{O}$ segundo tema foi célulastronco, foi muito melhor. Já tinha uma idéia de como realizar um artigo e conhecia um pouco o tema, além do mais a parte de pesquisa foi bem mais fácil. De todos os artigos, acredito que foi o que melhor entendi e redigi. O terceiro foi tema livre, gostei de como o escrevi, a maior dificuldade foi que os dados da pesquisa não estavam batendo, como por exemplo, em que mês surgiu a gripe. Enfim, hoje eu me sinto realizada por ter escrito os artigos, diferente da menina "perdida" da primeira experiência. 


\section{Questionário respondido pela Soraia}

\section{O que mais atraiu você em relação ao tema escolhido? Por quê??}

Pra ser sincera, de inicio eu não sabia muito sobre o tema,mais quando soube do que se trataria eu me interessei .

2. Como você se sente escrevendo um artigo de divulgação?

Eu me sinto com um aprendizado “AVANÇADO”!

3. Você acha que dominou as ferramentas para montar artigos de divulgação científica? De que forma as incorporou?

Dominar...Eu não dominei...Mais aprendi bastante ao ponto de consegui montar um artigo e em breve dominar essas ferramentas!

4. Cite os passos básicos que você usou para montar seu artigo.

Muita pesquisa e leitura.

5. Hoje você saberia mostrar a diferença entre um artigo científico e um artigo de divulgação? Aponte alguns exemplos.

Um artigo cientifico penso que é aquele na qual mostra as informações bem a fundo,mostrando detalhes, já o de divulgação cientifica é aquele que tenta transmitir informações básicas sobre determinados assuntos para qualquer tipo de pessoa!

6. Para você, então, o que é divulgação científica?

Sei que é meio Obvia minha resposta mais, é divulgar algum assunto relacionado a ciência,divulgar resultado de experiências,novas descobertas cientificas!

7. Se tivesse que passar o que aprendeu adiante, como você o faria?

Bom , seria um pouco difícil no meu caso,pois eu sou daquelas que aprende e tem dificuldades de explicar, mais eu faria de tudo pra explicar de uma forma simples o que eu me esforcei pra aprender,eu daria alguns artigos bem simples para lerem,e explicar a diferença de um artigo de divulgação cientifica e um artigo cientifico ,para que facilitasse o aprendizado.

8. Você se acha capaz de comandar um pequeno grupo em um trabalho de divulgação científica? Por quê?

De comandar eu não sou capaz, pois eu não sei tudo sobre esse "assunto". Mais seria capaz de Auxiliar com certeza.

9. O que mais gostou e o que menos gostou na hora de redigir seu artigo?

O que eu mais gostei foi descobrir muitas coisas na qual eu não imaginava, e aprender sobre variados assuntos nas minhas pesquisas para redigir um artigo, e o que eu menos 
gostei foi a dificuldade que encontrei para colocar no papel as informações que eu tinha em mãos para forma um artigo.

10. Como você se classificaria hoje depois de redigir alguns artigos? Explique como se sentiu na primeira vez e como se sente hoje.

Eu me sinto uma garota com uma visão diferente de algumas coisas, na qual eu adquiri informações, que por sinal são muito boas. Na primeira vez que eu escrevi um artigo eu não tinha a noção de como era ESCREVER UM ARTIGO, mais agora eu já sinto uma certa facilidade de escrever um, pois eu aprendi como colocar no papel as informações! 


\section{Questionário respondido pela Andressa}

\section{O que mais atraiu você em relação ao tema escolhido? Por quê??}

Eu escolhi a influenza A (H1N1), pois esse é o tema que esta mais na mídia e no nosso cotidiano hoje em dia. Depois de ter sido classificada como pandemia todos ficaram ligados na sua proliferação e mortes, e eu também fiquei. Enfim eu a escolhi pois é uma doença nova e da qual todos tem medo.

2. Como você se sente escrevendo um artigo de divulgação?

Eu me sinto muito bem, pois alem de gostar de escrever gosto também de transmitir o que eu sei para as pessoas, e o artigo de divulgação une esse dois pontos.

3. Você acha que dominou as ferramentas para montar artigos de divulgação científica? De que forma as incorporou?

Eu acho que sim, pois na primeira vez que fui construir um artigo eu estava perdida e acabei cometendo alguns erros, hoje após ler alguns artigos acho que estou mais apta para construir um.

4. Cite os passos básicos que você usou para montar seu artigo.

Primeiro tem que saber como faz um artigo de divulgação. Após isso tem que se informar sobre o assunto lendo em várias fontes confiáveis tudo relacionado ao tema, após isso é só juntar todas as informações e acrescentar a sua opinião pois todo artigo que se preze levanta uma questão controversa.

5. Hoje você saberia mostrar a diferença entre um artigo científico e um artigo de divulgação? Aponte alguns exemplos.

Sim, um artigo de divulgação é aquele feito para leigo com termos mais simples e que explica tudo de um jeito mais fácil de entender. Já o artigo cientifico é usado termos técnicos e direcionado para especialistas da área.

6. Para você, então, o que é divulgação científica?

Uma divulgação de algo onde é usado termos técnicos e complexos, especialmente feita para cientistas e/ou profissionais da área.

7. Se tivesse que passar o que aprendeu adiante, como você o faria?

Organizaria grupos, e faria exatamente do mesmo jeito que eu aprendi, com o auxilio de filmes e sites auxiliando quando necessário, mas deixando eles aprenderem com os erros.

8. Você se acha capaz de comandar um pequeno grupo em um trabalho de divulgação científica? Por quê? 
Sim, mas com auxílio de uma pessoa pois eu consigo passar o que eu aprendi, porém eu sei que para comandar um grupo, por menor que ele seja, tem que ter mais habilidades das quais eu não tenho.

9. O que mais gostou e o que menos gostou na hora de redigir seu artigo?

Para ser sincera não teve nenhuma parte da qual eu não tenha gostado, é bom saber que o que você esta escrevendo possa transmitir um pouco mais de conhecimento para as pessoas. As três partes básicas para redigir um artigo eu gosto: Pesquisar, ler e escrever. Então não há o que eu não goste.

10. Como você se classificaria hoje depois de redigir alguns artigos? Explique como se sentiu na primeira vez e como se sente hoje.

Eu me classificaria como uma boa escritora de artigos, pois agora alem de saber diferenciar um artigo de divulgação e um cientifico hoje eu também já peguei as Na primeira vez eu estava perdida. Como todos do meu grupo, fiz um artigo de divulgação cientifica. a 


\section{Questionário respondido pelo Pedro}

1. O que mais atraiu você em relação ao tema escolhido? Por quê?

A necessidade de ressaltar a importância da Amazônia para o mundo, pois sempre se fala da Amazônia, dos problemas causados pelo desmatamento, dos animais em extinção e etc., mas na maioria das vezes se esquece da sua importância.

\section{Como você se sente escrevendo um artigo de divulgação?}

Fazendo ciência, para escrever eu precisei pesquisar e ler muito. Além de escrever, para passar a informação nos meus artigos, os artigos e sites que eu li, me passaram muita informação. E ao mesmo tempo que eu aprendia, eu divulgava.

3. Você acha que dominou as ferramentas para montar artigos de divulgação científica? De que forma as incorporou?

Acho que sim. Em minhas pesquisas eu comecei a ser mais seletivo com relação às fontes, desconfiei mais de sites que me pareciam meio suspeitos, agora eu não me contento só com o primeiro site.

Na escrita eu tentei simplificar ao máximo a informação para uma melhor compreensão;

4. Cite os passos básicos que você usou para montar seu artigo.

Escolha do tema (eu mudei várias vezes de tema) antes de me decidir pela amazônia;

Pesquisas e mais pesquisas, alguns sites livros e textos

Comecei articulando as idéias e parti pra escrita utilizando os textos e informação como base.

5. Hoje você saberia mostrar a diferença entre um artigo científico e um artigo de divulgação? Aponte alguns exemplos.

Sim. O artigo científico visa simplesmente analisar e discutir um determinado assunto, já o artigo de divulgação científica, ele visa divulgar o assunto a população leiga, para que ela também saiba discutir sobre o assunto com a informação correta.

\section{Para você, então, o que é divulgação científica?}

Trazer a ciência mais pra perto da população, de forma que as pessoas se interessem por ciências e não critiquem antes de conhecer

7. Se tivesse que passar o que aprendeu adiante, como você o faria?

Escrevendo, seria interessante escrever sobre o que eu aprendi.

8. Você se acha capaz de comandar um pequeno grupo em um trabalho de divulgação científica? Por quê? 
Comandar não. Ainda tenho algumas falhas para corrigir em meus artigos. Entretanto, creio, ter compreendido o verdadeiro significado da divulgação científica.

9. O que mais gostou e o que menos gostou na hora de redigir seu artigo?

O que eu mais gostei foi escrever, por as minhas ideias, me expressar através da escrita, e ao final reler o artigo e ver que fui eu quem o fez. E que nele as pessoas poderão entender um pouco mais sobre ciência. Na hora de redigir não teve algo que eu não gostasse.

10. Como você se classificaria hoje depois de redigir alguns artigos? Explique como se sentiu na primeira vez e como se sente hoje.

Agora eu tenho uma noção melhor do que é divulgação científica e da sua importância, pois as pessoas se interessam e discutem aquilo que conhecem. Quando não se sabe sobre determinado assunto, o interesse por ele vai ser mínimo, por isso a importância da informação correta.

A primeira vez eu me senti meio inseguro, de não estar fazendo da maneira certa, até por que eu não tinha noção nenhuma sobre um artigo de divulgação científica.

Agora eu já me sinto mais seguro até com relação as pesquisas, com as fontes confiáveis 


\section{ANEXO VIII}

$6^{a}$ fase de dados

Domínio das ferramentas necessárias para a elaboração de um artigo e relatório final contendo a avaliação dos alunos sobre seu desempenho no projeto, principalmente em relação ao ato de transferir a ferramenta para outros alunos (agosto a outubro de 2009)

(Os artigos foram reproduzidos de forma integral e os nomes dos alunos foram trocados para preservar sua identidade.) 
Pré-Iniciação Científica da USP

Faculdade de Educação

E.E. Prof ${ }^{a}$ Hadla Feres

Comunicação científica na sala de aula de ciências da escola média

\section{CARTILHA PARA ELABORAÇÃO DE ARTIGO DE DIVULGAÇÃO CIENTÍFICA}

\begin{tabular}{cc}
\multicolumn{2}{c}{ GRUPO } \\
Mônica & $2^{\circ} \mathrm{C}$ \\
Simone & $2^{\circ} \mathrm{C}$ \\
Andressa & $2^{\circ} \mathrm{C}$ \\
Pedro & $3^{\circ} \mathrm{A}$ \\
Soraia & $3^{\circ} \mathrm{A}$ \\
Carla & $2^{\circ} \mathrm{B}$ \\
& \\
Professor Orientador: Prof ${ }^{o}$ Dr ${ }^{\circ}$ Aguinaldo Arroio \\
e Professora Luciane Baião
\end{tabular}

\section{ALUNOS}

Júlia $\quad 2^{\circ} \mathrm{B}$

Sandra $\quad 2^{\circ} \mathrm{B}$

Carlos $\quad 2^{\circ} \mathrm{C}$

Ana $\quad 2^{\circ} \mathrm{C}$

Paula $\quad 3^{\circ} \mathrm{A}$

Daniel $\quad 3^{\circ} \mathrm{A}$ 


\section{4 de setembro de 2009}

\section{Passando os conhecimentos à frente}

Depois de realizadas várias atividades de pesquisa e confecção de artigos, nós alunos do Pré-Iniciação Científica da USP, recebemos a missão de passar nossos conhecimentos e experiências com divulgação científica para outros alunos da rede de ensino.

Desde já, agradecemos à vocês, alunos pela colaboração conosco em nosso trabalho.

\section{Oque é divulgacão científica?}

Os muitos assuntos abordados pela ciência, em especial os mais polêmicos devem ser divulgados à população a fim de que, com o conhecimento as pessoas também façam ciência.

Na era da internet informação é o que não falta, mas nem sempre essa informação é confiável, o que leva as pessoas a criarem uma opinião equivocada, baseada em fundamentos ultrapassados ou até, contrários à verdade. E por isso na divulgação científica se deve sempre basear-se em informações de fontes confiáveis, para passar a informação correta àqueles que são leigos no assunto.

$\mathrm{Na}$ divugação científica, ao mesmo tempo que deve transmitir informações científicas concretas, deve-se fazê-lo de forma fácil de compreender sem "popularizar" muito, e de forma que não fique cansativa, cativando assim, o interesse da pessoa por ciência, motivando-a à pesquisar por seus próprios meios e tendo base para uma opinião concisa.

\section{$\underline{\text { Artigo de Divulgacão Científica }}$}

Você já deve ter lido em alguma revista ou jornal um artigo sobre algum assunto relacionado a ciência, não?

Nele, o autor ao desenvolver seu tema, nos dá o máximo de informação possível sobre ele. Para isso, é necessário muita pesquisa, muita leitura para o autor saber bem articular a suas ideias, e até mesmo a sua opinião de forma clara.

A opinião, de preferência, quando se trata de um assunto de bastante divergências entre a população, não deve ser colocada como verdade absoluta, deixando espaço para o próprio leitor conseguir captar a informação e criar a sua opinião.

Desde o seu início ao seu término deve ser escrito de forma compreensível à toda a população, mas com muito cuidado para não se tornar fugir do assunto e nem passar a 
informação errada. Não se deve esquecer que há termos que devem realmente ser usados, porém devem estar num contexto taambém compreensível, para que o leitor não se canse logo nas primeras palavra difíceis ou termos científicos.

\section{$\underline{\text { Como construir um artigo de Divulgacão Científica }}$}

Passos:

1-Escolha do tema

É interessante escolher um tema que seja atual e de importância para a sociedade, que possa informar de uma forma agradável.

\section{2-Pesquisa}

É um dos pontos mais importantes, é a base para a construção de um artigo. Por isso requer atenção e muita leitura, procurando entrar em sites que sejam confiáveis e não se contentar apenas com uma informação, mas consultar várias fontes.

\section{3-Esboço}

É um rascunho do que será o artigo, onde serão inseridas, as idéias adquiridas através da pesquisa, servirá para que haja uma confirmação dos dados que foram obtidos pela pesquisa. Coloque suas idéias!

\section{4-Construção do artigo}

Depois de confirmar e de analisar os dados é sua vez de escrever! Com base no resumo e nas pesquisas, procure escrever um texto onde as pessoas leigas possam entender, não use termos muito difíceis, seja conciso e criativo! Não esqueça de reler seu artigo depois de pronto, para corrigir os erros e confirmar se o artigo está de fácil compreensão. Consultar o dicionário para entender algum termo ou para procurar uma palavra que se encaixe melhor na informação que você quer passar é uma boa alternativa.

\section{Mãos à obra!}

Agora é a vez de vocês!!!

Com base no que passamos à vocês, em nossos artigos e sob a nossa orientação, agora vocês terão que escrever um artigo de divulgação científica, cada um será orientado por um de nós, alunos do Pré-Iniciação Científica.

\section{Segue aqui os nossos artigos e respectivos contatos contatos:}

\section{Mônica}




\section{Tel: $X X X X-X X X X$}

\section{Cel: $X X X X-X X X X$}

E-mail:mmm@mmm

\section{Gripe Suína: Um desafio?}

O mundo em que vivemos está sempre em constante mudança e transformação. $\mathrm{O}$ tempo passa, as tecnologias avançam, curas e doenças vão surgindo... $\mathrm{O}$ homem precisa está preparado para isso. O que acontece muitas vezes é que essas informações chegam de supetão, assustando qualquer um. É o caso da nova gripe, a gripe suína que tem deixado muita gente de cabelo em pé!

A OMS (Organização Mundial de Saúde) declarou a gripe suína como ameaça de nível 6, o que indica uma pandemia. Numa epidemia o número de casos de uma determinada doença aumenta mais do que aquilo que é considerado habitual. Pandemia é uma epidemia que atinge uma área geográfica muito grande, em geral toda a Terra.

A gripe suína, também conhecida como " gripe Porcina”, trata-se do vírus Influenza A $H 1 N 1$, sendo que o vírus Influenza A é muito transmissível e mutável, é um subtipo do vírus da gripe comum. " $H$ " refere-se a proteína hemaglutina e " $n$ " a proteína Neuraminidase .Esta doença é adquirida através de uma infecção viral que atinge o sistema respiratório.

O contágio se dá através do contato com porcos infectados ou ambientes onde os porcos poderiam está presentes. Contudo, alguns casos humanos não envolviam este contato, mostrando a transmissão direta entre seres humanos.

Vale ressaltar, que mesmo recebendo o nome de "gripe suína", não há nenhum tipo de transmissão pela carne do porco, até porque antes de ser consumida passa por processos de higienização, como o cozimento a $70{ }^{\circ} \mathrm{C}$.

O primeiro caso de gripe suína surgiu na cidade de La Gloria, estado de Vera Cruz no México, em meados de fevereiro. O México tornou-se o lugar onde a doença estava mais disseminada e focalizada, entretanto começou a se expandir para lugares como E.U. A, Áustria, Canadá, China, Dinamarca, França, Alemanha, Israel, Chile, Holanda Nova Zelândia, Coréia do Sul, Espanha, Suíça, Reino Unido, Brasil, Argentina entre outros.No total somam 73 países.

Como qualquer outra gripe, esta também pode matar, embora a taxa de mortalidade tenha sido bem baixa e as chances remotas, cera de $1,2 \%$,número que tende a cair. Ela 
possui cura, há remédios antivirais para gripe sazonal (Influenza Sazonal) que se mostram eficientes, como o medicamento Oseltamivir. Ainda não há vacina preventiva. Os sintomas não são muito diferentes da gripe comum, basicamente são dores musculares, dor de garganta, coriza, febre alta e tosse sem secreção, algumas pessoas também podem apresentar vômito e disenteria. Ao apresentar esses sintomas é importante ficar em casa de repouso, afastado do trabalho, escola ou qualquer lugar público.Tomar muito líquido e procurar um médico, nunca ingerir medicamentos sem prescrição.

Medidas de prevenção podem e devem ser tomadas, como higienizar as mãos; evitar tocar os olhos, nariz ou boca após contato com superfícies; ao tossir ou espirrar proteger com lenços a boca e o nariz( descartáveis se possível); evitar contato com pessoas infectadas, caso não possa evitar esse contato, é correto usar máscaras cirúrgicas; manter ambientes com boa circulação de ar e cuidar bem da saúde.

Ao viajar também é importante manter essas medidas, e procurar evitar o contato com pessoas que apresentem os sintomas.

O tempo de incubação varia de $24 \mathrm{~h}$ a 3 dias. As pessoas que apresentam doenças crônicas ou deficiências imunológicas, sempre estão mais propícias.

No Brasil já foram confirmados mais de 900 casos, sendo que o estado de São Paulo compreende a maioria. $\mathrm{O}$ vírus Influenza A dissemina-se pela Terra, a ciência trabalha para contê-lo e controlá-lo, afinal é um novo desafio para a humanidade.

\section{Simone}

Tel: $X X X X-X X X X$

Cel: $X X X X-X X X X$

E-mail: $\underline{\mathrm{mmm} @ \mathrm{mmm}}$

\section{Células-tronco: Afinal, quem tem a razão?}

Desde o ano 2005, quando foi aprovada a lei que permite as pesquisas com célulastronco embrionárias retiradas de embriões que tenham no mínimo três anos de congelamento, e mesmo antes da aprovação da lei, o assunto células-tronco é o que mais gera polêmicas e causa divergências no mundo científico.

Há aqueles que são a favor das pesquisas, outros são contra, há também aqueles que se encontram divididos e há aqueles cuja informação lhes falta. Vemos o assunto ser debatido na televisão, no rádio, estampados nos jornais e revistas e ainda assim, alguns 
ainda sofrem com a falta de informação, fazendo com que estes não tenha uma opinião formada em relação ao assunto e que, por esse motivo, acabam se deixando influenciar pelo lado mais comodo da situação.

Células- tronco, são células que tem a capacidade de dar origem a qualquer tecido do corpo, de acordo com a sua potencialidade.

As células- tronco podem ser tanto embrionárias quanto adultas. As células-tronco embrionárias são encontradas nos embriões, enquanto que as células - tronco adultas são encontradas em tecidos como a medula óssea, a placenta, o cordão umbilical, polpa do dente, resumindo em qualquer tecido do corpo que esteja completamente desenvolvido.

As células-tronco são classificadas de acordo com a sua potencialidade, ou seja, significa dizer que nem todo tipo de células-tronco tem a mesma capacidade de diferenciação. Elas são classificadas da seguinte maneira:

- $\quad$ Totipotentes: São células que tem a capacidade de dar origem a qualquer tecido do corpo, sem exceção.

- $\quad$ Pluripotentes: São as células capazes de dar origem a todos os tipos celulares de um embrião, com exceção da placenta e anexos.

- $\quad$ Multipotentes: São capazes de produzir diversificados tecidos.

- $\quad$ Oligopotentes: Células com uma capacidade reduzida de originar outros tecidos, mas ainda assim os originam, mesmo que pouco.

- Unipotentes: Células capazes de originar um único tecido do corpo.

O que diferencia as células-tronco de qualquer outro célula é justamente a sua capacidade de originar outros tecidos. Entretanto, há diferenças entre as células-tronco embrionárias e as células-tronco adultas, uma vez que as células-tronco adultas, tem um poder de diferenciação menor do que as células-tronco embrionárias.

As células-tronco originadas de embriões tem uma capacidade imensa de diferenciação, sendo assim é possível dizer que essas células são totipotentes, o que chama ainda mais a atenção dos cientistas para pesquisas com esse tipo de célula.

Mediante a uma enorme polêmica acerca da lei, vem em nossas cabeças à questão que não quer calar: Afinal, quem tem a razão a razão?

Difícil responder a uma questão desse gênero uma vez que somos "bombardeados" por argumentos vindos de todos os lados.

É a Igreja Católica que abomina a prática de tais pesquisas, são os cientistas que alegam querer defender a vida daqueles que realmente existem e que merecem ter uma chance de recuperação. 
Com tantas explicações fica difícil tomar partido de algum lado, pois o que talvez nunca saibamos é quem realmente tem a razão.

A grande polêmica e que gera conflitos não apenas entre Igreja e cientistas, mas sim até mesmo entre os próprios cientistas, é o fato de não se saber ao certo quando se dá início à vida.

Segundo a Igreja, desde o momento da concepção o embrião já tem vida, o que pra alguns cientistas é um absurdo poder afirmar com certeza, uma vez que não está provado cientificamente onde começa a vida.

Para a ciência o período ideal para a retirada dessas células-tronco totipotentes (encontradas apenas nos embriões), seria até o período do blastocisto, que é onde o embrião atinge uma quantidade de 32 a 64 células e a partir daí passará a formar alguns tecidos.

A partir dessas informações dá para se ter uma idéia da quantidade de opiniões que se dividem. No entanto, sabemos que essa é apenas uma das tantas explicações para tais conflitos entre ciência e religião.

O importante de tudo isso é se informar sempre sobre o assunto, e a partir de então poder tirar as nossas próprias conclusões sobre a grande polêmica que é gerada em torno das células-tronco e a partir de então quem sabe um dia podermos ter as respostas, para tantas perguntas.

\section{Andressa}

Tel: $X X X X-X X X X$

Cel: $X X X X-X X X X$

E-mail: $\underline{\text { mmm@mmm }}$

\section{A $1^{\text {a }}$ PANDEMIA DO $3^{\circ}$ MILÊNIO}

Muito parecida com a gripe comum, porém prima próxima de varias outras gripes que já assombraram tanto esse mundo, tais como a gripe espanhola, a gripe russa e tantas outras, a gripe suína ou no seu nome cientifico influenza A (H1N1) após ter seus primeiros casos no mês de março no México, virou pandemia no dia 25 de Abril de 2009.

Após o paciente zero, Édgar Hernández de apenas quatro anos, a gripe suína se espalhou rapidamente pelo globo terrestre e já contaminou cerca de 174.159 e já matou pessoas nos quatro cantos do mundo. 
A gripe suína passou a se chamar influenza A $(\mathrm{H} 1 \mathrm{~N} 1)$ por vários motivos, um deles era o sacrifício e/ou a despensa de porcos por causa do vírus. Este vírus é uma mutação que uniu a influenza humana, a aviaria e a suína. O nome H1N1 refere-se as proteínas existentes no vírus: $\mathrm{H}$ refere-se à proteína hemaglutinina e a letra $\mathrm{N}$ à proteína neuraminidase.

Tanto a mortalidade quanto os sintomas são muito parecidos com o da gripe normal, porém com o aparecimento repentino de febre, tosse, dor de cabeça intensa, dores

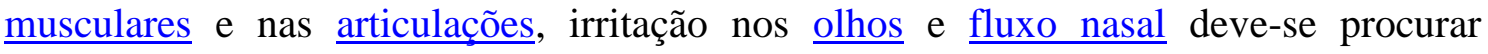
rapidamente um posto médico para a confirmação da gripe.

Enfim, essa nova pandemia tomou conta do mundo todo e não ira parar se alguns cuidados básicos não forem tomados, tais como: Cubra seu nariz e boca com um lenço quando tossir ou espirrar. Jogue no lixo o lenço após o uso; lave suas mãos constantemente com água e sabão, especialmente depois de tossir ou espirrar. Produtos à base de álcool para limpar as mãos também são efetivos; evite tocar seus olhos, nariz ou boca. Os germes se espalham deste modo; evite contato próximo com pessoas doentes; se você ficar doente, fique em casa e limite o contato com outros, para evitar infectá-los.

Pedro

Tel: $X X X X-X X X X$

Cel: $X X X X-X X X X$

E-mail: $\underline{\mathrm{mmm} @ \mathrm{mmm}}$

\section{MANIPULAÇÃO GENÉTICA: A ÉTICA DA IGREJA}

\section{Papa condena manipulacão genética e fecundacão artificial}

O Papa João Paulo II pediu ontem o reconhecimento jurídico do embrião humano, em 'particular seu direito fundamental à vida', durante o ângelus na Praça São Pedro. Ele lembrou que todo ser humano deve 'ter garantido seu direito de se desenvolver segundo seu próprio potencial e assegurada a inviolabilidade da concepção até a morte natural'. - Ninguém, destacou o Papa, é dono da vida, ninguém tem direito de manipular, oprimir ou tirar a vida, seja a do próximo ou a sua própria, e ainda menos fazê-lo em nome de Deus - acrescentou. O novo chamado do Papa em favor da vida condena o aborto, a eutanásia, a manipulação genética, a fecundação artificial e 'quem mata em nome de Deus'.

$\underline{\text { Retirado de: http://comrainhadapaz.br.tripod.com/comunidaderainhadapaz/id11.html no }}$ 


\section{dia 21/04/2009 às $12 \mathrm{h37}$}

É de conhecimento público a posição da Igreja Católica com relação a todo e qualquer tipo de manipulação genética, de fato, a Igreja Católica se mostra contra, e isso gera uma enorme polêmica dentre a população. Tanto para a Igreja Católica quanto para a Ciência a manipulação genética é um assunto que deve ser bem discutido. Deve-se analisar os vários os ponto-de-vistas de cada um no âmbito de se chegar a uma conclusão concreta antes de dizer preconceituosamente "que a Igreja quer controlar à tudo e à todos" ou "a ciência é ateia". Mas, você já se perguntou quais são os argumento que a Igreja apresenta por ser contra a manipulação genética? Esses argumentos são satisfatórios? Por que muitos cientistas discordam de tais argumentos? Este artigo responderá à algumas dessas perguntas.

\section{A posição da Igreja}

Segundo a doutrina da Igreja Católica, (e de outras igrejas também) Deus é o criador de tudo e de todos e somente ele pode dar, "modificar" (processo evolutivo natural) ou tirar a vida, "A ninguém é lícito destruir diretamente um ser humano inocente, sendo isso gravemente contrário à dignidade da pessoa e à santidade do Criador" (Compêndio do Catecismo da Igreja Católica, n466 da página 144).

\section{O embrião, ser humano?}

Para a Igreja manipular um ser em sua formação, um embrião, modificando sua estrutura e negando a esse ser o direito de se desenvolver livremente é algo imoral, pois ninguém tem direito sobre a vida de ninguém. É claro que o embrião não é algo intocável, a Igreja concorda que se façam experiências científicas com seres humanos quando essas experiências não lhes comportem riscos desproporcionados, ou quando visa a saúde ou melhorias das condições de saúde e sobrevivência desse ser. Sempre respeitando sua vida e seu direito de desenvolver-se, de forma a não causar sua morte ou "usá-lo" para os mais variados fins como de clonagem e inseminação artificial, que são formas de se "criar" seres humanos com características pré-determinadas, o que vai contra os princípios não só da Igreja Católica mas também vai contra todos os princípios éticos cristãos, e da maioria ou até mesmo de todas as religiões.

\section{A visão dos cientistas}

Para muitos cientistas, o embrião só é considerado ser humano depois de 14 dias de sua concepção, antes desse período ele é chamado de pré-embrião. Uma grande fonte células-tronco totipotentes (ou embrionárias), que são aquelas que podem se 
desenvolver em qualquer tecido do nosso corpo, diferente das células-tronco adultas encontradas em várias partes corpo, que tem menor capacidade de originar outros tecidos, pois as célula-tronco adultas já tem uma "programação" para se desenvolverem em tecidos específicos conforme onde são encontradas. Acredita-se que as células-troco poderão ajudar no desenvolvimento da cura de doenças como Leucemia, Mal de Alzheimer, Mal de Parkinson e até diabete, dentre muitas outras doenças généticas.

\section{A polêmica}

Porém, quando se faz uso de células-troco embrionárias para pesquisas e etc se acaba tendo que descartar o embrião. Aí é que está a polêmica, pois diversos setores da sociedade, principlamente os religiosos fazem fortes objeções às experiências com células-tronco embrionárias pois consideram o embrião como ser humano, desde o momento de sua concepção, ou seja, desde o momento em que o espermatozóide fecunda o óvulo formando um embrião em fase unicelular, um ser humano no início de seu desenvolvimento.

\section{Por que condenar a inseminação artificial?}

O problema surge também, segundo Dom João Bosco Oliver de Faria, Bispo de Patos de Minas, em Engenharia Genética e sociedade, quando as experiências deixam de visar o bem de um embrião para atender ao comodismo e bem-estar dos pais, que querem um filho perfeito segundo seus critérios e não um filho com suas características próprias, decididas pelas seleção natural dos genes do pai e da mãe. Agindo assim, os pais tiram a liberdade do filho de ter um "eu" próprio, para ter um "eu” já determinado por seu pais.

Os cientistas afirmam que a inseminação artificial, é para ajudar casais que não conseguem por meios naturais a terem filhos. Tal prática não é aceita pela Igreja pois não segue os meios naturais que representam a construção da família através dos laços do matrimônio que é consagrado por Deus. Daí muitos contestam afirmando o direito que casais têm de contituir uma família, porém a Igreja não vê um filho como direito mas, como dom de Deus, dom esse que nem sempre é dado aos casais. "O que se condena não é o uso da técnica, mas a separação e um dualismo entre a dimensão biológica fecundativa e a dimensão espiritual do 'EU' esponsal”, diz Dom João Bosco Oliver de Faria, Bispo de Patos de Minas em Engenharia Genética e sociedade. É válido também quando os métodos usados pelos cientistas visam ajudar o casal no ato conjugal, pois a presença do ato conjugal como condição para a procriação digna da pessoa humana se faz necessária para o contexto propriamente matrimonial, mas sempre 
respeitando o direito a vida e o direito de se desenvolver do embrião.

\section{Clonagem reprodutiva ou terapêutica, qual delas é moral?}

Para cada grupo na sociedade, as respostas à essa pergunta irão variar muito. Porém, a Igreja se mantem firme na sua posição contra todo e qualquer ato que venha a modificar a genética de um ser humano(um embrião), ou desperdiçá-lo.

"A obtenção de embriões humanos por clonagem, tanto com fins de reprodução como de terapia e investigação, implicaría na destruição de grande parte deles. Por exemplo, para a ovelha 'Dolly', foi necessário 'desperdiçar' centenas de embriões. Mais ainda, o elevado risco de transmissão de doenças ou malformações que implicaria essa técnica nos leva à novas razões para sua proibição ética. Isto vale especialmente pelo que se entende de clonagem 'terapêutica"', diz o Cardeal Alfonso López Trujillo, presidente do Conselho Pontificio para a Família.

Já o sanitarista e bioeticista Fermin Roland Schramm, em seu artigo A Moralidade da Clonagem (julho de 2002), alega que seja a clonagem reprodutiva lícita ou não, estará extremamente ligada ao aumento da infertilidade, "Deste ponto de vista pode ser considerada um bem pois evita sofrimentos evitáveis. Este tipo de clonagem pode, por exemplo, ajudar casais que queiram ter um filho sem recorrer à reprodução assistida através de um doador externo (chamada heteróloga) ou que queiram selecionar o sexo de sua cria para evitar doenças genéticas ligadas ao sexo." diz ele. Fermin Roland Schramm acredita também que não há nenhum problema moral com a clonagem terapêutica, já que visa a terapia contra doenças de origem genética. “ Portanto, a clonagem terapêutica é moralmente legítima porque permite o desenvolvimento de terapias úteis a um grande número de pessoas, evitando seu sofrimento e melhorando em princípio sua qualidade de vida" alega ele.

Surge então, a discussão de salvar vidas destruindo ou manipulando outras (os embriões). Como já foi dito antes para a Igreja, somente Deus pode dar, "modificar" ou tirar a vida. Entramos também numa já discutido neste artigo: a inseminação artificial e manipulação de embriões, sendo eles considerados seres humanos ou não.

\section{Uma polêmica entre os cientistas}

Entre os muitos cientistas e bioeticistas, se encontra uma grande polêmica quando é discutido que a manipulação genética pode gerar a problemática de muitos a usarem para melhorar a linhagem, ou seja, criar seres humanos perfeitos, saudáveis física e até mesmo psicologicamente, o que geraria um preconceito maior que todos os preconceitos já vistos. Maior que o preconceito por etnia, sexo, idade, orientação sexual e até por 
classes sociais: o preconceito pelo DNA, que não discriminaria negros e brancos, homens e mulheres, jovens ou idosos, homossexuais e heterossexuais, ricos e pobres, mas sim, discriminaria as pessoas, pela sua genética.

Quando se fala em discriminar as pessoas por sua genética, se quer, por exemplo, dizer que as pessoas com à alguma doença seriam inferiores ou menos capazes que as mais saudáveis. De certa forma, tal discussão é exemplificada no filme Gattaca - Experiência Genética, direção de Andrew Niccol, 1997.

\section{Palavras Finais}

Este artigo de divulgação cientifíca não visa dizer quem está certo, se a Igreja (de um modo geral todas a religiões), ou a Ciência. Mas propõe ao leitor que analise os conceitos de ambos e crie sua própria posição.

Tanto a Igreja, quanto a Ciência, possuem uma posição diferente sobre manipulação genética e outros vários assuntos, muitas vezes, tal posição é precipitada por parte da população, e acaba discriminando uma da outra logo aos primeiros acontecimentos mais polêmicos dentre a sociedade que envolvem a ética da Ciência e a ética da Igreja.

Por isso, este artigo explica de forma bem resumida, a visão da Igreja Católica, principal opositora da Ciência no assunto de manipulação genética, e que por isso é, de fato, a mais atacada por diversos órgãos (que não necessariamente a Ciência).

Deve se escarecer que ela se põe contra à assuntos que considera ser contra sua doutrina, mas que tem um fundamento que deve ser, junto com os fundamentos cientificos, analisado e contraposto para que de acordo com as próprias conclusões, ao tomar uma posição, que seja uma posição fundamentada, que tenha analisado os dois lados e chegado a uma conclusão concreta, segundo o que cada um acredita.

\section{Referências:}

- $\quad$ Academia Pontificia para la Vida. Notas históricas. Retirado de: http://www.aciprensa.com/clonacion/documento.htm em 21/04/2009 às 10h58;

- $\quad$ Cardeal Alfonso López Trujillo, Presidente do Conselho Pontifício para a Família. Objeciones técnicas, éticas y antropológicas a la clonación humana. Retirado de: http://www.aciprensa.com/clonacion/lopez-trujillo2.htm em 21/04/2009 às 10h30;

- Compêndio do Catecismo da Igreja Católica, Conferência Nacional dos Bispos do Brasil. n466 da página 144. 2005;

- $\quad$ Faria, João Bosco Oliver de, Bispo de Patos de Minas. ENGENHARIA GENÉTICA E SOCIEDADE. Retirado de: http://www.ghente.org/temas/clonagem/engenharia.htm em 


\section{1/04/2009 às 09h38;}

Kessler.

http://www.algosobre.com.br/biologia/dna-e-rna.htmlem 17/04/2009 às 02:10;

- Machado, Maria Cristina. Sobral, Paula Roque. Barbosa, Maria Cristina. MANIPULAÇÃO GENÉTICA, NORMA JURÍDICAS OU ÉTICAS?. SOCIOLOGIA - PROBLEMAS E PRÁTICAS Nº101991,PP.115-126;

- $\quad$ Notícia: Papa condena manipulação genética e fecundação artificial (16:30 -

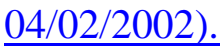
Retirado de: http://comrainhadapaz.br.tripod.com/comunidaderainhadapaz/id11.html em 21/04/2009 às $12 \mathrm{~h} 37$;

- $\quad$ Paiva, Lília Rodrigues. Células-tronco. Benefícios do avanço da ciência genética. Retirado de: http://www.racionalismo-cristao.org.br/gazeta/razao/celulas-tronco.html em 12/06/2009 às $11 \mathrm{~h} 57$;

- $\quad$ Schramm, Fermin Roland. PhD. Bioeticista, Pesquisador Associado da Escola Nacional de Saúde Pública da Fundação Oswaldo Cruz, ENSP/FIOCRUZ, e Consultor em bioética do Instituto Nacional do Câncer, INCA.; A MORALIDADE DA CLONAGEM, Artigo publicado no jornal arte \& política, ano V, número XV, de 26 de julho de 2002, pp. 4-5., retirado de: http://www.ghente.org/temas/clonagem/moralidade.htm em 21/04/2009 às 11h09;

- $\quad$ Senador Leomar Quintanjlha. Parecer do projeto de lei do senado nº 285, de 1999. Retirado de: http://www.ghente.org/doc juridicos/parecer285.htm em 21/04/2009 às $10 \mathrm{~h} 36$.

\section{Nota:}

Carta Encíclica Evangelium vitae, do Papa João Paulo II, sobre o Valor e a Inviolabilidade da Vida Humana 25 de março de 1995.

\section{Soraia}

Tel: $X X X X-X X X X$

Cel: $X X X X-X X X X$

E-mail: $\underline{\text { mmm@mmm }}$

\section{Células-Tronco: $\mathbf{E}$ ai a favor ou contra?}

Muitas pessoas ainda não têm conhecimento sobre a tal "células-tronco" 
E dessa forma não podem chegar a conclusão alguma, apesar de toda repercussão do assunto, mal sabem o que é.Mas,para que possam chegar a uma decisão, segue abaixo algumas informações sobre as células -tronco:

As células-tronco são definidas como células capazes de dar origem aos mais diversos tecidos do organismo, como ossos, cartilagens, nervos, músculos, entre outros.

Células-tronco embrionárias são encontradas no embrião, já as células adultas são encontradas em tecidos que já se desenvolveram, tais como placenta, polpa de dente, gordura de lipoaspiração, entre outros. Elas são classificadas em 5 tipos que são: Totipotentes: são células-tronco que conseguem se diferenciar em todos os 216 tecidos que formam o corpo humano, inclusive placenta e anexos embrionários. É o caso de Zigoto (óvulo fertilizado); Pluripotentes: são as que conseguem se diferenciar nos tecidos provenientes dos três folhetos embrionários (ectoderme, endoderme e mesoderme). Ex. Células da Massa Interna de um Embrião de 5-6 dias; Multipotentes: capazes de originar diversos tecidos; Oligopotentes: capazes de originar poucos tecidos; Onipotentes: capazes de se diferenciar em um único tecido.

As células-tronco embrionárias são as únicas capazes de originar tecidos proveniente dos 3 folhetos embrionários(é uma camada de células (ou tecido primitivo) que aparece no embrião animal logo após a gastrulação. Na organogênese esses tecidos primitivos vão diferenciar-se em órgãos componentes do animal).Em relação ao processo de extração,elas podem ser obtidas da massa interna de um embrião de 5 a 6 dias de fertilização.

Um dos maiores sonhos da pesquisa biomedica é aproveitar toda a potencialidade das celulas-tronco embrionarias para a cura de lesões como as de medula,e de doenças como as cardiacas,o mal de parkinson e diabetes.

Existem muitas pessoas contra o uso de células-tronco,por exemplo a igreja católica e diversos grupos religiosos,pois para eles o ser humano passa a existir a partir do momento em que o óvulo é fecundado pelo espermatozóide .E pela lei abortos são proibidos,fora algumas exceções .Os críticos das pesquisas com células-tronco baseiamse também em outros 2 argumentos :na qual é possível pesquisar outros dois tipos de células-tronco que estão ,no sangue do cordão umbilical dos bebês ,e as adultas que sobrevivem organismo fundamentalmente na medula óssea no decorrer de toda a vida do individuo. Dessa forma os críticos se perguntam por que os pesquisadores não se concentram nessas linhas de pesquisas que não agridam a lei e nem os religiosos?

Além disso, os críticos dizem que as pesquisas com células-tronco embrionárias ainda 
esta no começo e não há garantia de que trará os benefícios prometidos. A representante da Conferência Nacional dos Bispos do Brasil, Zilda Arns disse que:

“A esperança de pessoas doentes serem curadas não vai ocorrer com células-tronco ainda por muitos anos.com certeza estão iludindo essas pessoas".

Em uma entrevista feita com uma Pesquisadora de células-tronco Maria Denise Fernandes Carvalho, foi perguntado a ela algumas coisas em relação a polemica que as células-tronco causa, e ela respondeu que " a principal polemica gerada vem as falta de informação. A parti do momento em que a população busca esclarecimento a polemica desaparece."Perguntamos a ela sobre o uso de células-tronco embrionárias e a ética com relação a ciências e ela respondeu :

“A ciência feita de maneira correta e pelo profissional sério visa sempre o bem-estar. Jamais a ciência poderá considerar antiético aquilo pode melhorar a qualidade de vida de um cidadão."Perguntamos também a respeito da posição da igreja em relação ao uso de células-tronco,ela respondeu que as principais discordâncias originam-se da igreja.

E o que pode ser feito para que isso mude, ela nos deu um exemplo do que ela faz: "eu sou cientista e católica e procuro participar na minha igreja esclarecendo informações com experiências de dentro do laboratório. Assim cada um deve fazer sua parte levando às informações corretas aos leigos".

Agora cabe a você e a sociedade decidir o que é melhor. $\underline{\mathbf{E}}$ ai a favor ou contra?

\section{Carla}

Tel: $X X X X-X X X X$

Cel: $X X X X-X X X X$

E-mail: $\underline{\mathrm{mmm} @ \mathrm{mmm}}$

\section{Aquecimento global e repercussões na saúde}

Há mais de 50 anos têm sido relatados os efeitos da poluição do ar na saúde. São bastante conhecidos os episódios decorrentes da elevação aguda na concentração de poluentes ocorridos no Vale do Meuse (Bélgica, 1930), em Donora (Pensilvânia, 1948) e em Londres, 1952, responsáveis por milhares de internações e óbitos por doenças respiratórias e cardiovasculares. Estes fatos chamaram a atenção do mundo, estimularam a realização de milhares de estudos e induziram os países a adotarem leis ambientais cada vez mais projetivas, mas ainda insuficientes. 
Os estudos epidemiológicos e experimentais realizados têm comprovado, de maneira consistente, que a poluição do ar aumenta o risco de doenças e de mortalidade por doenças cardiovasculares, respiratórias e por câncer de pulmão ${ }^{1-2}$.

Nosso organismo desenvolveu, ao longo de um processo de evolução de milhões de anos, um sofisticado e eficiente mecanismo de defesa contra as doenças infecciosas e outras agressões do meio, possibilitando que chegássemos até quase meados do século passado sem o uso de antibióticos, vacinas e outros medicamentos e procedimentos. É claro, porém, que tal processo deu-se à custa de elevada mortalidade, que foi responsável pela seleção da espécie. Entretanto, não desenvolvemos mecanismos para nos defender dos efeitos gerados a partir da Revolução Industrial (gases, poeiras e radiações), processo recente (250 anos) na evolução da espécie. Nosso organismo reage a estas agressões freqüentemente de maneira parecida a como faz com relação às infecções, muitas vezes levando à lesões em vez da cura.

Ao lado dos efeitos diretos na saúde humana, cientistas têm procurado chamar a atenção para os efeitos dos poluentes no meio ambiente e da degradação ambiental, como a redução das áreas verdes provocada pela atividade humana. Mas as previsões e estudos eram considerados por muitos como catastrofistas, havendo grande resistência por parte dos países mais poluidores a enfrentar o problema apontado.

A recente divulgação do relatório do Painel Intergovernamental sobre Mudança Climática (IPCC) ${ }^{3}$, constituído em 1988 pela Organização Meteorológica Mundial (WMO) e pelo Programa Ambiental das Nações Unidas (UNEP), órgãos vinculados à ONU, conseguiu chamar a atenção de governantes e de grande parte da população para as conseqüências danosas da ação do homem ao meio ambiente. Mesmo os Estados Unidos da América do Norte, que vêm se recusando a assinar o Protocolo de Kyoto, não puderam ficar alheios e contestar as conclusões.

O relatório divulgado em Paris demonstrou de maneira consistente que as alterações na atmosfera com o aumento da concentração dos gases de efeito estufa (que sempre existiram e ajudam a manter a temperatura da terra estável e não muito fria, pois absorvem parte da radiação solar) e o aumento da radiação solar (decorrente da redução da camada de ozônio na estratosfera, provocada pela emissão de clorofluorcabonos (CFCs) que, sob ação da luz ultravioleta do sol, libera cloro que reage e elimina o ozônio) são responsáveis pelo ritmo do aquecimento global observado.

As previsões apontam que até o final deste século a temperatura da Terra poderá aumentar em até quatro graus, com repercussões globais como as decorrentes da 
elevação média do nível do mar em até $60 \mathrm{~cm}$, devido ao derretimento do gelo das calotas polares, caso os níveis de emissão de gases não sejam drasticamente reduzidos. O Relatório apresenta também dados sobre a concentração de gases de efeito estufa nos últimos dez mil anos, demonstrando que seu aumento relevante teve início a partir de 1750, com importante incremento nos últimos 50 anos. A concentração de dióxido de carbono $\left(\mathrm{CO}_{2}\right)$, o mais importante dos gases de efeito estufa gerado pela atividade do homem (outros são o metano, óxidos nitrosos, ozônio) passou de 280 ppm (partes por milhão), na era pré-industrial, para 379 ppm, em 2005, com aumento exponencial nas últimas décadas. A taxa de crescimento de $\mathrm{CO}_{2}$ nos últimos dez anos (1995-2005) foi de 1,9 ppm/ano, contra 1,4 ppm/ano no período de 1960-2005. Elevação semelhante foi observada para os óxidos nitrosos e o metano, todos relacionados à queima de combustíveis fósseis (derivados do petróleo, carvão) e de biomassa (queimadas de canade-açúcar e de florestas).

Os dados comprovam também que com o aumento das concentrações dos gases de efeito estufa (assim chamados por absorverem radiação solar e aumentarem o aquecimento na superfície da Terra - a troposfera), verifica-se um correspondente e concomitante aumento da temperatura, da velocidade de derretimento das geleiras polares e da elevação do nível do mar.

Ao mesmo tempo em que este processo ocorre, a eliminação de áreas verdes e a redução de fito plâncton nos oceanos pela ação da radiação ultravioleta que atinge a superfície da Terra em maior quantidade devido à redução da camada de ozônio, reduzem a capacidade de extração de $\mathrm{CO}_{2}$, contribuindo assim para favorecer ainda mais $\mathrm{o}$ aquecimento.

Em síntese, a ação do homem tem levado à poluição do ar; destruído a camada de ozônio da estratosfera, que desempenha a função de reduzir a quantidade de radiação solar que atinge a superfície da Terra (troposfera); provocado o aumento das concentrações de gases de efeito estufa $\left(\mathrm{CO}_{2}, \mathrm{O}_{3}\right.$, metano, NOx) na troposfera, absorvendo maior quantidade de radiação solar e retendo calor; e tem reduzido a capacidade de captação de $\mathrm{CO}_{2}$ pela eliminação de áreas verdes e degradação da flora dos oceanos, levando assim às alterações climáticas como o aquecendo global, alterações pluviométricas, secas, aumentado a frequiência de catástrofes, além dos efeitos diretos na saúde. Estimativas ${ }^{4}$ atuais atribuem cerca de 800 mil óbitos à poluição do ar ambiental, 1,6 milhões à poluição do ar no interior dos domicílios e 154 mil óbitos 
às alterações climáticas; são cerca de 2,5 milhões de mortes evitáveis a cada ano e que, ao se manter os níveis atuais de emissões e destruição da natureza, tendem a aumentar. O Brasil, embora não esteja entre os principais poluidores e emissores de gases de efeito estufa também precisam tomar medidas drásticas que contribuam para reduzir a degradação do meio ambiente. Ampliar a rede de transportes coletivos, sobretudos nas regiões metropolitanas, desestimulando as emissões veiculares, eliminarem as injustificadas queimadas de cana-de-açúcar e de florestas, fruto da ganância e da busca do lucro fácil, e ampliar o já bem-sucedido esforço no desenvolvimento e uso de fontes não poluentes ou menos poluentes, como o biodiesel e álcool, são medidas possíveis de ser implantado a curto prazo e, assim, contribuir para a preservação da saúde e da vida em nosso Planeta.

\section{Sites:}

www.scielo.br

http://www.multiciencia.unicamp.br/art05_4.htm

http://www.agencia.fapesp.br/secao/4/divulgacao_cientifica.htm

http://www.cienciahoje.pt/index.php?oid=625

http://omnis.if.ufrj.br/ ifbib/divulga.htnl

http://www.eca.usp.br/njr/

http://www.cdcc.sc.usp.br/

http://stoa.usp.br/gkdivulga/weblog/

http://www.labjor.unicamp.br/

http://www.comciencia.br/comciencia/handler.php?section=8\&edicao $=37 \& i d 440$

NOTA: Sites que tenham "org” no link são mais confiáveis.

\section{ARTIGO 1}

\section{Células-tronco: a esperança para a medicina}

por Daniel

Frequentemente, no nosso dia-a-dia, nos deparamos pelos meios de comunicação, reportagens, matérias e discussões sobre pesquisas com células-tronco e a polêmica de divergência de ideias entre a Igreja e a ciência que esta têm causado... mas afinal, o que são células-tronco? 
Mas não há motivo para desespero e preocupação caso você ainda não saiba o que são células-tronco, até mesmo porque os cientistas ainda estão estudando como elas funcionam e o que fazem.

As células-tronco são divididas em dois grupos: as células-tronco embrionárias e as adultas. As células-tronco embrionárias são encontradas no embrião humano, já as adultas podem ser extraídas da medula óssea, na polpa dental de até mesmo no cordão umbilical.

As células-tronco servem principalmente para produzir outras células e para gerar novos tecidos no organismo que estão doentes, debilitados de destruídos. Nos cabe lembrar que os órgãos são formados de tecidos que, por sua vez, são formados por células. As células-tronco podem ser usadas para o tratamento do Mal de Alzheimer, Parkinson enfermidade incurável, mas tratável quando se usam células-tronco embrionárias ou adultas que ocasionalmente, diminuem os sintomas do mal em até $80 \%$ - traumatismo de medula espinhal, queimaduras, infartos, diabetes e doenças do coração - é válido ressaltar que ambas (embrionárias e adultas) são eficazes, mas as embrionárias tem um fator mais alto de regeneração de tecidos - Além disso tudo, pesquisas recentes com resultados animadores mostram que deficiência cardíaca; paralisia de membros; surdez; calvície; perda de ossos; derrames cerebrais e até mesmo o uso de próteses de silicone para os seios podem se tornar coisas do passado com o tratamento e uso das célulastronco.

Ainda, as células-tronco são divididas em vários tipos com base em sua potencialidade: 1 Totipotentes - podem produzir todas as células embrionárias e extra-embrionárias; 2 Pluripotentes - podem produzir todos os tipos celulares e tecidos do embrião; 3 Multipotentes - podem produzir várias linhagens de tecidos; 4 Oligopotentes - podem produzir células dentro de uma linhagem e 5 Unipotentes - produzem somente um único tipo celular maduro. As células embrionárias são pluripotentes porque uma única célula pode contribuir para a formação de todas as células e tecidos no organismo, exceto placenta.

\section{Ciência e Religião: os dois lados da moeda}

Mesmo com todos esse fatores sobre as células-tronco, há o outro lado da questão: a polêmica. Há quem condene as pesquisas, principalmente a comunidade religiosa católica. O motivo dessa discordância contra tais pesquisas é o uso de embriões para desenvolver técnicas e tratamentos com células-troco extraídas deles, pois aí, entra a questão da vida. Segundo a Igreja, a vida se inicia assim que o espermatozóide se 
encontra com o óvulo. A maioria dos cientistas discorda da Igreja, afirmando que a vida realmente começa no $2^{\circ}$ mês de gestação, quando começam as atividades cerebrais do feto. Até aí, nada confirmado pelos cientistas, pois acaba que alguns intelectuais discordaram disso, portanto, nada foi concretizado.

Os cientistas, ainda usam como argumento de defesa que os embriões usados para pesquisas, são aqueles que sobram em clínicas de fertilização ou que são defeituosos e iriam acabar no lixo, assim, podendo ser usados para dar saúde e um novo começo para quem realmente existe e tem vida, pois os embriões nunca estiveram em um útero nem nunca estarão, no caso de serem descartados das clínicas após 3 anos de congelamento. E mais, o seu uso nessas pesquisas só se dá quando há pleno consentimento do casal que os gerou. Não se deve, portanto, confundir o uso desses embriões com o aborto, algo totalmente diferente.

No Brasil, os tratamentos experimentais com células-tronco são feitos apenas em grandes hospitais e em pacientes que assinam um termo de consentimento e concordam em participar de estudos clínicos. Os principais centros de saúde do país que trabalham em pesquisas com células-tronco, são o Instituto do Coração - SP e o Instituto Nacional de Cardiologia em Laranjeiras - RJ, lembrando que os projetos somente vão para frente com a ajuda e investimentos do governo. Em países como a África do Sul, Alemanha, Austrália, Canadá, China, Holanda, Inglaterra, Japão, entre outros países da Europa, já é permitido o uso de células-tronco.

O mais importante de tudo que foi ressaltado, porém, é poder nos informar e tirar nossas próprias conclusões e opiniões sobre o assunto células-tronco e esclarecermos dúvidas. 


\section{ARTIGO 2}

\section{Solução social ou debate ético?}

por Carlos

Desde que o mundo existe, a ciência vem trabalhando a favor da população, principalmente no que se refere à pesquisa para a descoberta de curas de doenças.

A descoberta das células-tronco, que têm a capacidade de se auto-replicar e assim se diferenciarem vários tecidos do corpo, despontou como uma nova era cientifica, no qual seria a solução de muitos problemas relacionados as doenças, hoje, incuráveis.

Entretanto, o maior debate do mundo científico e de todos atualmente, não se baseia na eficácia das células-tronco, mas em como extraí-las, sem ferir os conceitos éticos e bioéticos remanescentes ao assunto.

As células-tronco podem ser extraídas de diversos tecidos humanos, tais como, medula óssea, sangue, fígado, cordão umbilical, placenta e etc.

As embrionárias só podem ser encontradas em embriões humanos e sua extração provoca a destruição dele.

A grande diferença entre eles são suas capacidades de se transformarem em tecidos humanos. As células-tronco embrionárias têm uma alta capacidade para se diferenciar em outros tecidos, entretanto as adultas já não possui toda a eficácia das embrionárias.

O grande dilema para os cientistas é criar células-tronco com a capacidade de se transformar em outros tecidos das embrionárias e a fácil obtenção das adultas. Para isso, eles trabalham arduamente nesse assunto, pois as resistências impostas, principalmente da igreja, em relação as células-tronco embrionárias ou não, é grande, pois segundo a igreja os embriões já caracterizam um ser com vida e portanto sua destruição se caracteriza como um homicídio.

Os cientistas defendem que a vida começa partir da formação do cérebro e da atividade do mesmo. E isso somente ocorre quando o embrião já não é mais caracterizado assim, pois já está em fase de feto.

Como se pode perceber, esse é um tema polêmico em que debatem frontalmente o conceito de vida proposto pela igreja e o conceito de vida proposto pelos cientistas.

O essencial do artigo é mostrar claramente os dois lados da discussão em pauta, para que o leitor, através de todas as informações passadas, possa desenvolver sua própria opinião sem ser persuadido pela opinião de ninguém, ou seja, de um terceiro. 


\section{ARTIGO 3}

\section{Células-tronco, crie a sua concepção}

por Sandra

Falar de assunto tão polemico não é considerada tarefa fácil, uma vez que os diversos de meio de comunicação não dão o devido valor ao assunto. Contudo, após algumas pesquisas e relacionar informações é possível escrever sobre o assunto...

Existem pessoas que por convicções religiosa ou mesmo por de fé na humanidade, considera o assunto uma total perda de tempo.

Entretanto, a matéria que estuda o assunto citado acima, a ciência, o considera de grande importância á fím de uma construção de novos pensamentos e possibilidades de melhora da qualidade de vida.Com isso agregou-se o estudo mais aprofundado de células tronco como "SALVADOR DA PÁTRIA".

Atualmente, sabe-se que células tronco são todas aquelas que são retiradas do embrião, depois de 14 dias ou duas semanas, após a fecundação do óvulo, tais células são classificadas de acordo com a sua função no organismo sendo elas:

1. Totipotentes: são células-tronco que conseguem se diferenciar em todos os 216 tecidos que formam o corpo humano, inclusive placenta e anexos embrionários. É o caso de Zigoto (óvulo fertilizado);

2. Pluripotentes; são as que conseguem se diferenciar nos tecidos provenientes dos 3 folhetos embrionários (ectoderme, endoderme e mesoderme). Ex. Células da Massa Interna de um Embrião de 5-6 dias;

3. Multipotentes: capazes de originar diversos tecidos, porém não se sabe bem a qual;

4. Oligopotentes: capazes de originar pouco tecidos, retirados de células adultas;

5. Unipotentes: possui a produção mais restringida, podendo ser possível a produção de um tecido.

As duvidas relacionadas, ao assunto ainda estão longe de encontrar uma resposta que venha valer de verdade absoluta. Por sua vez, sabe-se que o assunto células tronco, ainda gera uma grande polemica.

Os religiosos costumam chamá-lo de "BINEAR DE DEUS", já para os cientistas acreditam estar apenas fazendo um bem para a humanidade, sendo suas descobertas de grande importância á todos, até os que não acreditam e aqueles que se precipitaram em julgar o assunto 
Enfim, a discussão está proposta, se tais descobertas são boas ou ruins?Ninguém sabe, mas isto é um assunto que de diversas formas será atacado,defendido e julgado. Crie você a sua concepção do assunto. 


\section{ARTIGO 4}

\section{Células-tronco}

por Ana

Nos últimos anos o assunto "Células-tronco" tem sido muito debatido e é freqüentemente exposto na mídia. Como a maioria das grandes novidades, está área está sendo superestimada se for considerada atual, entretanto na há duvidas de que suas potencialidades são enormes, e pode se esperar um no tipo de medicina a partir da evolução dessas pesquisas. Na verdade, o que se têm hoje é uma série de perspectivas e os resultados obtidos nas experiências em animais de pequeno porte não podem, ainda, ser extrapolados para a espécie humana. Experiências clinicas têm, entretanto, mostrado resultados alentadores.

Os diferentes tecidos são formados por células com características diversas. Por exemplo: o tecido muscular está constituído por células especializadas em contração, os miócitos. O tecido nervoso está constituído por neurônios e assim por diante.

Quando uma das primeiras células do embrião sofre uma mitose e se divide, as duas células resultantes têm a mesma constituição genética e as mesmas características. A embriogênese progride com a continua multiplicação das células, aumentando o numero das mesmas e o tamanho do embrião.

O interessante é que dentro da célula mais primitiva, o zigoto, existe informação suficiente para que, na medida em que essas células forem se dividindo, aos poucos ocorra uma diferenciação, originando diferentes linhagens que formarão diferentes tecidos como muscular, ósseo, nervoso, etc.

Após a fecundação, a célula formada é denominada zigoto. O zigoto é uma célula totipotencial, ou seja, tem a capacidade de originar todo o individuo, com a sua complexa estrutura diferenciada.

Depois das primeiras divisões celulares, as células se separarem, a continuidade da origem dara gêmeos idênticos ou univitelineos,provocando sua totiponcialidade.

No decorrer da embriogênese na medida em que ocorrem sucessivas mitoses vai se formando um conjunto denominado blastócito.

O agrupamento celular central deste conglomerado apresenta células, e por isto são consideradas pluripotencias. 
A diferença essencial entre uma célula totipotencial e outra pluripotencial é o fato de que a primeira (totipotencial) poderia até originar um novo individuo, enquanto que a segunda (pluripotencial) não teria essa capacidade. Ambas, têm a capacidade de gerar qualquer célula. $\mathrm{O}$ uso de células-tronco adultas seria definido como retirada de um grupo de células-tronco de determinada região do organismo de um paciente e seu aproveitamento no próprio indivíduo. A medula óssea do individuo adulto é uma zona extremamente usada como fonte de células-tronco transplantadas para o mesmo individuo. Quanto ao uso de células- tronco embrionárias discussões podem entrar em cogitação. Nesta situação, a retirada das células é realizada em embriões com poucos dias de desenvolvimento, esta retirada é feita na maioria das vezes com o sacrifício do embrião, o que estabelece um dilema ético. Grande discussões tem sido realizadas sobre este dilema. Grupos religiosos de especialistas em ética e de cientistas estão há bastante tempo discutindo de maneira mais ou menos veemente este problema.O sacrifício de embrião doador destas células totipotenciais, ou mesmo pluripotencias, cria uma situação extremante delicada e de difícil consenso. 


\section{ARTIGO 5}

\section{Células-tronco: A terapia curadora e a questão antiética}

por Júlia

Nos últimos anos, o assunto "células-tronco" tem sido debatido e freqüentemente exposto na mídia.

Especialistas de todas as áreas concordam que a ciência está a serviço da população, principalmente quando se trata de pesquisa pra a descoberta da cura de doenças que afetam milhares de pessoas.

As células-tronco são células primitivas, produzidas durante o desenvolvimento do organismo e que dão origem a outros tipos de células. É um tipo de célula que pode se diferenciar e constituir diferentes tecidos no organismo. Esta é uma capacidade especial porque as demais células geralmente só podem fazer parte de um tecido específico, por exemplo, células da pele só podem constituir a pele.

As células-tronco podem ser tanto embrionárias como adultas: as células-tronco embrionárias são aquelas encontradas em embriões. Essas células têm capacidade de se transformar em praticamente qualquer célula do corpo. São chamadas pluripotente. É essa capacidade que permite que um embrião se transforme em um corpo totalmente formado.

As células-tronco de adultos são mais especializadas que as embrionárias e dão origem a tipos específicos de células. São chamadas multipotentes. Algumas pesquisas sugerem que as células-tronco adultas podem se transformar em tipos muito variados de células. As células-tronco são classificadas em cinco tipos:

- Totipotentes: são células capazes todas as células embrionárias e extra-embrionárias

- Pluripotentes: São células capazes de produzir todos os tipos celulares do embrião.

- Multipotentes; são células capazes de originar diversos tecidos.

- Oligopotentes: são células capazes de originar poucos tecidos do corpo.

- Unipotentes:são células capazes de originar um único tecido do corpo.

Essas células têm a função de ajudar no reparo de uma lesão. Se a medicina conseguir controlar a desenvolvimento dessas células, elas poderão ser utilizadas para reparar tecidos e tratar enfermidades até hoje incuráveis. 
O benefício que as células-tronco podem proporcionar segundo médicos e cientistas é indiscutível, gerando soluções para a cura de doenças que desafiam a medicina.

Para os defensores do uso de células-tronco embrionárias, o embrião não é um ser humano, é apenas um conjunto de células do qual vai originar um ser humano.

A Igreja tem acompanhado com muita atenção tais avanços científicos e continua a reafirmar sua postura em defesa da vida. Em relação as células-tronco,a Igreja tem se posicionado contra o uso de células embrionárias, visto que, com o processo de obtenção de tais células, o embrião é destruído.

O que a Igreja deseja não é impedir os avanços científicos, mas lembrar a toda a sociedade que a ciência deve continuar seus progressos, porém sem se esquecer das questões éticas.

Enfim, podemos perceber que há certos conflitos entre a ciência e a religião, há o lado a favor e o contra.

Diante de tudo isso, o importante é estarmos informado sobre o assunto, analisando os dois lados e chegando a uma conclusão concreta de acordo com que cada um acredita! 


\section{ARTIGO 6}

\section{Célula-tronco Embrionárias: uma esperança polêmica}

por Paula

Célula-tronco são células capazes de se reproduzir e gerar diversos tipos de células. Essas células podem ser: adultas, quando são retiradas de tecidos (basicamente da medula óssea e do cordão umbilical) e originam apenas determinados tipos de tecidos, ou embrionárias, quando retiradas de embriões humanos.

As células-tronco embrionárias são consideradas uma grande promessa para a medicina, pois são de capazes de gerar qualquer outro tipo de células. Células produtoras de insulina, células do sistema imunológico, células cardíacas, hemácias, neurônios e ossos, são algumas células obtidas até hoje a partir de células-tronco embrionárias.

A versatilidade destas células trouxe esperanças para muitas pessoas que sofrem de patologias graves como fibrose cística, esclerose múltipla, distrofia muscular, anemia falciforme, entre outras doenças consideradas praticamente incuráveis.

No Brasil o Supremo Tribunal Federal permitiu em 2008 a realização de estudos em células-tronco retiradas de embriões congelados há pelo menos três anos em clínicas de reprodução humana, desde que houvesse consentimento dos pais. Até então estes estudos estavam prejudicados, pois poucos pesquisadores arriscavam-se a trabalhar com células embrionárias importadas de outros países.

Agora coma permissão definitiva os pesquisadores estão analisando as características, o funcionamento e as formas de extrair e cultivar as células embrionárias.Muitas pesquisas estão sendo desenvolvidas para descobrir o potencial das células-tronco embrionárias, os pesquisadores querem saber se essas células são eficientes para tratar lesões substituindo estrutura atingidas.

Pesquisas realizadas nos Estados Unidos apresentam resultados impressionantes, em estudos com ratos foi possível reduzir danos associados a acidente vascular cerebral (derrame), o que comprova o potencial que essas células têm para o tratamento para doenças complexas, isso aumenta as esperanças de que as células embrionárias possam ser usadas para tratamentos em larga escala.

Devido a grande capacidade de produzir qualquer tipo de célula, as células-tronco embrionárias tornaram-se muito atraentes para a comunidade cientifica.Mas há um serie de embargos para a utilização destas células embrionárias para a pesquisa, não há um 
consenso em relação ao uso, em alguns países o uso é totalmente irrestrito permitindo inclusive a criação de embriões através de transferência de núcleo, em outros os estudos ainda não foram liberados.

A polêmica em torno da manipulação destas células está relacionada ao fato de que a retirada da célula-tronco do embrião resulta na perda do mesmo. Entre os argumentos que condenam essa prática estão os que se apóiam em valores religiosos considerando o embrião um ser vivo independente do seu tempo de existência e, os que se baseiam nos códigos morais e consideram essas pesquisas inconstitucionais argumentando que o uso de embriões fere o direito à vida, garantido pela Constituição.

Apesar de tudo o uso das células-tronco embrionárias para o tratamento terapêutico de doenças é com certeza um passo revolucionário para a medicina; para os portadores de doenças representa uma possibilidade de que no futuro seus sofrimentos possam ser amenizados ou até mesmo curados.

Os prováveis resultados da eficácia das células embrionárias no tratamento de varias doenças é uma animadora perspectiva para milhares de pacientes que veem agora uma possibilidade de terem as mesmas condições de vida da maioria da população, assim estas células passaram a se consideradas uma formidável fonte de esperança e saúde e vida. 


\section{Diário de reuniões dos alunos (“diário de bordo")}

$\rightarrow 25 / 08 / 2009-12 \mathrm{~h} 00$

$\underline{\text { Reunião para definir os passos do trabalho }}$

Estavam presentes:

1. Mônica

2. Simone

3. Pedro

4. Andressa

5. Soraia

Nesta reunião definimos o que seria feito durante o nosso trabalho e como o faríamos.

Decidimos que seria feita uma cartilha de apresentação do projeto e com os passos para se fazer um artigo.

\section{Conteúdo da Cartilha}

- Apresentação;

- Passo-a-passo de como elaborar um artigo;

- Sites;

- Nossos artigos;

- E-mails e telefones.

Foi também, decidido por nós que entregaríamos autorizações para os alunos para que seus pais estivessem cientes do projeto e da participação de seus filhos.

Faremos relatórios de cada reunião e construiremos um diário de bordo, para colocar todas as informações e o passo-a-passo do trabalho desenvolvido.

Foi elaborado um calendário para definirmos datas tanto para nós quanto para os alunos. 


\section{$\underline{\text { Calendário }}$}

26/08 - Passar informações do projeto aos alunos envolvidos.

\begin{tabular}{|c|c|c|c|c|c|c|}
\hline \multicolumn{7}{|c|}{ Setembro } \\
\hline DOM & SEG & TER & QUA & QUI & SEX & SAB \\
\hline & & 01 & 02 & 03 & $\begin{array}{l} \\
\text { Entrega das } \\
\text { apostilas }\end{array}$ & 05 \\
\hline 06 & $\begin{array}{ll} & 07 \\
\text { Feriado } & \end{array}$ & $\begin{array}{ll} & 08 \\
\text { Reunião } & \\
\text { com } & \text { os } \\
\text { alunos } & \end{array}$ & 09 & 10 & 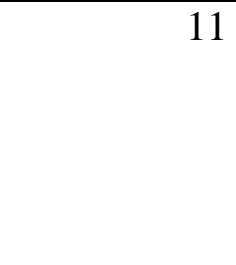 & 12 \\
\hline 13 & 14 & 15 & 16 & 17 & $\begin{array}{r}18 \\
\text { Recebiment } \\
\text { o dos artigos }\end{array}$ & 19 \\
\hline 20 & 21 & 22 & 23 & 24 & $\begin{array}{l}25 \\
\text { Debate/reun } \\
\text { ião }\end{array}$ & 26 \\
\hline 27 & 28 & 29 & $\begin{array}{ll} & 30 \\
\text { Entrega } & \text { do } \\
\text { trabalho } & \end{array}$ & & & \\
\hline
\end{tabular}

$\underline{\text { Alunos que farão parte do trabalho }}$

- Júlia

- Sandra

- Carlos

- Ana

- Paula

- Daniel

04/09 - Reunião com os alunos para a entrega das apostilas.

Houve uma breve explicação no que se refere a divulgação científica. Mostrou-se a sua importância para todos da sociedade e o papel que ela desempenha. 
08/09 - Reunião com os alunos, na qual apresentamos o projeto:

- Apresentação do projeto;

- Leitura do texto pelos alunos;

- Bate-papo;

- Explicação do assunto;

- Dúvidas.

Houve uma boa interação com os alunos, onde a apostila foi apresentada e eles participaram da leitura.

O tema Divulgação Científica, foi mais uma vez frisado, e os alunos ficaram mais a vontade para opinar e tirar dúvidas, gerando um verdadeiro "bate-papo".

Chegamos a um tema e a tarefa foi confiada aos alunos, sendo que eles poderiam estar entrando em contato conosco para esclarecer qualquer eventual dúvida.

Tarefa: Escrever um artigo de divulgação.

Tema: Células-Tronco

Para explicarmos como "funciona" a estrutura do artigo, usamos exemplos, como os nossos próprios artigos. Também concedemos algumas bibliografias que poderiam consultar.

$\rightarrow 18 / 09$ - Recebemos os artigos e Debate sobre o tema.

Esta foi a data da entrega dos artigos. Os alunos deram a sua opinião sobre o projeto e também contaram como foi a experiência de redigir um artigo.

O tema Células-tronco também foi discutido, onde os alunos mostraram ter uma opinião formada sobre o assunto.

Os diversos meios de divulgação cientifica também foram comentados, seja ele por internet, jornais , revistas, televisão, filmes, etc.

Por fim, os alunos terminaram o projeto entendendo a importância da ciência na sociedade e a importância de que ela chegue a todos de forma coerente e concisa.

$\rightarrow 25 / 09$ - Entrega da correção dos alunos e fotos.

Após lermos e analisarmos os artigos que foram entregues, fizemos a correção, levando em conta alguns aspectos como:

- Ortografia;

- Estrutura;

- Coerência e coesão. 
Entre outros.

Em sua totalidade os artigos ficaram bons.

Foram apontados os pontos negativos e positivos dos artigos.

Neste mesmo dia tiramos fotos com todos os alunos que participaram do projeto.

28/09 - Finalização do relatório.

O grupo se reuniu e o relatório foi finalizado de acordo com as reuniões que foram realizadas e aqui relatadas. 


\section{Exemplo de autorização}

SECRETARIA DO ESTADO DE SÃO PAULO

COORD. DE ENSINO DA REG. METROP. DA GDE. SÃO PAULO

DIRETORIA DE ENSINO DE CARAPICUIBA

ESCOLA ESTADUAL "PROFa. HADLA FERES"

R. Bandeirantes, 80 - Vila Dirce - CEP 06335-030 - Fone/FAX: (011) 4187-3761 Carapicuíba - São Paulo

\section{TERMO DE CONSENTIMENTO}

Pelo presente instrumento que atende as exigências legais, o(s) Senhor(a) RG: responsável pelo adolescente matriculado na __ série do ensino , na

E.E.”PROFa. Hadla Feres“, no presente ano letivo, AUTORIZO o uso da imagem e do som do mesmo para os devidos fins de divulgação científica*, referente ao trabalho de pesquisa do Programa de Pré-iniciação Científica, promovido pela Secretaria de Estado da Educação em parceria com a Universidade de São Paulo.

*Entende-se por divulgação científica a apresentação e uso de imagens, sons, falas e objetos confeccionados pelos envolvidos no estudo, compondo material analisado à luz de estudos científicos, devidamente justificados pelo(s) autor(es) e orientador(es) da pesquisa em questão.

Carapicuíba, de de 2009 
Relatório final elaborado pelos alunos

Pré Iniciação Científica da USP

Faculdade de Educação

E.E. Profa. Hadla Feres

Comunicação Científica na sala de aula de ciência da escola média

\author{
Grupo: \\ Mônica \\ Simone \\ Andressa \\ Soraia \\ Carla \\ Pedro
}

Professor: José João de Alencar

Professor Orientador: $\operatorname{Prof}^{\circ} \operatorname{Dr}^{\circ}$ Aguinaldo Arroio e

Professora: Luciane Baião

\title{
Carapicuíba
}

2009 


\section{Introdução:}

Depois de realizadas várias atividades de pesquisa e confecção de artigos, nós alunos do Pré-Iniciação Científica da USP, recebemos a missão de passar nossos conhecimentos e experiências com divulgação científica para outros alunos da rede de ensino.

A fim de que os mesmo tivessem um contato maior com ciência entendessem o que é divulgação.

Foram selecionados seis alunos do ensino médio, a partir do $1^{\circ}$ ao $3^{\circ}$ ano, onde elaboraram seus próprios artigos de divulgação científica.

Em suma, uma experiência de aprendizagem e conhecimento.

\section{Descrição das Atividades}

13/08 - Tivemos conhecimento da nova e última tarefa.

25/08 - Primeira reunião para definir os passos do trabalho.

Estavam presentes:

1. Mônica

2. Simone

3. Pedro

4. Andressa

5. Soraia

Nesta reunião definimos o que seria feito durante o nosso trabalho e como faríamos.

Decidimos que seria feita uma cartilha de apresentação do projeto e com os passos para se fazer um artigo.

Conteúdo da Cartilha:

- Apresentação;

- Passo-a-passo de como elaborar um artigo;

- Sites;

- Nossos artigos;

- e-mails e telefones.

Foi também, decidido por nós que entregaríamos autorizações para os alunos para que seus pais estivessem cientes do projeto e da participação de seus filhos.

Faremos relatórios de cada reunião e construiremos um diário de bordo, para colocar todas as informações e o passo-a-passo do trabalho desenvolvido.

04/09 - Reunião com os alunos para a entrega das Apostilas.

08/09 - Reunião com os alunos, na qual apresentaremos o projeto: 
- Apresentação do projeto;

- Leitura do texto pelos alunos;

- Bate-papo;

- Explicação do assunto;

- Dúvidas.

Tarefa: Escrever um artigo de divulgação.

Tema: Células-Tronco.

18/09 - Recebemos os artigos e debate sobre o tema.

25/09 - Entregamos a correção aos alunos e tiramos fotos.

28/09 - Finalização do relatório

\title{
Resultados:
}

Foram textos bem elaborados, claros e objetivos.

\section{Aluno: Carlos}

O texto do aluno Carlos, esta muito bem elaborado. Ele disserta bem e deixam claro e conciso seus argumentos. A estrutura segue a linha de divulgação cientifica e informa bem. Mostra de uma forma ampla o tema e sua ortografia é muito boa. O titulo foi muito bem empregado e chama a atenção do leitor. Houve dois erros de concordância nominal, creio que por falta de atenção.Também houve erro de virgula que deixou um dos parágrafos confuso. O aluno não citou fontes bibliográficas. Mas em sua totalidade é um texto muito bom.

Mônica

\begin{abstract}
Aluna: Júlia
A aluna Júlia escreve muito bem. Seu texto aparentemente não apresenta erros ortográficos e nem erros de concordância. O texto redigido por ela é claro no que diz respeito ao tema, entretanto o assunto ressaltado por ela no titulo é colocado em discussão, não foi bem desenvolvido de maneira enfática. O tema proposto foi célulastronco e ela conseguiu explica de maneira simples e concisão mesmo. A aluna em relação ao projeto se demonstrou interessada e bastante envolvida. Retirou algumas duvidas no decorrer do período que teve para redigir seu artigo, e eu ajudei no que foi preciso.
\end{abstract}


Suas principais duvidas foram em relação a estrutura do artigo e a concordância em relação aos parágrafos iniciais. Acredito que ela tenha tido um ótimo desempenho e que de fato aprendeu a escrever um bom artigo de divulgação cientifica.

Simone

\begin{abstract}
Aluna: Ana
Um artigo muito bom, com apenas dois erros de grafia que podem ser facilmente corrigidos.

Lendo esse artigo dá para entender muito bem o que é células-tronco, porem ficou muito vago o principal assunto para a divulgação: religião x Ciências.

$\mathrm{Na}$ minha forma de analisar, cheguei a conclusão que a aluna atingiu as expectativas, pois para um primeiro artigo ela foi muito bem e para fazê-lo utilizou todos os passos que lhe foram passados.
\end{abstract}

Andressa

\begin{abstract}
Aluno: Daniel
Alguns erros de concordância

Utilização excessiva da $1^{\circ}$ pessoa do plural, o que não se pode dizer que esteja errado, porem era desnecessário sendo que o autor, tendo ele feito suas pesquisas, não precisa divulgar a ciência a si e a população, mas só a população. Pouca, mas relevante, utilização de advérbios desnecessários. Informação incorreta: o embrião só começa a desenvolver o sistema nervoso a partir de 14 dias da fecundação, ou seja, duas semanas e não dois meses. Sem apontar fontes de consulta.

Soube passar a informação de forma clara, sem utilizar um vocabulário difícil, objetivo e sem fugir de seu assunto principal. No inicio o aluno havia me dito que não sabia nada sobre células-tronco e que se pudesse evitar trabalhar esse assunto seria melhor, mas ao conhecer melhor o assunto ele passou a se interessar. Acho que isso é divulgação cientifica: passar a informação de forma que as pessoas gostem de ciências.
\end{abstract}

Pedro

\footnotetext{
Aluna: Paula

$\mathrm{O}$ artigo redigido pela aluna ficou excelente, abordando vários assuntos relacionados a células-tronco, mostrando a polemica que envolve as pesquisas com as células, e uma
} 
das características mais importante, ela conseguiu abordar vários assuntos sem sair do foco.

O titulo de seu artigo se encaixou perfeitamente ao assunto. A aluna usou alguns termos na qual deveria ter explicado melhor, pois esses podem acabar dificultando o entendimento do leitor na hora da leitura. Ela também não citou fontes de pesquisas. Durante o tempo que ela teve para redigir seu artigo, conforme ela foi redigindo ela me mostrava para ver como estava indo. Que por sinal me surpreendeu, pois por ser o primeiro artigo ela estava muito bem.

Essas são as minhas observações tirando isso à aluna Paula escreve muito!

Soraia

\section{Aluna: Sandra}

A aluna procurou escrever de forma clara e objetiva, destacando os seguintes pontos fundamentais do seu artigo sendo:

$1^{\circ}$ Informações corretas e incorretas em certos pontos;

$2^{\circ}$ Parágrafo Incompleto;

$3^{\circ}$ Ótimo desenvolvimento do âmbito textual entre células embrionárias e adultas;

$4^{\circ}$ Ao classificar as células, verifica-se a falta de organização entre as palavras;

$5^{\circ}$ soube descrever a grande polemica;

$6^{\circ}$ Não colocou as fontes;

Em relação ao $1^{\circ}$ e $2^{\circ}$ termo, percebe-se a grande quantidade de pesquisas e a falta de distinguir o certo do errado, por isso um parágrafo incompleto.

O $3^{\circ}$ e $4^{\circ}$ termo estão excelentes, com exceção de que devido ao grande número de informações, faltou concordância entre as palavras.

Devido, não saber as fontes utilizadas pela aluna, não posso afirmar que tudo esta certo ou errado, porem acredito ter passado os conhecimentos adquiridos para a aluna.

Carla

\section{Conclusão:}

A importância da Divulgação Cientifica, se dá pelo fato das pessoas não se interessarem pelo assunto e buscar maiores informações.

As pessoas não gostam daquilo que não conhecem, isso acarreta no desinteresse pelos assuntos científicos que fazem parte do dia-a-dia na nossa sociedade. 
Dessa forma, a divulgação cientifica se mostra de demasiada importância, pois as pessoas se mantem atualizadas e bem informadas, podemos desenvolver uma opinião própria sobre determinado assunto.

Os artigos elaborados pelos alunos sem sua totalidade forma bons. No inicio estavam inseguros e com algumas duvidas (o que é normal), entretanto mostrando-se concisos e coerentes ao redigirem seus respectivos artigos. Enfim, conseguimos transmitir os conhecimentos no que se refere à divulgação cientifica, o que foi muito gratificante. O objetivo maior foi alcançado. 